\title{
ॠUSGS
}

science for a changing world

Prepared in cooperation with the Nebraska Department of Natural Resources; and the Upper Elkhorn, Lower Elkhorn, Upper Loup, Lower Loup, Middle Niobrara, Lower Niobrara, Lewis and Clark, and Lower Platte North Natural Resources Districts; and the University of NebraskaLincoln Conservation and Survey Division

Hydrostratigraphic Interpretation of Test-Hole and Surface Geophysical Data, Elkhorn and Loup River Basins, Nebraska, 8 ? 2008 to 2011

1.

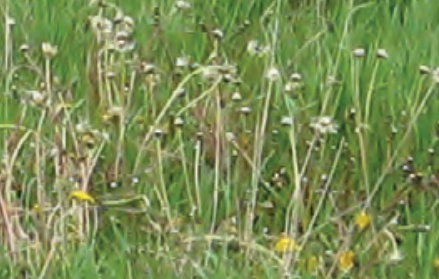

W

,

Open-File Beport?2042 1227 .

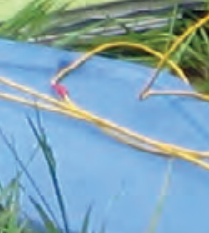


Front cover. Time-domain electromagnetic data collection in the Lower Elkhorn Natural Resources District, 2011. 


\section{Hydrostratigraphic Interpretation of Test- Hole and Surface Geophysical Data, Elkhorn and Loup River Basins, Nebraska, 2008 to 2011}

By Christopher M. Hobza, Paul A. Bedrosian, and Benjamin R. Bloss

Prepared in cooperation with the Nebraska Department of Natural Resources; and the Upper Elkhorn, Lower Elkhorn, Upper Loup, Lower Loup, Middle Niobrara, Lower Niobrara, Lewis and Clark, and Lower Platte North Natural Resources Districts; and the University of Nebraska-Lincoln Conservation and Survey Division

Open-File Report 2012-1227 


\title{
U.S. Department of the Interior \\ KEN SALAZAR, Secretary \\ U.S. Geological Survey \\ Marcia K. McNutt, Director
}

\author{
U.S. Geological Survey, Reston, Virginia: 2012
}

For more information on the USGS - the Federal source for science about the Earth, its natural and living resources, natural hazards, and the environment, visit http://www.usgs.gov or call 1-888-ASK-USGS.

For an overview of USGS information products, including maps, imagery, and publications, visit http://www.usgs.gov/pubprod

To order this and other USGS information products, visit http://store.usgs.gov

Any use of trade, firm, or product names is for descriptive purposes only and does not imply endorsement by the U.S. Government.

Although this information product, for the most part, is in the public domain, it also may contain copyrighted materials as noted in the text. Permission to reproduce copyrighted items must be secured from the copyright owner.

Suggested citation:

Hobza, C.M., Bedrosian, P.A., and Bloss, B.R., 2012, Hydrostratigraphic interpretation of test-hole and surface geophysical data, Elkhorn and Loup River Basins, Nebraska, 2008 to 2011: U.S. Geological Survey Open-File Report 2012-1227, $95 \mathrm{p}$. 


\section{Contents}

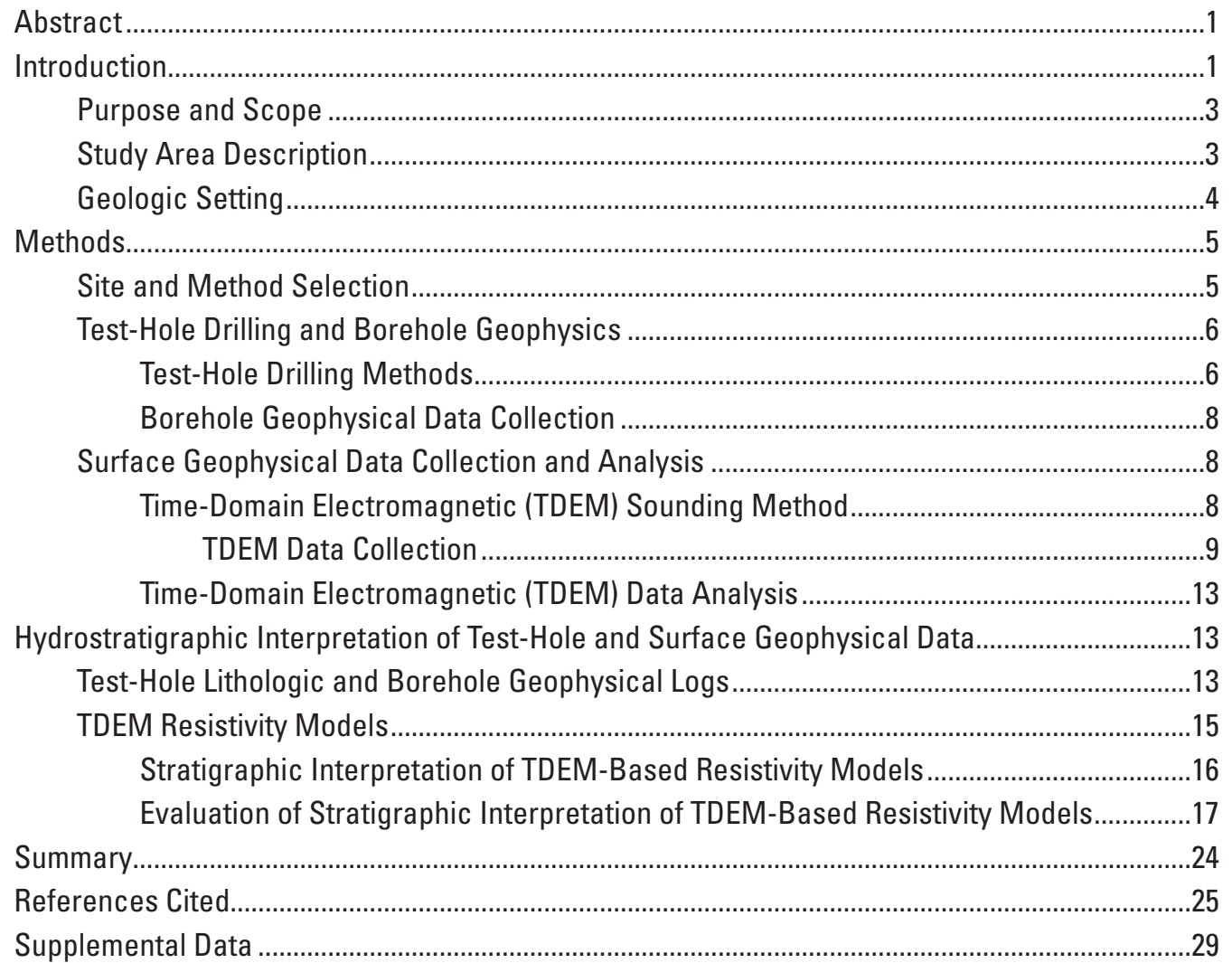

\section{Figures}

1. Map showing location of the Elkhorn-Loup Model study area and Natural Resources Districts, Nebraska..................................................................................

2. Map showing location of test holes and time-domain electromagnetic soundings, Elkhorn-Loup Model study area, 2008-2011 ................................................7

3. Composite of generalized lithologic description and geophysical logs for test hole 1-LL-10, Custer County, Nebraska .............................................................................14

4. Composite of generalized lithologic description and geophysical logs for test hole 2-LL-10, Custer County, Nebraska ………………….................................................30

5. Composite of generalized lithologic description and geophysical logs for test hole 3-LL-10, Custer County, Nebraska ............................................................................31

6. Composite of generalized lithologic description and geophysical logs for test hole 4-LL-10, Custer County, Nebraska ……………...........................................................32

7. Composite of generalized lithologic description and geophysical logs for test hole 6-LL-10, Custer County, Nebraska .............................................................................33

8. Composite of generalized lithologic description and geophysical logs for test hole 7-LL-10, Custer County, Nebraska. 
9. Graphs showing relations between $A$, central-loop resistivity, out-of-loop vertical magnetic field, and elapsed time after primary current turnoff; and $B$, depth below land surface and subsurface resistivity modeled from timedomain electromagnetic sounding for site UE11

10. Graphs showing relations between $A$, central-loop resistivity, out-of-loop vertical magnetic field and time elapsed after primary current turnoff; and $B$, depth below land surface and subsurface resistivity modeled from timedomain electromagnetic sounding for sites CGG1 and CGG2.

11. Graphs showing relations between $A$, central-loop resistivity, out-of-loop vertical magnetic field and time elapsed after primary current turnoff; and $B$, depth below land surface and subsurface resistivity modeled from timedomain electromagnetic sounding for sites CGG3 and CGG4.

12. Graphs showing relations between $A$, central-loop resistivity and time elapsed after primary current turnoff; and $B$, depth below land surface and subsurface resistivity modeled from time-domain electromagnetic sounding for sites CGG5 and CGG6.

13. Graphs showing relations between $A$, central-loop resistivity and time elapsed after primary current turnoff; and $B$, depth below land surface and subsurface resistivity modeled from time-domain electromagnetic sounding for sites CGG7 and CGG8.

14. Graphs showing relations between $A$, central-loop resistivity and time elapsed after primary current turnoff; and $B$, depth below land surface and subsurface resistivity modeled from time-domain electromagnetic sounding for sites CGG9 and CGG10.

15. Graphs showing relations between $A$, central-loop resistivity and time elapsed after primary current turnoff; and $B$, depth below land surface and subsurface resistivity modeled from time-domain electromagnetic sounding for sites CGG11 and CGG12

16. Graphs showing relations between $A$, central-loop resistivity and time elapsed after primary current turnoff; and $B$, depth below land surface and subsurface resistivity modeled from time-domain electromagnetic sounding for sites CGG13 and CGG14

17. Graphs showing relations between $A$, central-loop resistivity and time elapsed after primary current turnoff; and $B$, depth below land surface and subsurface resistivity modeled from time-domain electromagnetic sounding for sites CGG15 and LL27

18. Graphs showing relations between $A$, central-loop resistivity, out-of-loop vertical magnetic field, and time elapsed after primary current turnoff; and $B$, depth below land surface and subsurface resistivity modeled from timedomain electromagnetic sounding for sites CN1 and CN2

19. Graphs showing relations between $A$, central-loop resistivity, out-of-loop vertical magnetic field, and time elapsed after primary current turnoff; and $B$, depth below land surface and subsurface resistivity modeled from timedomain electromagnetic sounding for sites CN3 and CN4

20. Graphs showing relations between $A$, central-loop resistivity, out-of-loop vertical magnetic field, and time elapsed after primary current turnoff; and $B$, depth below land surface and subsurface resistivity modeled from timedomain electromagnetic sounding for sites CN5 and CN6. 
21. Graphs showing relations between $A$, central-loop resistivity, out-of-loop vertical magnetic field, and time elapsed after primary current turnoff; and $B$, depth below land surface and subsurface resistivity modeled from timedomain electromagnetic sounding for sites CN8 and CN9.

22. Graphs showing relations between $A$, central-loop resistivity, out-of-loop vertical magnetic field, and time elapsed after primary current turnoff; and $B$, depth below land surface and subsurface resistivity modeled from timedomain electromagnetic sounding for sites LL1 and LL2.

23. Graphs showing relations between $A$, central-loop resistivity, out-of-loop vertical magnetic field, and time elapsed after primary current turnoff; and $B$, depth below land surface and subsurface resistivity modeled from timedomain electromagnetic sounding for sites LL3 and LL4.

24. Graphs showing relations between $A$, central-loop resistivity, out-of-loop vertical magnetic field, and time elapsed after primary current turnoff; and $B$, depth below land surface and subsurface resistivity modeled from timedomain electromagnetic sounding for sites LL5 and LL6.

25. Graphs showing relations between $A$, central-loop resistivity, out-of-loop vertical magnetic field, and time elapsed after primary current turnoff; and $B$, depth below land surface and subsurface resistivity modeled from timedomain electromagnetic sounding for sites LL7 and LL8.

26. Graphs showing relations between $A$, central-loop resistivity, out-of-loop vertical magnetic field, and time elapsed after primary current turnoff; and $B$, depth below land surface and subsurface resistivity modeled from timedomain electromagnetic sounding for sites LL9 and LL10.

27. Graphs showing relations between $A$, central-loop resistivity and time elapsed after primary current turnoff; and $B$, depth below land surface and subsurface resistivity modeled from time-domain electromagnetic sounding for sites LL11 and LL12.

28. Graphs showing relations between $A$, central-loop resistivity, out-of-loop vertical magnetic field, and time elapsed after primary current turnoff; and $B$, depth below land surface and subsurface resistivity modeled from time-domain electromagnetic sounding for sites LL13 and LL14

29. Graphs showing relations between $A$, central-loop resistivity and time elapsed after primary current turnoff; and $B$, depth below land surface and subsurface resistivity modeled from time-domain electromagnetic sounding for sites LL15 and LL16.

30. Graphs showing relations between $A$, central-loop resistivity, out-of-loop vertical magnetic field, and time elapsed after primary current turnoff; and $B$, depth below land surface and subsurface resistivity modeled from timedomain electromagnetic sounding for sites LL17 and LL18.

31. Graphs showing relations between $A$, central-loop resistivity, out-of-loop vertical magnetic field, and time elapsed after primary current turnoff; and $B$, depth below land surface and subsurface resistivity modeled from timedomain electromagnetic sounding for sites LL19 and LL20..

32. Graphs showing relations between $A$, central-loop resistivity, out-of-loop vertical magnetic field, and time elapsed after primary current turnoff; and $B$, depth below land surface and subsurface resistivity modeled from timedomain electromagnetic sounding for sites LL21 and LL22 
33. Graphs showing relations between $A$, central-loop resistivity, out-of-loop vertical magnetic field, and time elapsed after primary current turnoff; and $B$, depth below land surface and subsurface resistivity modeled from timedomain electromagnetic sounding for sites LL23 and LL24.

34. Graphs showing relations between $A$, central-loop resistivity, out-of-loop vertical magnetic field, and time elapsed after primary current turnoff; and $B$, depth below land surface and subsurface resistivity modeled from timedomain electromagnetic sounding for sites LL25 and LL26.

35. Graphs showing relations between $A$, central-loop resistivity and time elapsed after primary current turnoff; and $B$, depth below land surface and subsurface resistivity modeled from time-domain electromagnetic sounding for sites SH1 and $\mathrm{SH} 2$.

36. Graphs showing relations between $A$, central-loop resistivity and time elapsed after primary current turnoff; and $B$, depth below land surface and subsurface resistivity modeled from time-domain electromagnetic sounding for sites $\mathrm{SH} 3$ and $\mathrm{SH} 4$.

37. Graphs showing relations between $A$, central-loop resistivity and time elapsed after primary current turnoff; and $B$, depth below land surface and subsurface resistivity modeled from time-domain electromagnetic sounding for sites SH5 and SH6.

38. Graphs showing relations between $A$, central-loop resistivity and time elapsed after primary current turnoff; and $B$, depth below land surface and subsurface resistivity modeled from time-domain electromagnetic sounding for sites $\mathrm{SH} 7$ and SH8.

39. Graphs showing relations between $A$, central-loop resistivity, out-of-loop vertical magnetic field, and time elapsed after primary current turnoff; and $B$, depth below land surface and subsurface resistivity modeled from timedomain electromagnetic sounding for sites TDEM8 and TDEM9.

40. Graphs showing relations between $A$, central-loop resistivity, out-of-loop vertical magnetic field, and time elapsed after primary current turnoff; and $B$, depth below land surface and subsurface resistivity modeled from timedomain electromagnetic sounding for sites TDEM11 and TDEM16.

41. Graphs showing relations between $A$, central-loop resistivity, out-of-loop vertical magnetic field, and time elapsed after primary current turnoff; and $B$, depth below land surface and subsurface resistivity modeled from timedomain electromagnetic sounding for sites TDEM20 and TDEM41.

42. Graphs showing relations between $A$, central-loop resistivity, out-of-loop vertical magnetic field, and time elapsed after primary current turnoff; and $B$, depth below land surface and subsurface resistivity modeled from timedomain electromagnetic sounding for sites TDEM42 and TDEM43.

43. Graphs showing relations between $A$, central-loop resistivity, out-of-loop vertical magnetic field, and time elapsed after primary current turnoff; and $B$, depth below land surface and subsurface resistivity modeled from timedomain electromagnetic sounding for sites TDEM44 and TDEM48.

44. Graphs showing relations between $A$, central-loop resistivity, out-of-loop vertical magnetic field, and time elapsed after primary current turnoff; and $B$, depth below land surface and subsurface resistivity modeled from timedomain electromagnetic sounding for sites TDEM49 and TDEM68. 
45. Graphs showing relations between $A$, central-loop resistivity, out-of-loop vertical magnetic field, and time elapsed after primary current turnoff; and $B$, depth below land surface and subsurface resistivity modeled from timedomain electromagnetic sounding for sites TDEM69 and TDEM70.

46. Graphs showing relations between $A$, central-loop resistivity and time elapsed after primary current turnoff; and $B$, depth below land surface and subsurface resistivity modeled from time-domain electromagnetic sounding for sites TDEM71 and TDEM79.

47. Graphs showing relations between $A$, central-loop resistivity, out-of-loop vertical magnetic field, and time elapsed after primary current turnoff; and $B$, depth below land surface and subsurface resistivity modeled from timedomain electromagnetic sounding for sites TDEM84 and TDEM86.

48. Graphs showing relations between $A$, central-loop resistivity, out-of-loop vertical magnetic field, and time elapsed after primary current turnoff; and $B$, depth below land surface and subsurface resistivity modeled from timedomain electromagnetic sounding for sites TDEM89 and TDEM90.

49. Graphs showing relations between $A$, central-loop resistivity, out-of-loop vertical magnetic field, and time elapsed after primary current turnoff; and $B$, depth below land surface and subsurface resistivity modeled from timedomain electromagnetic sounding for sites TDEM91 and TDEM99

50. Graphs showing relations between $A$, central-loop resistivity, out-of-loop vertical magnetic field, and time elapsed after primary current turnoff; and $B$, depth below land surface and subsurface resistivity modeled from timedomain electromagnetic sounding for sites TDEM140 and TDEM156

51. Graphs showing relations between $A$, central-loop resistivity and time elapsed after primary current turnoff; and $B$, depth below land surface and subsurface resistivity modeled from time-domain electromagnetic sounding for sites TDEM158 and TDEM177.

52. Graphs showing relations between $A$, central-loop resistivity, out-of-loop vertical magnetic field, and time elapsed after primary current turnoff; and $B$, depth below land surface and subsurface resistivity modeled from timedomain electromagnetic sounding for site TDEM178

53. Graphs showing relations between $A$, central-loop resistivity and time elapsed after primary current turnoff; and $B$, depth below land surface and subsurface resistivity modeled from time-domain electromagnetic sounding for sites TDEM210 and TDEM211

54. Graphs showing relations between $A$, central-loop resistivity, out-of-loop vertical magnetic field, and time elapsed after primary current turnoff; and $B$, depth below land surface and subsurface resistivity modeled from timedomain electromagnetic sounding for sites TDEM212 and TDEM218

55. Graphs showing relations between $A$, central-loop resistivity and time elapsed after primary current turnoff; and $B$, depth below land surface and subsurface resistivity modeled from time-domain electromagnetic sounding for sites TDEM223 and TDEM224

56. Graphs showing relations between $A$, central-loop resistivity, out-of-loop vertical magnetic field, and time elapsed after primary current turnoff; and $B$, depth below land surface and subsurface resistivity modeled from timedomain electromagnetic sounding for sites TDEM228 and TDEM232. 
57. Graphs showing relations between $A$, central-loop resistivity, out-of-loop vertical magnetic field, and time elapsed after primary current turnoff; and $B$, depth below land surface and subsurface resistivity modeled from timedomain electromagnetic sounding for sites UE1 and UE2.

58. Graphs showing relations between $A$, central-loop resistivity, out-of-loop vertical magnetic field, and time elapsed after primary current turnoff; and $B$, depth below land surface and subsurface resistivity modeled from timedomain electromagnetic sounding for sites UE3 and UE4.

59. Graphs showing relations between $A$, central-loop resistivity, out-of-loop vertical magnetic field, and time elapsed after primary current turnoff; and $B$, depth below land surface and subsurface resistivity modeled from timedomain electromagnetic sounding for sites UE5 and UE6.

60. Graphs showing relations between $A$, central-loop resistivity, out-of-loop vertical magnetic field, and time elapsed after primary current turnoff; and $B$, depth below land surface and subsurface resistivity modeled from timedomain electromagnetic sounding for sites UE7 and UE8.

61. Graphs showing relations between $A$, central-loop resistivity, out-of-loop vertical magnetic field, and time elapsed after primary current turnoff; and $B$, depth below land surface and subsurface resistivity modeled from timedomain electromagnetic sounding for sites UE9 and UE10.

62. Graphs showing relations between $A$, central-loop resistivity, out-of-loop vertical magnetic field, and time elapsed after primary current turnoff; and $B$, depth below land surface and subsurface resistivity modeled from timedomain electromagnetic sounding for sites UL1 and UL2

63. Graphs showing relations between $A$, central-loop resistivity, out-of-loop vertical magnetic field, and time elapsed after primary current turnoff; and $B$, depth below land surface and subsurface resistivity modeled from timedomain electromagnetic sounding for sites UL3 and UL4

64. Graphs showing relations between $A$, central-loop resistivity, out-of-loop vertical magnetic field, and time elapsed after primary current turnoff; and $B$, depth below land surface and subsurface resistivity modeled from timedomain electromagnetic sounding for sites UL5 and UL6

65. Graphs showing relations between $A$, central-loop resistivity, out-of-loop vertical magnetic field, and time elapsed after primary current turnoff; and $B$, depth below land surface and subsurface resistivity modeled from timedomain electromagnetic sounding for sites UL7 and UL8

66. Graphs showing relations between $A$, central-loop resistivity, out-of-loop vertical magnetic field, and time elapsed after primary current turnoff; and $B$, depth below land surface and subsurface resistivity modeled from timedomain electromagnetic sounding for sites UL9 and UL10...

67. Graphs showing relations between $A$, central-loop resistivity, out-of-loop vertical magnetic field, and time elapsed after primary current turnoff; and $B$, depth below land surface and subsurface resistivity modeled from timedomain electromagnetic sounding for sites UL11 and UL12

68. Graphs showing relations between $A$, central-loop resistivity, out-of-loop vertical magnetic field, and time elapsed after primary current turnoff; and $B$, depth below land surface and subsurface resistivity modeled from timedomain electromagnetic sounding for sites UL13 and UL14

69. Graphs showing relations between $A$, central-loop resistivity, out-of-loop vertical magnetic field, and time elapsed after primary current turnoff; and $B$, depth below land surface and subsurface resistivity modeled from timedomain electromagnetic sounding for sites UL15 and UL16 
70. Graphs showing relations between $A$, central-loop resistivity, out-of-loop vertical magnetic field, and time elapsed after primary current turnoff; and $B$, depth below land surface and subsurface resistivity modeled from timedomain electromagnetic sounding for sites UL18 and UL19

71. Graphs showing comparison of results from time-domain electromagnetic minimum-layer model, University of Nebraska-Lincoln Conservation and Survey Division test holes, and Nebraska Oil and Gas Conservation Commission test holes.

72. Map showing five regions within the Elkhorn-Loup Model study area containing Plio-Pleistocene gravel deposits identified by modeled time-domain electromagnetic soundings

\section{Tables}

1. Stratigraphic, lithologic, and hydrostratigraphic column of the High Plains aquifer system and confining units, Elkhorn-Loup Model study area, Nebraska.

2. Field name, site number, legal description, location, and selected drilling data of test holes, Elkhorn-Loup Model study area, 2010..

3. Summary by site of Elkhorn-Loup Model time-domain electromagnetic sounding locations and acquired resistivity data

4. Stratigraphic contacts resulting from minimum-layer time-domain electromagnetic models of sounding sites, Elkhorn-Loup Model study area, 2010

5. Comparison of elevations of selected stratigraphic contacts based on minimum-layer time-domain electromagnetic model results and test-hole stratigraphy at Quality Control sites, Elkhorn-Loup Model study area, Nebraska 


\section{Conversion Factors}

Inch/Pound to SI

\begin{tabular}{|c|c|c|}
\hline Multiply & By & To obtain \\
\hline \multicolumn{3}{|c|}{ Length } \\
\hline inch (in.) & 2.54 & centimeter $(\mathrm{cm})$ \\
\hline inch (in.) & 25.4 & millimeter $(\mathrm{mm})$ \\
\hline foot (ft) & 0.3048 & meter $(\mathrm{m})$ \\
\hline mile (mi) & 1.609 & kilometer $(\mathrm{km})$ \\
\hline \multicolumn{3}{|c|}{ Rate } \\
\hline inches per year (in./yr) & 25.4 & millimeters per year (mm/yr) \\
\hline \multicolumn{3}{|c|}{ Hydraulic gradient } \\
\hline foot per mile (ft/mi) & 0.1894 & meter per kilometer $(\mathrm{m} / \mathrm{km})$ \\
\hline \multicolumn{3}{|c|}{ Area } \\
\hline acre & 4,047 & square meter $\left(\mathrm{m}^{2}\right)$ \\
\hline acre & 0.4047 & hectare (ha) \\
\hline acre & 0.4047 & square hectometer $\left(\mathrm{hm}^{2}\right)$ \\
\hline acre & 0.004047 & square kilometer $\left(\mathrm{km}^{2}\right)$ \\
\hline square foot $\left(\mathrm{ft}^{2}\right)$ & 0.09290 & square meter $\left(\mathrm{m}^{2}\right)$ \\
\hline square mile $\left(\mathrm{mi}^{2}\right)$ & 259 & hectare (ha) \\
\hline square mile $\left(\mathrm{mi}^{2}\right)$ & 2.590 & square kilometer $\left(\mathrm{km}^{2}\right)$ \\
\hline \multicolumn{3}{|c|}{ Flow rate } \\
\hline gallon per minute (gal/min) & 0.06309 & liter per second $(\mathrm{L} / \mathrm{s})$ \\
\hline \multicolumn{3}{|c|}{ Frequency } \\
\hline Cycles per second & 1 & hertz $(\mathrm{Hz})$ \\
\hline \multicolumn{3}{|c|}{ Magnetic moment } \\
\hline Ampere-square foot $\left(\mathrm{A}-\mathrm{ft}^{2}\right)$ & 0.09290 & Ampere-square meters $\left(\mathrm{A}-\mathrm{m}^{2}\right)$ \\
\hline
\end{tabular}

Temperature in degrees Fahrenheit $\left({ }^{\circ} \mathrm{F}\right)$ may be converted to degrees Celsius $\left({ }^{\circ} \mathrm{C}\right)$ as follows: ${ }^{\circ} \mathrm{C}=\left({ }^{\circ} \mathrm{F}-32\right) / 1.8$

Vertical coordinate information is referenced to the National Geodetic Vertical Datum of 1929 (NGVD 29)

Horizontal coordinate information is referenced to the North American Datum of 1983 (NAD 83) 


\title{
Hydrostratigraphic Interpretation of Test-Hole and Surface Geophysical Data, Elkhorn and Loup River Basins, Nebraska, 2008 to 2011
}

\author{
By Christopher M. Hobza, Paul A. Bedrosian, and Benjamin R. Bloss
}

\section{Abstract}

The Elkhorn-Loup Model (ELM) was begun in 2006 to understand the effect of various groundwater-management scenarios on surface-water resources. During phase one of the ELM study, a lack of subsurface geological information was identified as a data gap. Test holes drilled to the base of the aquifer in the ELM study area are spaced as much as 25 miles apart, especially in areas of the western Sand Hills. Given the variable character of the hydrostratigraphic units that compose the High Plains aquifer system, substantial variation in aquifer thickness and characteristics can exist between test holes. To improve the hydrogeologic understanding of the ELM study area, the U.S. Geological Survey, in cooperation with the Nebraska Department of Natural Resources, multiple Natural Resources Districts participating in the ELM study, and the University of Nebraska-Lincoln Conservation and Survey Division, described the subsurface lithology at six test holes drilled in 2010 and concurrently collected borehole geophysical data to identify the base of the High Plains aquifer system. A total of 124 time-domain electromagnetic (TDEM) soundings of resistivity were collected at and between selected testhole locations during 2008-11 as a quick, non-invasive means of identifying the base of the High Plains aquifer system.

Test-hole drilling and geophysical logging indicated the base-of-aquifer elevation was less variable in the central ELM area than in previously reported results from the western part of the ELM study area, where deeper paleochannels were eroded into the Brule Formation. In total, more than 435 test holes were examined and compared with the modeled-TDEM soundings. Even where present, individual stratigraphic units could not always be identified in modeled-TDEM sounding results if sufficient resistivity contrast was not evident; however, in general, the base of aquifer [top of the aquifer confining unit (ACU)] is one of the best-resolved results from the TDEM-based models, and estimates of the base-of-aquifer elevation are in good accordance with those from existing test-hole data. Differences between ACU elevations based on modeled-TDEM and test-hole data ranged from 2 to 113 feet ( 0.6 to 34 meters). The modeled resistivity results reflect the eastward thinning of Miocene-age and older stratigraphic units, and generally allowed confident identification of the accompanying change in the stratigraphic unit forming the ACU. The differences in elevation of the top of the Ogallala, estimated on the basis of the modeled-TDEM resistivity, and the test-hole data ranged from 11 to 251 feet (3.4 to 77 meters), with two-thirds of model results being within 60 feet of the test-hole contact elevation. The modeled-TDEM soundings also provided information regarding the distribution of Plio-Pleistocene gravel deposits, which had an average thickness of 100 feet (30 meters) in the study area; however, in many cases the contact between the Plio-Pleistocene deposits and the overlying Quaternary deposits cannot be reliably distinguished using TDEM soundings alone because of insufficient thickness or resistivity contrast.

\section{Introduction}

Newly adopted legislation in Nebraska requires a sustainable balance between long-term water supplies and uses of surface water and groundwater (Ostdiek, 2009), and requires Natural Resources Districts (NRDs) to include the effect of groundwater use on surface-water systems as part of their groundwater-management plan. Recent drought (2000-2006) has increased concerns about the long-term sustainability of surface-water and groundwater resources, and the effect of groundwater irrigation on streamflow in the State of Nebraska (Peterson and others, 2008). The Elkhorn-Loup Model (ELM) was begun in 2006 (Peterson and others, 2008; Stanton and others, 2010) to understand the effect of various groundwatermanagement scenarios on surface-water resources. The ELM study area covers about 30,800 square miles $\left(\mathrm{mi}^{2}\right)$ and includes the entire drainage area of the Loup River and its tributaries and the upper part of the Elkhorn River drainage area (fig. 1). Upper parts of both stream systems provide substantial amounts of water as base flow to more intensely irrigated areas downstream. Streamflow within the ELM area can be sensitive to consumptive groundwater use because of interaction between groundwater and surface water. The complexity of 


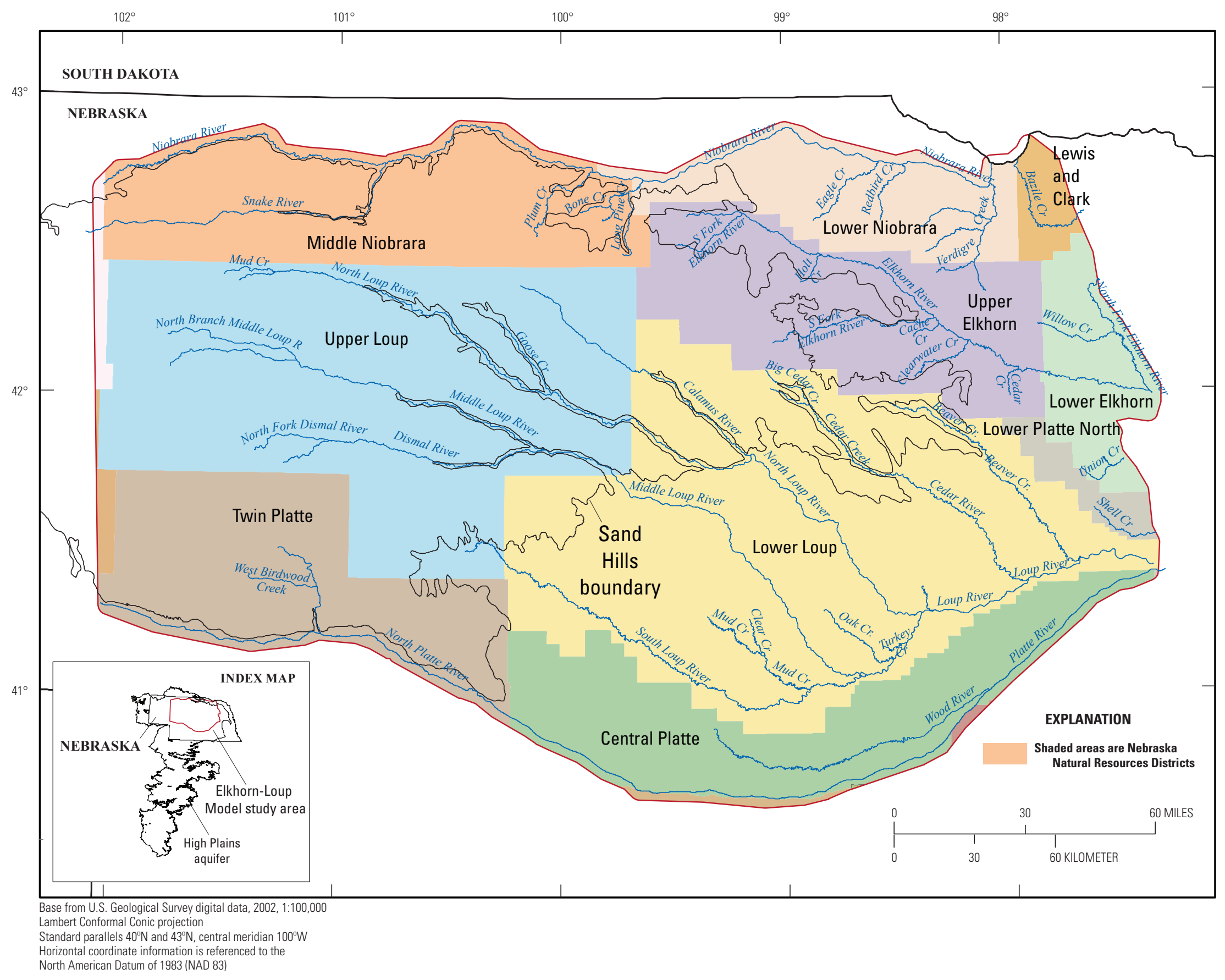

Figure 1. Location of the Elkhorn-Loup Model study area and Natural Resources Districts, Nebraska. 
this hydrologic system and the interaction between the available surface-water and groundwater resources are not fully understood at present.

The ELM study is a coordinated effort involving the Upper Elkhorn, Lower Elkhorn, Upper Loup, Lower Loup, Middle Niobrara, Lower Niobrara, Lewis and Clark, and Lower Platte North NRDs (collectively referred to hereinafter as the ELM NRDs), the Nebraska Department of Natural Resources, the University of Nebraska-Lincoln, Conservation and Survey Division (CSD), and the U.S. Geological Survey (USGS). The ELM study approach comprises three separate phases. Phase one included the initial model construction and calibration of simulated groundwater flow (Peterson and others, 2008). Phase two included updates to the groundwaterflow simulation using newly collected data and supporting analyses completed in 2007 and 2008, improved simulation calibration methods, and additional approaches for analyzing the effects of agricultural irrigation (Stanton and others, 2010). The newly collected data include revisions to the base-of-aquifer map (McGuire and Peterson, 2008) using test-hole drilling and borehole geophysics. Phase three will incorporate additional geologic and geophysical data collected in the Upper Loup NRD (Hobza and others, 2011), including the datasets reported herein.

During phase one of the ELM study, a lack of subsurface geological information was identified as a data gap. Test holes drilled to the base of aquifer in the ELM study area are spaced up to 25 miles (mi) apart, especially in areas of the western Sand Hills, which requires interpolation of subsurface data over long distances. Given the variable character of the hydrostratigraphic units that compose the High Plains aquifer system, substantial variation in aquifer thickness and characteristics can exist between test holes. To improve the hydrogeologic understanding of the ELM study area, the USGS, in cooperation with the Nebraska Department of Natural Resources, the ELM NRDs, and the University of NebraskaLincoln Conservation and Survey Division, described the lithology of drill cuttings collected from six test holes, and concurrently collected borehole geophysical data to identify selected hydrostratigraphic contacts at these locations. Surface geophysical data also were collected from 2008 to 2011 at 124 locations using time-domain electromagnetic (TDEM) methods at and between selected test-hole locations across the ELM study area as a quick, non-invasive means of identifying the base of the High Plains aquifer system. The data collected for this study allow improved knowledge of the aquifer thickness and the topography of the base-of-aquifer surface, which are important for assessing water supply and understanding groundwater flow.

\section{Purpose and Scope}

The purpose of this report is to provide a hydrostratigraphic interpretation of test-hole and surface geophysical data collected from 2008 to 2011 in the ELM study area. This report documents the methods of data collection and analysis, presents test-hole and surface geophysical survey results and interpretations, and examines the utility of these techniques for improved understanding of the hydrostratigraphic framework. Included in this report are the generalized lithologic and borehole geophysical logs from all six test holes and additional TDEM surface geophysical data that were collected. The geologic and geophysical data collected from additional test holes and surface geophysical soundings across the ELM study area are intended to refine interpretations of the base-of-aquifer surface being used for phase three of the ELM study.

A previous, related report was aimed at improving understanding of the hydrostratigraphic framework of the Upper Loup NRD (fig. 1) using surface geophysical and test-hole drilling information (Hobza and others, 2011). This report expands the previous study area to encompass the entire ELM study area and includes refinements to the initial interpretations provided by Hobza and others (2011).

\section{Study Area Description}

The ELM study area extends from the Niobrara River on the northern boundary to the Platte River on the southern boundary (fig. 1). The western boundary coincides roughly with the western boundary of the Upper Loup and Middle Niobrara NRDs, and the eastern boundary coincides roughly with the approximate location of the westernmost extent of glacial till in eastern Nebraska (Peterson and others, 2008). The ELM study area covers approximately 60 percent of the Sand Hills and overlies the nationally important High Plains aquifer system (fig. 1). The Sand Hills region of Nebraska is characterized as the largest dune field in the Western Hemisphere and currently is stabilized by vegetation (Bleed, 1989).

Land use varies across the study area. Most of the Sand Hills, such as in the headwaters of the Loup and Elkhorn Rivers, primarily is undeveloped rangeland. Areas to the east are dominated by row-crop agriculture, with corn and soybeans being the principal crop types (Strauch and Linard, 2009).

The climate in the ELM study area is characterized by cold winters and warm summers typical of continental midlatitude locations. Strauch and Linard (2009) examined records from precipitation gages in and around the study area from October 1939 to September 2005 and reported that mean annual precipitation increases from west to east from 17 to 27 inches (in.), with the highest precipitation occurring during the summer months. Potential evaporation, similar to precipitation, is greatest during the crop-growing season of April through September, peaks in July, and often exceeds precipitation (Chen and others, 2003). Mean annual evapotranspiration (ET) in the study area ranges from 19 inches per year (in/yr) in the east to $16 \mathrm{in} / \mathrm{yr}$ in the west (Dugan and Zelt, 2000).

More than one-half of the surface of the ELM study area is covered by the Sand Hills, where Quaternary eolian dunes and alluvial deposits in modern stream valleys cover the land surface (Swinehart and Diffendal, 1989). Unique physical 
characteristics of the Sand Hills have allowed a net gain to the groundwater system from recharge of meteoric water with time and resulted in a substantial amount of water being stored. Runoff-induced high-flow events are rare within the Sand Hills because of the ability of permeable soils to infiltrate even heavy precipitation. Strauch and Linard (2009) reported the simulated maximum deep percolation rate in the Sand Hills can exceed $12 \mathrm{in} / \mathrm{yr}$. This results in streamflow that is dominated by groundwater discharge (base flow). Bentall (1989) estimated that the Middle Loup and Dismal Rivers (fig. 1) above Dunning, Nebr. (Dunning not shown in fig. 1; located near the confluence of the Middle Loup and Dismal Rivers), have base flows exceeding 95 percent of total streamflow; therefore, streamflow in the Middle Loup and Dismal Rivers remains steady even during periods of drought and responds more slowly to changes in climatic conditions compared to streams in the eastern Sand Hills where base-flow contribution to total streamflow is less (Chen and others, 2003).

\section{Geologic Setting}

The ELM study area overlies the High Plains aquifer system, where saturated thicknesses can exceed 1,000 feet (ft) [305 meters (m)] (McGuire and Fischer, 1999). The High Plains aquifer system is considered to be inclusive of all hydrologically connected Tertiary and Quaternary units. According to Gutentag and others (1984), these units include the fractured part of the Tertiary rocks, the Oligocene Brule Formation of the White River Group (herein referred to as the Brule), the Miocene Arikaree Group (herein referred to as the Arikaree), the Miocene Ogallala Formation (herein referred to as the Ogallala), and Quaternary-age alluvial and eolian deposits. The unfractured Brule or, where the Brule is not present, the Cretaceous Pierre Shale generally form the base of aquifer. The base of aquifer surface generally dips 8 feet per mile ( $\mathrm{ft} / \mathrm{mi}$ ) east and contains paleovalleys that also drain eastward (Peterson and others, 2008). All previously mentioned units are shown in the hydrostratigraphic column presented in table 1 .

The geologic history relevant to this study begins roughly 70 million years ago with the deposition of Cretaceous-age sediments. During the Cretaceous period, much of the study area was covered by a shallow inland sea, where marine sediments were deposited to form the Dakota Sandstone, Carlile Shale of the Colorado Group (herein referred to as the Carlile Shale), Niobrara Formation of the Colorado Group (herein referred to as the Niobrara), and Pierre Shale. Following regression of the Cretaceous sea, uplift resulted in formation of the Chadron and Cambridge arches trending from northwest to southeast across the ELM area (Swinehart and others, 1985). Subsequent fluvial erosion removed up to $1,800 \mathrm{ft}$ $(550 \mathrm{~m})$ of the Cretaceous section and created a structural low over the previously uplifted region.

In the western part of the study area, the Brule and Chadron Formation of the White River Group (herein referred to as the Chadron) unconformably overlie the Pierre Shale (table 1). The Chadron consists of tuffaceous claystone, siltstone, and mudstone (Swinehart and others, 1985). Condon (2005) and Swinehart and others (1985) indicated that the Chadron underlies the extreme western part of the study area and isolated remnants underlie the eastern part (Diffendal and others, 2008). The unfractured Brule forms the base of aquifer in much of the western part of the ELM area. The Brule is a massive siltstone composed of primarily eolian silt but also may contain embedded fluvial units. Deposits of volcaniclastic sediments and some ash derived from volcanic complexes from the western United States make up most of its volume (Souders, 2000). When unfractured, the Brule is impermeable relative to the overlying units.

Overlying the Brule is the Arikaree, which is largely limited to the western part of the study area but may exist in paleovalleys to the east (Swinehart and Diffendal, 1989). The Arikaree is a massive, very fine to fine-grained sandstone with localized beds of volcanic ash, silty sand, and sandy clay (Darton, 1903; Condra and Reed, 1943). The Arikaree is considered part of the High Plains aquifer system; however, it does not yield large quantities of water to wells (Gutentag and others, 1984). Within the ELM area, the Arikaree typically is not used as a water source.

The Ogallala is the principal geologic unit in the High Plains aquifer system and reaches a thickness of $800 \mathrm{ft}$ $(240 \mathrm{~m})$ beneath the western ELM area (Diffendal, 1991). The Ogallala is composed of a poorly sorted mixture of sand, silt, clay, and gravel (Condra and Reed, 1943). The Ogallala is generally unconsolidated or weakly consolidated but can contain layers of sandstone cemented by calcium carbonate or limestone. When covered by younger deposits, the Ogallala has not been subdivided into stratigraphic units recognized in other areas because of the difficulty correlating these units in the subsurface. The Ogallala was deposited by aggrading streams that filled paleovalleys that were eroded into preOgallala rocks (Swinehart and others, 1985). The base of the Ogallala is a complex surface formed from multiple episodes of erosion. The location of some Ogallala paleovalleys has been proposed by previous researchers (Swinehart and Diffendal, 1989; Swinehart and others, 1985), but these may represent only a fraction of the drainage network that existed during Miocene time. Much of the deposition was restricted to valleys along drainage systems originating from mountains in Wyoming and Colorado (Swinehart and others, 1985), but deposition may have occurred on broad low-relief plains as well (Swinehart and Diffendal, 1989).

An unconformity of at least 1.5 million years separates the Ogallala from the Pliocene Broadwater Formation and the Pleistocene Long Pine Formations (Swinehart and Diffendal, 1989). The Pleistocene Long Pine Formation is used by the CSD and is not formally recognized by the USGS. These sediments, eroded from central Wyoming and northern Colorado (Stanley and Wayne, 1972), are unevenly deposited and preserved, contain coarse sand and gravel separated by finer-grained deposits, and cover the Ogallala through much of the study area. In the ELM area, Pliocene and Pleistocene 
Table 1. Stratigraphic, lithologic, and hydrostratigraphic column of the High Plains aquifer system and confining units, Elkhorn-Loup Model study area, Nebraska.

\begin{tabular}{|c|c|c|c|c|c|c|}
\hline Period & Epoch & \multicolumn{3}{|c|}{ Stratigraphy } & Lithology & Hydrostratigraphy \\
\hline \multirow[b]{2}{*}{ Quaternary } & Holocene & \multicolumn{3}{|c|}{$\begin{array}{l}\text { Alluvium and eolian } \\
\text { deposits }\end{array}$} & \multirow[b]{2}{*}{$\begin{array}{l}\text { Gravel, sand, silt, } \\
\text { and clay }\end{array}$} & \multirow{5}{*}{$\begin{array}{c}\text { High Plains aquifer } \\
\text { system }\end{array}$} \\
\hline & Pleistocene & \multicolumn{3}{|c|}{$\begin{array}{l}\text { Long Pine Formation } \\
\text { and undifferentiated } \\
\text { alluvial and eolian } \\
\text { deposits }\end{array}$} & & \\
\hline \multirow{6}{*}{ Tertiary } & Pliocene & \multicolumn{3}{|c|}{ Broadwater Formation } & Gravel and sand & \\
\hline & \multirow{2}{*}{ Miocene } & \multicolumn{3}{|c|}{ Ogallala Group } & $\begin{array}{l}\text { Gravel, sand, silt, } \\
\text { and clay }\end{array}$ & \\
\hline & & \multicolumn{3}{|c|}{ Arikaree Group } & $\begin{array}{l}\text { Very fine to fine- } \\
\text { grained sandstone }\end{array}$ & \\
\hline & \multirow{2}{*}{ Oligocene } & \multirow{3}{*}{ 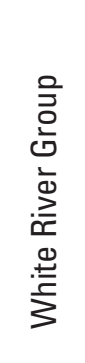 } & \multirow{2}{*}{$\frac{0}{\bar{D}}$} & Upper & $\begin{array}{l}\text { Siltstone and } \\
\text { sandstone }\end{array}$ & \multirow{6}{*}{$\begin{array}{l}\text { Great Plains } \\
\text { confining system }\end{array}$} \\
\hline & & & & Lower & $\begin{array}{l}\text { Siltstone and } \\
\text { claystone }\end{array}$ & \\
\hline & Eocene & & \multicolumn{2}{|c|}{ Chadron Formation } & $\begin{array}{l}\text { Siltstone and } \\
\text { claystone }\end{array}$ & \\
\hline \multirow{4}{*}{ Cretaceous } & \multirow{3}{*}{ Upper } & \multicolumn{3}{|c|}{ Pierre Shale } & Shale & \\
\hline & & \multirow{2}{*}{$\begin{array}{l}\text { 응 음 } \\
\text { 흥 은 }\end{array}$} & \multicolumn{2}{|c|}{ Niobrara Formation } & $\begin{array}{c}\text { Chalk, calcareous } \\
\text { shale }\end{array}$ & \\
\hline & & & \multicolumn{2}{|c|}{ Carlile Shale } & $\begin{array}{l}\text { Shale, limestone, } \\
\text { and sandstone }\end{array}$ & \\
\hline & Lower & \multicolumn{3}{|c|}{ Dakota Sandstone } & $\begin{array}{l}\text { Sandstone and } \\
\text { shale }\end{array}$ & $\begin{array}{c}\text { Great Plains aquifer } \\
\text { system }\end{array}$ \\
\hline
\end{tabular}

Modified from Souders, 2000; Swinehart and Diffendal, 1989; Burchett and others, 1975; Gutentag and others, 1984; and Helgesen and others, 1993.

fluvial deposits average $50 \mathrm{ft}(15 \mathrm{~m})$ in thickness but can be as thick as $300 \mathrm{ft}(91 \mathrm{~m})$ (Swinehart and Diffendal, 1989) and are hydrologically connected with the underlying Ogallala. The Broadwater and Long Pine Formations, as parts of the High Plains aquifer system, are used as a water source where sufficient saturated thicknesses are present. Distinguishing the age of some of these deposits is difficult, if not impossible (Condon, 2005); as such, these deposits are referred to as PlioPleistocene in age.

Quaternary deposits, which consist of wind-deposited silt, clay, and fine-grained sand (together called loess), and alluvial deposits of sand and gravel cover much of the ELM area. Eolian sand and loess deposits typically are not used as a water source because they are mostly above the water table. Quaternary-age alluvial sand and gravel are present in modern stream valleys and are often used as a water source. Where sufficient thicknesses are present, these coarse deposits can sustain well withdrawals of more than 1,000 gallons per minute (63 liters per second) (Peterson and others, 2008). Quaternary deposits can be as thick as $700 \mathrm{ft}(210 \mathrm{~m})$ but typically are 150 to 300 feet (46 to $91 \mathrm{~m}$ ) thick and are absent from uplands near the Niobrara River (University of NebraskaLincoln Conservation and Survey Division, 2011).

\section{Methods}

\section{Site and Method Selection}

This section of the report details the rationale for the selection of test-hole and geophysical data-collection locations. Site selection for test-hole drilling and surface geophysical data collection was guided by several factors, but primarily was intended to fill existing gaps in the test-hole database 
(University of Nebraska-Lincoln Conservation and Survey Division, 2011). A subset of surface geophysical sounding sites was located near previously drilled or planned test-hole locations for ground-truth purposes. Test-hole drilling and geophysical data-collection locations also depended on site accessibility and landowner permission.

Geophysical methods were selected on the basis of physical characteristics of the hydrostratigraphic units of the ELM area and the anticipated depth to the base of aquifer. Examination of previously collected CSD borehole geophysical logs indicated a sharp contrast in electrical resistivity between the Brule or Pierre Shale and the overlying Tertiary units of the High Plains aquifer system. After considering the anticipated depth to the base of aquifer (top of the Brule or Pierre Shale), the TDEM method was chosen. This surface geophysical method detects variations in the electrical properties of earth materials - in particular, electrical resistivity in units of ohmmeters (ohm-m), or its reciprocal, electrical conductivity in units of siemens/meter $(\mathrm{S} / \mathrm{m})$. Electrical resistivity measurements are sensitive to water content and quality, and changes in lithology. In the absence of clay or other conductive material (such as dissolved solids in pore water), lower electrical resistivity corresponds to higher porosity, smaller grain size, or both because of the greater surface area associated with fine particles that promotes the transmission of electrical current (Biella and others, 1983; Kwader, 1985); higher resistivity is associated with coarse-grained deposits, such as alluvial sand and gravel or sandstone. As such, electrical resistivity can be correlated with geologic units on the surface and at depth using lithologic logs to provide a picture of subsurface geology. The principles of operation and field application of each technique are explained in detail in the "Surface Geophysical Data Collection and Analysis" section of this report. More information regarding the electrical properties of differing types of rocks can be found in Keller (1987, 1989), Palacky (1987), Hearst and Nelson (1985), Hallenburg (1998), and Hearst and others (2000).

\section{Test-Hole Drilling and Borehole Geophysics}

The generalized lithologic descriptions and borehole geophysical logs for six test holes drilled to the base of the High Plains aquifer (top of the silt and siltstone of Brule or Pierre Shale) are presented in the "Test-Hole Lithologic and Borehole Geophysical Logs" section and "Supplemental Data" section of this report. A map of all test holes is shown in figure 2, with location coordinates and other information presented in table 2. Original copies of the lithologic logs of each test hole are kept on file at the USGS Nebraska Water Science Center in Lincoln, Nebr. All borehole geophysical logs are archived in accordance with USGS protocol (U.S. Geological Survey, written commun., 2009). At the time of this report (2012), final stratigraphic interpretations of the test-hole data have not been completed. Consequently, the stratigraphic units composing the High Plains aquifer system are undifferentiated, and only the base of aquifer at each test hole has been interpreted.

\section{Test-Hole Drilling Methods}

Test-hole drilling with mud rotary drilling equipment has been an integral part of groundwater and geologic studies in Nebraska for many years (Goeke, 2000). Mud rotary drilling and sampling requires the use of mud suitable for geologic conditions encountered during drilling. As the drill stem was advanced, the time required to advance each increment was recorded as well as the drilling action. Drill cuttings were circulated to the surface, collected, examined immediately, and lithologically described. Described samples were bagged, labeled, and provided to the CSD for further examination under a petrographic microscope before the final assignment of stratigraphic intervals and publication in the CSD test-hole database.

Table 2. Field name, site number, legal description, location, and selected drilling data of test holes, Elkhorn-Loup Model study area, 2010.

[Site number, site identification number assigned by U.S. Geological Survey; legal descriptions, T., township; N, north; R., range; W, west; S., section; ABCD, codes for the quarter section, quarter-quarter section, quarter-quarter-quarter section, and quarter-quarter-quarter-quarter sections $\mathrm{A}, \mathrm{B}, \mathrm{C}$, and $\mathrm{D}$, respectively, where A is northeast, B is northwest, C is southwest, and D is southeast quarter of the next larger unit; northing and easting in Nebraska State Plane feet; landsurface elevation in feet above National Geodetic Vertical Datum of 1929 (NGVD 29), elevations to the nearest foot; estimated minus drilled, indicates the estimated base-of-aquifer elevation, from McGuire and Peterson (2008), minus the drilled base-of-aquifer elevation at test hole, in feet]

\begin{tabular}{|c|c|c|c|c|c|c|c|c|}
\hline $\begin{array}{l}\text { Field } \\
\text { name }\end{array}$ & Site number & $\begin{array}{c}\text { Legal } \\
\text { description }\end{array}$ & $\begin{array}{c}\text { Northing, } \\
\text { in feet }\end{array}$ & $\begin{array}{l}\text { Easting, } \\
\text { in feet }\end{array}$ & $\begin{array}{l}\text { Land-surface } \\
\text { elevation, } \\
\text { in feet }\end{array}$ & $\begin{array}{l}\text { Date } \\
\text { drilled }\end{array}$ & $\begin{array}{c}\text { Drilled depth } \\
\text { to base of } \\
\text { aquifer, } \\
\text { in feet }\end{array}$ & $\begin{array}{c}\text { Estimated } \\
\text { minus } \\
\text { drilled, } \\
\text { in feet }\end{array}$ \\
\hline 2-LL-10 & 413433099281101 & T.19N R.19W S.35 ACDC & 635,160 & $1,785,459$ & 2,563 & $8 / 11 / 2010$ & 805 & -8 \\
\hline 3-LL-10 & 412407099265301 & T.17N R.19W S.36 DABB & 571,818 & $1,791,775$ & 2,461 & $8 / 12 / 2010$ & 695 & 34 \\
\hline 6-LL-10 & 411613099425101 & T.15N R.21W S.15 CABB & 523,546 & $1,718,974$ & 2,539 & $8 / 19 / 2010$ & 645 & -44 \\
\hline 7-LL-10 & 411308099261401 & T.14N R.19W S.1 AABB & 505,171 & $1,795,195$ & 2,463 & $8 / 24 / 2010$ & 565 & -48 \\
\hline
\end{tabular}




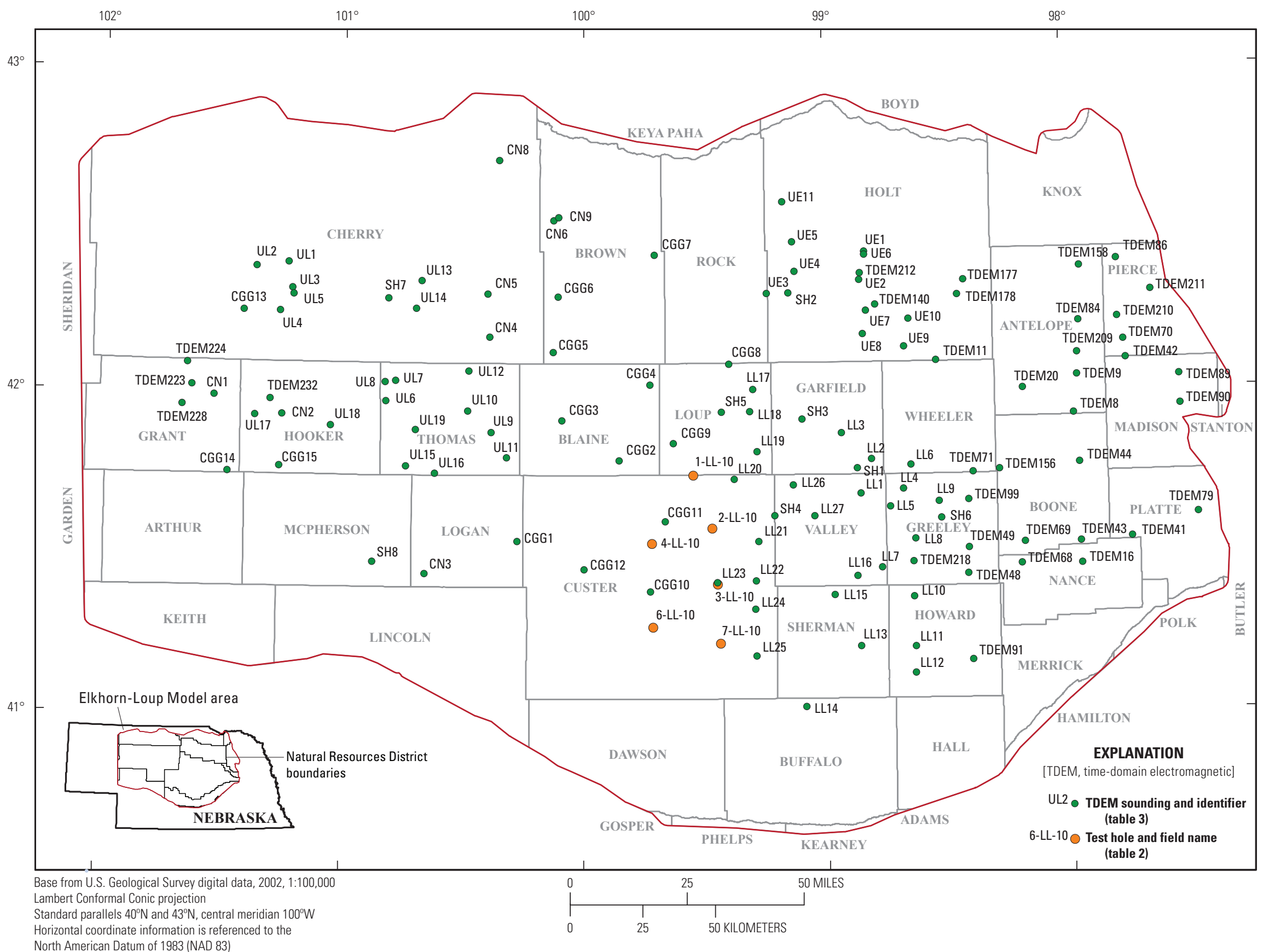

Figure 2. Location of test holes and time-domain electromagnetic (TDEM) soundings, Elkhorn-Loup Model study area, 2008-2011. 
For this report, even though precise contacts of certain hydrostratigraphic units have not been determined, lithologic characteristics were noted that can provide information on the hydrostratigraphic units sampled. The top of the Ogallala was determined by the presence of siliceous plant roots (rootlets) that are easily recognized in drill cuttings. This approach has been used by other investigators (Cast, 2000; Goeke, 2000; Wigley, 2000; University of NebraskaLincoln Conservation and Survey, 2011). Furthermore, Condra and Reed (1943) stated that in most areas of western and north-central Nebraska, rocks of late Tertiary age contain numerous fossil seeds of grasses and forage herbs that provide the best means to identify Tertiary units from the upper part of the Arikaree to the top of the Ogallala (Condra and Reed, 1943).

\section{Borehole Geophysical Data Collection}

Borehole geophysical data were collected at each testhole location using a Century 8144 Multi-Parameter E-Log tool (Century Geophysical Corp., 2012). The Century 8144 tool measures long-normal [64 in. $(1.6 \mathrm{~m})$ tool electrode spacing] and short-normal [16 in. $(0.41 \mathrm{~m})$ tool electrode spacing] resistivity, natural gamma, spontaneous potential, temperature, and fluid resistivity. The types of geophysical logs collected are described briefly in the following paragraphs. Further information regarding borehole geophysics can be found in reports such as Keys (1990).

Normal-resistivity logs measure the electrical resistivity of rocks and water surrounding the borehole. Electrical resistivity measurements consisted of short-normal [16 in. $(0.41 \mathrm{~m})$ ], and long-normal [64 in. $(1.6 \mathrm{~m})$ ], each having different volumes of investigation. Short-normal logs have a smaller volume of investigation and, therefore, are more affected by the resistivity of the drilling fluid and mud cake that develops on the borehole wall. Correspondingly, longnormal logs have a larger volume of investigation and are less affected by drilling fluid. Intervals where these two logs diverge indicate areas of permeability where drilling fluid has invaded the formation (Anderson and others, 2009).

A natural gamma log measures natural gamma radiation being emitted by the formation surrounding the borehole (Keys, 1990). Clays tend to accumulate radioisotopes through adsorption and ion-exchange processes. Most clays, particularly illites, have high gamma emissions because of the presence of potassium in their crystal structure. Zones of high gamma activity are typically interpreted as being clayrich. Volcanic ash, organic shales, and feldspathic or arkosic sandstones also can give higher gamma responses (Anderson and others, 2009).

Spontaneous-potential logs (often referred to as selfpotential, or SP) measure differences in the electrical potentials that develop in a borehole at lithologic or water-quality interfaces (Anderson and others, 2009). Differences in electrical potential often are caused by differences in salinity between the borehole fluid and the formation fluid (Keys,
1990). When the borehole fluid is fresher (less saline) than the formation fluid, electric current flow is such that SP will deflect in a negative direction; conversely, when the formation fluid is fresher (less saline) than the borehole fluid, then electric current flow is such that SP will deflect in a positive direction (Stanton and others, 2007).

Test holes were logged to a depth below the base of the High Plains aquifer, with the exception of test holes 3-LL-10 and 7-LL-10. These two test holes were drilled through the geologic units composing the High Plains aquifer system and into the Pierre Shale. When the drill stem was removed before logging these test holes, drill cuttings from the Pierre Shale stuck on the bit, and the drill stem fell down hole and bridged. This prevented the multi-parameter E-log tool from being lowered down to the bottom of the test holes, resulting in incomplete borehole geophysical logs for both test holes. As a result, the base of the High Plains aquifer system at these locations was interpreted solely on the basis of lithologic description of recovered drill cuttings.

One test-hole drilling location, site 5-LL-10 (not shown on map), was abandoned after several attempts of drilling because of drilling-fluid loss. Drilling-fluid loss occurred several times before the water table was reached, which likely was caused by cracks and voids in the thick loess deposits above the water table in the area. This test-hole location subsequently was moved to site 7-LL-10.

\section{Surface Geophysical Data Collection and Analysis}

\section{Time-Domain Electromagnetic (TDEM) Sounding Method}

TDEM is an inductive electromagnetic technique that provides a measure of near-surface resistivity by passing a current through a wire loop which, as explained by Ampere's law, generates a primary magnetic field. The primary current is rapidly turned off, thereby causing a time-varying change in magnetic flux, which induces voltages, and hence eddy currents, in conductive bodies, according to Faraday's law of induction. In applying the TDEM method, secondary magnetic fields are produced by the decay of these subsurface eddy currents, and typically are measured with one or more receiver wire loops at land surface. An apparent resistivity is calculated from the measured voltage at the receiver coil and the time elapsed after primary current turnoff.

The apparent resistivity is solely a mathematical transform; however, it serves two important purposes. First, subtle differences in the receiver-measured voltage, caused by changes in subsurface resistivity, are accentuated by the power-law dependence of apparent resistivity on elapsed time and voltage. Second, the TDEM response of a homogenous, isotropic earth is such that the apparent resistivity is time dependent, but asymptotic to the true resistivity at late times after turnoff. For more complicated, heterogeneous earth 
structures, the variation of apparent resistivity with time can be viewed as a proxy for the variation of true-earth resistivity with depth. The actual electrical resistivity distribution in the earth is computed from measured apparent resistivity data through the process of inversion. Additional details on the TDEM sounding method can be found in Christiansen and others (2011), Fitterman and Labson (2005), Danielsen and others (2003), and Nabighian and Macnae (1991).

\section{TDEM Data Collection}

A total of 124 TDEM soundings were collected within the ELM study area between 2008 and 2011 (fig. 2; table 3). In 2008, eight soundings were acquired in close proximity to previously drilled CSD test holes. An additional eight soundings were collected in 2009, three of which were followed up by new test holes. The 2010 data collection expanded to 57 soundings, and in 2011 an additional 51 soundings were collected; in both years, locations with sparse test-hole coverage were specifically targeted. A subset of the TDEM soundings within the Upper Loup Natural Resources District was described previously in Hobza and others (2011), but for completeness is repeated in this report.

TDEM data were collected using two systems: a Zonge NanoTEM/ZeroTEM system (Zonge International, Tuscon Ariz., http://www.zonge.com/Zonge.html) was used in 2008, and a Geonics ProTEM system (Geonics Limited, Mississauga, Ontario, http://www.geonics.com/) was used during 2009 through 2011. All data were collected using a 328- by 328 -ft (100- by $100-\mathrm{m})$ square transmitter loop. The depth of investigation (DOI) scales with the transmitter moment (number of wire turns times transmitter current times transmitter loop area), with a rule of thumb placing the DOI at 2 to 3 times the length of a side of the square transmitter loop. At all locations, data were collected in a central-loop configuration, where the receiver loop was placed at the center of the transmitter loop. From 2009 onward, additional data were collected outside of the transmitter loop at a distance of $328 \mathrm{ft}(100 \mathrm{~m})$ from the central receiver location. Out-of-loop data were used as a qualitative check on the assumption of one-dimensionality (layer-cake earth structure) required for subsequent modeling and inversion. Out-of-loop data are recorded as the time derivative of the secondary magnetic field or $d B / d t$, where $B$ is the magnetic induction and $t$ is time. The out-of-loop data also were modeled and inverted together with the central-loop data to better constrain the final resistivity models; however, at many sites the early time out-of-loop data were inconsistent with the early time central-loop data. This inconsistency can indicate lateral variability in near-surface resistivity; however, early time data also are extremely sensitive to the exact positioning of the out-of-loop receiver, and as such, the inconsistency may reflect inaccuracy in the receiver position. Only the in-loop data were modeled at sites that demonstrated this inconsistency.
Calibration of a TDEM system is essential to an accurate recovery of near-surface resistivity structure (Christiansen and others, 2011). Calibration, in this context, refers to a particular combination of data logger, transmitter, and receiver, and involves the characterization of system filters, the knowledge of system geometry, measurement of the transmitted waveform, an assessment of system bias, and correction for timing and normalization errors. The ProTEM and Zonge systems used in this study were calibrated in 2009 at an established test site at Lyngby, Denmark (Geological Institute, 2002a and $2002 b$ ). The ProTEM system was re-calibrated in 2011 following system repairs.

During 2009 through 2011, data were collected at a range of base frequencies [285, 75, 30, 7.5, and 3 hertz $(\mathrm{Hz})]$ using a combination of high- and low-frequency receivers together with low- and high-current transmitters. Average current was 2.0 amperes (A) for the low-current transmitter and 10.0 A for the high-current transmitter; however, when signal levels were low (for example, at the $3-\mathrm{Hz}$ base frequency) the current was raised to $20 \mathrm{~A}$. Average transmitter moments of 215,280 ampere-square feet (A-ft') $\left(20,000 \mathrm{~A}-\mathrm{m}^{2}\right)$; $1,076,390 \mathrm{~A}-\mathrm{ft}^{2}\left(100,000 \mathrm{~A}-\mathrm{m}^{2}\right)$; and 2,152,780 A-ft ${ }^{2}$ $\left(200,000 \mathrm{~A}-\mathrm{m}^{2}\right)$ were produced at 2-A, 10-A, and 20-A currents, respectively.

Data acquired with the Zonge system utilized low- and high-power transmitters, coupled with two receivers, a single-turn 16.4- by 16.4-ft (5- by 5-m) loop receiver and a TEM/3 induction coil receiver, respectively. Data were recorded at base frequencies of 32 and $2 \mathrm{~Hz}$, with average currents of 7 and $26 \mathrm{~A}$, respectively, giving rise to transmitter moments ranging from $753,470 \mathrm{~A}-\mathrm{ft}^{2}\left(70,000 \mathrm{~A}-\mathrm{m}^{2}\right)$ to $2,798,620 \mathrm{~A}-\mathrm{ft}^{2}\left(260,000 \mathrm{~A}-\mathrm{m}^{2}\right)$. At each base frequency, as many as 1,024 transients (data curves) were averaged to form a single, stored data record. A minimum of 20 data records were collected to permit robust error calculation. Background noise measurements also were made with each receiver at each station by acquiring data with the transmitters turned off. Such noise measurements are used during processing to determine the time beyond which measured data are contaminated by background noise. As a general rule, late-time data were culled when signal-to-noise ratios fell below 10 .

All data collected with the ProTEM system used air coil receivers with moments of $338 \mathrm{~A}-\mathrm{ft}^{2}\left(31.4 \mathrm{~A}-\mathrm{m}^{2}\right)$ and $2,150 \mathrm{~A}-\mathrm{ft}^{2}\left(200 \mathrm{~A}-\mathrm{m}^{2}\right)$ for high- and low-frequency coils, respectively. At each base frequency, transients were averaged for elapsed time between 4 and 15 seconds to form a single, stored data record. A minimum of 20 such records were collected to permit robust error calculation. Background noise measurements also were made with each receiver at each station by acquiring data with the transmitter turned off. In general, late-time data were culled when signal-to-noise ratios fell below 10 . 
Table 3. Summary by site of Elkhorn-Loup Model time-domain electromagnetic sounding locations and acquired resistivity data.

[Northing and easting in Nebraska State Plane coordinates; land-surface elevation in feet above National Geodetic Vertical Datum of 1929 (NGVD 29); DOI, estimated depth of investigation; MLM r.m.s., minimum-layer model root-mean-square resistivity error; smooth r.m.s., smooth model root-mean-square resistivity error]

\begin{tabular}{|c|c|c|c|c|c|c|c|c|}
\hline $\begin{array}{c}\text { Site } \\
\text { identifier }\end{array}$ & $\begin{array}{l}\text { Northing, } \\
\text { in feet }\end{array}$ & $\begin{array}{l}\text { Easting, } \\
\text { in feet }\end{array}$ & $\begin{array}{l}\text { Land-surface } \\
\text { elevation, } \\
\text { in feet }\end{array}$ & County & $\begin{array}{l}\text { DOI, } \\
\text { in feet }\end{array}$ & $\begin{array}{l}\text { MLM r.m.s., } \\
\text { in ohm-meters }\end{array}$ & $\begin{array}{l}\text { Smooth r.m.s., } \\
\text { in ohm-meters }\end{array}$ & $\begin{array}{l}\text { Acquisition } \\
\text { year }\end{array}$ \\
\hline CGG1 & 619,658 & $1,565,060$ & 2,819 & Logan & 1,578 & 1.403 & 1.194 & 2011 \\
\hline CGG2 & 710,781 & $1,680,430$ & 2,521 & Blaine & 1,578 & 2.369 & 1.704 & 2011 \\
\hline CGG3 & 755,845 & $1,615,650$ & 2,757 & Blaine & 1,578 & 0.325 & 0.735 & 2011 \\
\hline CGG4 & 795,948 & $1,715,440$ & 2,512 & Blaine & 1,335 & 0.353 & 0.303 & 2011 \\
\hline CGG5 & 833,235 & $1,605,900$ & 2,660 & Brown & 1,453 & 0.36 & 0.334 & 2011 \\
\hline CGG6 & 895,370 & $1,612,010$ & 2,722 & Brown & 1,453 & 0.345 & 0.292 & 2011 \\
\hline CGG7 & 942,590 & $1,720,300$ & 2,545 & Brown & 1,335 & 0.364 & 0.37 & 2011 \\
\hline CGG8 & 819,890 & $1,804,420$ & 2,423 & Loup & 1,227 & 0.283 & 0.276 & 2011 \\
\hline CGG9 & 730,256 & $1,741,840$ & 2,458 & Loup & 1,227 & 0.463 & 0.4 & 2011 \\
\hline CGG10 & 562,946 & $1,716,160$ & 2,646 & Custer & 1,125 & 0.535 & 0.437 & 2011 \\
\hline CGG11 & 642,151 & $1,732,320$ & 2,644 & Custer & 1,227 & 0.22 & 0.245 & 2011 \\
\hline CGG12 & 587,543 & $1,641,010$ & 3,026 & Custer & 1,578 & 0.716 & 0.475 & 2011 \\
\hline CGG13 & 882,821 & $1,257,210$ & 3,508 & Cherry & 1,335 & 0.424 & 0.343 & 2011 \\
\hline CGG14 & 701,211 & $1,237,790$ & 3,575 & Grant & 1,578 & 0.513 & 0.401 & 2011 \\
\hline CGG15 & 706,582 & $1,296,100$ & 3,421 & Hooker & 1,732 & 0.214 & 0.204 & 2009 \\
\hline $\mathrm{CN} 1$ & 787,332 & $1,223,580$ & 3,587 & Grant & 2,041 & 1.98 & 0.406 & 2009 \\
\hline $\mathrm{CN} 2$ & 765,055 & $1,300,110$ & 3,399 & Hooker & 1,886 & 0.766 & 0.796 & 2009 \\
\hline $\mathrm{CN} 3$ & 583,721 & $1,460,310$ & 3,044 & Logan & 1,732 & 0.638 & 0.546 & 2009 \\
\hline $\mathrm{CN} 4$ & 850,755 & $1,534,410$ & 2,760 & Cherry & 1,578 & 0.742 & 0.509 & 2009 \\
\hline CN5 & 898,768 & $1,532,730$ & 2,823 & Cherry & 1,732 & 0.836 & 0.627 & 2009 \\
\hline CN6 & 981,823 & $1,606,710$ & 2,627 & Brown & 863 & 0.703 & 0.489 & 2009 \\
\hline CN8 & $1,049,770$ & $1,545,540$ & 2,720 & Cherry & 1,453 & 0.595 & 0.496 & 2009 \\
\hline CN9 & 985,040 & $1,612,190$ & 2,621 & Brown & 1,578 & 0.481 & 0.407 & 2009 \\
\hline LL1 & 674,679 & $1,953,370$ & 2,163 & Valley & 945 & 0.736 & 0.648 & 2010 \\
\hline LL2 & 713,463 & $1,964,950$ & 2,138 & Garfield & 1,227 & 0.472 & 0.432 & 2010 \\
\hline LL3 & 742,801 & $1,931,490$ & 2,201 & Garfield & 1,335 & 0.7 & 0.639 & 2010 \\
\hline LL4 & 680,045 & $2,001,320$ & 2,188 & Greeley & 1,578 & 0.75 & 0.718 & 2010 \\
\hline LL5 & 659,843 & $1,986,900$ & 2,283 & Greeley & 1,578 & 0.878 & 0.718 & 2010 \\
\hline LL6 & 707,648 & $2,009,740$ & 2,037 & Wheeler & 1,453 & 0.397 & 0.419 & 2010 \\
\hline LL7 & 591,210 & $1,977,870$ & 2,122 & Valley & 1,227 & 1.36 & 1.165 & 2010 \\
\hline LL8 & 624,244 & $2,015,620$ & 2,098 & Greeley & 863 & 1.126 & 0.953 & 2010 \\
\hline LL9 & 666,355 & $2,041,590$ & 2,131 & Greeley & 1,335 & 0.662 & 0.571 & 2010 \\
\hline LL10 & 558,710 & $2,013,980$ & 1,926 & Howard & 863 & 0.423 & 0.384 & 2010 \\
\hline LL11 & 502,722 & $2,016,080$ & 1,985 & Howard & 479 & 0.41 & 0.342 & 2010 \\
\hline LL12 & 472,753 & $2,015,650$ & 1,989 & Howard & 650 & 0.404 & 0.406 & 2010 \\
\hline LL13 & 502,630 & $1,953,930$ & 2,186 & Sherman & 1,227 & 0.9 & 0.794 & 2010 \\
\hline LL14 & 433,666 & $1,892,430$ & 2,192 & Buffalo & 863 & 0.542 & 0.475 & 2010 \\
\hline LL15 & 560,276 & $1,924,580$ & 2,212 & Sherman & 1,030 & 0.464 & 0.399 & 2010 \\
\hline LL16 & 581,490 & $1,949,800$ & 2,191 & Valley & 787 & 0.311 & 0.36 & 2010 \\
\hline LL17 & 791,687 & $1,831,070$ & 2,360 & Loup & 1,453 & 1.094 & 0.873 & 2010 \\
\hline LL18 & 766,258 & $1,827,410$ & 2,292 & Loup & 1,125 & 0.523 & 0.548 & 2010 \\
\hline
\end{tabular}


Table 3. Summary by site of Elkhorn-Loup Model time-domain electromagnetic sounding locations and acquired resistivity data.-Continued

[Northing and easting in Nebraska State Plane coordinates; land-surface elevation in feet above National Geodetic Vertical Datum of 1929 (NGVD 29); DOI, estimated depth of investigation; MLM r.m.s., minimum-layer model root-mean-square resistivity error; smooth r.m.s., smooth model root-mean-square resistivity error]

\begin{tabular}{|c|c|c|c|c|c|c|c|c|}
\hline $\begin{array}{c}\text { Site } \\
\text { identifier }\end{array}$ & $\begin{array}{l}\text { Northing, } \\
\text { in feet }\end{array}$ & $\begin{array}{l}\text { Easting, } \\
\text { in feet }\end{array}$ & $\begin{array}{c}\text { Land-surface } \\
\text { elevation, } \\
\text { in feet }\end{array}$ & County & $\begin{array}{l}\text { DOI, } \\
\text { in feet }\end{array}$ & $\begin{array}{c}\text { MLM r.m.s., } \\
\text { in ohm-meters }\end{array}$ & $\begin{array}{l}\text { Smooth r.m.s., } \\
\text { in ohm-meters }\end{array}$ & $\begin{array}{l}\text { Acquisition } \\
\text { year }\end{array}$ \\
\hline LL19 & 720,956 & $1,836,210$ & 2,416 & Loup & 1,030 & 0.439 & 0.433 & 2010 \\
\hline LL20 & 689,741 & $1,810,020$ & 24,40 & Custer & 1,227 & 1.162 & 0.961 & 2010 \\
\hline LL21 & 619,666 & $1,838,190$ & 2,319 & Custer & 1,030 & 0.308 & 0.332 & 2010 \\
\hline LL22 & 575,615 & $1,835,500$ & 2,333 & Custer & 945 & 1.771 & 1.283 & 2010 \\
\hline LL23 & 571,551 & $1,791,820$ & 2,467 & Custer & 1,453 & 0.715 & 0.604 & 2010 \\
\hline LL24 & 543,306 & $1,834,790$ & 2,413 & Custer & 1,335 & 0.748 & 0.654 & 2010 \\
\hline LL25 & 490,508 & $1,835,850$ & 2,295 & Custer & 1,227 & 0.9 & 0.729 & 2010 \\
\hline LL26 & 683,565 & $1,877,120$ & 2,370 & Valley & 1,453 & 1.509 & 1.188 & 2010 \\
\hline LL27 & 648,907 & $1,901,310$ & 2,284 & Valley & 1,125 & 0.337 & 0.276 & 2010 \\
\hline SH1 & 703,139 & $1,949,260$ & 2,239 & Garfield & 1,125 & 0.474 & 0.387 & 2008 \\
\hline $\mathrm{SH} 2$ & 900,203 & $1,870,970$ & 2,326 & Holt & 1,030 & 0.478 & 0.401 & 2008 \\
\hline SH3 & 758,285 & $1,886,520$ & 2,356 & Garfield & 945 & 1.836 & 1.166 & 2008 \\
\hline SH4 & 648,822 & $1,856,070$ & 2,365 & Valley & 1,125 & 0.238 & 0.224 & 2008 \\
\hline SH5 & 765,610 & $1,795,980$ & 2,353 & Loup & 1,227 & 1.299 & 0.824 & 2008 \\
\hline SH6 & 647,381 & $2,044,570$ & 2,130 & Greeley & 1,030 & 0.34 & 0.325 & 2008 \\
\hline SH7 & 895,092 & $1,420,330$ & 3,039 & Cherry & 1,030 & 0.198 & 0.176 & 2008 \\
\hline SH8 & 597,630 & $1,400,990$ & 3,193 & McPherson & 945 & 0.201 & 0.136 & 2008 \\
\hline TDEM8 & 767,368 & $2,193,390$ & 2,000 & Antelope & 1,030 & 0.817 & 1.146 & 2011 \\
\hline TDEM9 & 810,352 & $2,196,470$ & 1,824 & Antelope & 1,125 & 0.641 & 0.525 & 2011 \\
\hline TDEM11 & 825,238 & $2,037,680$ & 2,035 & Holt & 1,335 & 0.416 & 0.488 & 2011 \\
\hline TDEM16 & 597,872 & $2,203,610$ & 1,698 & Nance & 1,030 & 0.645 & 1.093 & 2011 \\
\hline TDEM20 & 794,794 & $2,135,630$ & 1,950 & Antelope & 1,453 & 0.957 & 0.956 & 2011 \\
\hline TDEM41 & 628,152 & $2,260,090$ & 1,681 & Platte & 945 & 0.746 & 0.582 & 2011 \\
\hline TDEM42 & 829,643 & $2,251,240$ & 1,821 & Madison & 1,227 & 0.914 & 0.742 & 2011 \\
\hline TDEM43 & 622,377 & $2,202,250$ & 1,854 & Boone & 945 & 0.822 & 0.651 & 2011 \\
\hline TDEM44 & 711,724 & $2,200,300$ & 1,943 & Boone & 1,030 & 0.442 & 0.997 & 2011 \\
\hline TDEM48 & 585,432 & $2,074,960$ & 1,995 & Greeley & 1,453 & 1.017 & 1.607 & 2011 \\
\hline TDEM49 & 614,318 & $2,076,010$ & 2,001 & Greeley & 715 & 0.67 & 1.036 & 2011 \\
\hline TDEM68 & 597,213 & $2,135,340$ & 1,882 & Nance & 1,125 & 0.539 & 0.443 & 2011 \\
\hline TDEM69 & 621,494 & $2,138,750$ & 1,933 & Boone & 1,125 & 0.487 & 1.247 & 2011 \\
\hline TDEM70 & 850,756 & $2,248,890$ & 1,762 & Pierce & 1,125 & 0.373 & 0.364 & 2011 \\
\hline TDEM71 & 699,973 & $2,079,710$ & 2,108 & Wheeler & 1,227 & 0.557 & 0.458 & 2011 \\
\hline TDEM79 & 656,089 & $2,333,860$ & 1,651 & Platte & 715 & 0.51 & 0.418 & 2011 \\
\hline TDEM84 & 871,215 & $2,198,140$ & 1,847 & Antelope & 1,125 & 0.432 & 0.369 & 2011 \\
\hline TDEM86 & 941,520 & $2,240,480$ & 1,723 & Pierce & 787 & 0.24 & 0.606 & 2011 \\
\hline TDEM89 & 811,358 & $2,312,160$ & 1,560 & Madison & 787 & 0.448 & 0.38 & 2011 \\
\hline TDEM90 & 777,910 & $2,313,560$ & 1,704 & Madison & 863 & 0.46 & 0.899 & 2011 \\
\hline TDEM91 & 487,751 & $2,080,900$ & 1,880 & Howard & 945 & 0.357 & 0.822 & 2011 \\
\hline TDEM99 & 668,366 & $2,074,890$ & 2,014 & Greeley & 945 & 0.462 & 0.876 & 2011 \\
\hline TDEM140 & 888,185 & $1,968,590$ & 2,099 & Holt & 1,125 & 0.638 & 0.753 & 2011 \\
\hline TDEM156 & 702,988 & $2,109,730$ & 2,126 & Boone & 863 & 0.63 & 1.534 & 2011 \\
\hline
\end{tabular}


Table 3. Summary by site of Elkhorn-Loup Model time-domain electromagnetic sounding locations and acquired resistivity data.-Continued

[Northing and easting in Nebraska State Plane coordinates; land-surface elevation in feet above National Geodetic Vertical Datum of 1929 (NGVD 29); DOI, estimated depth of investigation; MLM r.m.s., minimum-layer model root-mean-square resistivity error; smooth r.m.s., smooth model root-mean-square resistivity error]

\begin{tabular}{|c|c|c|c|c|c|c|c|c|}
\hline $\begin{array}{c}\text { Site } \\
\text { identifier }\end{array}$ & $\begin{array}{l}\text { Northing, } \\
\text { in feet }\end{array}$ & $\begin{array}{l}\text { Easting, } \\
\text { in feet }\end{array}$ & $\begin{array}{l}\text { Land-surface } \\
\text { elevation, } \\
\text { in feet }\end{array}$ & County & $\begin{array}{l}\text { DOI, } \\
\text { in feet }\end{array}$ & $\begin{array}{c}\text { MLM r.m.s., } \\
\text { in ohm-meters }\end{array}$ & $\begin{array}{l}\text { Smooth r.m.s., } \\
\text { in ohm-meters }\end{array}$ & $\begin{array}{l}\text { Acquisition } \\
\text { year }\end{array}$ \\
\hline TDEM158 & 933,403 & $2,198,670$ & 1,747 & Antelope & 1,030 & 0.623 & 0.517 & 2011 \\
\hline TDEM177 & 916,371 & $2,067,880$ & 1,909 & Holt & 787 & 0.511 & 0.428 & 2011 \\
\hline TDEM178 & 900,104 & $2,061,040$ & 1,933 & Holt & 945 & 0.618 & 1.124 & 2011 \\
\hline TDEM209 & 835,359 & $2,196,680$ & 1,873 & Antelope & 1,125 & 1.144 & 0.82 & 2011 \\
\hline TDEM210 & 875,958 & $2,242,030$ & 1,709 & Pierce & 1,030 & 0.457 & 0.377 & 2011 \\
\hline TDEM211 & 906,612 & $2,279,380$ & 1,723 & Pierce & 945 & 0.774 & 0.625 & 2011 \\
\hline TDEM212 & 923,617 & $1,951,490$ & 2,130 & Holt & 1,030 & 1.073 & 0.872 & 2011 \\
\hline TDEM218 & 598,191 & $2,013,350$ & 2,045 & Greeley & 1,030 & 0.533 & 0.448 & 2011 \\
\hline TDEM223 & 799,172 & $1,198,470$ & 3,728 & Grant & 1,732 & 0.659 & 0.521 & 2011 \\
\hline TDEM224 & 824,062 & $1,193,740$ & 3,659 & Grant & 1,732 & 0.555 & 0.457 & 2011 \\
\hline TDEM228 & 777,070 & $1,187,490$ & 3,678 & Grant & 1,886 & 0.499 & 0.751 & 2011 \\
\hline TDEM232 & 782,646 & $1,286,340$ & 3,436 & Hooker & 1,732 & 0.592 & 0.462 & 2011 \\
\hline UE1 & 947,419 & $1,956,570$ & 2,071 & Holt & 1,335 & 0.815 & 0.696 & 2010 \\
\hline UE2 & 915,620 & $1,950,450$ & 2,131 & Holt & 1,335 & 0.566 & 0.47 & 2010 \\
\hline UE3 & 899,780 & $1,846,380$ & 2,379 & Rock & 1,453 & 0.505 & 0.45 & 2010 \\
\hline UE4 & 925,047 & $1,877,700$ & 2,250 & Holt & 1,227 & 0.475 & 0.484 & 2010 \\
\hline UE5 & 957,904 & $1,875,210$ & 2,209 & Holt & 945 & 0.79 & 0.673 & 2010 \\
\hline UE6 & 944,357 & $1,956,270$ & 2,083 & Holt & 1,227 & 0.928 & 0.673 & 2010 \\
\hline UE7 & 881,159 & $1,958,390$ & 2,118 & Holt & 1,227 & 1.272 & 1.04 & 2010 \\
\hline UE8 & 854,451 & $1,954,880$ & 2,172 & Holt & 1,335 & 0.58 & 0.49 & 2010 \\
\hline UE9 & 840,477 & $2,001,090$ & 2,075 & Holt & 1,227 & 0.665 & 0.568 & 2010 \\
\hline UE10 & 871,712 & $2,006,140$ & 2,050 & Holt & 863 & 0.935 & 2.263 & 2010 \\
\hline UE11 & $1,003,050$ & $1,863,850$ & 2,160 & Holt & 1,125 & 0.368 & 0.278 & 2010 \\
\hline UL1 & 936,364 & $1,307,910$ & 3,297 & Cherry & 1,732 & 0.941 & 0.769 & 2010 \\
\hline UL2 & 932,214 & $1,272,210$ & 3,379 & Cherry & 1,886 & 0.857 & 0.706 & 2010 \\
\hline UL3 & 907,558 & $1,312,120$ & 3,385 & Cherry & 2,041 & 1.319 & 1.074 & 2010 \\
\hline UL4 & 881,714 & $1,298,340$ & 3,416 & Cherry & 1,732 & 0.857 & 0.716 & 2010 \\
\hline UL5 & 900,378 & $1,313,570$ & 3,372 & Cherry & 2,041 & 0.791 & 0.706 & 2010 \\
\hline UL6 & 779,134 & $1,417,440$ & 3,103 & Thomas & 2,195 & 1.157 & 0.976 & 2010 \\
\hline UL7 & 801,809 & $1,428,440$ & 3,078 & Thomas & 1,732 & 0.635 & 0.58 & 2010 \\
\hline UL8 & 800,500 & $1,416,730$ & 3,081 & Thomas & 1,732 & 0.544 & 0.488 & 2010 \\
\hline UL9 & 743,101 & $1,536,170$ & 2,807 & Thomas & 1,732 & 0.716 & 0.459 & 2010 \\
\hline UL10 & 767,240 & $1,509,760$ & 2,874 & Thomas & 1,578 & 0.772 & 0.722 & 2010 \\
\hline UL11 & 714,076 & $1,553,040$ & 2,763 & Thomas & 1,578 & 0.815 & 0.783 & 2010 \\
\hline UL12 & 812,076 & $1,511,000$ & 2,937 & Thomas & 1,453 & 0.379 & 0.328 & 2010 \\
\hline UL13 & 91,4058 & $1,457,900$ & 2,929 & Cherry & 1,578 & 0.461 & 0.408 & 2010 \\
\hline UL14 & 88,3009 & $1,451,770$ & 2,966 & Cherry & 1,886 & 0.694 & 0.555 & 2010 \\
\hline UL15 & 70,5348 & $1,439,260$ & 3,105 & Thomas & 1,578 & 0.778 & 0.654 & 2010 \\
\hline UL16 & 69,6800 & $1,472,010$ & 2,994 & Thomas & 1,578 & 0.733 & 0.678 & 2010 \\
\hline UL18 & 75,1838 & $1,354,880$ & 3,258 & Hooker & 1,578 & 0.754 & 0.579 & 2010 \\
\hline UL19 & 74,6562 & $1,450,500$ & 3,039 & Thomas & 1,886 & 0.646 & 0.562 & 2010 \\
\hline
\end{tabular}




\section{Time-Domain Electromagnetic (TDEM) Data Analysis}

Data analysis for all soundings consisted of data format conversion, statistical analysis and averaging, data inversion, model assessment, and forward modeling. Data were processed and inverted using the SiTEM data processing and Single-Site Electromagnetics Data Inversion (SEMDI) software packages (Auken and Nebel, 2001). The SEMDI inversion was chosen because it permits full waveform specification, the modeling of system filters, and the incorporation of data errors. Furthermore, it provides error bounds on inverted parameters (layer thicknesses and resistivities). Data were inverted for two end-member model classes: minimumlayer inverse models and 20-layer smooth, or Occam-style, inverse models (Constable and others, 1987). The former class of models seeks to fit the measured data with as few distinct layers as possible, whereas the latter seeks to fit the data with a large number of thin layers of fixed thickness under the assumption that resistivity varies gradually between adjacent layers. The fit of the model to the data is evaluated by comparing the model's forward response, or synthetic "measured" data, to the data. Minimum-layer models are more appropriate in settings where abrupt changes in resistivity are expected, whereas smooth models are more realistic when gradational changes are expected. Independent knowledge from geologic mapping, borehole lithology, and geophysical borehole logs typically are used to evaluate which model class is more applicable for interpreting subsurface structure at a specific study area.

The DOI estimates at each site were calculated using the approach of Christiansen and Auken (2010). Based on a linear sensitivity analysis, this approach provided an estimate of the maximum model depth that was constrained by the measured data. These DOI estimates are based on a specified sensitivity threshold, and are viewed as relative, rather than absolute. Within the ELM study area, the average DOI of TDEM soundings was $1,288 \mathrm{ft}(393 \mathrm{~m})$, and values ranged from 479 to $2,195 \mathrm{ft}$ (146 to $669 \mathrm{~m}$ ). The DOI estimate for each TDEM sounding is presented in table 3 .

The modeling and inversion of TDEM data are commonly one-dimensional (1-D). This assumption is reasonable given the nature of the regional geology (laterally expansive sedimentary deposits), the compact footprint of soundings by the TDEM method, and the limited depth of investigation. Furthermore, lithologic and stratigraphic logs from surrounding test holes show lateral correlation across the study area. Finally, with the exception of the 2008 soundings, where outof-loop data were not recorded, joint inversion of the in-loop and out-of-loop data were consistent with a 1-D subsurface resistivity structure.

Geophysical methods, including TDEM, exhibit a degree of model non-uniqueness. As such, available ground truth from test-hole logs was incorporated during and following modeling and inversion of TDEM data, and provided important guidance during interpretations. The non-uniqueness stems from inherent resolution limitations, and incomplete and inexact data. Thus, for any set of measured data, a range of models can typically be constructed that adequately fit the data. For most electrical methods, equivalence exists between models with equal conductance (depth-integrated conductivity). Thus, for example, a model with resistivity of $10 \mathrm{ohm}-\mathrm{m}$ and a $164-\mathrm{ft}-(50-\mathrm{m}-)$ thick layer produces a nearly identical forward response as a model with a resistivity of $2 \mathrm{ohm}-\mathrm{m}$ and a 33-ft- (10-m-) thick layer. Additionally, the TDEM method has difficulty resolving resistive layers because of the lowcurrent densities induced within them as compared to conductive layers.

\section{Hydrostratigraphic Interpretation of Test-Hole and Surface Geophysical Data}

\section{Test-Hole Lithologic and Borehole Geophysical Logs}

Generalized lithologic descriptions and selected borehole geophysical logs for the six test holes are presented in figures 3 through 8 . An example test hole is shown in figure 3 with generalized lithologic description and borehole geophysical logs. Logs from all other test holes are located in the "Supplemental Data" section of this report. Borehole geophysical logs include data for long- and short-normal resistivity, natural gamma activity, and spontaneous potential. Examination of the resistivity data from the borehole logs in comparison with the test-hole lithologic data led to the following hydrostratigraphic interpretations.

The base of aquifer is indicated in the generalized lithologic log by the top of the siltstone unit of the Brule or the top of the Pierre Shale. When a complete geophysical log was collected, the long- and short-normal resistivity logs indicated the base of the High Plains aquifer system by sharp contrasts in resistivity between the Brule or Pierre Shale and the overlying units. Examining the long- and short-normal resistivity, the resistivity of sediments overlying the Brule ranged from less than 50 to greater than $250 \mathrm{ohm}-\mathrm{m}$. Within these sediments, resistivity for the Ogallala (units containing rootlets) ranged between 50 and $200 \mathrm{ohm}-\mathrm{m}$ (and more typically between 75 and $150 \mathrm{ohm}-\mathrm{m}$ ), with higher resistivity values indicating the presence of coarser deposits or a greater degree of cementation of the sandstone units. Coarse sand and gravel deposits typically had resistivity ranges from $150 \mathrm{ohm}-\mathrm{m}$ to more than $250 \mathrm{ohm}-\mathrm{m}$. In contrast, the resistivity of the Brule typically was less than $25 \mathrm{ohm}-\mathrm{m}$ and, in most cases, less than $15 \mathrm{ohm}-$ $\mathrm{m}$, and the underlying Pierre Shale had resistivity typically less that $15 \mathrm{ohm}-\mathrm{m}$.

Other logs provided further support for the base-of-aquifer interpretation. Natural gamma logs indicated an increase in activity near the base of the aquifer because of increased 


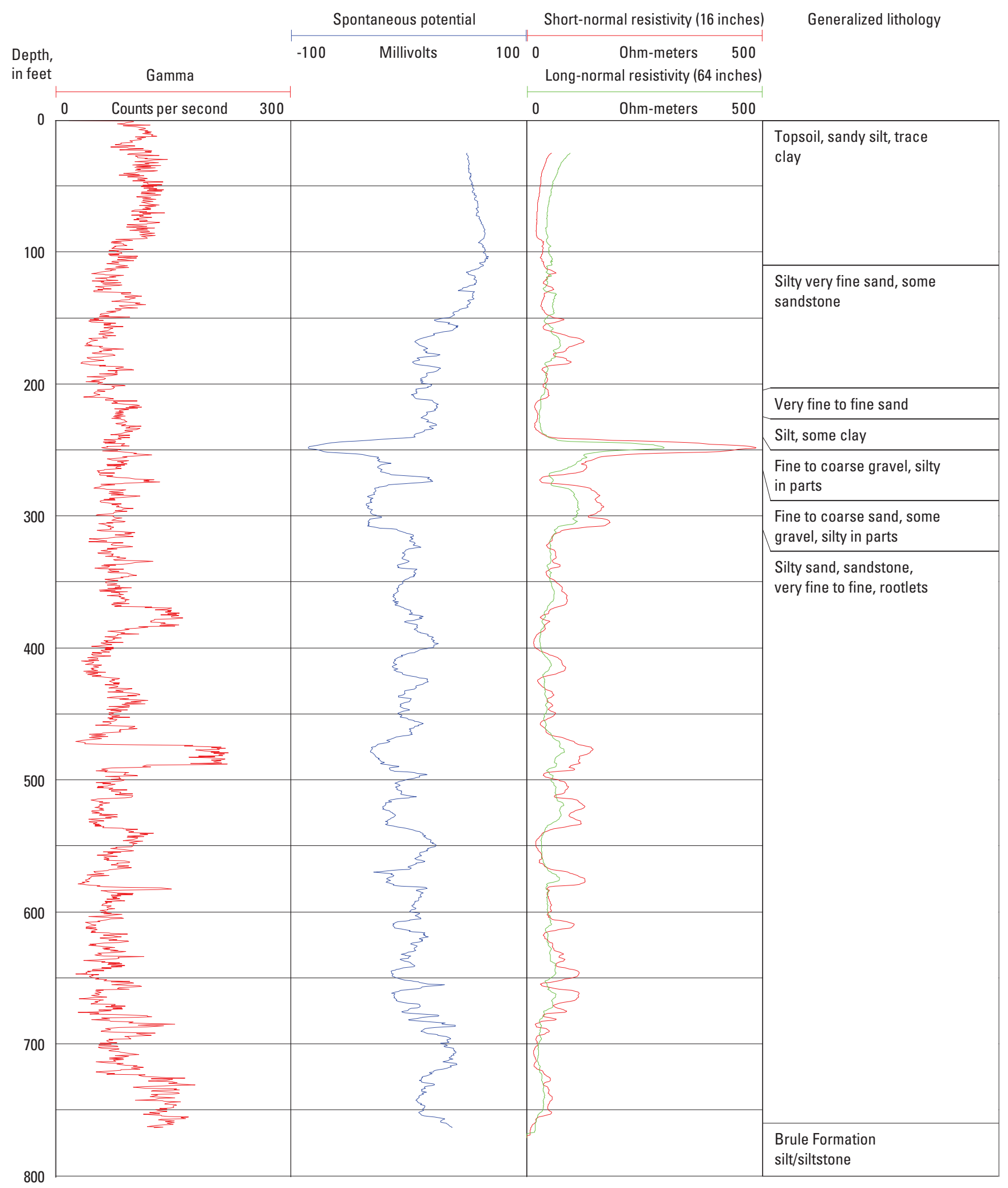

Figure 3. Composite of generalized lithologic description and geophysical logs for test hole 1-LL-10, Custer County, Nebraska. Short-normal resistivity, in ohm-meters; long-normal resistivity, in ohm-meters; natural gamma activity, in counts per second; spontanenous potential, in millivolts. 
volcanic ash content of the Brule or clay content in the Pierre Shale. Spontaneous-potential logs can indicate the degree to which the drilling fluid invaded the formation, and the relative impermeability of the Brule and Pierre Shale typically resulted in a positive deflection indicating that minimal drilling fluid invaded this interval.

While drilling test hole 2-LL-10, a hard, sandy claystone was encountered at 805 to $807 \mathrm{ft}$ ( 245 to $246 \mathrm{~m}$ ) below land surface, which plugged the drill bit and caused a loss in circulation of drilling fluid. Consequently, the drill stem had to be promptly removed and a geophysical log was collected immediately. Because the hole was only drilled $2 \mathrm{ft}(0.6 \mathrm{~m})$ into the claystone unit, the geophysical log did not measure any of the physical properties in the claystone unit, making an interpretation of the base of aquifer difficult. Cast (2000) reported that in test hole 12-A-66, approximately 6 miles (mi) [10 kilometers $(\mathrm{km})]$ northwest (not shown on map), a thin layer of Brule was drilled before the Chadron was encountered. Although no Brule cuttings were noted in the cuttings from 2-LL-10, it is possible that the sandy claystone encountered was another eastern outlier of the Chadron. For this report, the authors have picked the base of aquifer at the top of this claystone unit at 805 feet $(245 \mathrm{~m})$ below land surface.

Differences in the elevation of the base of the principal aquifer for test holes drilled after the completion of Scientific Investigations Map 3042 (McGuire and Peterson, 2008) were computed by subtracting the estimated base-of-aquifer elevation from the drilled (table 2). The range of differences between the elevations of the drilled base of aquifer and the previously estimated base of aquifer (McGuire and Peterson, 2008) was from -131 to $34 \mathrm{ft}$ (-40 to $10 \mathrm{~m}$ ). The upper end of this range is less than those previously reported for the western part of the ELM area (Hobza and others, 2011), where deeper paleochannels were eroded into the Brule.

Researchers have indicated that Pliocene-age or younger gravel covers much of the ELM area (Diffendal and others, 2008; Souders, 2000; Swinehart and Diffendal, 1989). Sand and gravel deposits overlaid intervals of sandstone containing rootlets in all test holes. Other researchers, including Souders (2000), have noted a Plio-Pleistocene gravel unit that ranged from 45 to $165 \mathrm{ft}$ ( 13 to $50 \mathrm{~m}$ ) in thickness and that frequently was interbedded with silt or clay. The sand and gravel layers encountered in test holes in Custer County were thicker than those encountered by previous drilling in the Upper Loup NRD (Hobza and others, 2011).

\section{TDEM Resistivity Models}

Figures 9 through 70 present the measured data from the 123 utilized (1 TDEM site not used, discussed later in this section) TDEM stations together with best-fit inverse models. An example sounding is shown in figures $9 A$ and $9 B$. All other soundings data are located in the "Supplemental Data" section of this report. At each station, the left panel $(A)$ shows the measured data (error bars) as well as the forward responses of the two inverse models (curves), whereas the right panel $(B)$ shows the best-fit minimum-layer (red) and smooth (blue) inverse model. For all soundings, the central-loop data are plotted as apparent resistivity. Out-of-loop data for the secondary vertical magnetic field, which were collected for all 2009-2011 soundings, are plotted (when used for interpretation) as the time derivative of the induced magnetic field $(d B / d t)$ in volts per square meter (upper set of curves, see figure captions for details on plots). In most cases, the model response falls within the variance of the measured data; exceptions are noted for the out-of-loop data collected above conductive ground, which demonstrate a sign change at early times. This sign change is associated with the passage of time for peak current density to travel outward from the transmitter loop, and is extremely sensitive to the position of the receiver relative to the transmitter loop.

In general, the low root-mean-square (r.m.s.) errors for the minimum layer and smooth models (table 3 ), and small error bounds on the data (figs. 9-70), even into later times, yielded high-quality data. This reflects the low density of human population within the survey area, and consequent low level of cultural noise (power lines, pipelines, well pumps, electric fences). A small number of soundings (eight) suffered from cultural noise, identified as oscillatory behavior in the vertical component of the secondary magnetic field $(d B / d t)$ decay curves. At these locations, data quality was compromised at late times; however, removal of the late-time data resulted in interpretable sounding data, albeit with a reduced DOI. One sounding (UL17) proved to be completely contaminated by cultural noise; the data were found to be inconsistent with nearby TDEM soundings as well as lithologic/ stratigraphic logs from nearby test holes. Consequently, this sounding was removed from the dataset.

The resistivity models, in most cases, reproduced the measured data to within the estimated uncertainty of measurement r.m.s. error of less than $1 \mathrm{ohm}-\mathrm{m}$. The r.m.s. errors for all soundings for the two models are indicated in table 3. In general, the r.m.s. error is slightly larger for the minimumlayer models than for the smooth models, reflecting the greater difficulty in fitting the data with a small number of model parameters. R.m.s. errors (table 3 ) were, however, similar for the smooth and minimum-layer models, suggesting that the minimum-layer parameterization can adequately represent the subsurface resistivity structure, and by inference, the hydrostratigraphy. This is consistent with the previously known geologic history, which includes a number of sharp unconformities associated with erosion and changes from marine to alluvial to eolian deposition.

Each minimum-layer model is the result of an unregularized, parameterized inversion and, as such, error bounds on the inverted parameters (layer thicknesses, depth-to-layer interfaces, and resistivities) can be calculated from a model covariance matrix output by the inversion (Aarhus Hydrogeophysics Group, 2008). The resulting standard errors define an asymmetrical error window, where the upper and lower bounds of parameter $p$ are calculated by equations 1 and 2 : 


$$
\begin{gathered}
p_{u}=p *\left(1+\sigma_{p}\right) \\
p_{l}=\frac{p}{1+\sigma_{p}}
\end{gathered}
$$

where

$$
\begin{aligned}
& p \quad \text { is the parameter (resitivity, thickness, or } \\
& \text { depth) }
\end{aligned}
$$

$$
\sigma_{p}=e^{\sqrt{\operatorname{cov}(p, p)}}-1
$$

where

$$
\begin{aligned}
e & \text { is an exponential } \\
\operatorname{cov}(p, p) & \text { is the model covariance matrix of parameter } p .
\end{aligned}
$$

The resulting parameter bounds, in particular the bounds on layer-interface depths, are important in assessing the relative uncertainty of geophysical and test-hole constraints on aquifer and aquifer-confining-unit (ACU) stratigraphy. Model-derived constraints on stratigraphic boundaries, together with their associated upper and lower bounds, discussed in the next section, are provided in spreadsheet format that can be accessed on the Internet at http://pubs.usgs.gov/of/2012/1227/.

\section{Stratigraphic Interpretation of TDEM-Based Resistivity Models}

To aid in assigning stratigraphy to the minimum-layer TDEM resistivity models, a comparison was made of each model to lithologic and stratigraphic logs from all test holes within roughly $6 \mathrm{mi}(10 \mathrm{~km})$ of the TDEM sounding. In total, more than 435 test holes were examined in relation to the TDEM resistivity models. This comparison proved useful in
SITE UE11

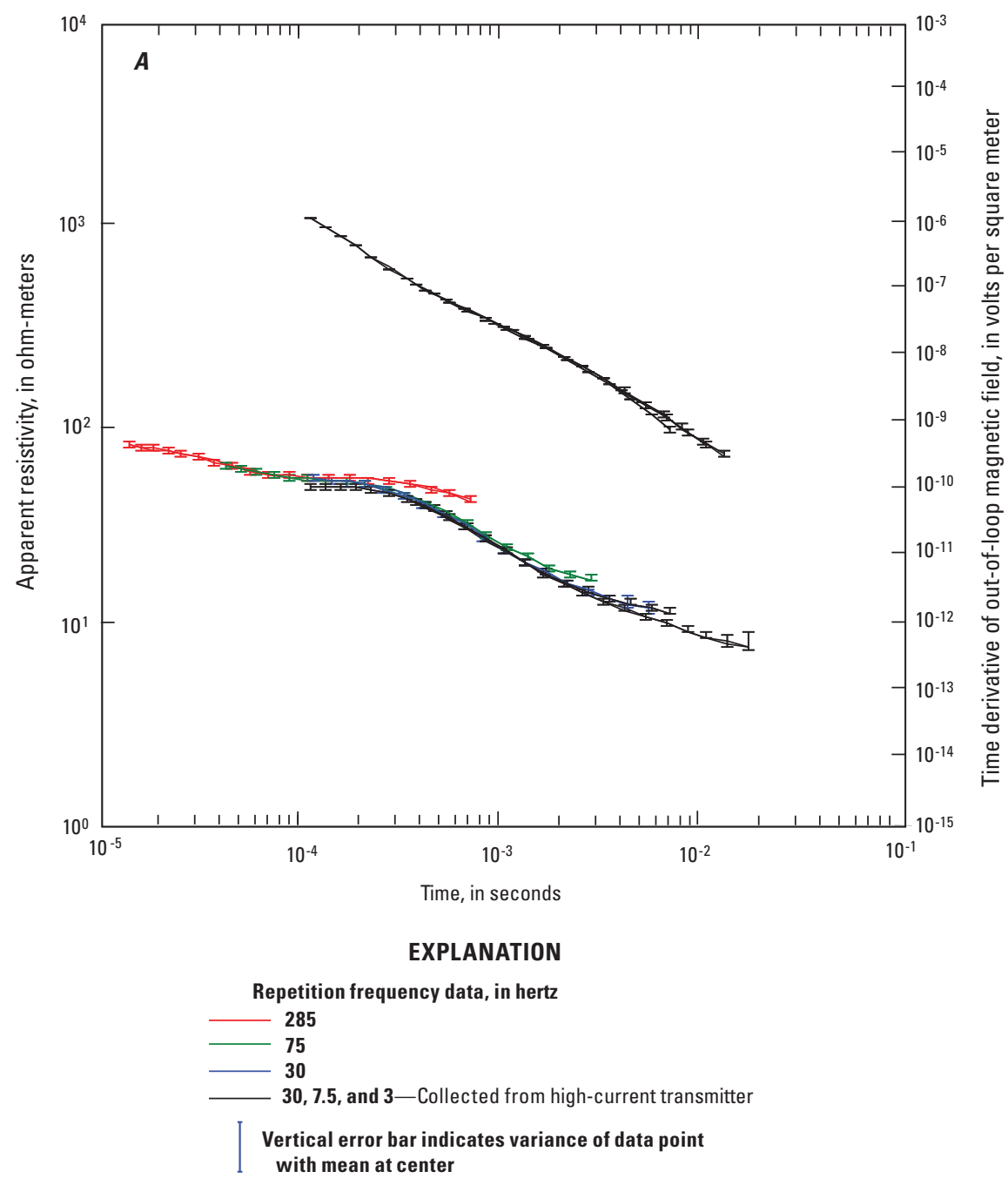

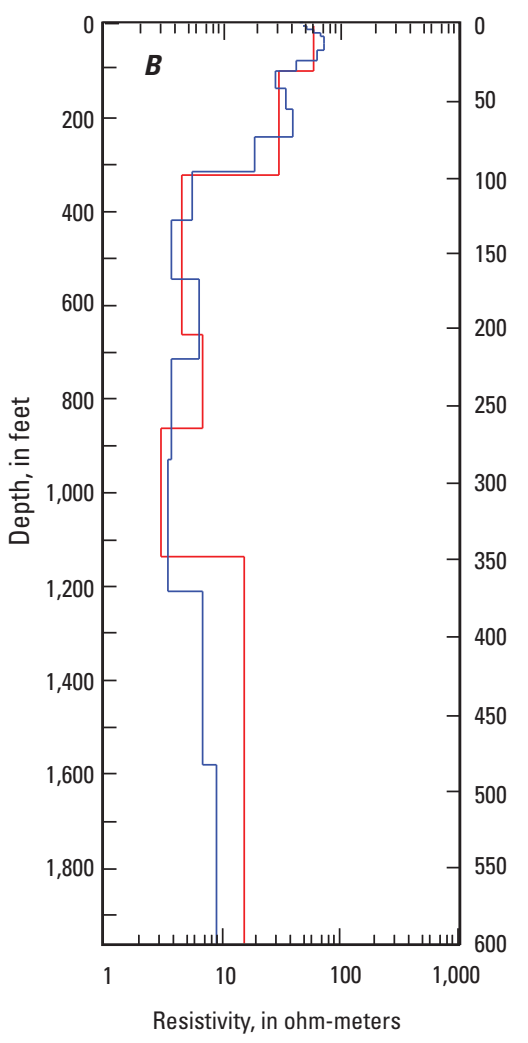

EXPLANATION

Best-fit minimum-layer model

Figure 9. Relations between $A$, central-loop resistivity, out-of-loop vertical magnetic field (upper set of curves time-derivative, right axis), and elapsed time after primary current turnoff; and $B$, depth below land surface and subsurface resistivity modeled from timedomain electromagnetic sounding for site UE11. 
identifying characteristic resistivity ranges and thickness patterns for each stratigraphic unit, in addition to spatial trends in the elevation and depth to stratigraphic interfaces. An example of the type of comparison made is shown in figure 71. A limitation of CSD test-hole data, however, is that few boreholes extend beyond the base of the High Plains aquifer system, defined generally by the Brule in the west, the Pierre Shale in the east, and the Niobrara along the eastern edge of the ELM study area. To examine the correlation with deeper stratigraphic layers, more than 93 deep boreholes within the Nebraska Oil and Gas Conservation Commission (2012) database were examined. These wells complement the test-hole database because they typically contain stratigraphic information only for the Pierre Shale and below. These comparison studies led to further modeling of subsets of the TDEM data; the final stratigraphic picks in table 4 and the online spreadsheet in the Supplemental Data are the result of several additional rounds of modeling and test-hole comparison.

The resulting stratigraphic picks (table 4 ) include the base of Quaternary deposits $\left(\mathrm{B}_{\mathrm{QT}}\right)$, the top and base of PlioPleistocene gravel $\left(\mathrm{T}_{\mathrm{PP}} / \mathrm{B}_{\mathrm{PP}}\right)$, the top and base of the Ogallala $\left(\mathrm{T}_{\mathrm{OG}} / \mathrm{B}_{\mathrm{OG}}\right)$, and the top of the ACU (Brule, Pierre Shale, Niobrara, or Carlile Shale). In addition, stratigraphy below the ACU can often be identified (Carlile Shale or Dakota Sandstone) and, for sites where such units were distinguished, is provided in the spreadsheet available at http://pubs.usgs.gov/ $o f / 2012 / 1227 /$. Not all stratigraphic units are present at all sounding locations, and the ACU varies throughout the ELM study area from the Brule in the west to Pierre Shale, Niobrara, or Carlile Shale in the east. Even where present, individual stratigraphic units could not always be picked if sufficient resistivity contrast was not evident. This is particularly true for the Miocene and younger deposits, the thickness and resistivity of which are highly variable throughout the ELM study area. This reflects the complex fluvial deposition pattern of Ogallala and younger sediments relative to older marine and eolian deposits. In general, the base of aquifer (top of the $\mathrm{ACU}$ ) is one of the best-resolved interfaces from the resistivity models. Estimates of the base-of-aquifer elevation are in good accordance with those from existing test-hole data.

The TDEM data generally support four- to nine-layer models for resistivity stratigraphy. The modeled resistivity results reflect the eastward thinning of Miocene-age and older stratigraphic units, and generally allow confident interpretation of the accompanying change in the stratigraphic unit forming the ACU. TDEM resistivity models from the western ELM study area (Cherry, Grant, Hooker, Thomas, Arthur, McPherson, and Logan Counties) exhibit decreasing resistivity with increasing depth below about 300-400 ft (91-120 m) below land surface. In many cases, these models indicated a thick Ogallala sequence atop the low-resistivity $(12.6 \pm 4.9 \mathrm{ohm}-\mathrm{m})$ Brule or Pierre Shale. The underlying Pierre Shale ( $4.7 \pm 1.5$ ohm-m) was identified except in parts of Cherry, Grant, Hooker, and McPherson Counties, where a thick Tertiary section limited the utility of TDEM resistivity models to resolve stratigraphy beneath the Brule. The central ELM study area (Blaine,
Brown, Custer, Loup, and Rock Counties) is characterized by a thin or absent Brule and eastward thinning Pierre Shale; at most locations, the underlying Niobrara (20.7 $\pm 17.3 \mathrm{ohm}-\mathrm{m})$ also was distinguished. Within the eastern ELM study area, the Brule is absent, except in parts of Holt and Antelope Counties, where test-hole data define an east-west trending strip of Brule in the subsurface. Along the easternmost edge of the ELM study area, no rocks of Miocene or Oligocene age (Ogallala and Brule) are preserved, and the Pierre Shale and Niobrara also are absent in several locations. This part of the ELM study area contains the oldest geologic structure, and a number of TDEM resistivity models allowed the tops of the Carlile Shale $(6.8 \pm 2.5$ ohm-m) and Dakota Sandstone $(21.4 \pm 9.1 \mathrm{ohm}-$ $\mathrm{m})$ to be distinguished.

The TDEM resistivity models also provided information regarding the distribution of Plio-Pleistocene (PP) gravel deposits within the study area. These deposits are typically more resistive (about $100 \mathrm{ohm}-\mathrm{m}$ ) than the overlying Quaternary sediments or the underlying Ogallala. The average thickness of the PP deposits in the ELM study area is $100 \mathrm{ft}$ $(30 \mathrm{~m})$, although in many cases the PP cannot be uniquely distinguished from the overlying Quaternary deposits and/or the underlying Ogallala Formation using only TDEM soundings. In such cases, the estimated PP thickness is likely an overestimate. PP deposits are unevenly distributed throughout the ELM study area; however, five regions (fig. 72) with PP deposits can be broadly identified from the TDEM-based resistivity models. In the southwest, two small regions are observed: one in Grant and Hooker Counties, and the other in Thomas, Logan, and potentially McPherson Counties. These regions are separated by several TDEM soundings without an identifiable PP layer. Furthermore, this separation is in agreement with Swinehart and Diffendal (1989), who identified areas of thin or absent gravels. Further east, a largely contiguous region includes eastern Loup County; much of Garfield, Valley, and Sherman Counties; and smaller parts of Wheeler and Greeley Counties. A smaller region of PP deposits was evident in south-central Holt County. Finally, at the northeast edge of the ELM study area, PP deposits are inferred near the intersection of Antelope, Pierce, and Madison Counties.

\section{Evaluation of Stratigraphic Interpretation of TDEM-Based Resistivity Models}

For this study, a subset of all the TDEM sites was collected near existing or planned test holes. These sites, referred to hereinafter as quality-control (QC) sites, were located across the ELM area. Efforts were made to collect TDEM data as close as possible to the test hole, but often the TDEM sounding was up to $0.31 \mathrm{mi}(0.5 \mathrm{~km})$ away because of the proximity of cultural noise. For other soundings, contacts between various stratigraphic intervals (table 4) were identified, where distinguishable, based on the minimumlayer TDEM resistivity-model results presented in figures 9 through 70 . The depths of the stratigraphic picks were 


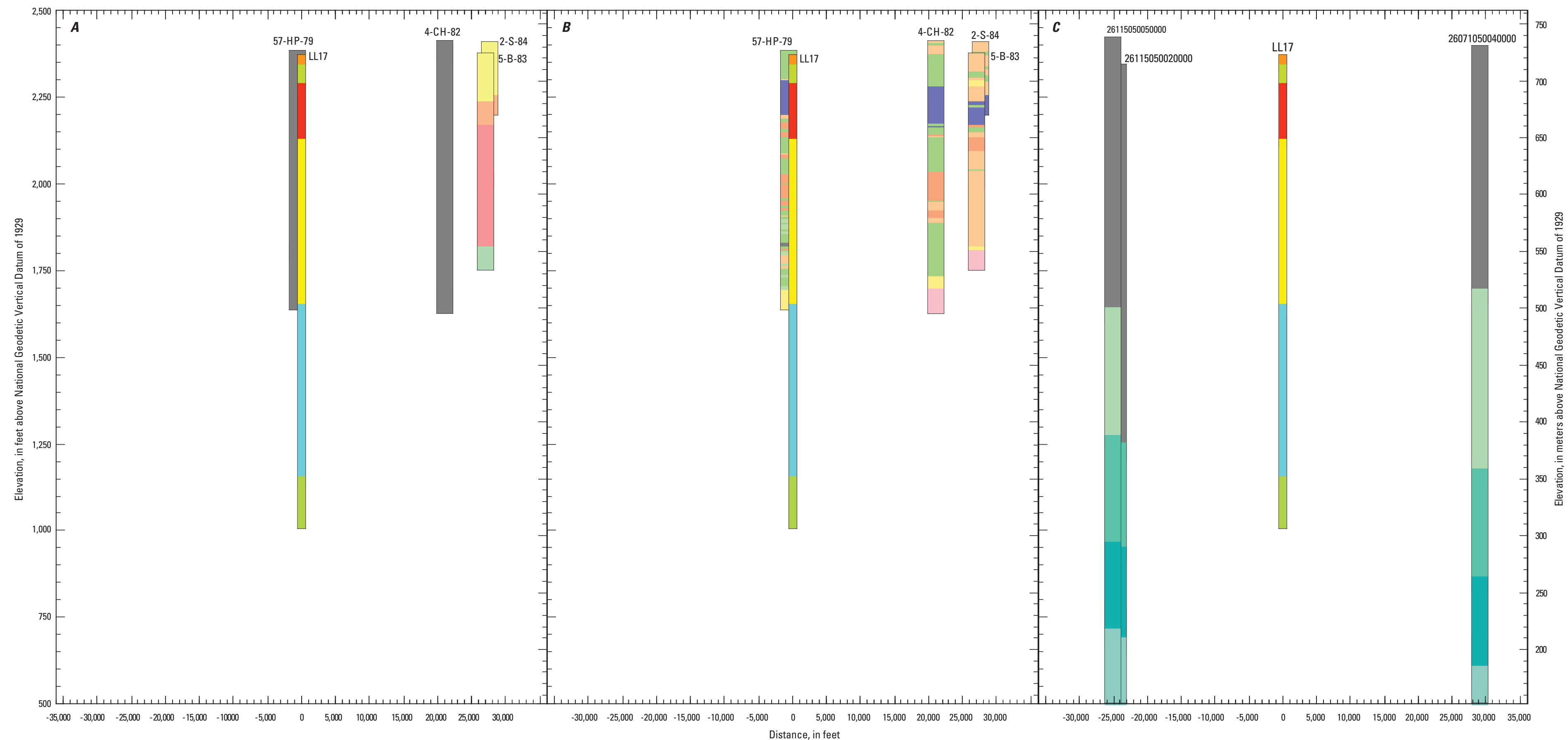

Minimum-layer model resistivity, in ohm-meters for time-domain electromagnetic (TDEM) sounding LL17
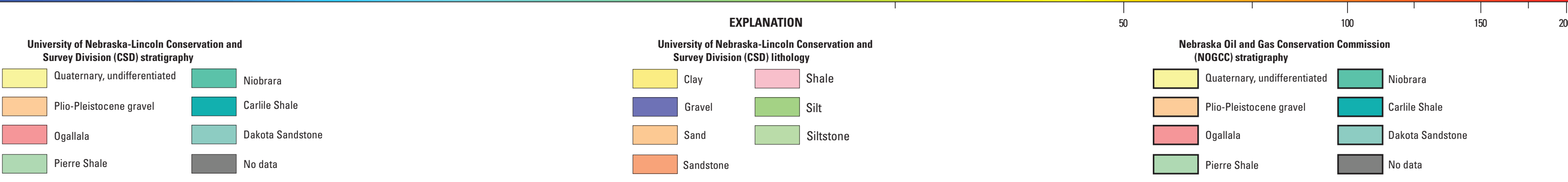

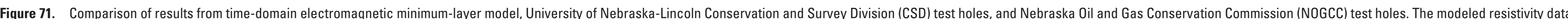
collected in 2010 from time-domain electromagnetic (TDEM) sounding site 417 are compared to $A$, CSD test-hole stratigraphy, B, CSD lithologic descriptions, and $C$, NOGCC test-hole stratigraphy. 
Table 4. Stratigraphic contacts resulting from minimum-layer time-domain electromagnetic models of sounding sites, Elkhorn-Loup Model study area, 2010.

[Elevation, land-surface elevation above National Geodetic Vertical Datum of 1929 (NGVD 29); all depths given in feet below land surface; $\mathrm{T}_{\mathrm{QT}}$, top of Quaternary; $\mathrm{B}_{\mathrm{QT}}$, depth to bottom of Quaternary; $\mathrm{T}_{\mathrm{PP}}$, depth to top of Plio-Pleistocene gravel; $\mathrm{B}_{\mathrm{PP}}$, depth to bottom of Plio-Pleistocene gravel, italicized where top of unit is not distinguishable with overlying Quaternary units; $\mathrm{T}_{\mathrm{OG}}$, depth of top of Ogallala; $\mathrm{B}_{\mathrm{OG}}$, depth of bottom of Ogallala; $\mathrm{T}_{\mathrm{ACU}}$, depth to top of aquifer confining unit; $\mathrm{ACU}$, aquifer confining unit; ND, depth of contact not determined; BR, Brule; --, contact not present; PI, Pierre Shale; NI, Niobrara Formation; CA, Carlile Shale]

\begin{tabular}{|c|c|c|c|c|c|c|c|c|c|}
\hline $\begin{array}{c}\text { Site } \\
\text { identifier }\end{array}$ & Elevation & $T_{0 T}$ & $\mathbf{B}_{0 \mathrm{~T}}$ & $\mathbf{T}_{\mathrm{PP}}$ & $\mathbf{B}_{\mathrm{PP}}$ & $T_{0 G}$ & $B_{0 G}$ & $T_{A C U}$ & ACU \\
\hline CGG1 & 2,819 & 0 & ND & ND & 152 & 152 & 754 & 754 & BR \\
\hline CGG2 & 2,521 & 0 & 166 & -- & -- & 166 & 474 & 474 & BR \\
\hline CGG3 & 2,757 & 0 & 118 & -- & -- & 118 & 855 & 855 & BR \\
\hline CGG4 & 2,512 & 0 & 54 & -- & -- & 54 & 710 & 710 & BR \\
\hline CGG5 & 2,660 & 0 & 117 & -- & -- & 117 & 693 & 693 & BR \\
\hline CGG6 & 2,722 & 0 & 52 & -- & -- & 52 & 668 & 668 & BR \\
\hline CGG7 & 2,545 & 0 & 200 & -- & -- & 200 & 543 & 543 & PI \\
\hline CGG8 & 2,423 & 0 & 136 & 136 & 247 & 247 & 616 & 616 & $\mathrm{BR}$ \\
\hline CGG9 & 2,458 & 0 & 67 & -- & -- & 67 & 578 & 578 & BR \\
\hline CGG10 & 2,646 & 0 & 322 & -- & -- & 322 & 912 & 912 & PI \\
\hline CGG11 & 2,644 & 0 & 187 & -- & -- & 187 & 868 & 868 & PI \\
\hline CGG12 & 3,026 & 0 & 190 & -- & -- & 190 & 1,163 & 1,163 & $\mathrm{BR}$ \\
\hline CGG13 & 3,508 & 0 & 98 & -- & -- & 98 & 758 & 758 & BR \\
\hline CGG14 & 3,575 & 0 & ND & ND & 347 & 347 & 921 & 921 & BR \\
\hline CGG15 & 3,421 & 0 & 97 & -- & -- & 97 & 860 & 860 & BR \\
\hline $\mathrm{CN} 1$ & 3,587 & 0 & ND & ND & 166 & 166 & 1,145 & 1,145 & BR \\
\hline $\mathrm{CN} 2$ & 3,399 & 0 & 158 & 158 & 312 & 312 & 1,042 & 1,042 & $\mathrm{BR}$ \\
\hline $\mathrm{CN} 3$ & 3,044 & 0 & 161 & -- & -- & 161 & 760 & 760 & $\mathrm{BR}$ \\
\hline $\mathrm{CN} 4$ & 2,760 & 0 & 68 & -- & -- & 68 & 553 & 553 & BR \\
\hline CN5 & 2,823 & 0 & 104 & -- & -- & 104 & 557 & 557 & BR \\
\hline CN6 & 2,627 & 0 & ND & ND & 82 & 82 & 568 & 568 & BR \\
\hline $\mathrm{CN} 8$ & 2,720 & 0 & 41 & -- & -- & 41 & 355 & 355 & BR \\
\hline CN9 & 2,621 & 0 & ND & ND & 46 & 46 & 513 & 513 & $\mathrm{BR}$ \\
\hline LL1 & 2,163 & 0 & 74 & -- & -- & 74 & 643 & 643 & PI \\
\hline LL2 & 2,138 & 0 & ND & ND & 237 & 237 & 554 & 554 & PI \\
\hline LL3 & 2,201 & 0 & 45 & 45 & 172 & 172 & 534 & 534 & PI \\
\hline LL4 & 2,188 & 0 & ND & ND & 51 & 51 & 656 & 656 & PI \\
\hline LL5 & 2,283 & 0 & ND & ND & 114 & 114 & 764 & 764 & PI \\
\hline LL6 & 2,037 & 0 & ND & ND & 80 & 80 & 495 & 495 & PI \\
\hline LL7 & 2,122 & 0 & 77 & -- & -- & 77 & 472 & 472 & PI \\
\hline LL8 & 2,098 & 0 & 182 & -- & -- & 182 & 467 & 467 & PI \\
\hline LL9 & 2,131 & 0 & 212 & -- & -- & 212 & 566 & 566 & PI \\
\hline LL10 & 1,926 & 0 & 55 & -- & -- & 55 & 324 & 324 & PI \\
\hline LL11 & 1,985 & 0 & 107 & -- & -- & 107 & 334 & 334 & PI \\
\hline LL12 & 1,989 & 0 & 43 & -- & -- & 43 & 269 & 269 & PI \\
\hline LL13 & 2,186 & 0 & 71 & 71 & 144 & 144 & 532 & 532 & PI \\
\hline LL14 & 2,192 & 0 & 155 & 155 & 259 & 259 & 375 & 375 & PI \\
\hline LL15 & 2,212 & 0 & 0 & -- & 260 & 260 & 701 & 701 & PI \\
\hline LL16 & 2,191 & 0 & 73 & -- & -- & 73 & 482 & 482 & PI \\
\hline LL17 & 2,360 & 0 & 80 & 80 & 241 & 241 & 717 & 717 & PI \\
\hline LL18 & 2,292 & 0 & 23 & 23 & 125 & 125 & 558 & 558 & PI \\
\hline LL19 & 2,416 & 0 & 138 & 138 & 249 & 249 & 572 & 572 & PI \\
\hline
\end{tabular}


Table 4. Stratigraphic contacts resulting from minimum-layer time-domain electromagnetic models of sounding sites, Elkhorn-Loup Model study area, 2010.-Continued

[Elevation, land-surface elevation above National Geodetic Vertical Datum of 1929 (NGVD 29); all depths given in feet below land surface; $\mathrm{T}_{\mathrm{QT}}$, top of Quaternary; $\mathrm{B}_{\mathrm{QT}}$, depth to bottom of Quaternary; $\mathrm{T}_{\mathrm{PP}}$, depth to top of Plio-Pleistocene gravel; $\mathrm{B}_{\mathrm{PP}}$, depth to bottom of Plio-Pleistocene gravel, italicized where top of unit is not distinguishable with overlying Quaternary units; $\mathrm{T}_{\mathrm{OG}}$, depth of top of Ogallala; $\mathrm{B}_{\mathrm{OG}}$, depth of bottom of Ogallala; $\mathrm{T}_{\mathrm{ACU}}$, depth to top of aquifer confining unit; $\mathrm{ACU}$, aquifer confining unit; $\mathrm{ND}$, depth of contact not determined; BR, Brule; --, contact not present; PI, Pierre Shale; NI, Niobrara Formation; CA, Carlile Shale]

\begin{tabular}{|c|c|c|c|c|c|c|c|c|c|}
\hline $\begin{array}{c}\text { Site } \\
\text { identifier }\end{array}$ & Elevation & $T_{0 T}$ & $\mathbf{B}_{0 T}$ & $\mathbf{T}_{\mathrm{PP}}$ & $\mathbf{B}_{\mathrm{pP}}$ & $T_{0 G}$ & $B_{0 G}$ & $\mathbf{T}_{\mathrm{ACU}}$ & ACU \\
\hline LL20 & 2,440 & 0 & 67 & 67 & 246 & 246 & 538 & 538 & PI \\
\hline LL21 & 2,319 & 0 & 98 & -- & -- & 98 & 589 & 589 & PI \\
\hline LL22 & 2,333 & 0 & 167 & -- & -- & 167 & 743 & 743 & PI \\
\hline LL23 & 2,467 & 0 & 317 & -- & -- & 317 & 679 & 679 & PI \\
\hline LL24 & 2,413 & 0 & 222 & -- & -- & 222 & 606 & 606 & PI \\
\hline LL25 & 2,295 & 0 & 124 & -- & -- & 124 & 453 & 453 & PI \\
\hline LL26 & 2,370 & 0 & ND & ND & 392 & 392 & 742 & 742 & PI \\
\hline LL27 & 2,284 & 0 & 55 & 55 & 96 & 96 & 896 & 896 & PI \\
\hline SH1 & 2,239 & 0 & ND & ND & 327 & 327 & 604 & 604 & PI \\
\hline $\mathrm{SH} 2$ & 2,326 & 0 & 92 & -- & -- & 92 & 520 & 520 & PI \\
\hline SH3 & 2,356 & 0 & 260 & -- & -- & 260 & 580 & 580 & PI \\
\hline SH4 & 2,365 & 0 & 193 & -- & -- & 193 & 670 & 670 & PI \\
\hline SH5 & 2,353 & 0 & 215 & -- & -- & 215 & 590 & 590 & PI \\
\hline SH6 & 2,130 & 0 & 195 & -- & -- & 195 & 515 & 515 & PI \\
\hline SH7 & 3,039 & 0 & 64 & -- & -- & 64 & 630 & 630 & $\mathrm{BR}$ \\
\hline SH8 & 3,193 & 0 & ND & ND & 592 & 592 & 754 & 754 & BR \\
\hline TDEM8 & 2,000 & 0 & 216 & -- & -- & 216 & 635 & 635 & NI \\
\hline TDEM9 & 1,824 & 0 & ND & ND & 192 & 192 & 759 & 759 & NI \\
\hline TDEM11 & 2,035 & 0 & 130 & -- & -- & 130 & 622 & 622 & PI \\
\hline TDEM16 & 1,698 & 0 & 107 & -- & -- & 107 & 228 & 228 & NI \\
\hline TDEM20 & 1,950 & 0 & ND & ND & 299 & 299 & 414 & 414 & PI \\
\hline TDEM41 & 1,681 & 0 & ND & ND & 43 & 43 & 145 & 145 & NI \\
\hline TDEM42 & 1,821 & 0 & ND & ND & 284 & 284 & 387 & 387 & NI \\
\hline TDEM43 & 1,854 & 0 & 179 & -- & -- & 179 & 409 & 409 & NI \\
\hline TDEM44 & 1,943 & 0 & 119 & -- & -- & 119 & 345 & 345 & NI \\
\hline TDEM48 & 1,995 & 0 & 120 & -- & -- & 120 & 354 & 354 & PI \\
\hline TDEM49 & 2,001 & 0 & 100 & -- & -- & 100 & 413 & 413 & PI \\
\hline TDEM68 & 1,882 & 0 & 97 & -- & -- & 97 & 444 & 444 & NI \\
\hline TDEM69 & 1,933 & 0 & 73 & -- & -- & 73 & 366 & 366 & PI \\
\hline TDEM70 & 1,762 & 0 & ND & ND & 122 & 122 & 307 & 307 & PI \\
\hline TDEM71 & 2,108 & 0 & ND & ND & 245 & 245 & 580 & 580 & PI \\
\hline TDEM79 & 1,651 & 0 & 278 & -- & -- & -- & -- & 278 & $\mathrm{CA}$ \\
\hline TDEM84 & 1,847 & 0 & 56 & 56 & 124 & 124 & 325 & 325 & $\mathrm{BR}$ \\
\hline TDEM86 & 1,723 & 0 & ND & ND & 54 & 54 & 310 & 310 & PI \\
\hline TDEM89 & 1,560 & 0 & ND & ND & 158 & 158 & -- & 158 & NI \\
\hline TDEM90 & 1,704 & 0 & 130 & -- & -- & -- & -- & 130 & NI \\
\hline TDEM91 & 1,880 & 0 & 225 & -- & -- & -- & -- & 225 & PI \\
\hline TDEM99 & 2,014 & 0 & 83 & -- & -- & 83 & 504 & 504 & PI \\
\hline TDEM140 & 2,099 & 0 & 43 & -- & -- & 43 & 403 & 403 & PI \\
\hline TDEM156 & 2,126 & 0 & 183 & 183 & 344 & 344 & 536 & 536 & PI \\
\hline TDEM158 & 1,747 & 0 & 16 & -- & -- & 16 & 339 & 339 & PI \\
\hline
\end{tabular}


Table 4. Stratigraphic contacts resulting from minimum-layer time-domain electromagnetic models of sounding sites, Elkhorn-Loup Model study area, 2010.-Continued

[Elevation, land-surface elevation above National Geodetic Vertical Datum of 1929 (NGVD 29); all depths given in feet below land surface; $\mathrm{T}_{\mathrm{QT}}$, top of Quaternary; $\mathrm{B}_{\mathrm{QT}}$, depth to bottom of Quaternary; $\mathrm{T}_{\mathrm{PP}}$, depth to top of Plio-Pleistocene gravel; $\mathrm{B}_{\mathrm{PP}}$, depth to bottom of Plio-Pleistocene gravel, italicized where top of unit is not distinguishable with overlying Quaternary units; $\mathrm{T}_{\mathrm{OG}}$, depth of top of Ogallala; $\mathrm{B}_{\mathrm{OG}}$, depth of bottom of Ogallala; $\mathrm{T}_{\mathrm{ACU}}$, depth to top of aquifer confining unit; $\mathrm{ACU}$, aquifer confining unit; ND, depth of contact not determined; BR, Brule; --, contact not present; PI, Pierre Shale; NI, Niobrara Formation; CA, Carlile Shale]

\begin{tabular}{|c|c|c|c|c|c|c|c|c|c|}
\hline $\begin{array}{c}\text { Site } \\
\text { identifier }\end{array}$ & Elevation & $\mathrm{T}_{\mathrm{aT}}$ & $\mathbf{B}_{\text {oT }}$ & $\mathbf{T}_{\mathrm{PP}}$ & $\mathbf{B}_{\mathrm{PP}}$ & $\mathbf{T}_{\mathrm{OG}}$ & $B_{0 G}$ & $\mathbf{T}_{\mathrm{ACU}}$ & ACU \\
\hline TDEM177 & 1,909 & 0 & 133 & -- & -- & 133 & 248 & 248 & PI \\
\hline TDEM178 & 1,933 & 0 & 46 & -- & -- & 46 & 380 & 380 & PI \\
\hline TDEM209 & 1,873 & 0 & 188 & -- & -- & 188 & 414 & 414 & PI \\
\hline TDEM210 & 1,709 & 0 & 67 & -- & -- & 67 & 284 & 284 & PI \\
\hline TDEM211 & 1,723 & 0 & 138 & -- & -- & 138 & 231 & 231 & PI \\
\hline TDEM212 & 2,130 & 0 & ND & ND & 69 & 69 & 432 & 432 & PI \\
\hline TDEM218 & 2,045 & 0 & 66 & -- & -- & 66 & 392 & 392 & PI \\
\hline TDEM223 & 3,728 & 0 & 233 & -- & -- & 233 & 1,168 & 1,168 & $\mathrm{BR}$ \\
\hline TDEM224 & 3,659 & 0 & 168 & -- & -- & 168 & 1,162 & 1,162 & $\mathrm{BR}$ \\
\hline TDEM228 & 3,678 & 0 & 171 & -- & -- & 171 & 1,395 & 1,395 & BR \\
\hline TDEM232 & 3,436 & 0 & 163 & 163 & 293 & 293 & 1,173 & 1,173 & BR \\
\hline UE1 & 2,071 & 0 & 38 & -- & -- & 38 & 462 & 462 & BR \\
\hline UE2 & 2,131 & 0 & ND & ND & 71 & 71 & 383 & 383 & PI \\
\hline UE3 & 2,379 & 0 & 135 & -- & -- & 135 & 574 & 574 & PI \\
\hline UE4 & 2,250 & 0 & $\mathrm{ND}$ & ND & 204 & 204 & 545 & 545 & PI \\
\hline UE5 & 2,209 & 0 & 36 & -- & -- & 36 & 472 & 472 & PI \\
\hline UE6 & 2,083 & 0 & 46 & -- & -- & 46 & 509 & 509 & BR \\
\hline UE7 & 2,118 & 0 & 61 & -- & -- & 61 & 447 & 447 & PI \\
\hline UE8 & 2,172 & 0 & 97 & -- & -- & 97 & 526 & 526 & BR \\
\hline UE9 & 2,075 & 0 & ND & ND & 212 & 212 & 424 & 424 & BR \\
\hline UE10 & 2,050 & 0 & -- & -- & 176 & 176 & 498 & 498 & PI \\
\hline UE11 & 2,160 & 0 & 100 & & -- & 100 & 325 & 325 & PI \\
\hline UL1 & 3,297 & 0 & ND & ND & 136 & 136 & 701 & 701 & BR \\
\hline UL2 & 3,379 & 0 & 78 & -- & -- & 78 & 833 & 833 & BR \\
\hline UL3 & 3,385 & 0 & 89 & -- & -- & 89 & 849 & 849 & BR \\
\hline UL4 & 3,416 & 0 & 44 & -- & -- & 44 & 690 & 690 & BR \\
\hline UL5 & 3,372 & 0 & 24 & -- & -- & 24 & 854 & 854 & BR \\
\hline UL6 & 3,103 & 0 & 217 & -- & -- & 217 & 936 & 936 & BR \\
\hline UL7 & 3,078 & 0 & ND & ND & 262 & 262 & 695 & 695 & BR \\
\hline UL8 & 3,081 & 0 & 242 & -- & -- & 242 & 737 & 737 & BR \\
\hline UL9 & 2,807 & 0 & 73 & -- & -- & 73 & 588 & 588 & BR \\
\hline UL10 & 2,874 & 0 & ND & ND & 111 & 111 & 812 & 812 & BR \\
\hline UL11 & 2,763 & 0 & ND & ND & 302 & 302 & 693 & 693 & BR \\
\hline UL12 & 2,937 & 0 & 276 & -- & -- & 276 & 735 & 735 & BR \\
\hline UL13 & 2,929 & 0 & 149 & -- & -- & 149 & 528 & 528 & BR \\
\hline UL14 & 2,966 & 0 & 131 & -- & -- & 131 & 714 & 714 & BR \\
\hline UL15 & 3,105 & 0 & 218 & -- & -- & 218 & 898 & 898 & BR \\
\hline UL16 & 2,994 & 0 & ND & ND & 255 & 255 & 753 & 753 & BR \\
\hline UL18 & 3,258 & 0 & 143 & -- & -- & 143 & 990 & 990 & BR \\
\hline UL19 & 3,039 & 0 & 160 & -- & -- & 160 & 839 & 839 & BR \\
\hline
\end{tabular}




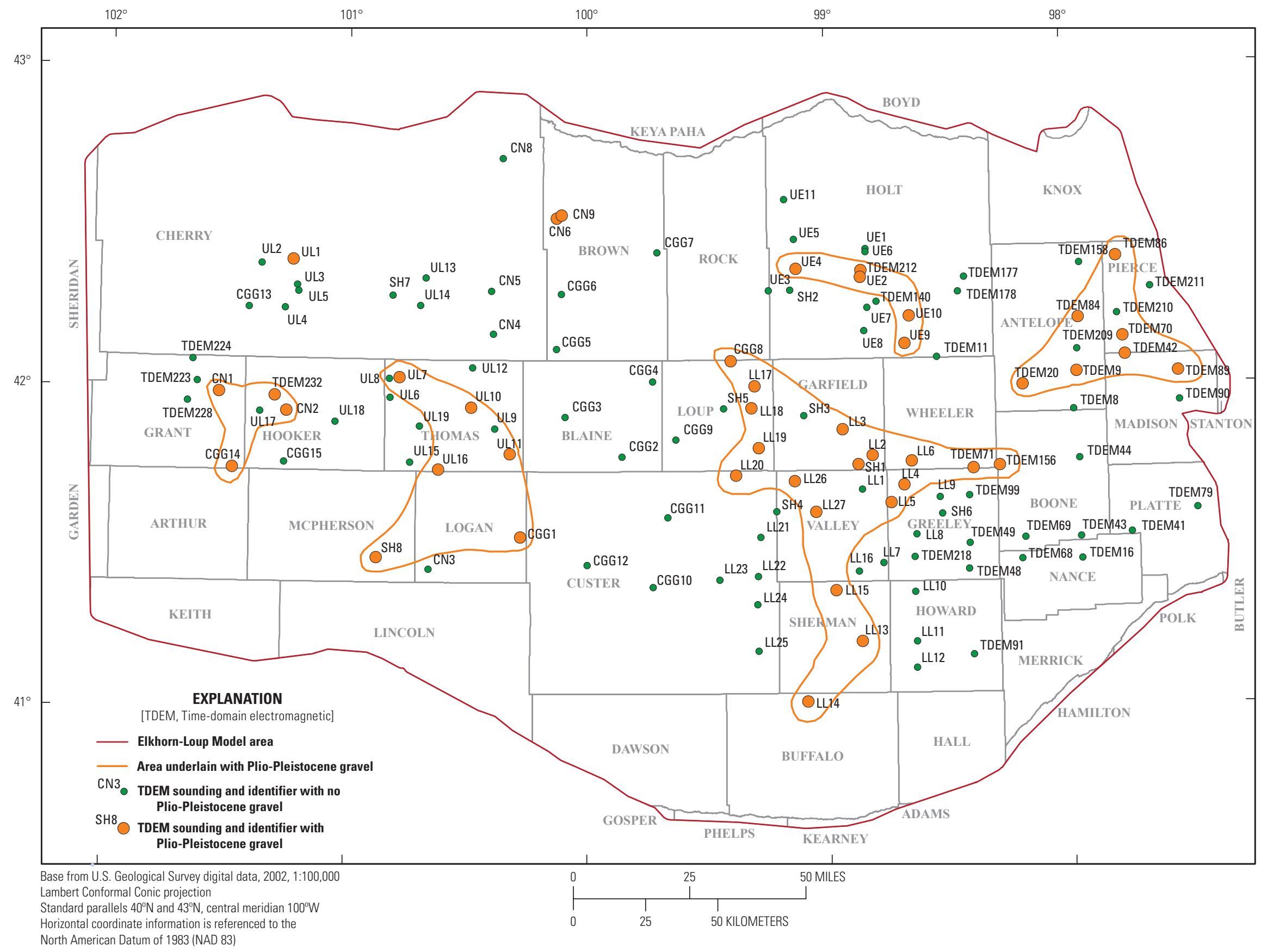

North American Datum of 1983 (NAD 83)

Figure 72. Five regions within the Elkhorn-Loup Model study area containing Plio-Pleistocene gravel deposits identified by modeled time-domain electromagnetic soundings. 
determined and compared to the corresponding values for nearby test holes. The PP layers may not have a depth-to-top layer defined because of inadequate contrast in resistivity or in thickness (table 4). In cases where the stratigraphy was not interpreted for CSD test holes, the stratigraphic picks used in this report were based on the described lithology and available geophysical logs (University of Nebraska-Lincoln Conservation and Survey Division, 2011). Differences between the modeled TDEM results and test-hole stratigraphy constituted the evaluation dataset for the QC sites. Results for the top of Ogallala $\left(\mathrm{T}_{\mathrm{OG}}\right)$ and top of $\mathrm{ACU}\left(\mathrm{T}_{\mathrm{ACU}}\right)$ are presented in table 5 .

Determining total aquifer thickness, or the depth of the ACU below land surface, was one of the primary objectives of this study. The TDEM technique was chosen to determine the depth to the ACU because those units underlying the aquifer have a much lower resistivity compared to the overlying units of Tertiary age. Differences between ACU elevations based on the modeled-TDEM resistivity and test-hole data ranged from 2 to $113 \mathrm{ft}$ ( 0.6 to $35 \mathrm{~m}$ ) (table 5). Some of these differences may be attributed to abrupt changes in subsurface geology. Of the 12 QC sites given in table 5, one-half are located in the Upper Loup NRD (fig. 1), where Hobza and others (2011) reported large changes in the elevation of the top of the ACU across short distances [less than 1,640 ft (500 m)].

Subdividing the hydrostratigraphy within the aquifer on the basis of resistivity-model results is a more challenging task because often the ranges in resistivity corresponding to individual stratigraphic units are very similar or overlap. Resistive targets, such as Plio-Pleistocene gravel sequences, are difficult to resolve because of the low-current densities

Table 5. Comparison of elevations of selected stratigraphic contacts based on minimum-layer time-domain electromagnetic model results and test-hole stratigraphy at Quality Control sites, Elkhorn-Loup Model study area, Nebraska.

[Elevation datum is National Geodetic Vertical Datum of 1929 (NGVD 29); $\mathrm{T}_{\mathrm{OG}}$, depth below land surface of top of Ogallala; $\mathrm{T}_{\mathrm{OG}}$ elevation, elevation of top of Ogallala; ABS difference, absolute value of the difference in elevation between the time-domain electromagnetic (TDEM)-based elevation and the test-hole elevation; $\mathrm{T}_{\mathrm{ACU}}$, depth below land surface of top of aquifer confining unit; $\mathrm{T}_{\mathrm{ACU}}$ elevation, elevation of top of aquifer confining unit; --, not applicable]

\begin{tabular}{|c|c|c|c|c|c|c|c|c|}
\hline $\begin{array}{c}\text { Site } \\
\text { identifier }\end{array}$ & $\begin{array}{l}\text { Elevation, } \\
\text { in feet }\end{array}$ & $\begin{array}{c}T_{0 G^{\prime}} \\
\text { in feet }\end{array}$ & $\begin{array}{c}\mathrm{T}_{\mathrm{OG}} \text { elevation, } \\
\text { in feet }\end{array}$ & $\begin{array}{c}T_{0 G} A B S \\
\text { difference, } \\
\text { in feet }\end{array}$ & $\begin{array}{c}T_{A C U^{\prime}} \\
\text { in feet }\end{array}$ & $\begin{array}{l}\mathrm{T}_{\mathrm{ACU}} \text { elevation, } \\
\text { in feet }\end{array}$ & $\begin{array}{c}T_{A C U} A B S \\
\text { difference, } \\
\text { in feet }\end{array}$ & $\begin{array}{c}\text { Data } \\
\text { source }^{1}\end{array}$ \\
\hline CGG2 & 2,521 & 166 & 2,355 & -- & 474 & 2,047 & -- & 1 \\
\hline 28-SH-85 & 2,520 & 154 & 2,365 & 11 & 532 & 1,988 & 60 & 3 \\
\hline $\mathrm{CN} 1$ & 3,587 & 166 & 3,421 & -- & 1,145 & 2,442 & -- & 1 \\
\hline 1-UL9 & 3,600 & 147 & 3,453 & 32 & 1,100 & 2,500 & 58 & 2 \\
\hline $\mathrm{CN} 2$ & 3,399 & 312 & 3,087 & -- & 1,042 & 2,357 & -- & 1 \\
\hline 2-UL9 & 3,390 & 290 & 3,100 & 13 & 920 & 2,470 & 113 & 2 \\
\hline CN4 & 2,760 & 68 & 2,693 & -- & 553 & 2,207 & -- & 1 \\
\hline 3-UL9 & 2,749 & 10 & 2,739 & 47 & 600 & 2,149 & 58 & 2 \\
\hline LL1 & 2,163 & 74 & 2,090 & -- & 643 & 1,520 & -- & 1 \\
\hline $1-B-83$ & 2,153 & 35 & 2,118 & 28 & 635 & 1,518 & 2 & 2 \\
\hline LL17 & 2,360 & 241 & 2,119 & -- & 717 & 1,643 & -- & 1 \\
\hline 57-HР-79 & 2,360 & 200 & 2,160 & 40 & 690 & 1,670 & 27 & 2 \\
\hline LL23 & 2,467 & 317 & 2,150 & -- & 679 & 1,788 & -- & 1 \\
\hline $3-\mathrm{LL}-10^{2}$ & 2,461 & 245 & 2,216 & 66 & 695 & 1,766 & 22 & 2 \\
\hline SH4 & 2,365 & 193 & 2,173 & -- & 670 & 1,696 & -- & 1 \\
\hline $15-A-59$ & 2,352 & 127 & 2,225 & 53 & 722 & 1,631 & 65 & 2 \\
\hline SH5 & 2,353 & 215 & 2,139 & -- & 590 & 1,763 & -- & 1 \\
\hline 56-НР-79 & 2,379 & 200 & 2,179 & 40 & 610 & 1,769 & 6 & 2 \\
\hline SH6 & 2,130 & 195 & 1,935 & -- & 515 & 1,615 & -- & 1 \\
\hline $48-A-57$ & 2,151 & 305 & 1,846 & 89 & 561 & 1,590 & 25 & 3 \\
\hline SH8 & 3,193 & 592 & 2,601 & -- & 754 & 2,439 & -- & 1 \\
\hline 6-S-82 & 3,172 & 320 & 2,852 & 251 & 735 & 2,437 & 2 & 3 \\
\hline UL19 & 3,039 & 160 & 2,879 & -- & 839 & 2,200 & -- & 1 \\
\hline 1-UL-10 & 3,060 & 275 & 2,785 & 94 & 800 & 2,265 & 60 & 2 \\
\hline
\end{tabular}

${ }^{1}$ Source of hydrostratigraphic pick, where 1 is TDEM-based model, 2 is interpreted by the authors, and 3 is interpreted by University of Nebraska Conservation and Survey Division. 
induced within resistive layers as compared to conductive layers. As such, differentiating Plio-Pleistocene deposits from the base of the Quaternary deposits or top of the Ogallala may not be possible using the data collected for this study if there is insufficient thickness and contrast in resistivity of the deposits. The differences in elevation of the top of the Ogallala, estimated on the basis of the TDEM resistivity models, and the test-hole data ranged from 11 to $251 \mathrm{ft}$ (3.4 to $77 \mathrm{~m}$ ) (table 5), with two-thirds of model results being within $60 \mathrm{ft}(20 \mathrm{~m})$ of the test-hole contact elevation. The largest difference was from site SH8 (test hole 6-S-82), where the minimum-layer and smooth-layer models indicated very uniform resistivity across the Quaternary-Ogallala contact, and no abrupt change in resistivity occurred until the depth of the ACU was reached. In such cases, the modeled resistivity values of the Ogallala and overlying units are very similar and potentially overlap. Thus, any hydrostratigraphic interpretation of the top of the Ogallala based solely on modeled, TDEM-based resistivity data should be carefully considered.

\section{Summary}

The Elkhorn-Loup Model (ELM) was begun in 2006 to understand the effect of various groundwater-management scenarios on surface-water resources. During phase one of the ELM study, a lack of subsurface geological information was identified as a data gap. Test holes drilled to the base of the aquifer in the ELM study area are spaced up to 25 miles apart, especially in areas of the western Sand Hills. Given the variable character of the hydrostratigraphic units that compose the High Plains aquifer system, substantial variation in aquifer thickness and characteristics can exist between test holes. To improve the hydrogeologic understanding of the ELM study area, the U.S. Geological Survey, in cooperation with the Nebraska Department of Natural Resources, the ELM NRDs, and the University of Nebraska-Lincoln Conservation and Survey Division, described the subsurface lithology at six test holes and concurrently collected borehole geophysical data to identify the base of the High Plains aquifer system. Surface geophysical data also were collected using time-domain electromagnetic (TDEM) methods at and between selected testhole locations as a quick, non-invasive means of identifying the base of the High Plains aquifer system. The data collected for this study allow improved knowledge of the aquifer thickness and the topography of the base-of-aquifer surface, which are important for assessing water supply and understanding groundwater flow.

Site selection for test-hole drilling and surface geophysical data collection was guided by several factors, but primarily was intended to fill existing gaps in the test-hole database. Geophysical methods were selected on the basis of physical characteristics of the hydrostratigraphic units of the ELM study area and the anticipated depth to the base of aquifer. In 2010, six test holes were drilled to below the base of aquifer, and borehole geophysical data were logged. A total of 124 TDEM soundings (of which 123 were used) were collected within the ELM study area between 2008 and 2011. TDEM data were inverted for two end-member model classes - a minimum-layer inverse model and 20-layer smooth, or Occam-style, inverse model - both as one-dimensional models.

Results from test-hole drilling and geophysical logging indicated differences between elevations of the drilled base of aquifer and the previously estimated base of aquifer that ranged from -131 to $34 \mathrm{ft} \mathrm{(-40} \mathrm{to} 10 \mathrm{~m}$ ). This range in differences is less than those previously reported for the western part of the ELM study area, where deeper paleochannels were eroded into the Brule.

In total, more than 435 test holes were examined and compared with the modeled-TDEM soundings. Even where present, individual stratigraphic units could not always be identified in modeled-TDEM sounding results if sufficient resistivity contrast was not evident; however, in general, the base of aquifer (top of the aquifer confining unit) is one of the best-resolved results from the resistivity models. Estimates of the base-of-aquifer elevation are in good accordance with those from existing test-hole data.

The TDEM data generally support four- to nine-layer models for resistivity stratigraphy. The modeled resistivity results reflect the eastward thinning of Miocene-age and older stratigraphic units, and generally allowed confident identification of the accompanying change in the stratigraphic unit forming the aquifer confining unit (ACU). Models from the western ELM study area (Cherry, Grant, Hooker, Thomas, Arthur, McPherson, and Logan Counties) exhibit decreasing resistivity, with increasing depth below about 300-400 ft (91-120 m) below land surface. In many cases, these models indicated a thick Ogallala sequence atop the low-resistivity Brule or Pierre Shale. The modeledTDEM soundings also provided information regarding the distribution of Plio-Pleistocene (PP) gravel deposits within the study area. These deposits are typically more resistive (about $100 \mathrm{ohm}-\mathrm{m}$ ) than the overlying Quaternary sediments or the underlying Ogallala. The average thickness of the PP deposits in the study area is $100 \mathrm{ft}(30 \mathrm{~m})$, although in many cases the Quaternary-PP contact cannot be reliably distinguished using only TDEM soundings because of insufficient thickness or resistivity contrast.

A subset of all the TDEM sites were collected near existing or planned test holes. Determining total aquifer thickness, or the depth of the ACU, was one of the primary objectives of this study. Differences between ACU elevations based on modeled-TDEM and test-hole data ranged from 2 to $113 \mathrm{ft}$ (0.6 to $34 \mathrm{~m})$. Generally, larger differences were associated with deeper ACUs and occurred in the western study area. Subdividing the hydrostratigraphy within the aquifer on the basis of TDEM-based resistivity-model results is a more challenging task because often the ranges in resistivity corresponding to individual stratigraphic units are very similar or overlap. The differences in elevation of the top of 
the Ogallala estimated on the basis of the modeled-TDEM resistivity and the test-hole data ranged from 11 to $251 \mathrm{ft}$ (3.4 to $77 \mathrm{~m}$ ), with two-thirds of model results being within $60 \mathrm{ft}(18 \mathrm{~m})$ of the test-hole contact elevation. As such, any hydrostratigraphic interpretation of the top of the Ogallala based solely on modeled, TDEM-based resistivity data should be carefully considered.

\section{References Cited}

Aarhus Hydrogeophysics Group, 2008, Manual for the Inversion Program em1dinv program version 5.20: Aarhus, Denmark, Hydrogeophysics Group, University of Aarhus, accessed on August 1, 2012, at http://www.hgg.geo.au.dk/ HGGsoftware/em1dinv/em1dinv_manual.pdf.

Anderson, J.A., Morin, R.H., Cannia, J.C., and Williams, J.H., 2009, Geophysical log analysis of selected test holes and wells in the High Plains aquifer, Central Platte River basin, Nebraska: U.S. Geological Survey Scientific Investigations Report 2009-5033, 16 p. (Also available online at $h t t p: / /$ pubs.usgs.gov/sir/2009/5033/).

Auken, E., and Nebel, K., 2001, Getting started with SiTEM and SEMDI: Aarhus, Denmark, Hydrogeophysics Group, University of Aarhus, Department. of Earth Sciences, 21 p.

Bentall, Ray, 1989, Streams, in Bleed, A.S., and Flowerday, C.A., eds., An atlas of the Sand Hills: Lincoln, Nebr., University of Nebraska, Conservation and Survey Division, Resource Atlas, no. 5a, p. 93-114.

Biella, G., Lozej, A., and Tabacco, I., 1983, Experimental study of some hydrogeophysical properties of unconsolidated porous media: Ground Water, v. 21, no. 6, p. 741-751.

Bleed, A.S., 1989, Groundwater, in Bleed, A.S., and Flowerday, C.A., eds., An atlas of the Sand Hills: Lincoln, Nebr., University of Nebraska, Conservation and Survey Division, Resource Atlas, no. 5a, p. 67-92.

Burchett, R.R., Reed, E.C., and Dreeszen, V.H., 1975, Bedrock geologic map showing thickness of overlying Quaternary deposits, Fremont Quadrangle and part of Omaha Quadrangle, Nebraska: U.S. Geological Survey Miscellaneous Investigations Series Map I-905, scale 1:250,000.

Cast, L.D., 2000, Custer County test-hole logs: Lincoln, Nebr., University of Nebraska-Lincoln, Institute of Agriculture and Natural Resources, Conservation and Survey Division, Nebraska Water Survey Test-Hole Report No. 21, 201 p.

Century Geophysical Corp., 2011, 9144 Series E Logging Tool: Tulsa, Okla., 2 p., accessed July 16, 2012, at $h t t p: / / w w w . c e n t u r y$-geo.info/dnn/EquipmentSales/ LoggingTools/9044UsersGuide.aspx.
Chen, Xi, Chen, Xunhong, Rowe, Clinton, Hu, Qi, and Andersen, Mark, 2003, Geological and climatic controls on streamflows in the Nebraska Sand Hills: Journal of the American Water Resources Association, v. 39, p. 217-228.

Christiansen, A.V., and Auken, E., 2010, A global measure for depth of investigation in EM and DC modeling, in ASEG2010 International Geophysical Conference, 21st, 2010, Extended Abstracts: Sydney, Australian Society of Exploration Geophysicists, 4 p., doi:10.1071/ ASEG2010ab266. (Also available online at $h t t p: / / w w w$. publish.csiro.au/paper/ASEG2010ab266.htm).

Christiansen, A.V., Auken, E., and Viezzoli, A., 2011, Quantification of modeling errors in airborne TDEM caused by inaccurate system description: Geophysics, v. 76, doi:10.1190/1.3511354. (Also available online at $h t t p: / /$ geophysics.geoscienceworld.org/content/76/1/F43.full. $p d f+h t m l)$.

Condon, S.M., 2005, Geologic studies of the Platte River, south-central Nebraska and adjacent areas-geologic maps, subsurface study, and geologic history: U.S. Geological Survey Professional Paper 1706, 63 p. (Also available at $h t t p: / /$ pubs.usgs.gov/pp/pp1706/).

Condra, G.E., and Reed, E.C., 1943, The geological section of Nebraska: Lincoln, Nebr., University of Nebraska-Lincoln, Conservation and Survey Division, Nebraska Geological Survey Bulletin, v. 14, p. 82.

Constable, S.C., Parker, R.L., and Constable, C.G., 1987, Occam's inversion-A practical algorithm for generating smooth models from electromagnetic sounding data: Geophysics, v. 52, no. 3, p. 289-300.

Danielsen, J.E., Auken, E., Jørgensen, F., Søndergaard, V., and Sørensen, K. I., 2003, The application of the transient electromagnetic method in hydrogeophysical surveys: Journal of Applied Geophysics, v. 53, no. 4, p. 181-198.

Darton, N.H., 1903, Preliminary report on the geology and water resources of Nebraska west of the one hundred and third meridian: U.S. Geological Survey Professional Paper 17, 69 p., 43 pls. (Also available online at http://pubs. usgs.gov/pp/0017/report.pdf).

Diffendal, R.F., Jr., 1991, Geologic map showing configuration of the bedrock surface, North Platte $1^{\circ} \times 2^{\circ}$ quadrangle, Nebraska: U.S. Geological Survey Miscellaneous Investigation Series Map I-2277, scale 1:250,000.

Diffendal, R.F., Jr., Voorhies, M.R., Voorhies, E.J., LaGarry, H.E., Timperley, C.L., and Perkins, M.E., 2008, Geologic map of the O'Neill $1^{\circ} \times 2^{\circ}$ quadrangle, Nebraska, with configurations of surfaces of formations: Lincoln, Nebr., University of Nebraska-Lincoln, Conservation and Survey Division, Geologic Map GMC-34, scale 1:250,000. 
Dugan, J.T., and Zelt, R.B., 2000, Simulation and analysis of soil-water conditions in the Great Plains and adjacent areas, central United States, 1951-80: U.S. Geological Survey Water-Supply Paper 2427, 81 p.

Fitterman, D.V., and Labson, V.F., 2005, Electromagnetic induction methods for environmental problems, in Butler, D.K., ed., Near surface geophysics: Tulsa, Okla., Society of Exploration Geophysicists, SEG Investigations in Geophysics Series, no. 13, p. 301-355.

Geological Institute, 2002a, Vejledning i kalibrering af TEM måleudstyr (in Danish): Aarhus, Denmark, Aarhus University, $12 \mathrm{p}$.

Geological Institute, 2002b, Test og sammenligning af Transient Elektromagnetiske instrumenter i Danmark (in Danish): Aarhus, Denmark, Aarhus University, 118 p.

Goeke, J.W., 2000, McPherson County test-hole logs: Lincoln, Nebr., University of Nebraska-Lincoln, Institute of Agriculture and Natural Resources, Conservation and Survey Division, Nebraska Water Survey Test-Hole Report No. 60, $50 \mathrm{p}$.

Gutentag, E.D., Heimes, F.J., Krothe, N.C., Luckey, R.R., and Weeks, J.B., 1984, Geohydrology of the High Plains aquifer in parts of Colorado, Nebraska, New Mexico, Oklahoma, South Dakota, Texas, and Wyoming: U.S. Geological Survey Professional Paper 1400-B, 63 p.

Hallenburg, J.K., 1998, Non-hydrocarbon methods of geophysical formation evaluation: Boca Raton, Fla., Lewis Publishers, $265 \mathrm{p}$.

Hearst, J.R., and Nelson, P.H., 1985, Well logging for physical properties: New York, McGraw-Hill, 571 p.

Hearst, J.R., Nelson, P.H., and Paillet, F.L., 2000, Well logging for physical properties ( $2 \mathrm{~d}$ ed.): New York, John Wiley, $483 \mathrm{p}$.

Helgesen, J.O., Leonard, R.B., and Wolf, R.J., 1993, Hydrology of the Great Plains aquifer system in Nebraska, Colorado, Kansas, and adjacent areas: U.S. Geological Survey Professional Paper 1414-E, 80 p.

Hobza, C. M., Asch, Theodore, Bedrosian, P. A., 2011, Hydrostratigraphic interpretation of test-hole and surface geophysical data, Upper Loup River basin, Nebraska, 2008 to 2010: U.S. Geological Survey Open-File Report 2011-1289, 60 p. (Also available at $h t t p: / / p u b s . u s g s . g o v / o f / 2010 / 1289 /$ ).

Keller, G.V., 1987, Rock and mineral properties, in Nabighian, M.N., ed., Electromagnetic methods in applied geophysics theory: Tulsa, Okla., Society of Exploration Geophysicists, v. 1, p. 13-51.

Keller, G.V., 1989, Electrical properties, in Carmichael, R.S., ed., Practical handbook of physical properties of rocks and minerals: Boca Raton, Fla., CRC Press, p. 359-427.
Keys, W.S., 1990, Borehole geophysics applied to groundwater investigations: U.S. Geological Survey Techniques of Water-Resources Investigations, book 2, chap. E2, p. 49-82, 109-113. (Also available at http://pubs.usgs.gov/twri/ twri2-e2/).

Kwader, T., 1985, Estimating aquifer permeability from formation resistivity factors: Ground Water, v. 23, no. 6, p 762-766.

McGuire, V.L., and Peterson, S.M., 2008, Base of principal aquifer for the Elkhorn-Loup model area, north-central Nebraska: U.S. Geological Survey Scientific Investigations Map 3042, 1 sheet. (Also available at http://pubs.usgs.gov/ $\mathrm{sim} / 3042)$.

McGuire, V.L., and Fischer, B.C., 1999, Water-level changes, 1980 to 1997, and saturated thickness, 1996-97, in the High Plains aquifer: U.S. Geological Survey Fact Sheet 124-99, 4 p.

Nabighian, M. N., and Macnae, J. C., 1991, Time-domain electromagnetic prospecting methods, in Nabighian, M. N., ed., Electromagnetic methods in applied geophysics: Tulsa, Okla., Society of Exploration Geophysicists, SEG Investigations in Geophysics, no. 3, Application, Parts A and B, p. $427-520$.

Nebraska Oil and Gas Conservation Commission, 2012, Well data including formation tops: Sidney, Nebr., accessed April 2, 2012, at http://www.nogcc.ne.gov/ NOGCCPublications.aspx/NebraskaWellData_Tops.zip.

Ostdiek, Amy, 2009, The integrated management planning process: Lincoln, Nebr., Nebraska Dept. of Natural Resources, Water Matters, no. 1, 4 p., accessed November 3, 2010, at http://www.dnr.state.ne.us/IWM/WaterMatters/ WaterMatters_No1.pdf.

Palacky, G.J., 1987, Resistivity characteristics of geologic targets, in Nabighian, M.N., ed., Electromagnetic methods in applied geophysics theory: Tulsa, Okla., Society of Exploration Geophysicists, v. 1, p. 53-129.

Peterson, S.M., Stanton, J.S., Saunders, A.T., and Bradley, J.R., 2008, Simulation of ground-water flow and effects of ground-water irrigation on base flow in the Elkhorn and Loup River Basins, Nebraska: U.S. Geological Survey Scientific Investigations Report 2008-5143, 65 p. (Also available at http://pubs.usgs.gov/sir/2008/5143/).

Souders, V.L., 2000, Geologic maps and cross sections showing configurations of bedrock surfaces, Broken Bow $1^{\circ} \times 2^{\circ}$ Quadrangle, east-central Nebraska: U.S. Geological Survey Geologic Investigations Series I-2725, scale 1:250,000.

Stanley, K.O., and Wayne, W.J., 1972, Epeirogenic and climatic controls of early Pleistocene fluvial sediment dispersal in Nebraska: Geological Society of America. Bulletin, v. 83 , p. 3,675-3,690. 
Stanton, G.P., Kress, W.H., Teeple, A.P., Greenslate, M.I., and Clark, A.K., 2007, Geophysical analysis of the Salmon Peak Formation near Amistad Reservoir dam, Val Verde County, Texas, and Coahuila, Mexico, March 2006, to aid in piezometer placement: U.S. Geological Survey Scientific Investigations Report 2007-5143, 70 p. (Also available at http://pubs.usgs.gov/sir/2007/5143/).

Stanton, J.S., Peterson, S.M., and Fienen, M.N., 2010, Simulation of groundwater flow and effects of groundwater irrigation on stream base flow in the Elkhorn and Loup River Basins, Nebraska, 1895-2055-Phase two: U.S. Geological Survey Scientific Investigations Report 2010-5149, 78 p. (Also available at http://pubs.usgs.gov/ $\operatorname{sir} / 2010 / 5149 /)$.

Strauch, K.R., and Linard, J.I., 2009, Streamflow simulations and percolation estimates using the Soil and Water Assessment Tool for selected basins in north-central Nebraska, 1940-2005: U.S. Geological Survey Scientific Investigations Report 2009-5075, 20 p. (Also available at $h t t p: / /$ pubs.usgs.gov/sir/2009/5075/).
Swinehart, J.B., and Diffendal, R.F., 1989, Geology, in Bleed, A.S., and Flowerday, C.A., eds., An atlas of the Sand Hills: Lincoln, Nebr., University of Nebraska, Conservation and Survey Division, Resource Atlas, no. 5a, p. 29-42.

Swinehart, J.B., Souders, V.L., DeGraw, H.M., and Diffendal, R.F., 1985, Cenozoic paleogeography of western Nebraska, in Flores, R.M., and Kaplan, S.S., eds., Cenozoic paleogeography of the west-central United States-Rocky Mountain Paleogeography Symposium, 3rd, Denver, 1985, Proceedings: Denver, Colo., Rocky Mountain Section, Society of Economic Paleontologists and Mineralogists, p. 209-229.

University of Nebraska-Lincoln Conservation and Survey Division, 2011, Test-hole database: Lincoln, Nebr., Conservation and Survey Division, digital data, accessed June 12, 2012, at http://snr.unl.edu/data/geologysoils/ NebraskaTestHole/NebraskaTestHoleIntro.asp.

Wigley, P.B., 2000, Logan County test-hole logs: Lincoln, Nebr., University of Nebraska-Lincoln, Conservation and Survey Division, Nebraska Water Survey Test-Hole Report No. $57,17 \mathrm{p}$. 



\section{Supplemental Data}




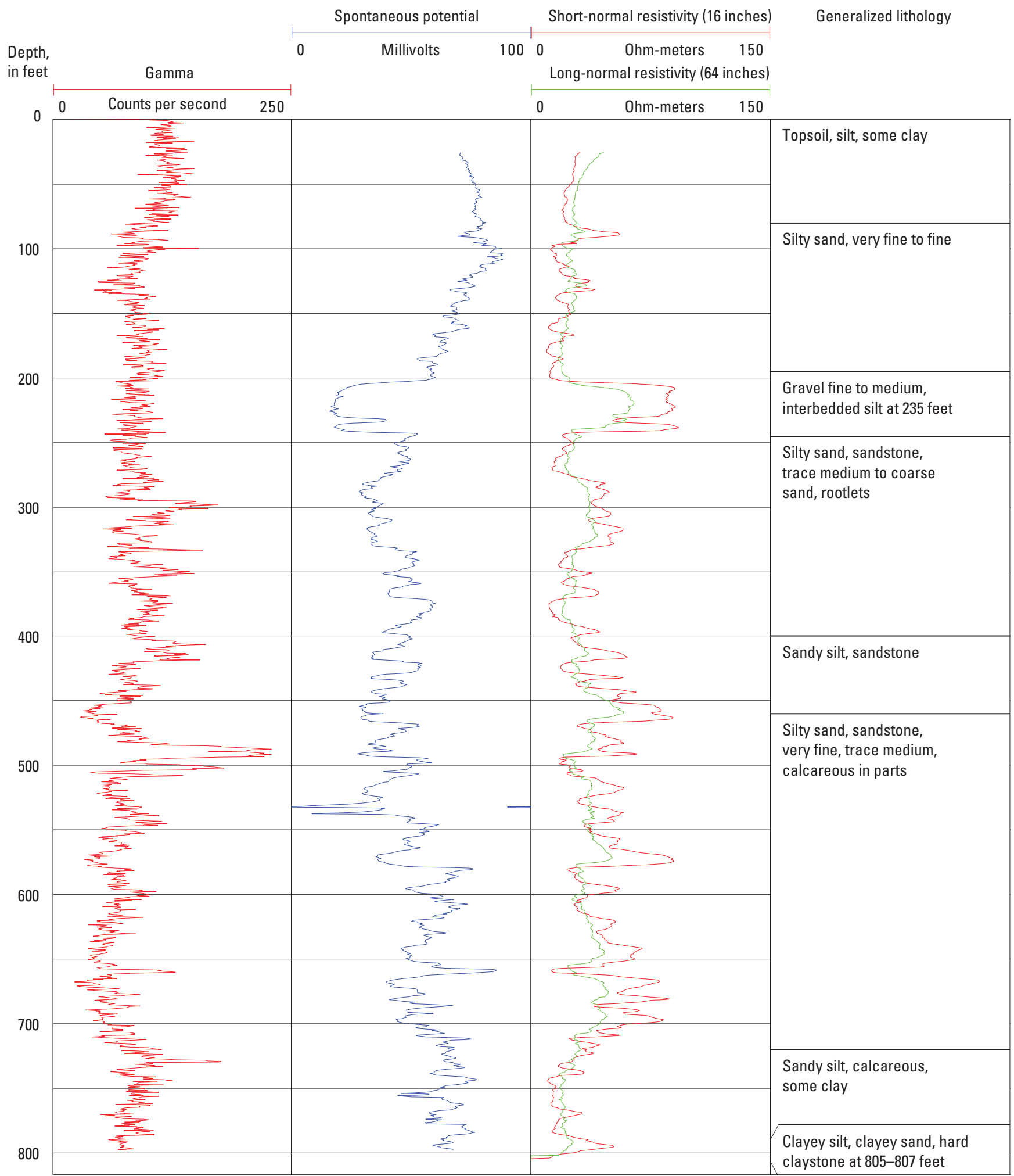

Figure 4. Composite of generalized lithologic description and geophysical logs for test hole 2-LL-10, Custer County, Nebraska. Short-normal resistivity, in ohm-meters; Iong-normal resistivity, in ohm-meters; natural gamma activity, in counts per second; spontanenous potential, in millivolts. 
Depth

\begin{tabular}{|ccccc} 
& Spontaneous potential & & \multicolumn{3}{c}{ Short-normal resistivity (16 inches) } \\
\hline-25 & Millivolts & 75 & 0 & Ohm-meters 100
\end{tabular}

Generalized lithology

in feet

\section{Gamma}

Long-normal resistivity (64 inches)

\begin{tabular}{lll|lrl|}
0 & 0 & Counts per second 200 & 0 & $0 \mathrm{hm}-\mathrm{m}$ & 100
\end{tabular}

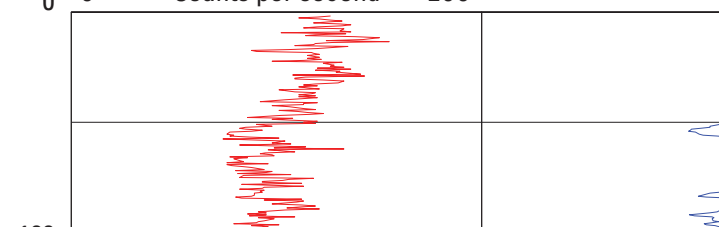

100

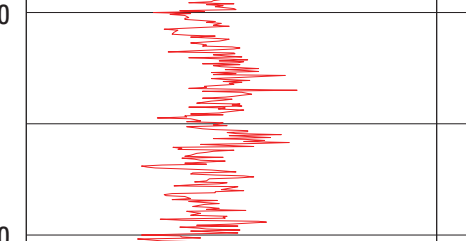

200

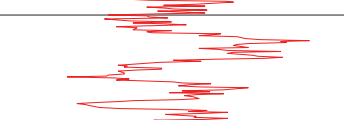

妾

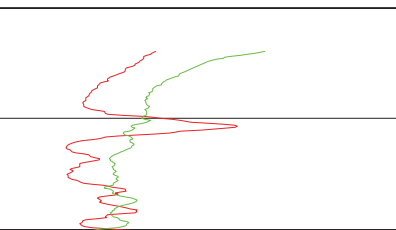
Clayey silt, sandy
in parts, calcareous in
parts

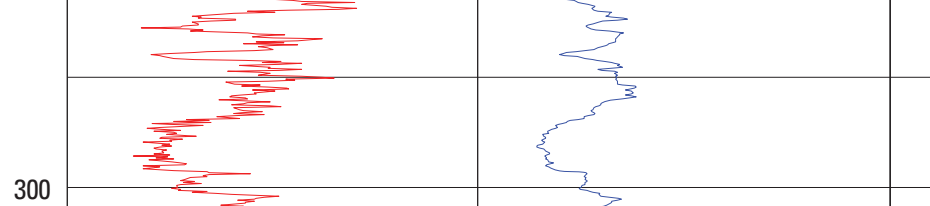

300
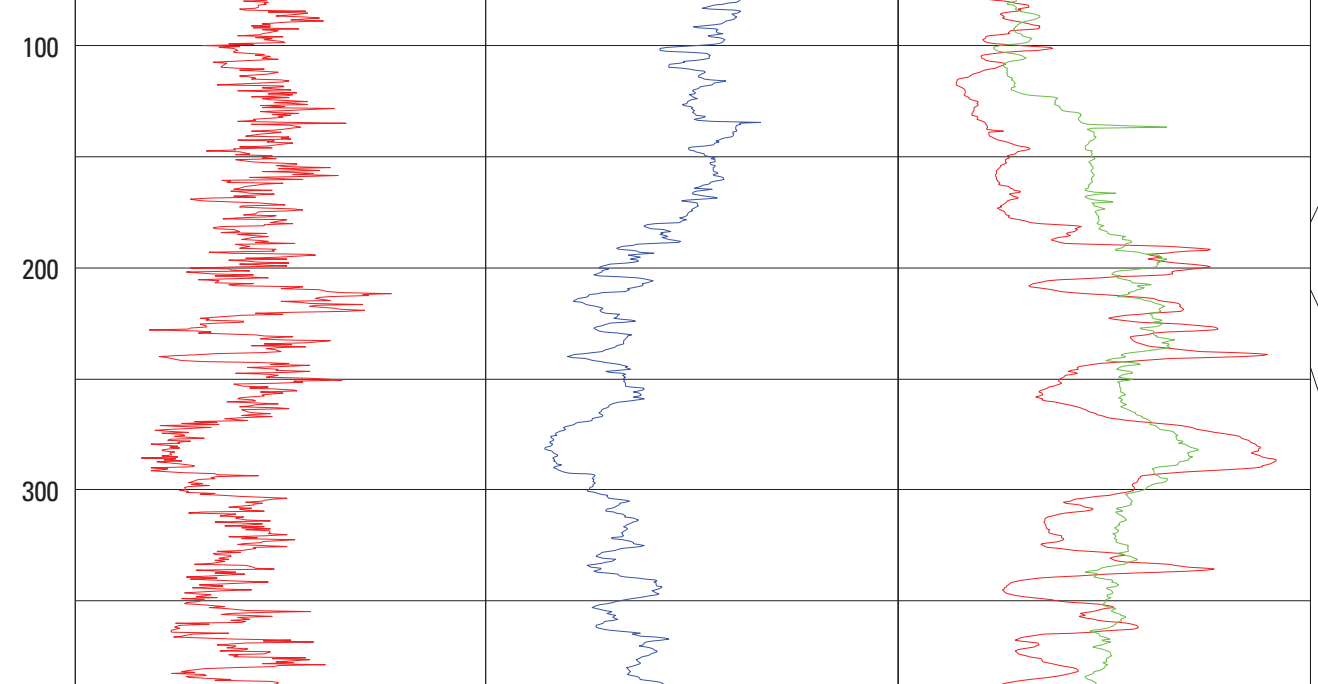

400

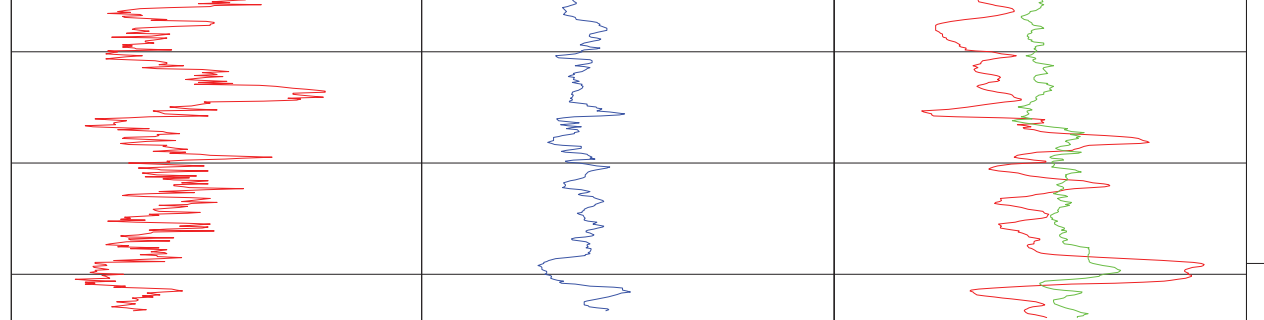

500

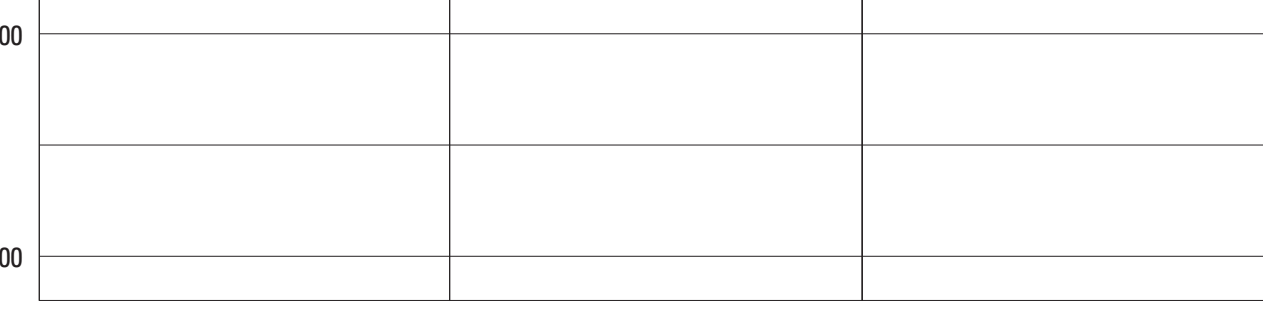

Sand, fine to medium, trace silt, sand fine at bottom

Silty sand, sandstone, calcareous in parts

Pierre Shale, yellowish to gray

Figure 5. Composite of generalized lithologic description and geophysical logs for test hole 3-LL-10, Custer County, Nebraska. Short-normal resistivity, in ohm-meters; long-normal resistivity, in ohm-meters; natural gamma activity, in counts per second; spontanenous potential, in millivolts. 


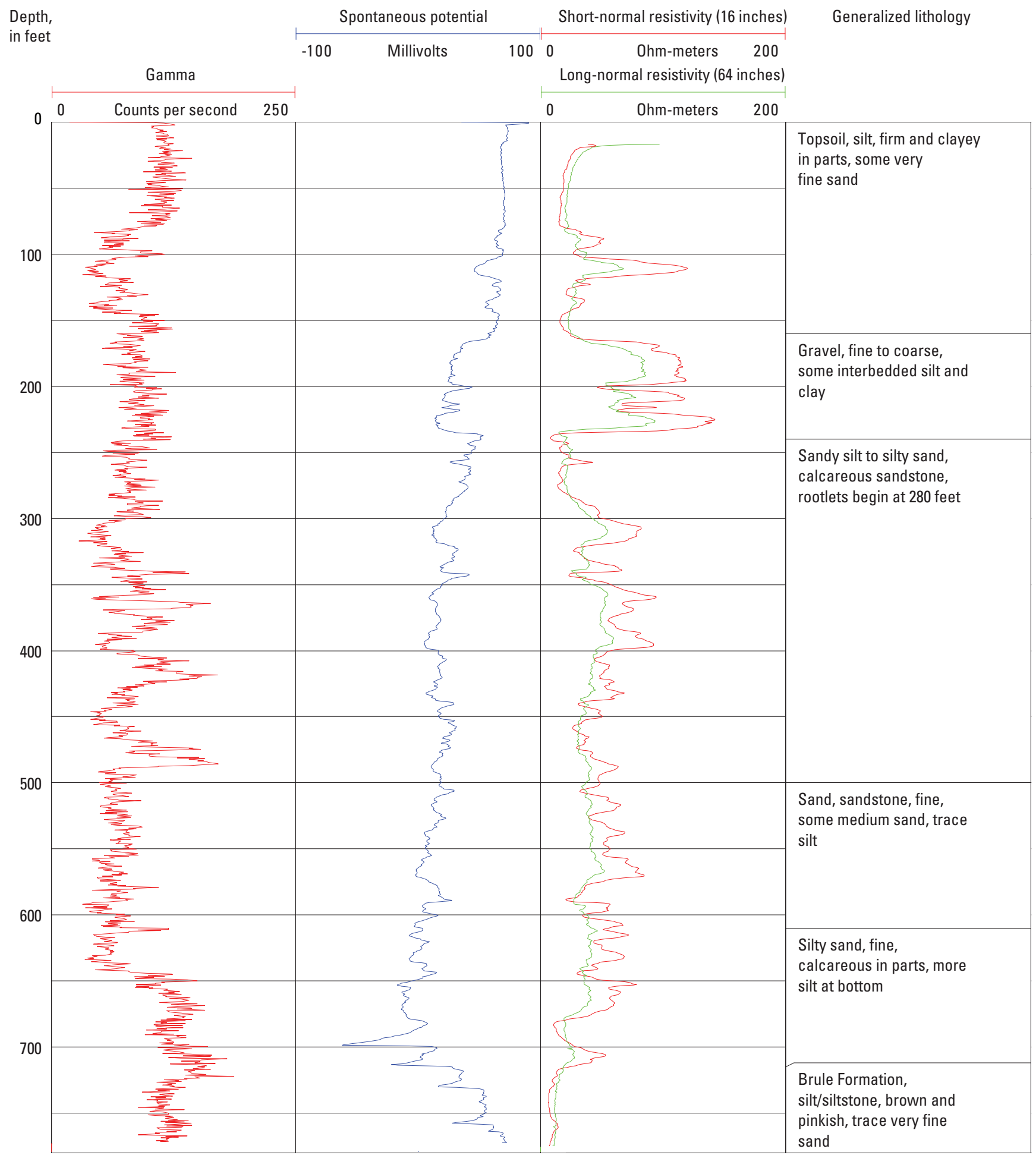

Figure 6. Composite of generalized lithologic description and geophysical logs for test hole 4-LL-10, Custer County, Nebraska. Short-normal resistivity, in ohm-meters; long-normal resistivity, in ohm-meters; natural gamma activity, in counts per second; spontanenous potential, in millivolts. 


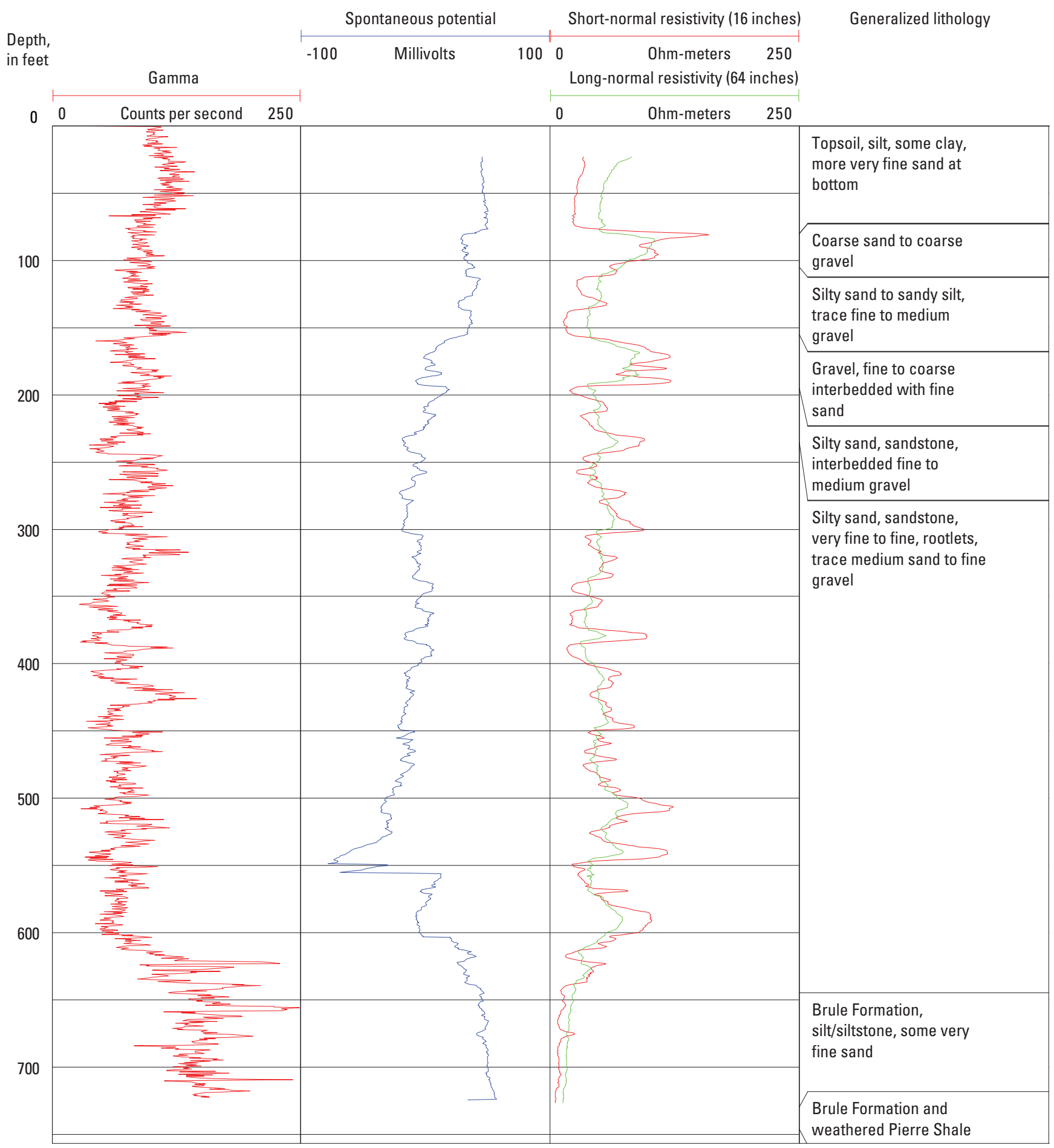

Figure 7. Composite of generalized lithologic description and geophysical logs for test hole 6-LL-10, Custer County, Nebraska. Short-normal resistivity, in ohm-meters; long-normal resistivity, in ohm-meters; natural gamma activity, in counts per second; spontanenous potential, in millivolts. 


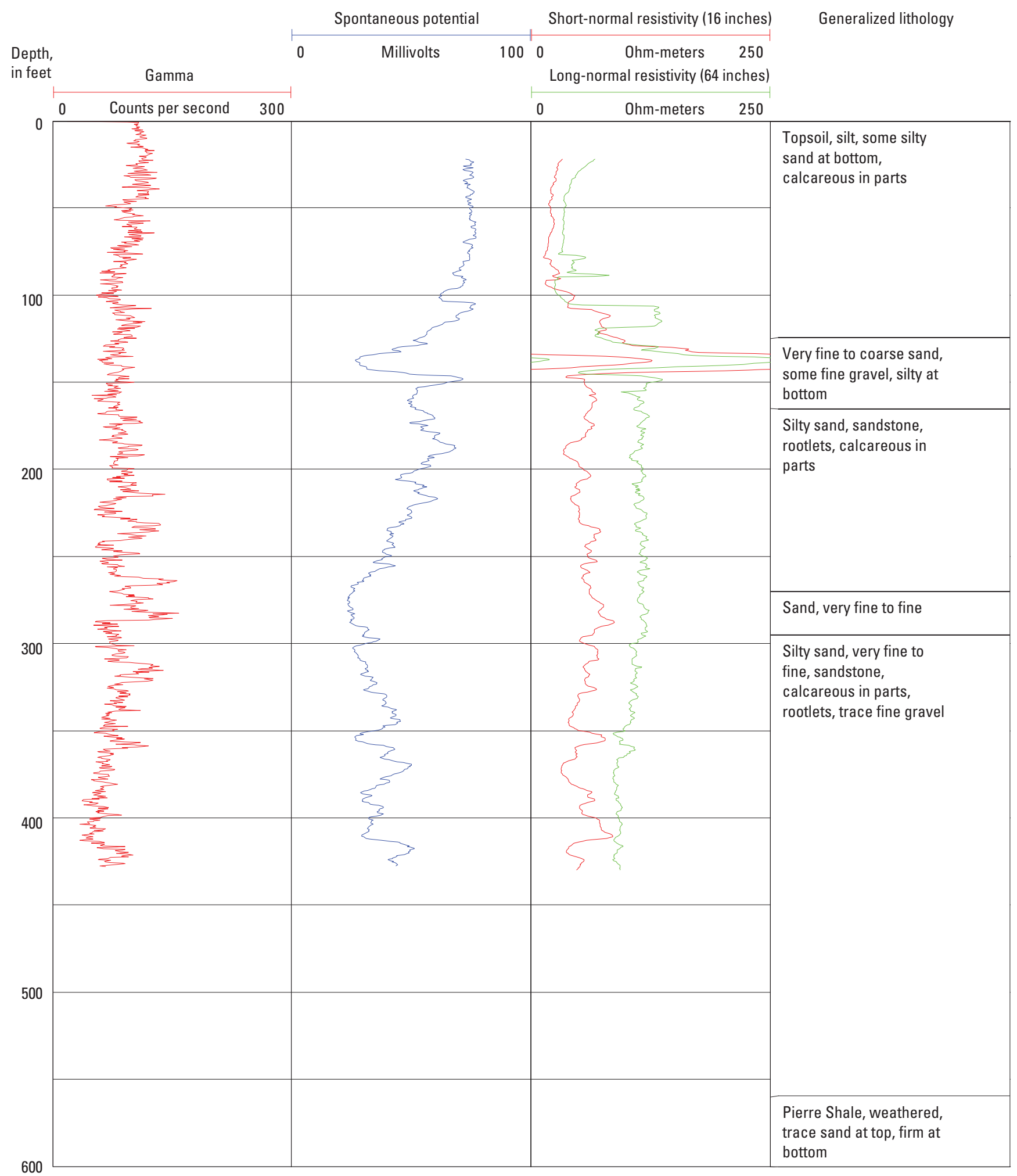

Figure 8. Composite of generalized lithologic description and geophysical logs for test hole 7-LL-10, Custer County, Nebraska. Short-normal resistivity, in ohm-meters; long-normal resistivity, in ohm-meters; natural gamma activity, in counts per second; spontanenous potential, in millivolts. 

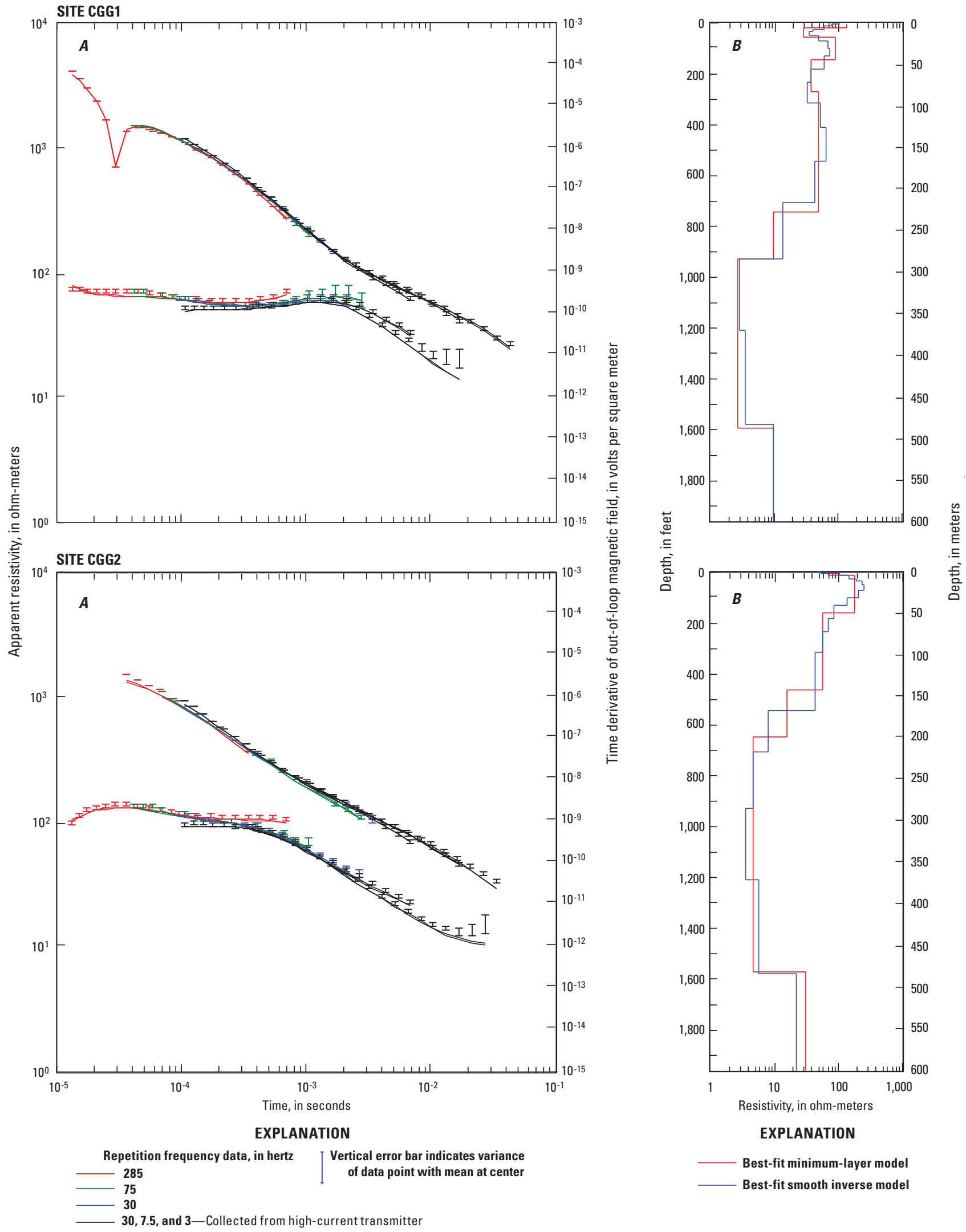

Figure 10. Relations between $A$, central-loop resistivity, out-of-loop vertical magnetic field (upper set of curves time-derivative, right axis), and time elapsed after primary current turnoff; and $B$, depth below land surface and subsurface resistivity modeled from time-domain electromagnetic sounding for sites CGG1 and CGG2. 

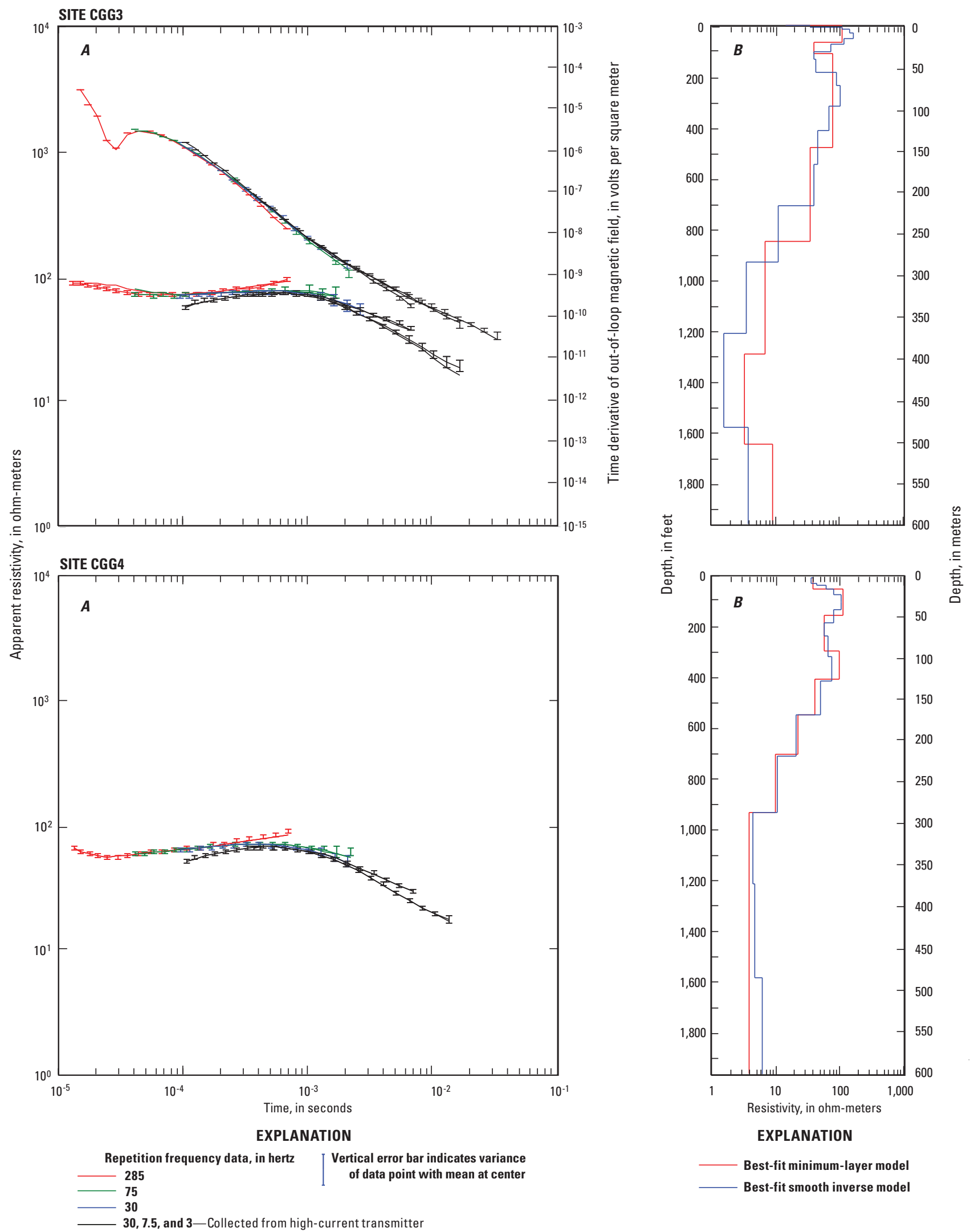

Figure 11. Relations between $A$, central-loop resistivity, out-of-loop vertical magnetic field (upper set of curves time-derivative, right axis for site CGG3), and time elapsed after primary current turnoff; and $B$, depth below land surface and subsurface resistivity modeled from time-domain electromagnetic sounding for sites CGG3 and CGG4. 
SITE CGG5

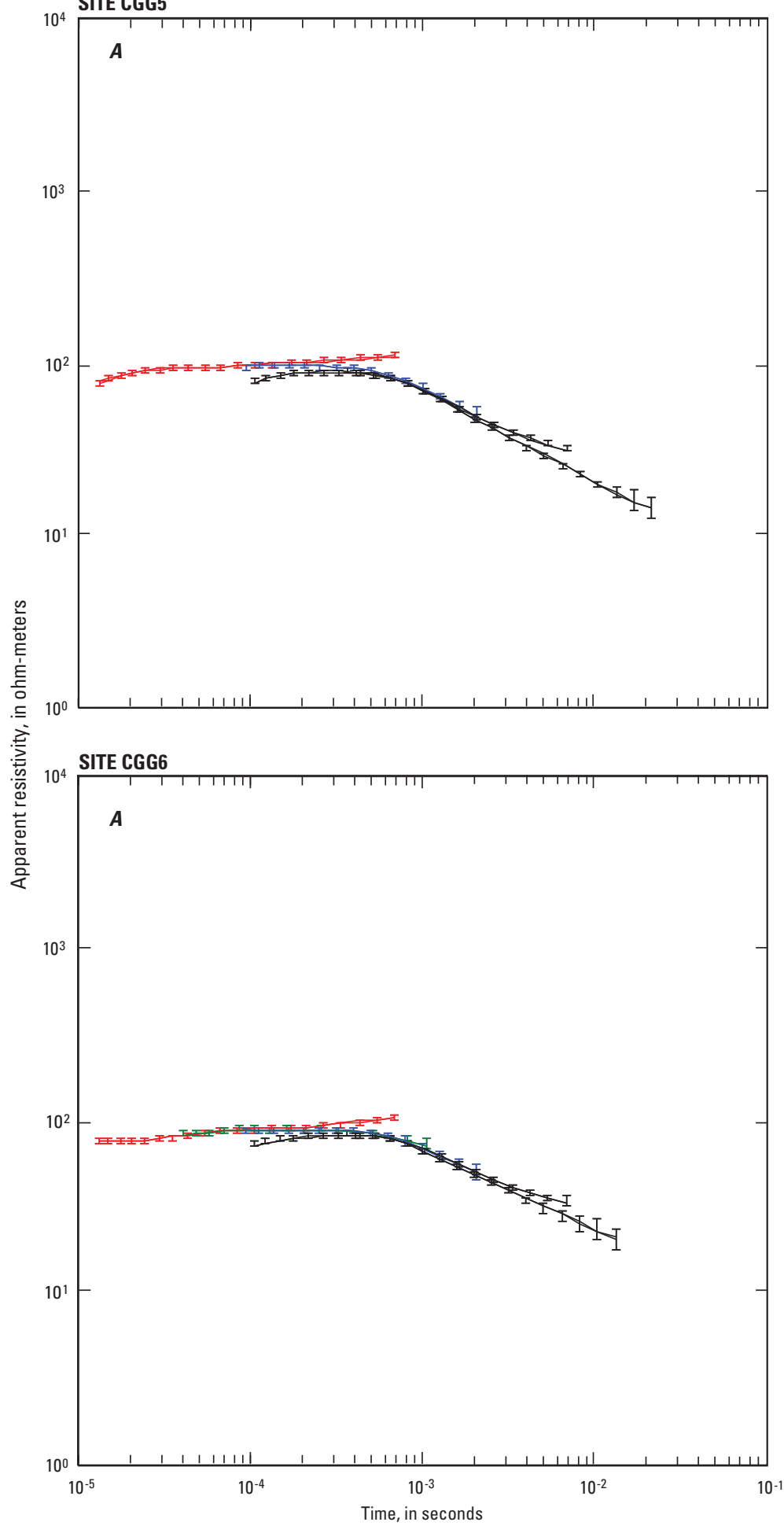

EXPLANATION

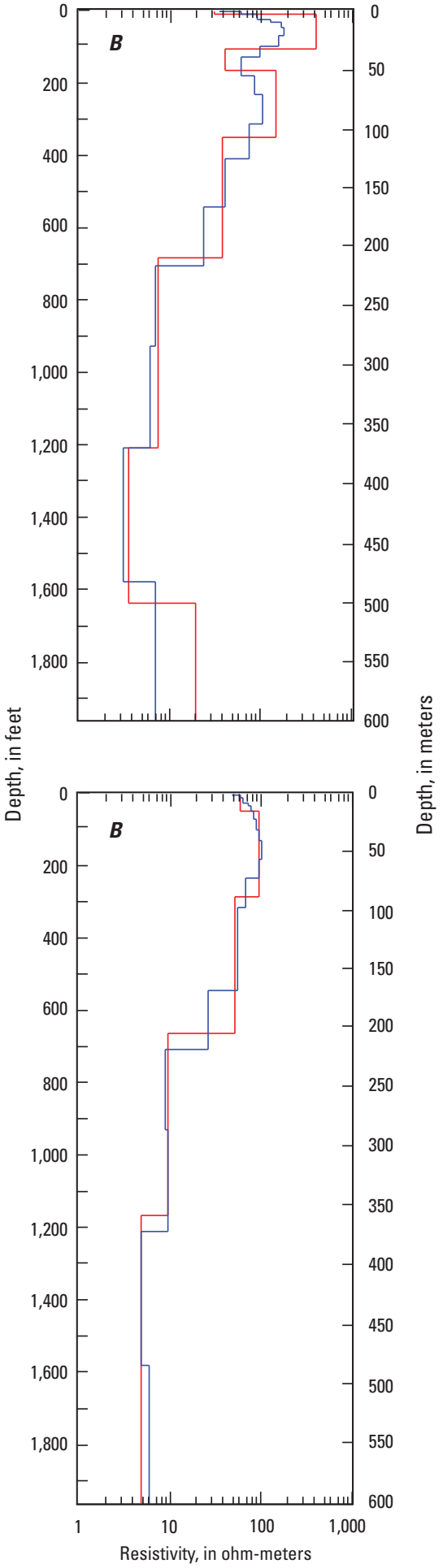

EXPLANATION

Best-fit minimum-layer model Best-fit smooth inverse model

Figure 12. Relations between $A$, central-loop resistivity and time elapsed after primary current turnoff; and $B$, depth below land surface and subsurface resistivity modeled from time-domain electromagnetic sounding for sites CGG5 and CGG6 

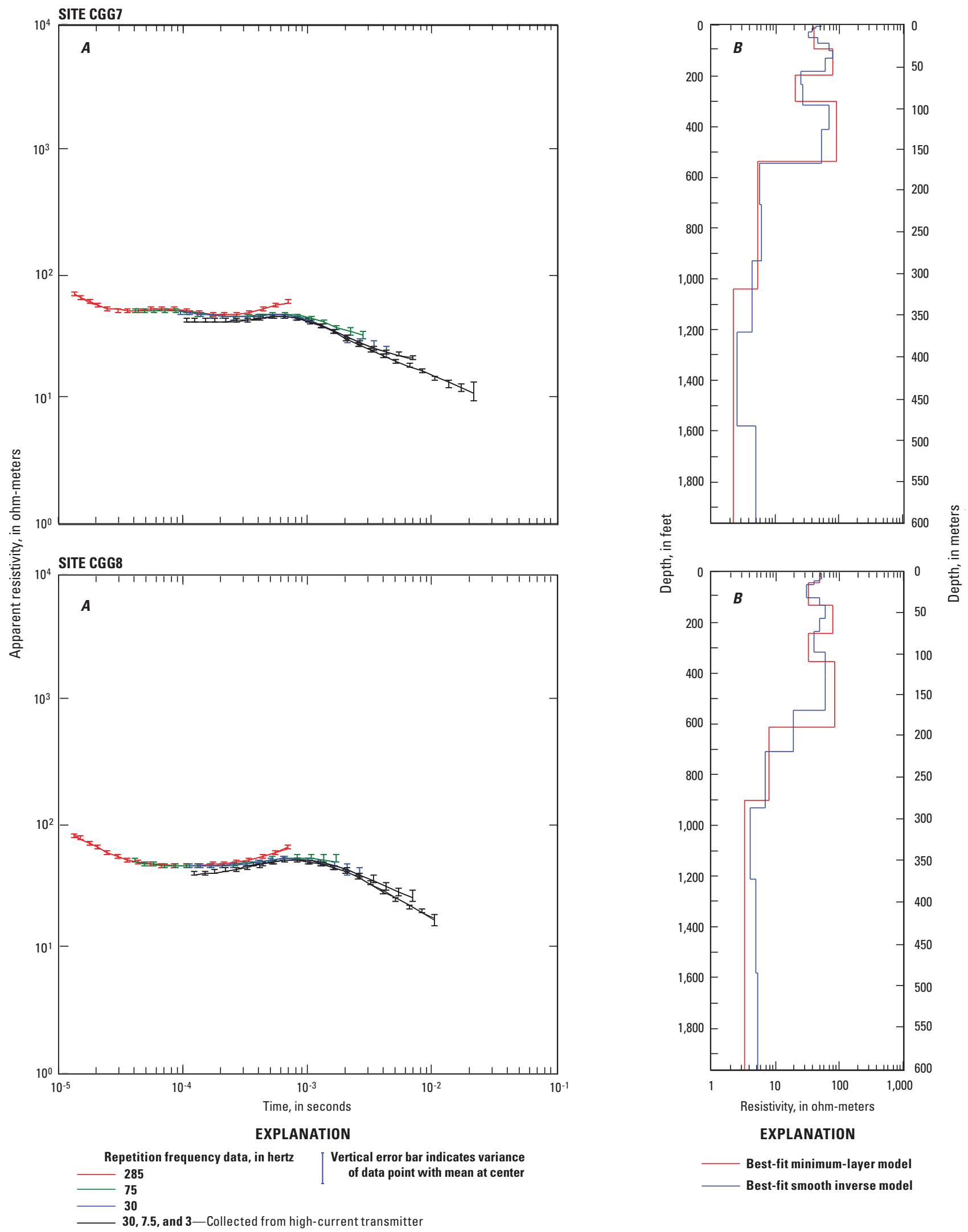

Figure 13. Relations between $A$, central-loop resistivity and time elapsed after primary current turnoff; and $B$, depth below land surface and subsurface resistivity modeled from time-domain electromagnetic sounding for sites CGG7 and CGG8. 

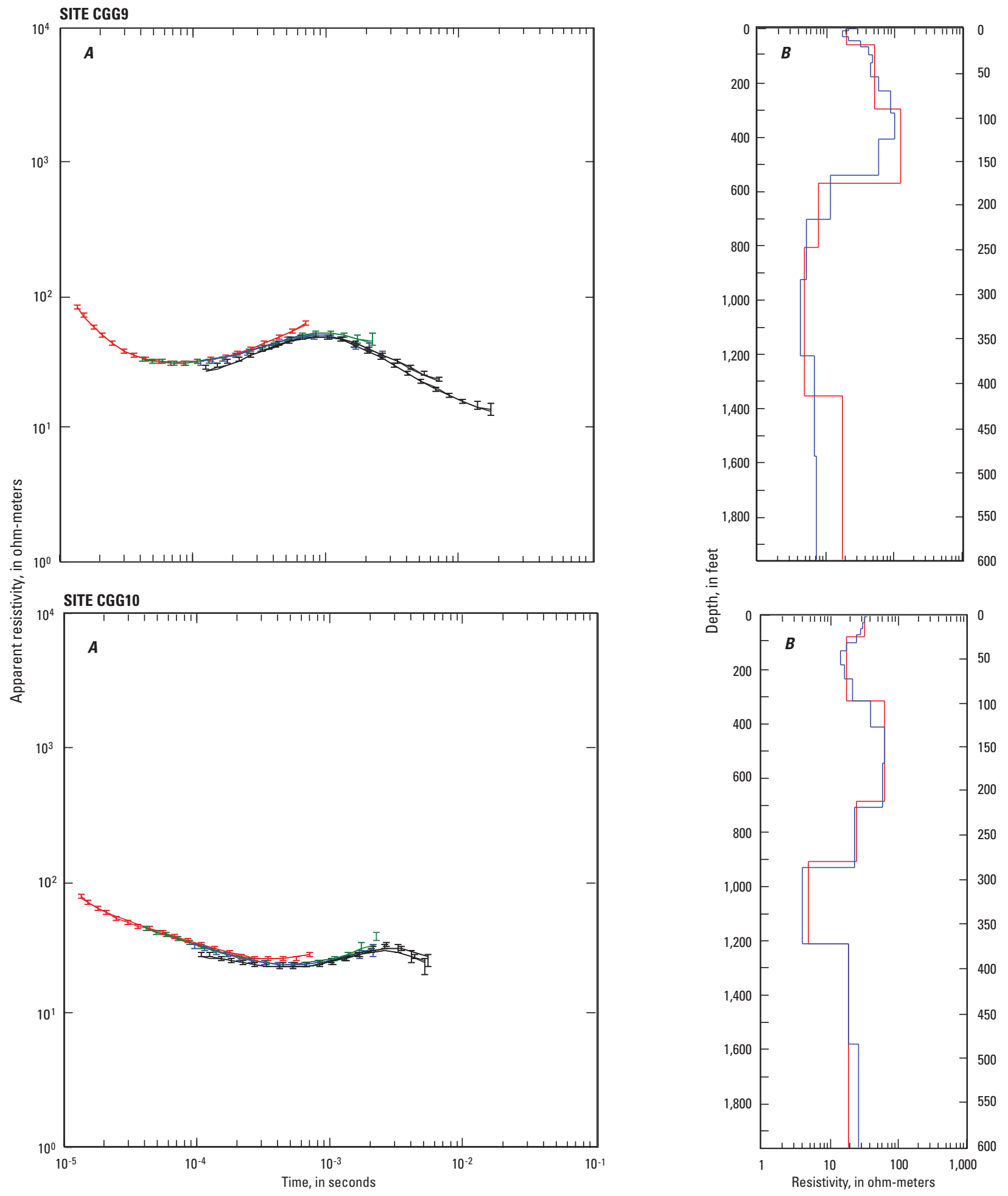

EXPLANATION

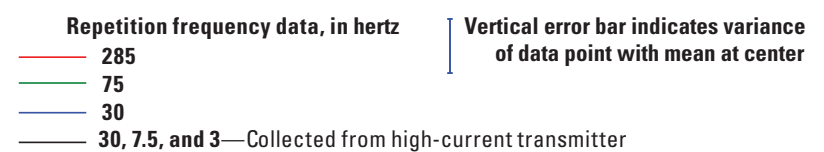

EXPLANATION

— Best-fit minimum-layer model _ Best-fit smooth inverse model

Figure 14. Relations between $A$, central-loop resistivity and time elapsed after primary current turnoff; and $B$, depth below land surface and subsurface resistivity modeled from time-domain electromagnetic sounding for sites CGG9 and CGG10. 

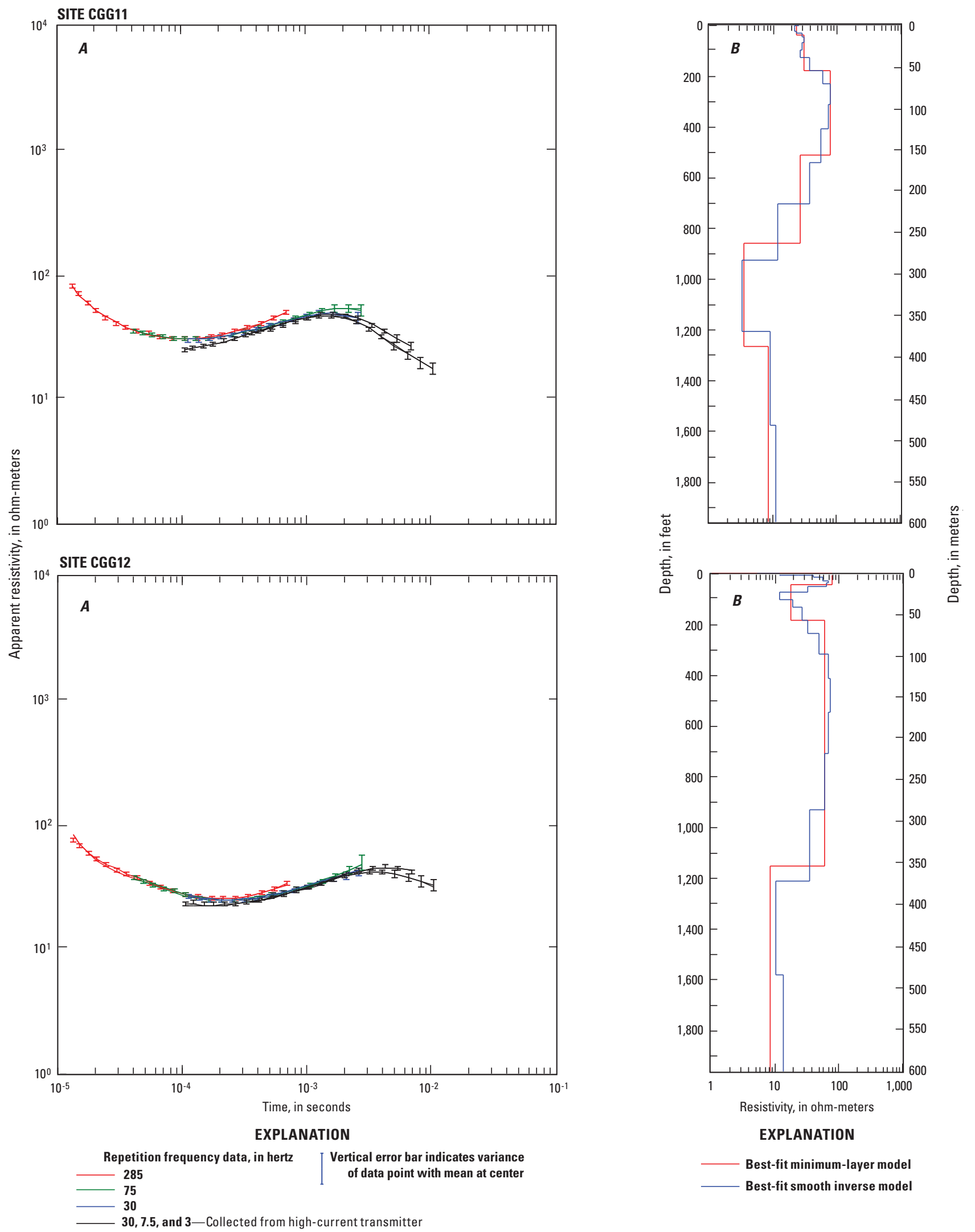

Figure 15. Relations between $A$, central-loop resistivity and time elapsed after primary current turnoff; and $B$, depth below land surface and subsurface resistivity modeled from time-domain electromagnetic sounding for sites CGG11 and CGG12. 
SITE CGG13

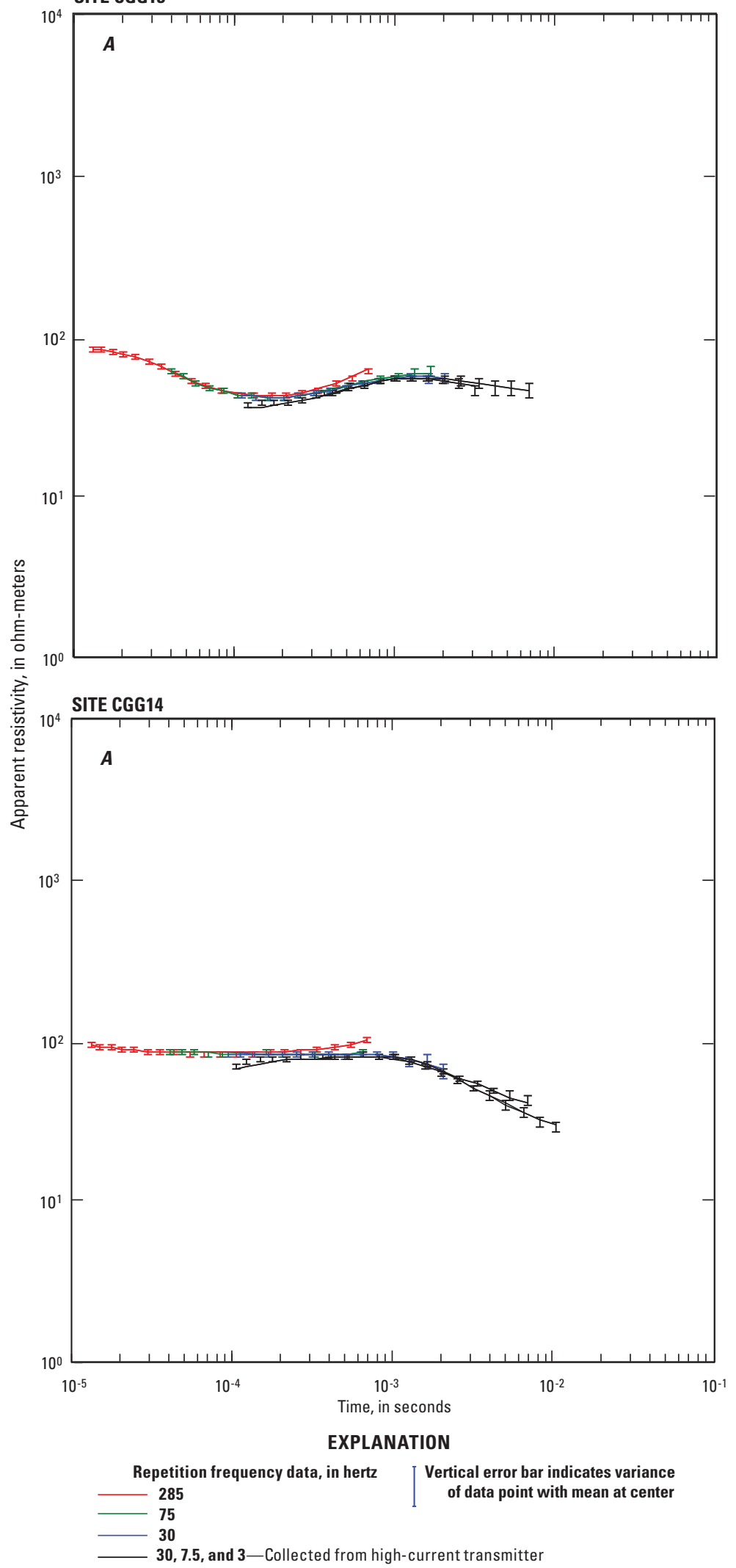

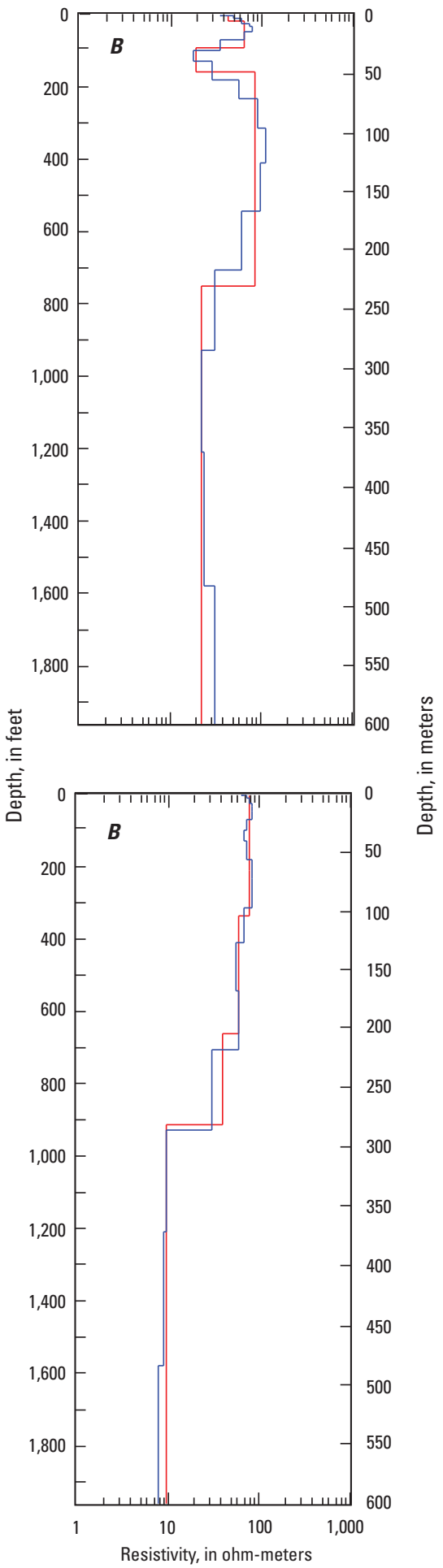

EXPLANATION

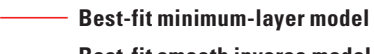

- Best-fit smooth inverse model

Figure 16. Relations between $A$, central-loop resistivity and time elapsed after primary current turnoff; and $B$, depth below land surface and subsurface resistivity modeled from time-domain electromagnetic sounding for sites CGG13 and CGG14. 

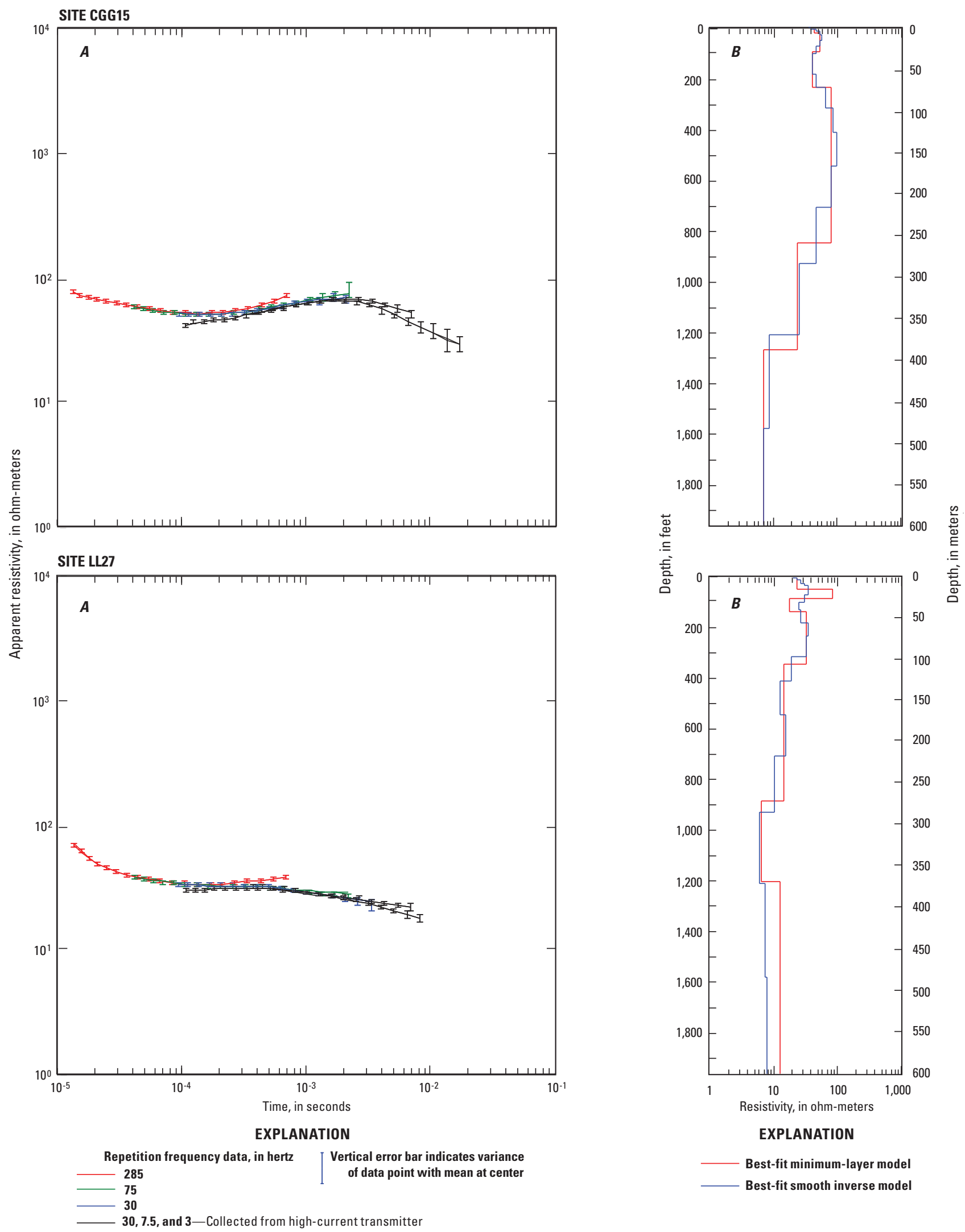

Figure 17. Relations between $A$, central-loop resistivity and time elapsed after primary current turnoff; and $B$, depth below land surface and subsurface resistivity modeled from time-domain electromagnetic sounding for sites CGG15 and LL27. 

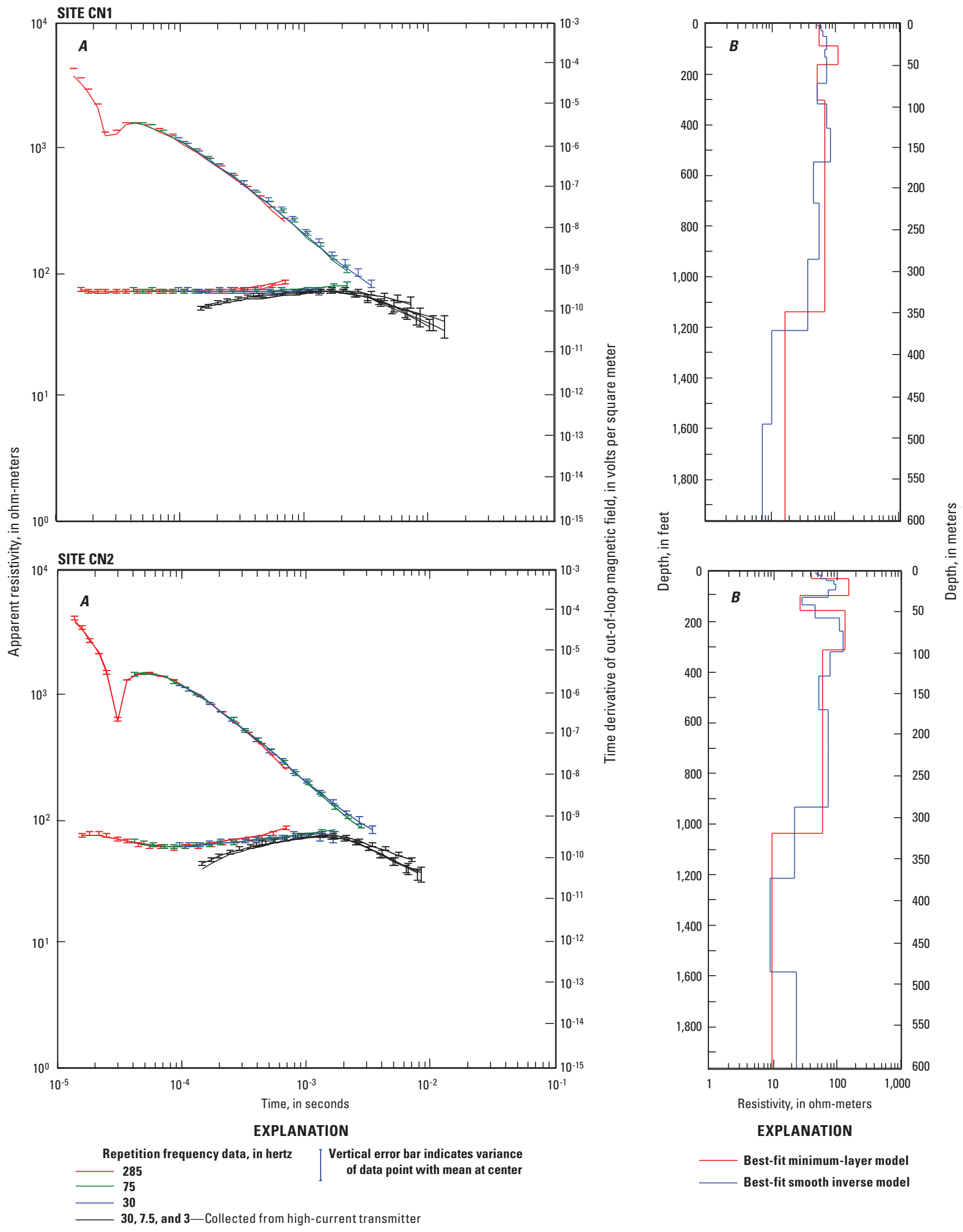

Figure 18. Relations between $A$, central-loop resistivity, out-of-loop vertical magnetic field (upper set of curves time-derivative, right axis), and time elapsed after primary current turnoff; and $B$, depth below land surface and subsurface resistivity modeled from time-domain electromagnetic sounding for sites CN1 and CN2. 

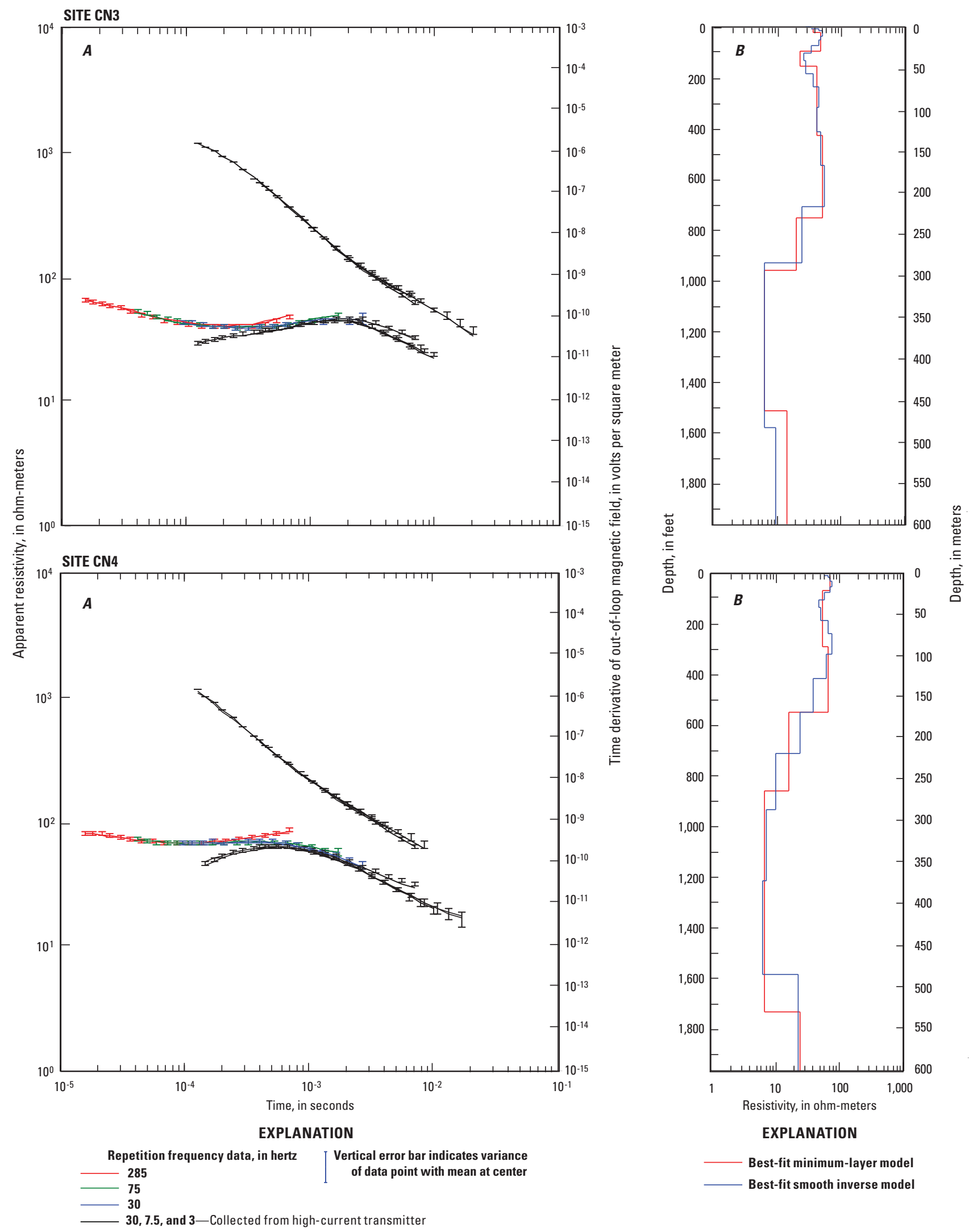

Figure 19. Relations between $A$, central-loop resistivity, out-of-loop vertical magnetic field (upper set of curves time-derivative, right axis), and time elapsed after primary current turnoff; and $B$, depth below land surface and subsurface resistivity modeled from time-domain electromagnetic sounding for sites CN3 and CN4. 

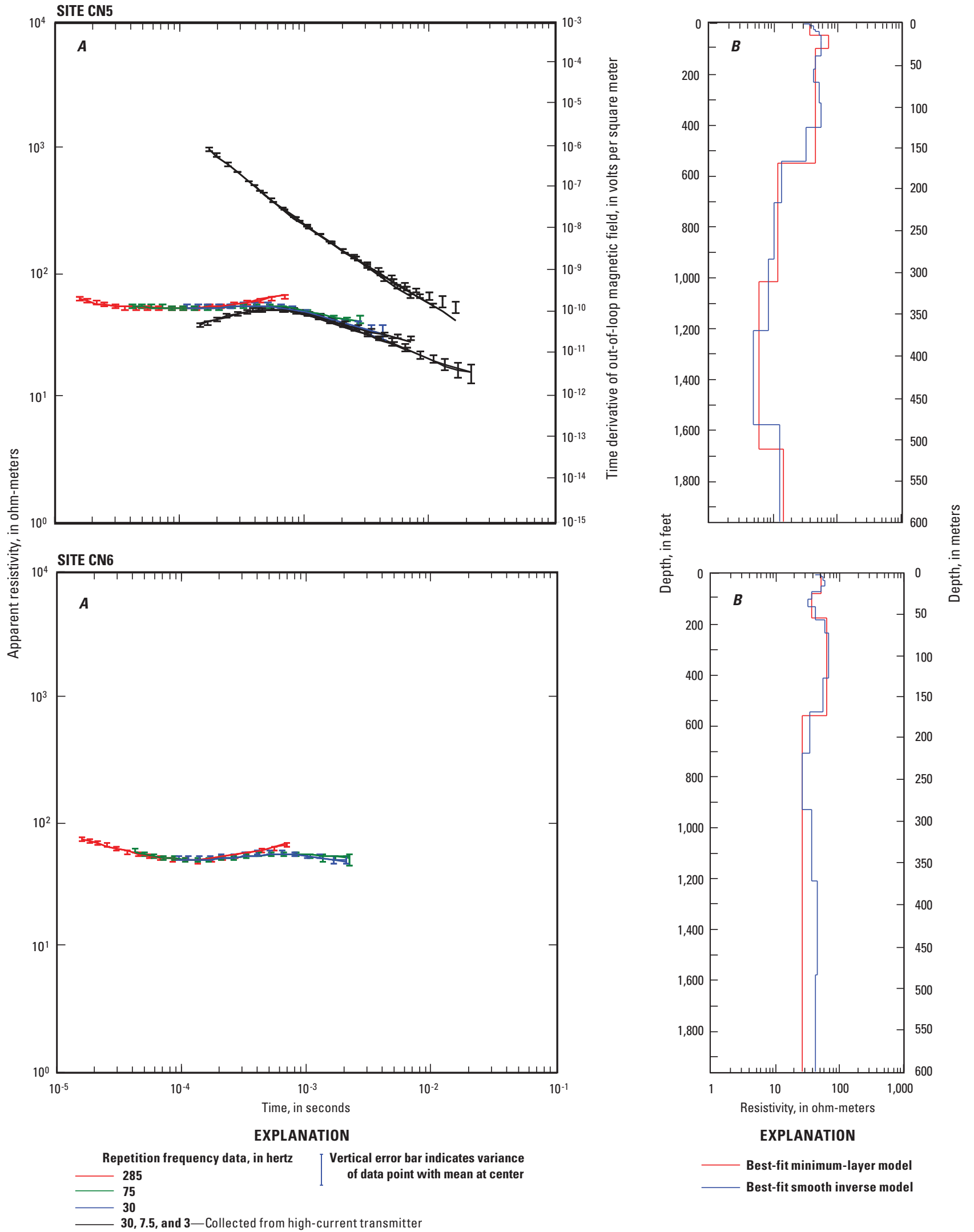

Figure 20. Relations between $A$, central-loop resistivity, out-of-loop vertical magnetic field (upper set of curves time-derivative, right axis for site $\mathrm{CN5}$ ), and time elapsed after primary current turnoff; and $B$, depth below land surface and subsurface resistivity modeled from time-domain electromagnetic sounding for sites CN5 and CN6. 


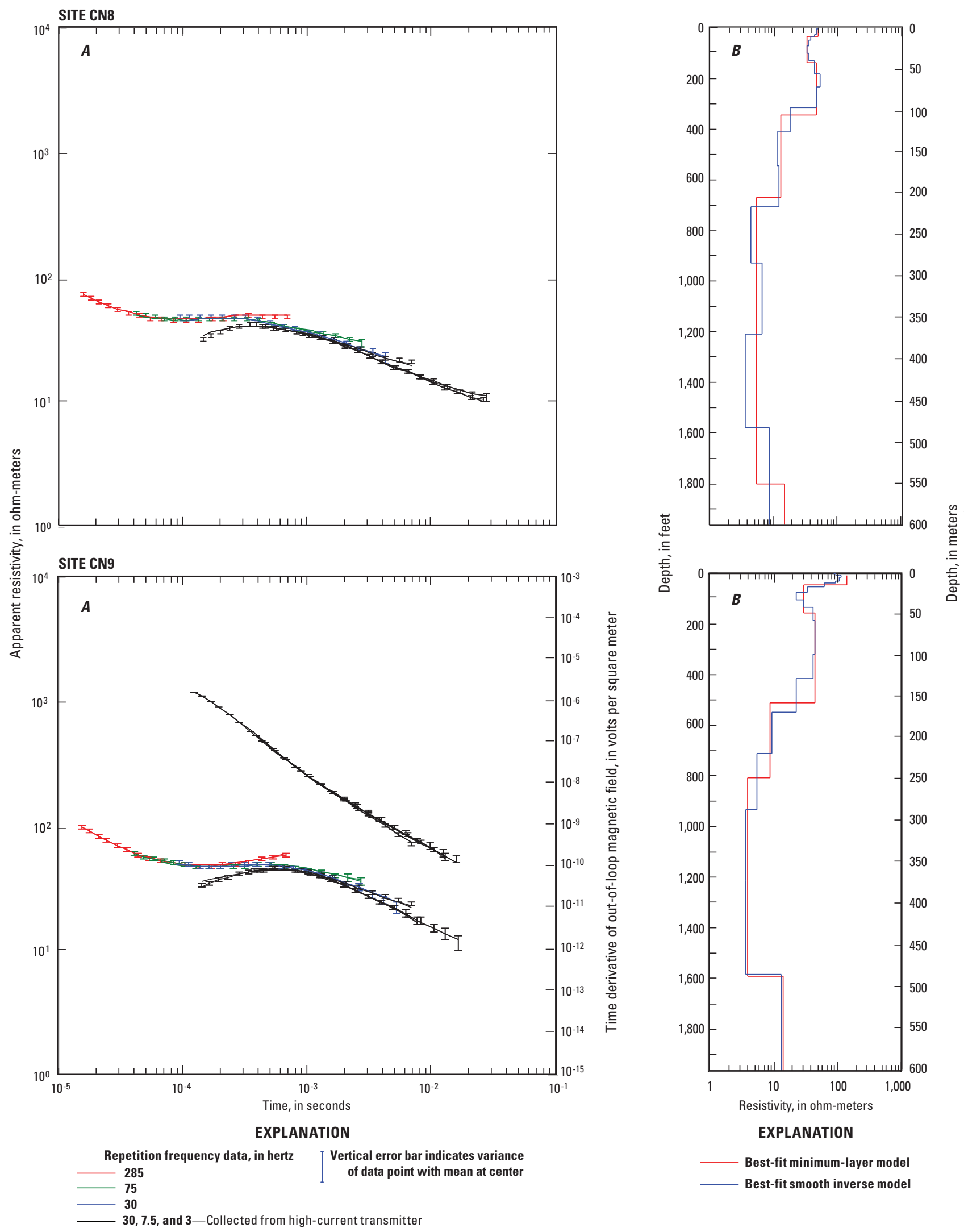

Figure 21. Relations between $A$, central-loop resistivity, out-of-loop vertical magnetic field (upper set of curves time-derivative, right axis for site $\mathrm{CN9}$ ), and time elapsed after primary current turnoff; and $B$, depth below land surface and subsurface resistivity modeled from time-domain electromagnetic sounding for sites CN8 and CN9. 


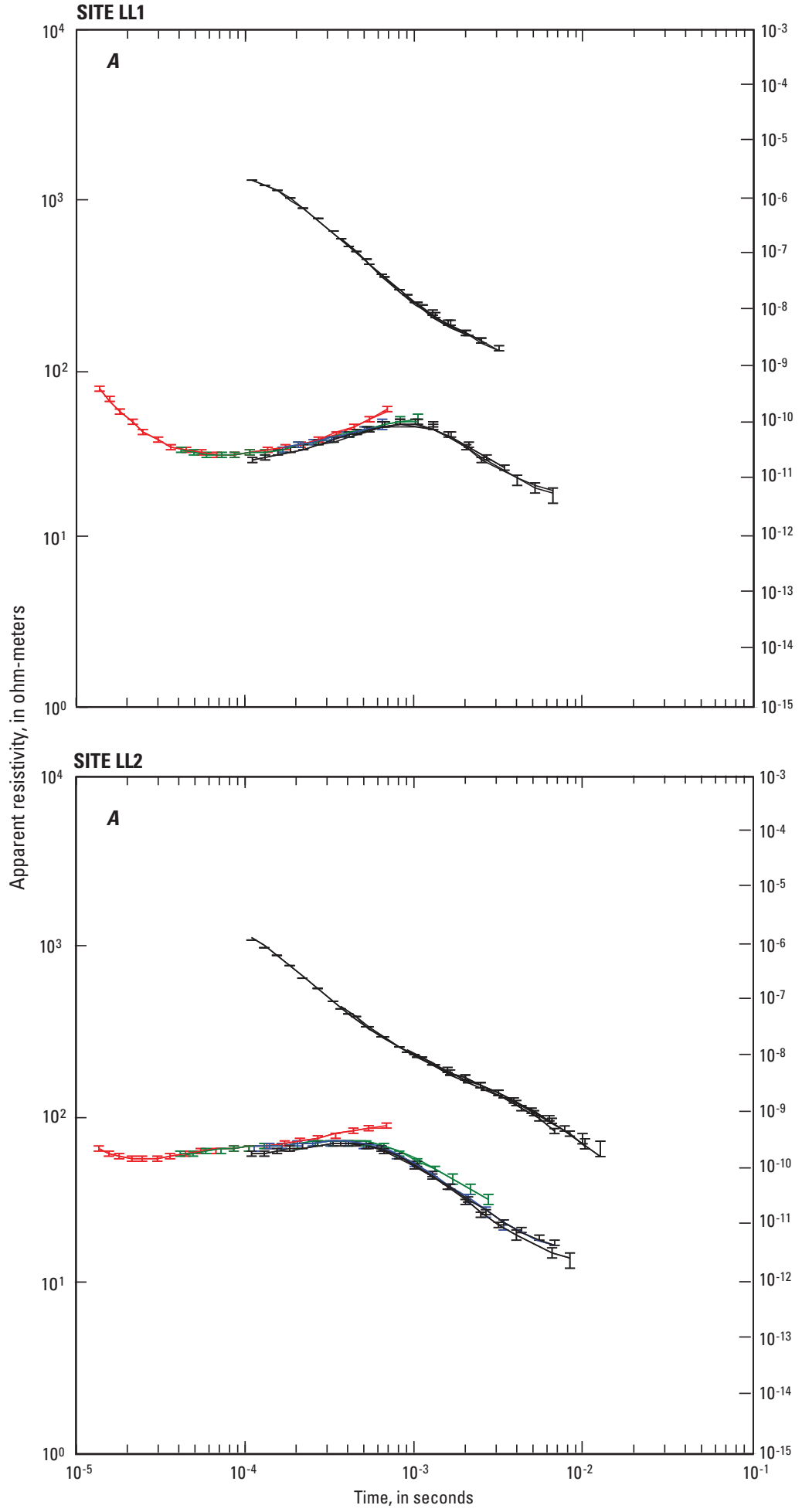

EXPLANATION

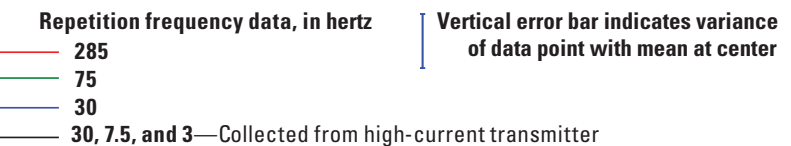

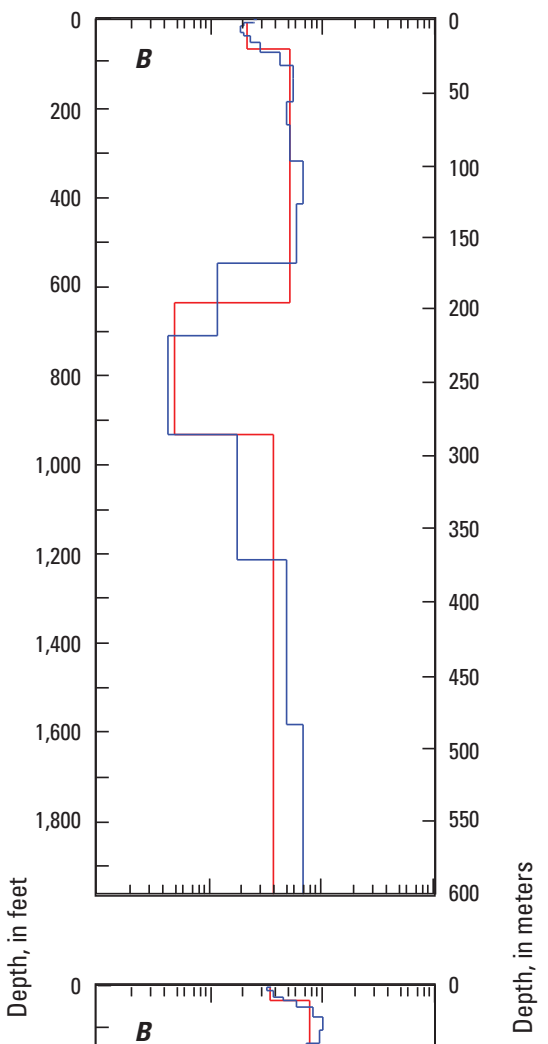

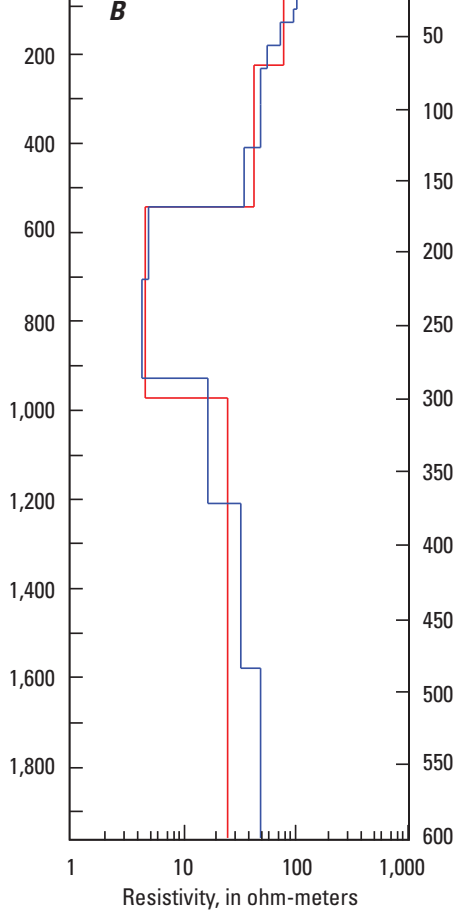

EXPLANATION

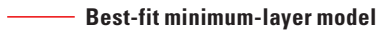

Best-fit smooth inverse model

Figure 22. Relations between $A$, central-loop resistivity, out-of-loop vertical magnetic field (upper set of curves time-derivative, right axis), and time elapsed after primary current turnoff; and $B$, depth below land surface and subsurface resistivity modeled from time-domain electromagnetic sounding for sites LL1 and LL2. 


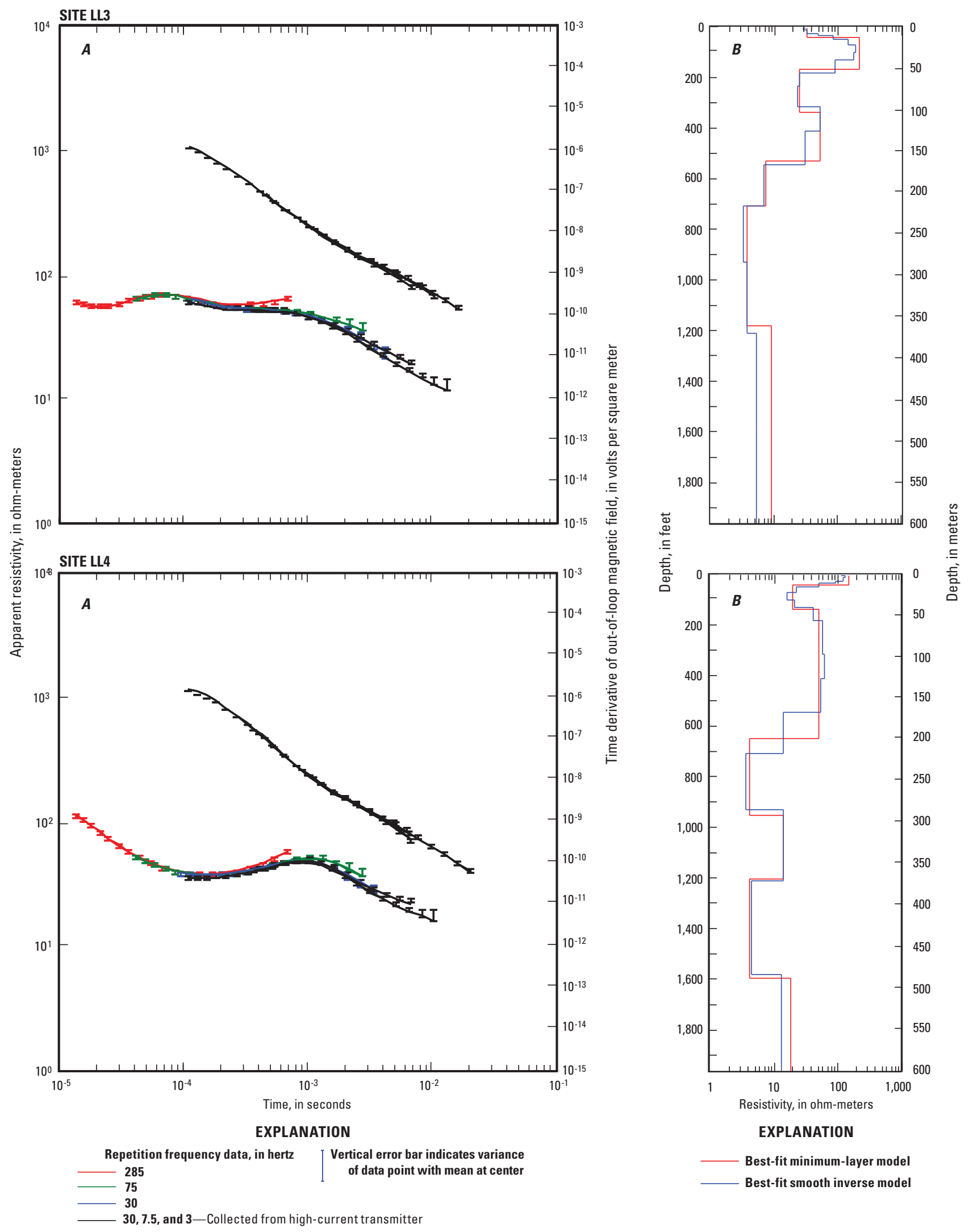

Figure 23. Relations between $A$, central-loop resistivity, out-of-loop vertical magnetic field (upper set of curves time-derivative, right axis), and time elapsed after primary current turnoff; and $B$, depth below land surface and subsurface resistivity modeled from time-domain electromagnetic sounding for sites LL3 and LL4. 

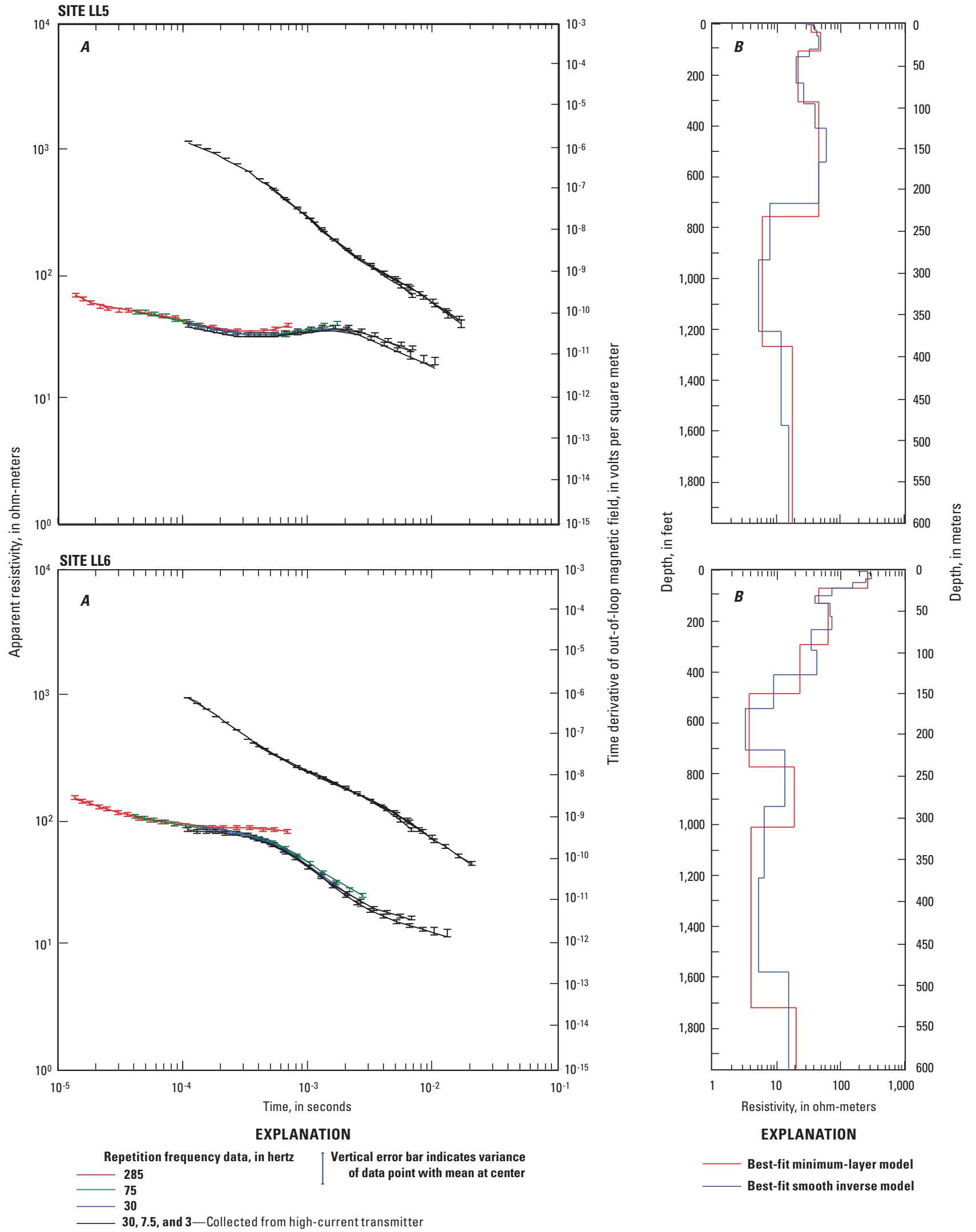

Figure 24. Relations between $A$, central-loop resistivity, out-of-loop vertical magnetic field (upper set of curves time-derivative, right axis), and time elapsed after primary current turnoff; and $B$, depth below land surface and subsurface resistivity modeled from time-domain electromagnetic sounding for sites LL5 and LL6. 


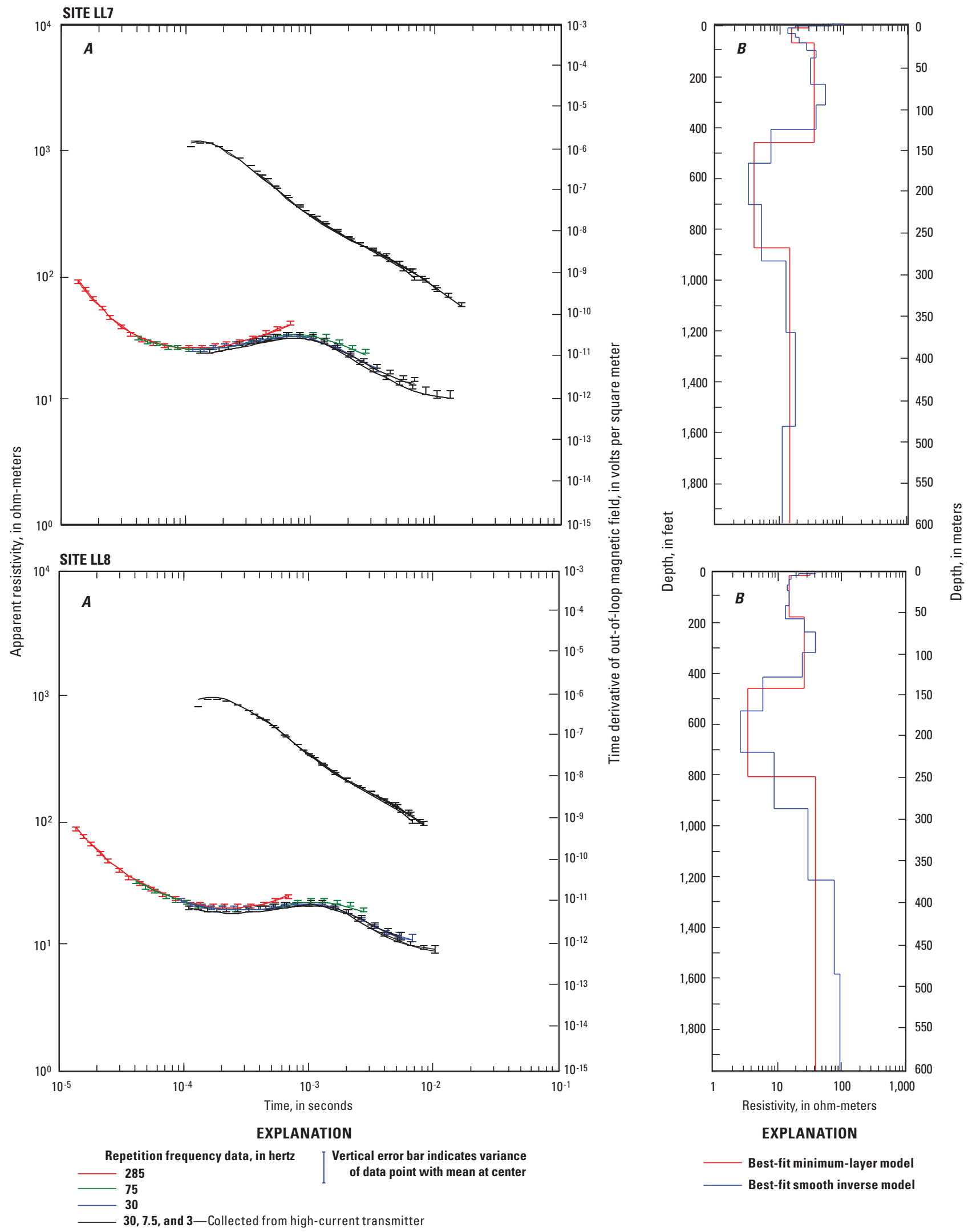

Figure 25. Relations between $A$, central-loop resistivity, out-of-loop vertical magnetic field (upper set of curves time-derivative, right axis), and time elapsed after primary current turnoff; and $B$, depth below land surface and subsurface resistivity modeled from time-domain electromagnetic sounding for sites LL7 and LL8. 
SITE LL9

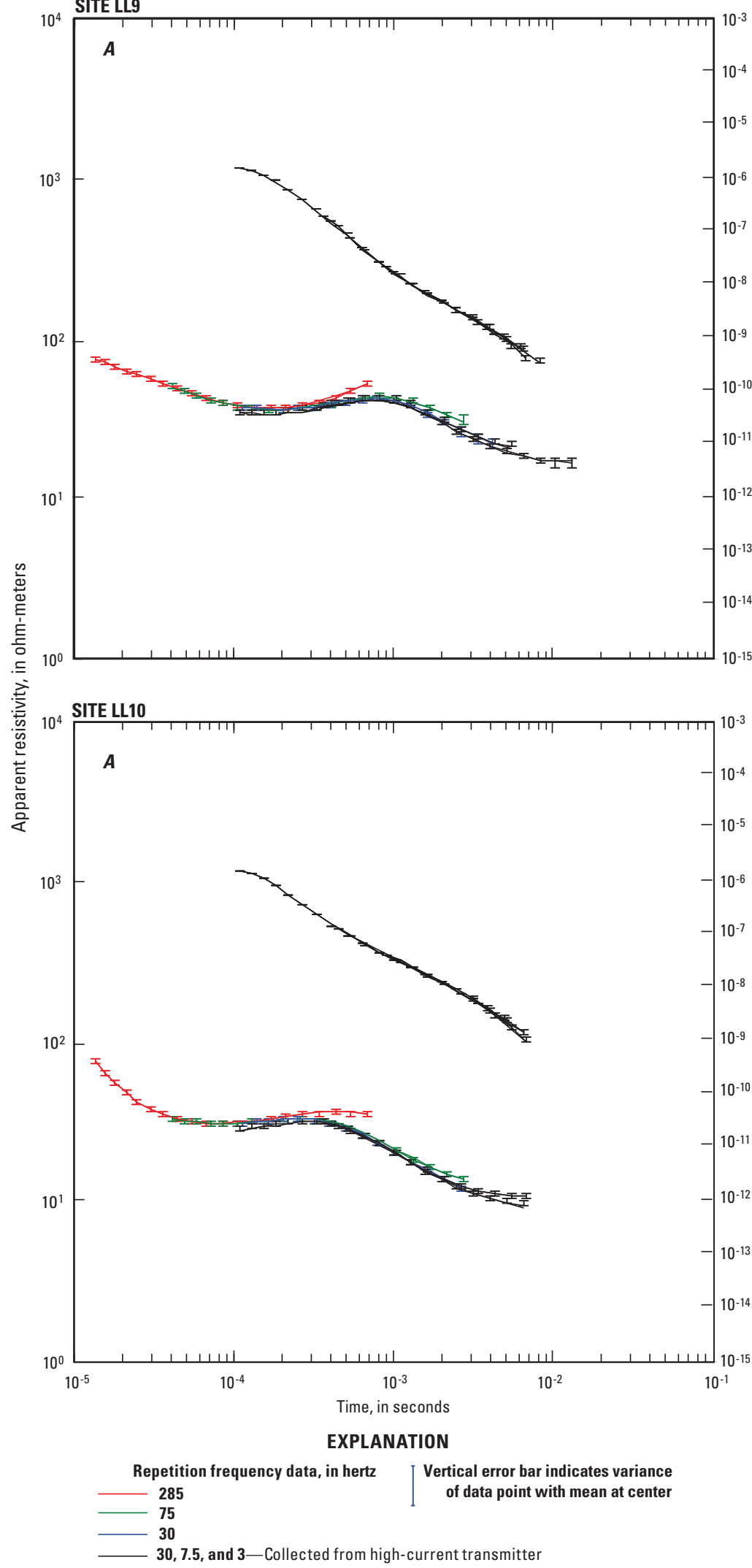

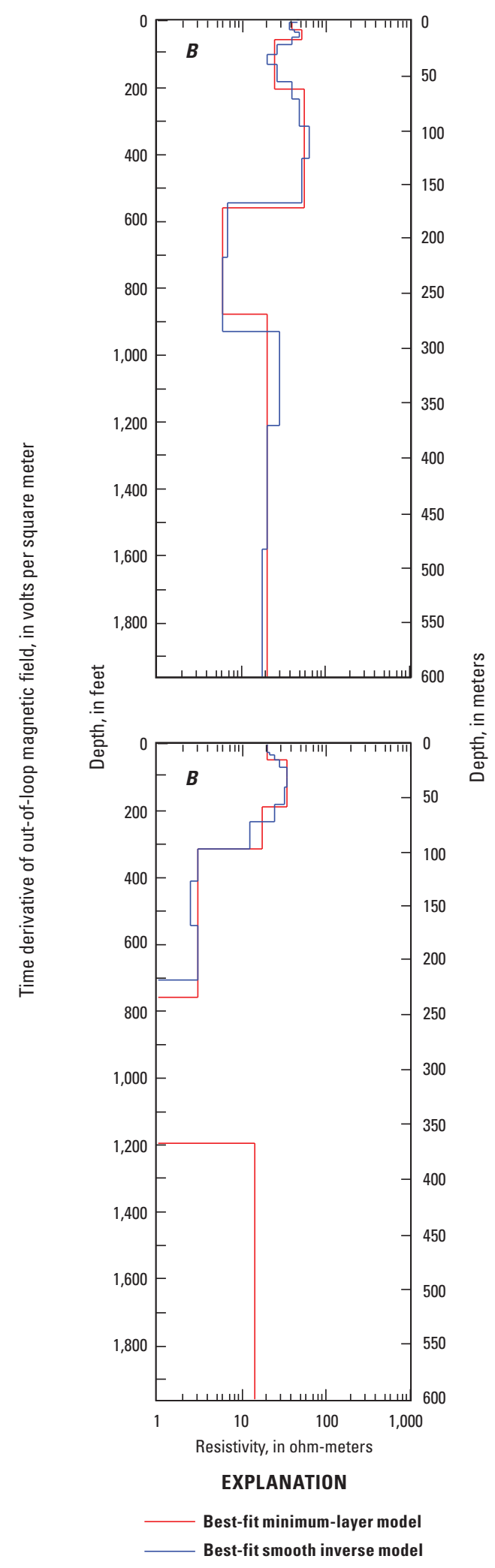

Figure 26. Relations between $A$, central-loop resistivity, out-of-loop vertical magnetic field (upper set of curves time-derivative, right axis), and time elapsed after primary current turnoff; and $B$, depth below land surface and subsurface resistivity modeled from time-domain electromagnetic sounding for sites LL9 and LL10. 

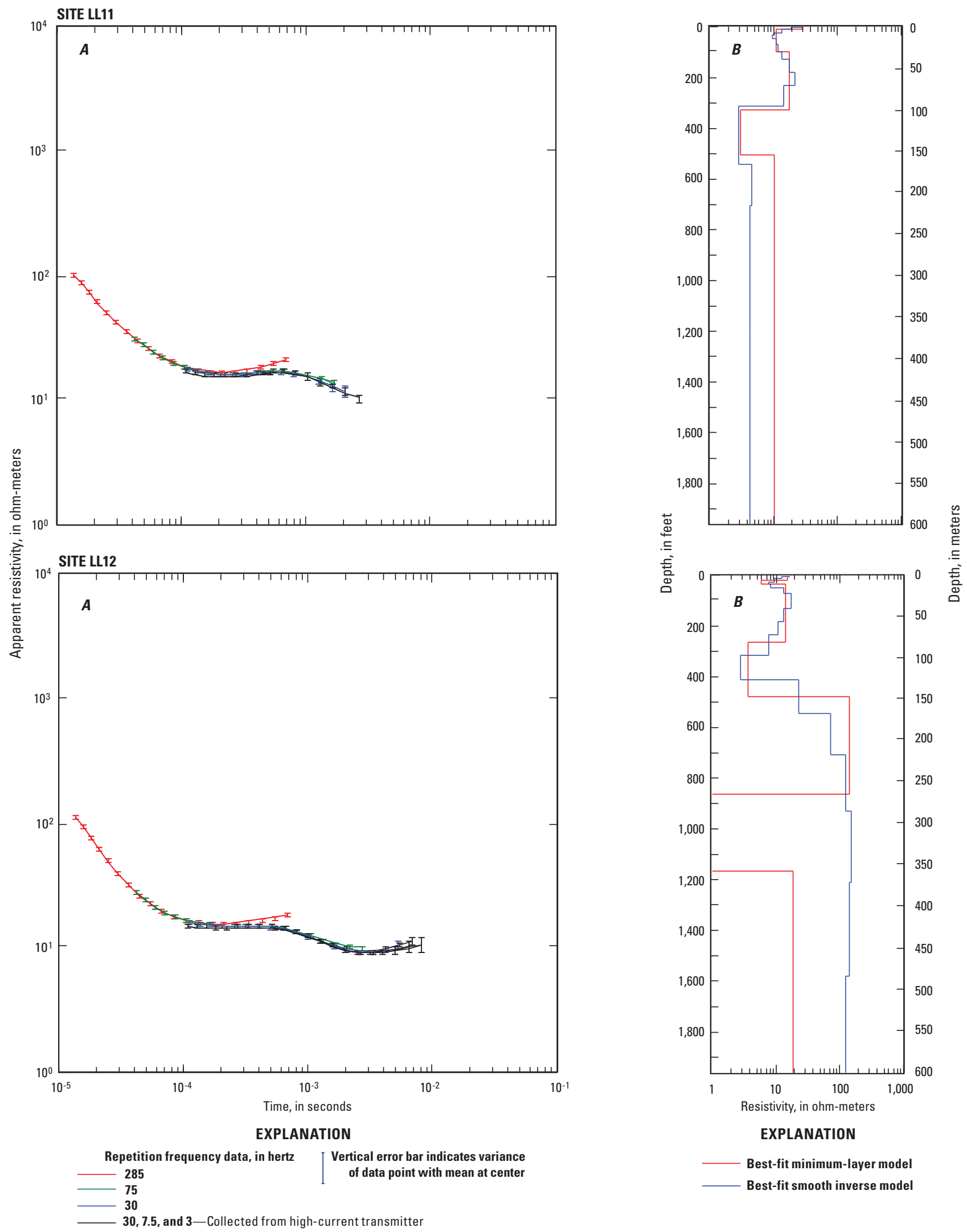

Figure 27. Relations between $A$, central-loop resistivity and time elapsed after primary current turnoff; and $B$, depth below land surface and subsurface resistivity modeled from time-domain electromagnetic sounding for sites LL11 and LL12. 


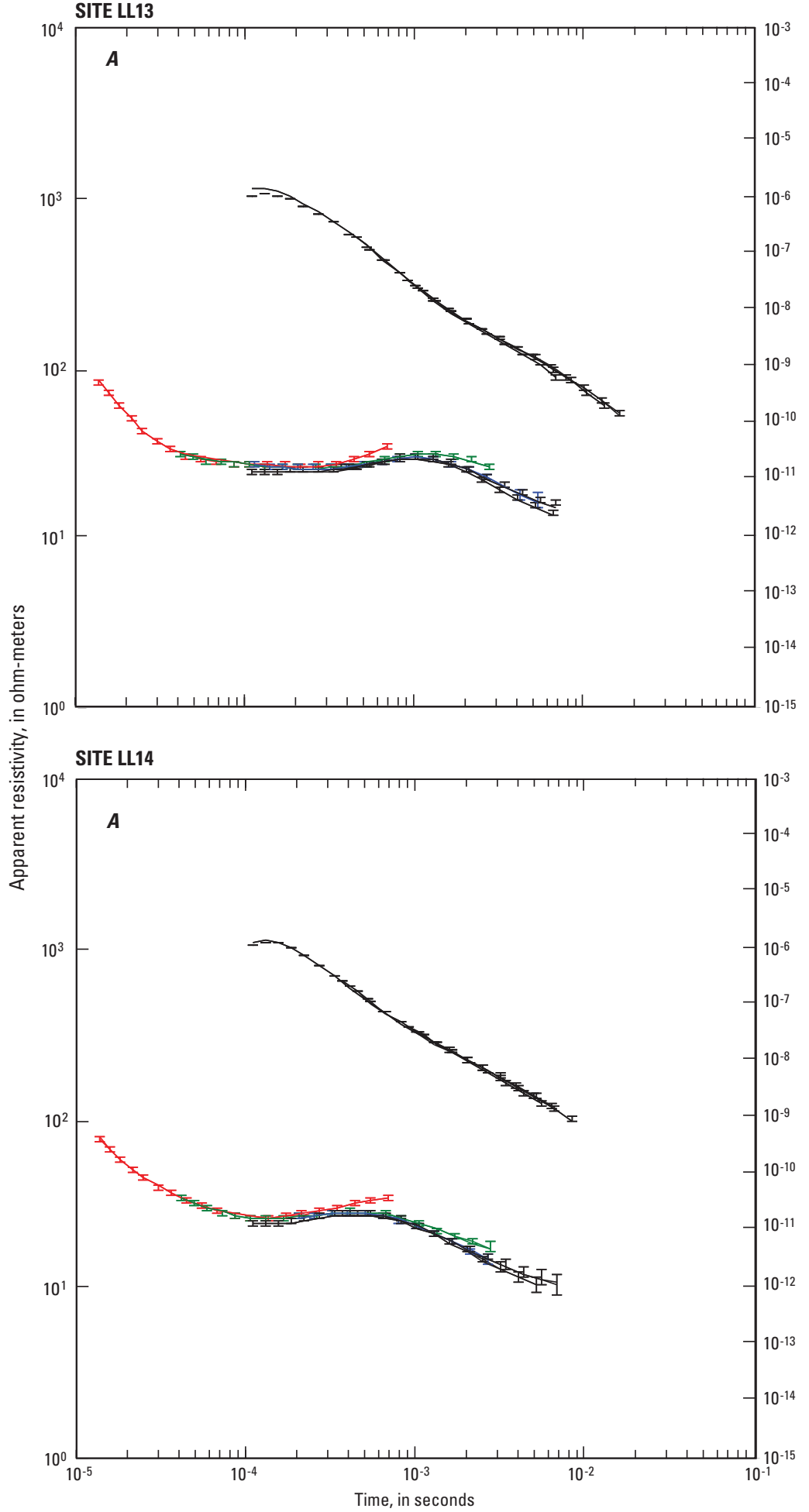

EXPLANATION

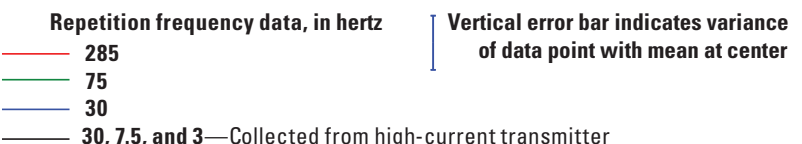

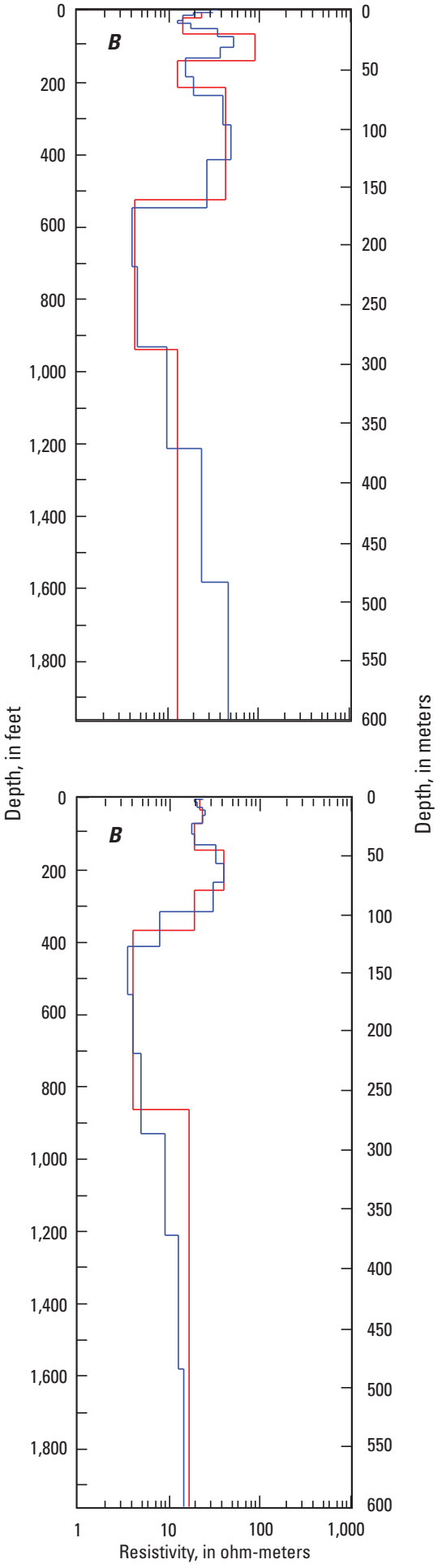

EXPLANATION

Best-fit minimum-layer model

_ Best-fit smooth inverse model

Figure 28. Relations between $A$, central-loop resistivity, out-of-loop vertical magnetic field (upper set of curves time-derivative, right axis), and time elapsed after primary current turnoff; and $B$, depth below land surface and subsurface resistivity modeled from time-domain electromagnetic sounding for sites LL13 and LL14. 
SITE LL15

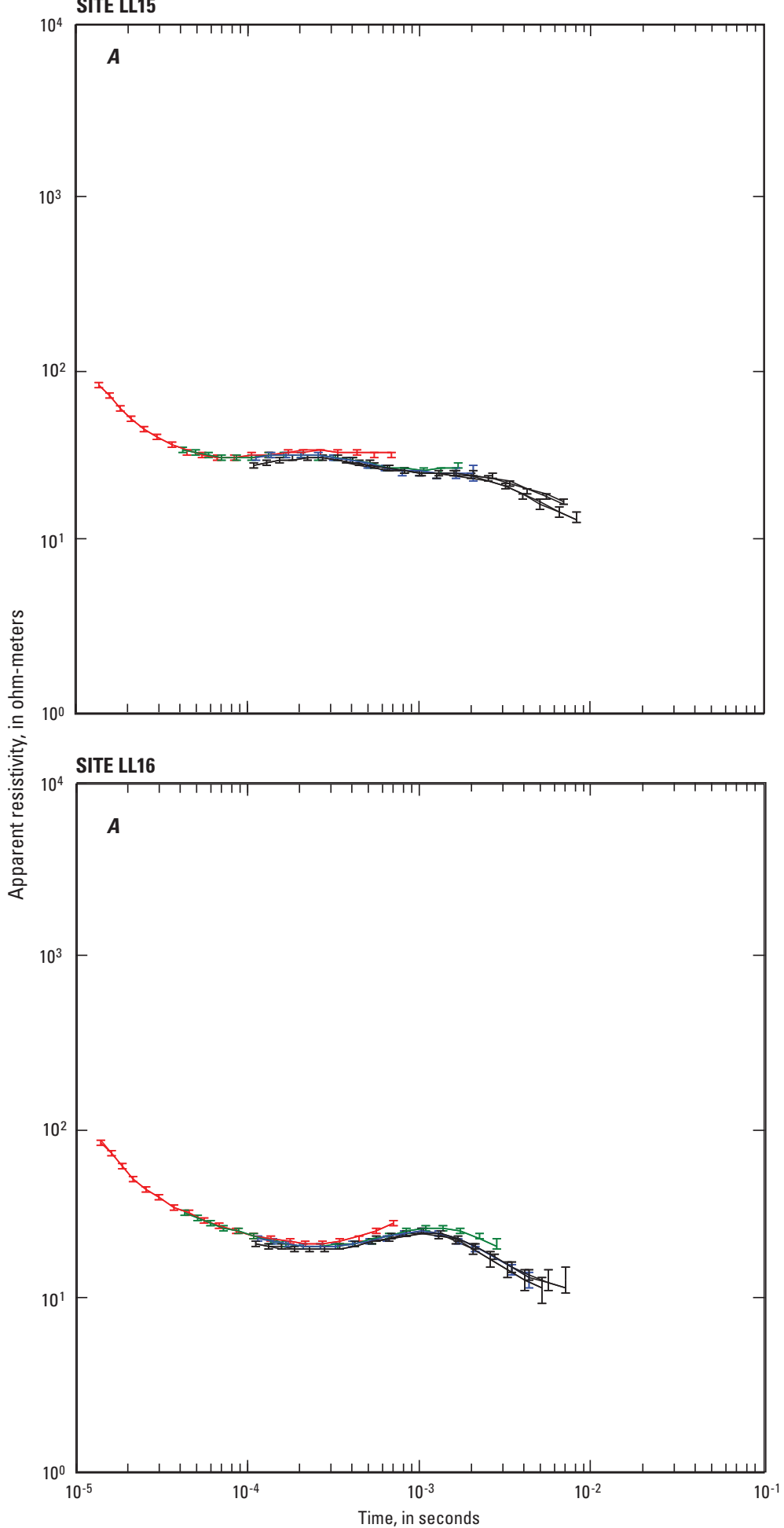

EXPLANATION

Repetition frequency data, in hertz $\quad$ T Vertical error bar indicates variance

285

75
30

30, 7.5, and 3-Collected from high-current transmitter

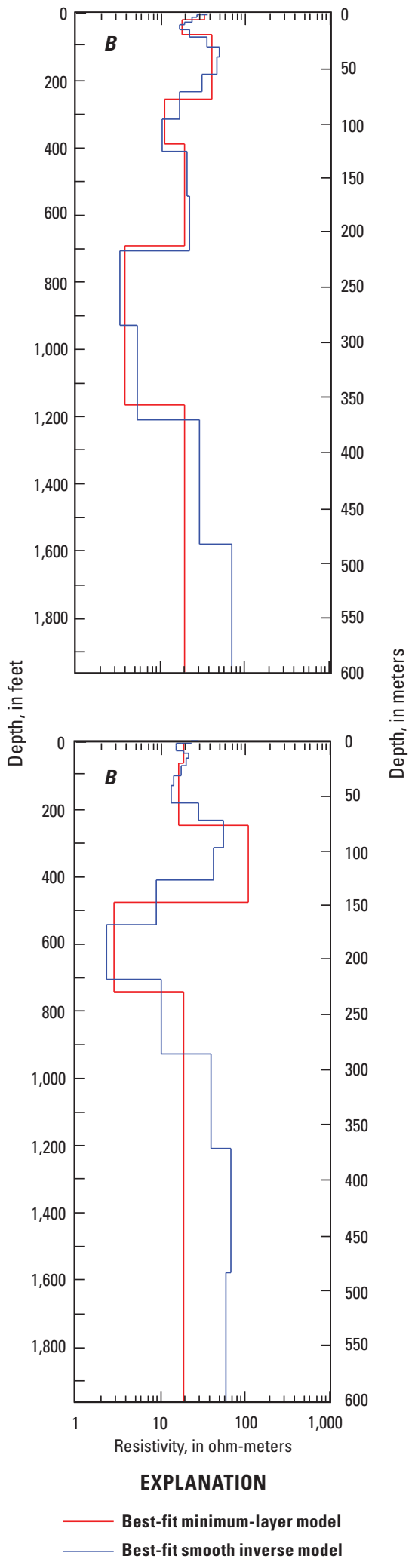

Figure 29. Relations between $A$, central-loop resistivity and time elapsed after primary current turnoff; and $B$, depth below land surface and subsurface resistivity modeled from time-domain electromagnetic sounding for sites LL15 and LL16. 

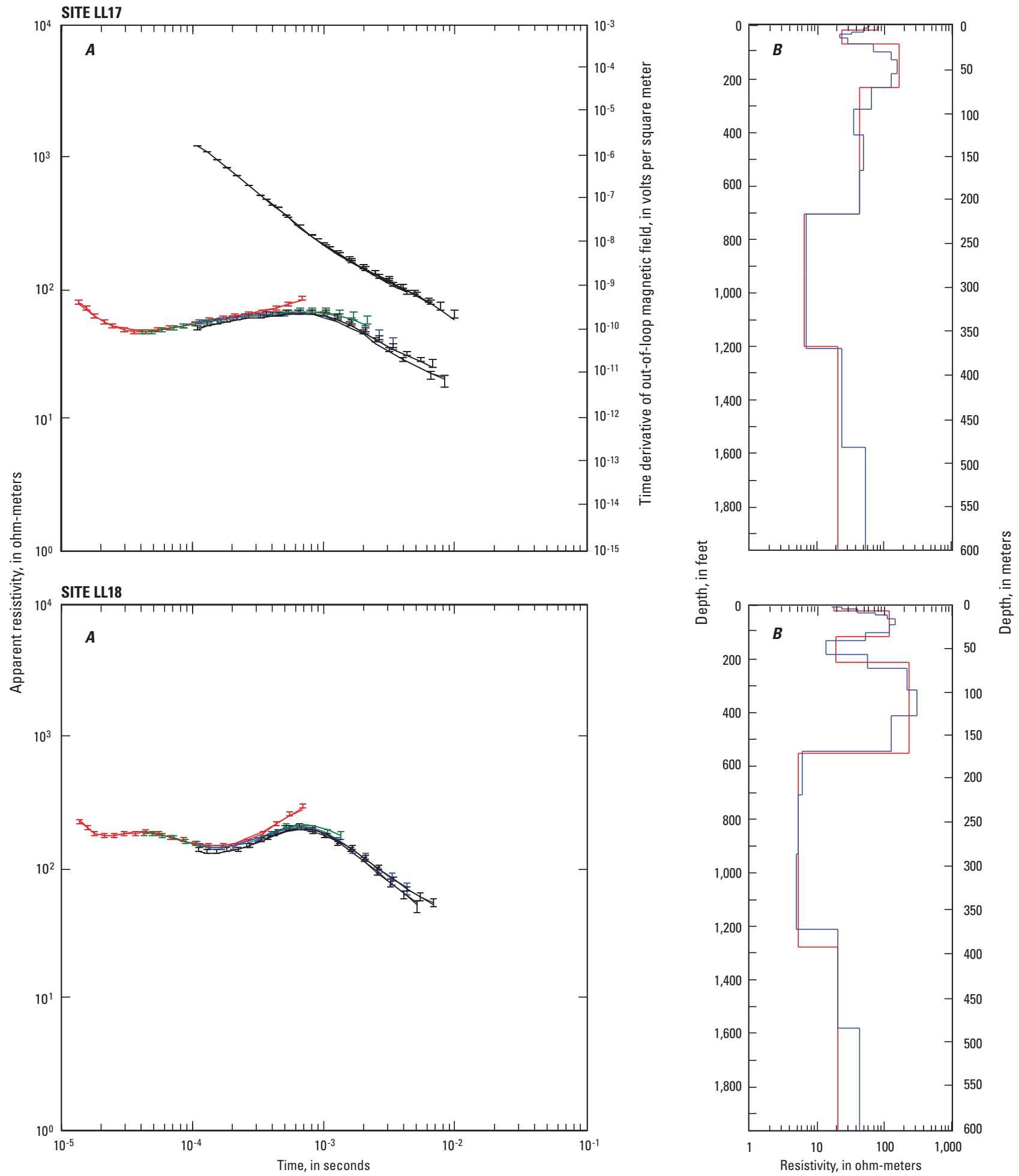

EXPLANATION

EXPLANATION

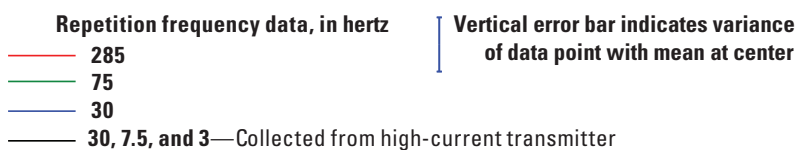

Best-fit minimum-layer model
Best-fit smooth inverse model

Figure 30. Relations between $A$, central-loop resistivity, out-of-loop vertical magnetic field (upper set of curves time-derivative, right axis for site LL17), and time elapsed after primary current turnoff; and $B$, depth below land surface and subsurface resistivity modeled from time-domain electromagnetic sounding for sites LL17 and LL18. 

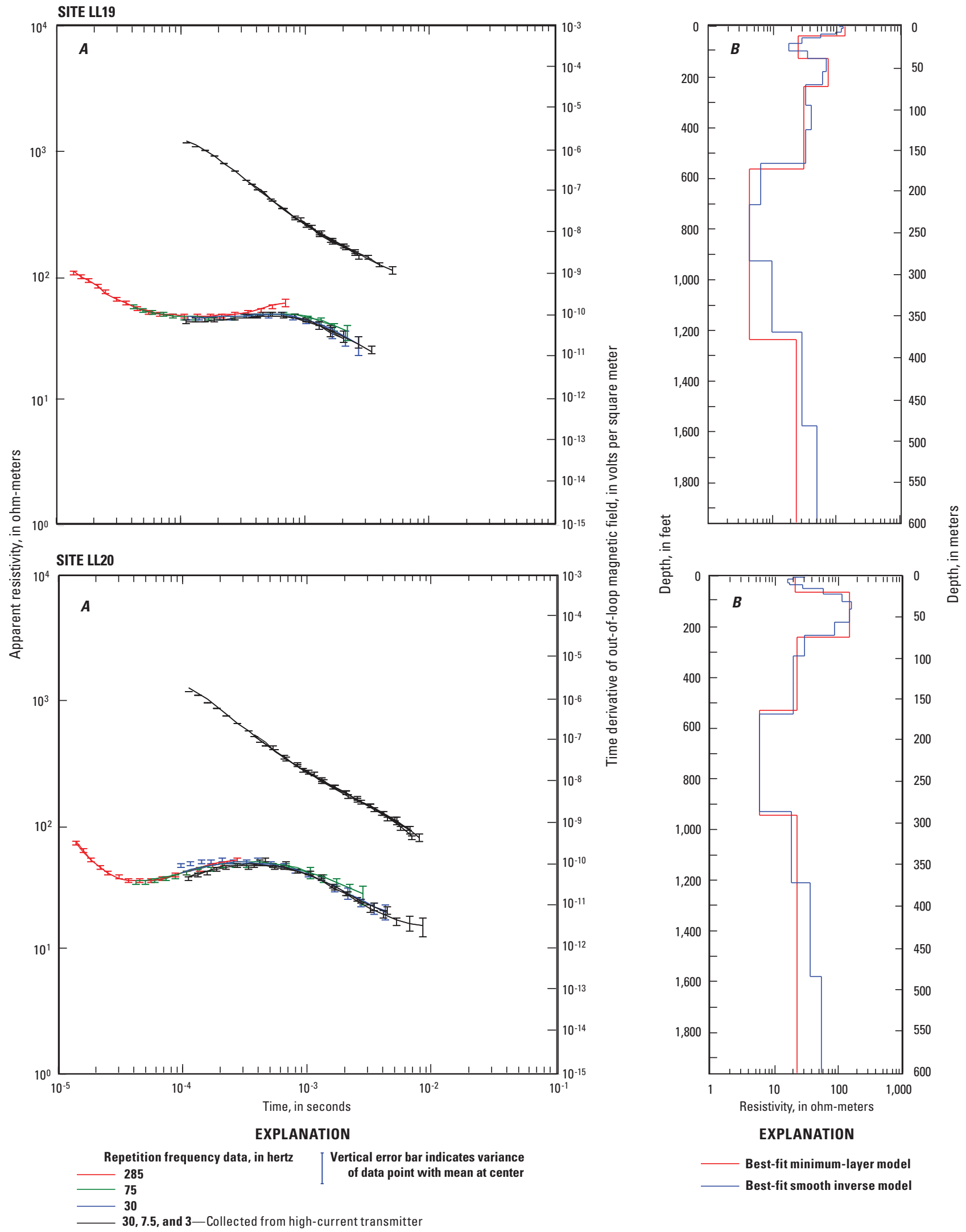

Figure 31. Relations between $A$, central-loop resistivity, out-of-loop vertical magnetic field (upper set of curves time-derivative, right axis), and time elapsed after primary current turnoff; and $B$, depth below land surface and subsurface resistivity modeled from time-domain electromagnetic sounding for sites LL19 and LL20. 
SITE LL21

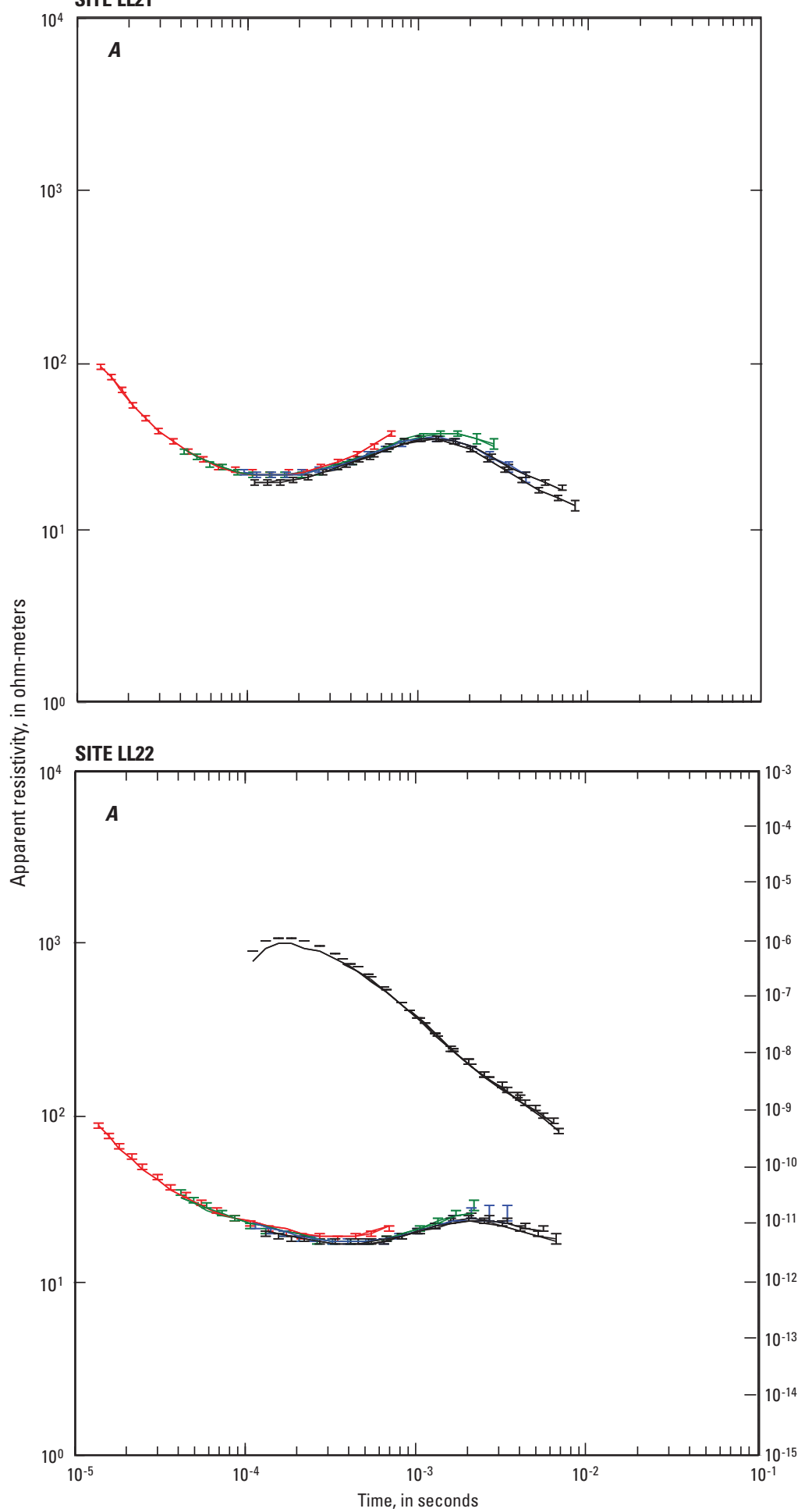

EXPLANATION

Repetition frequency data, in hertz 285

75

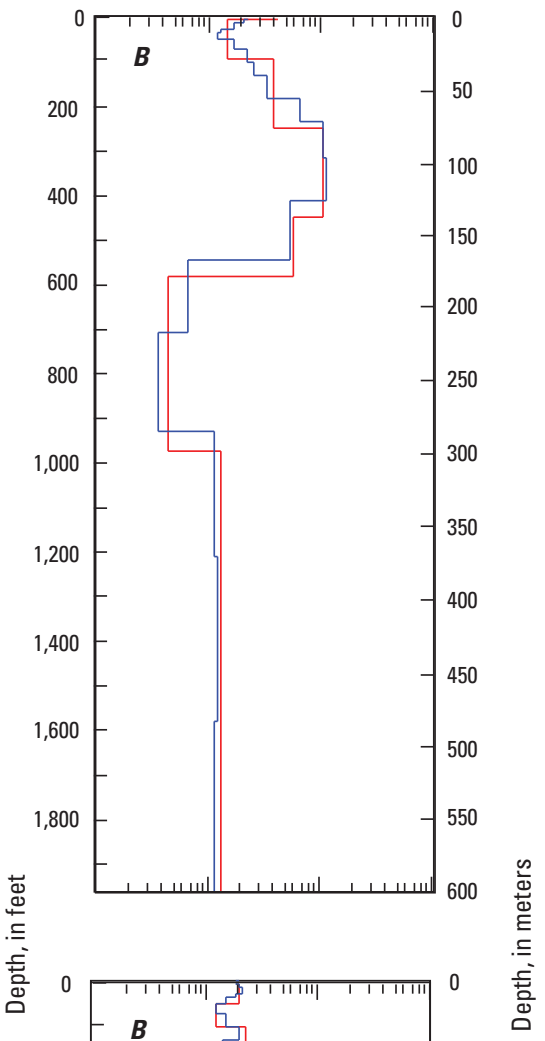

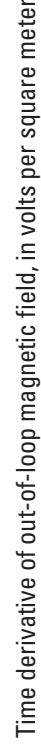

Figure 32. Relations between $A$, central-loop resistivity, out-of-loop vertical magnetic field (upper set of curves time-derivative, right axis for site LL22), and time elapsed after primary current turnoff; and $B$, depth below land surface and subsurface resistivity modeled from time-domain electromagnetic sounding for sites LL21 and LL22. 

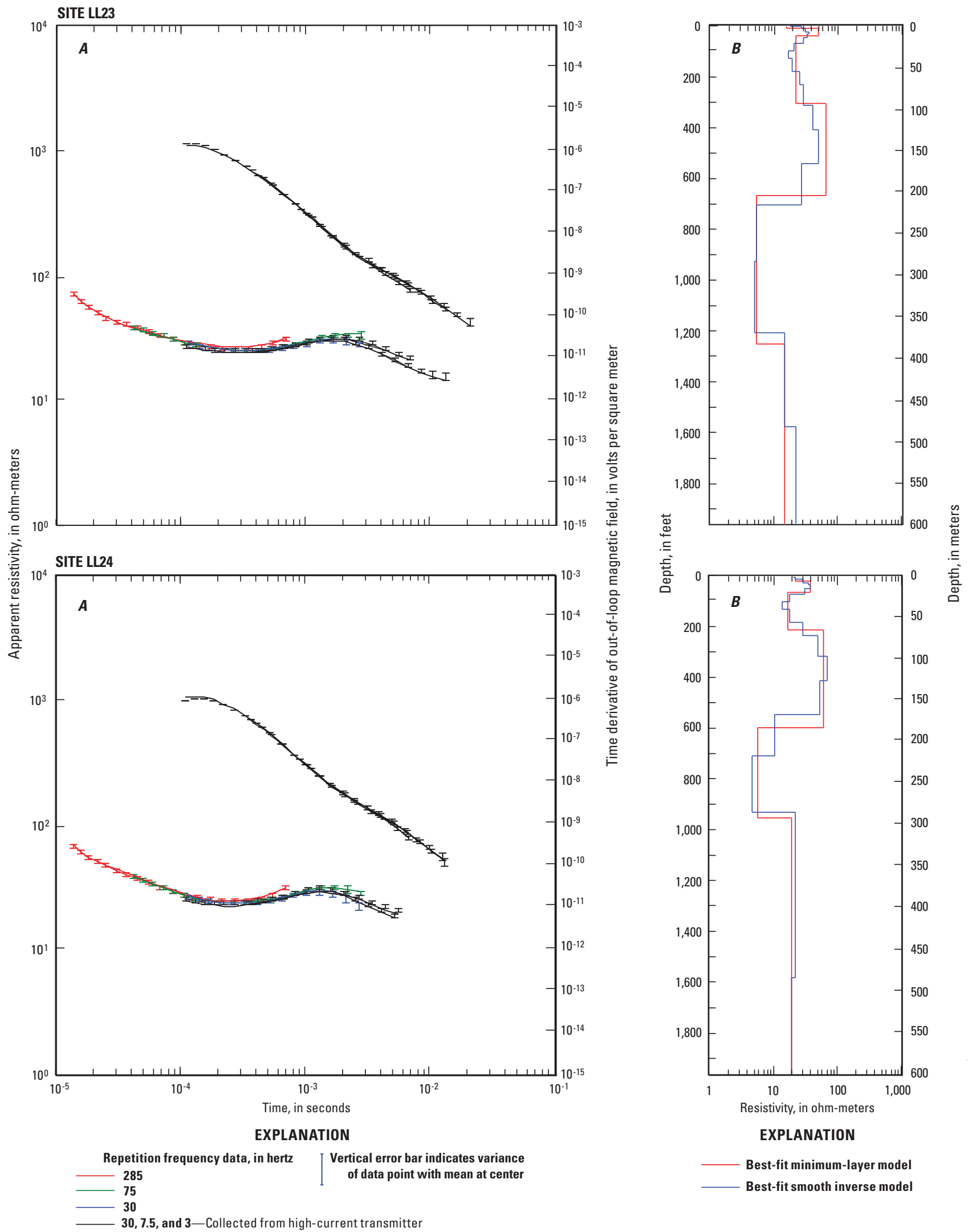

Figure 33. Relations between $A$, central-loop resistivity, out-of-loop vertical magnetic field (upper set of curves time-derivative, right axis), and time elapsed after primary current turnoff; and $B$, depth below land surface and subsurface resistivity modeled from time-domain electromagnetic sounding for sites LL23 and LL24. 

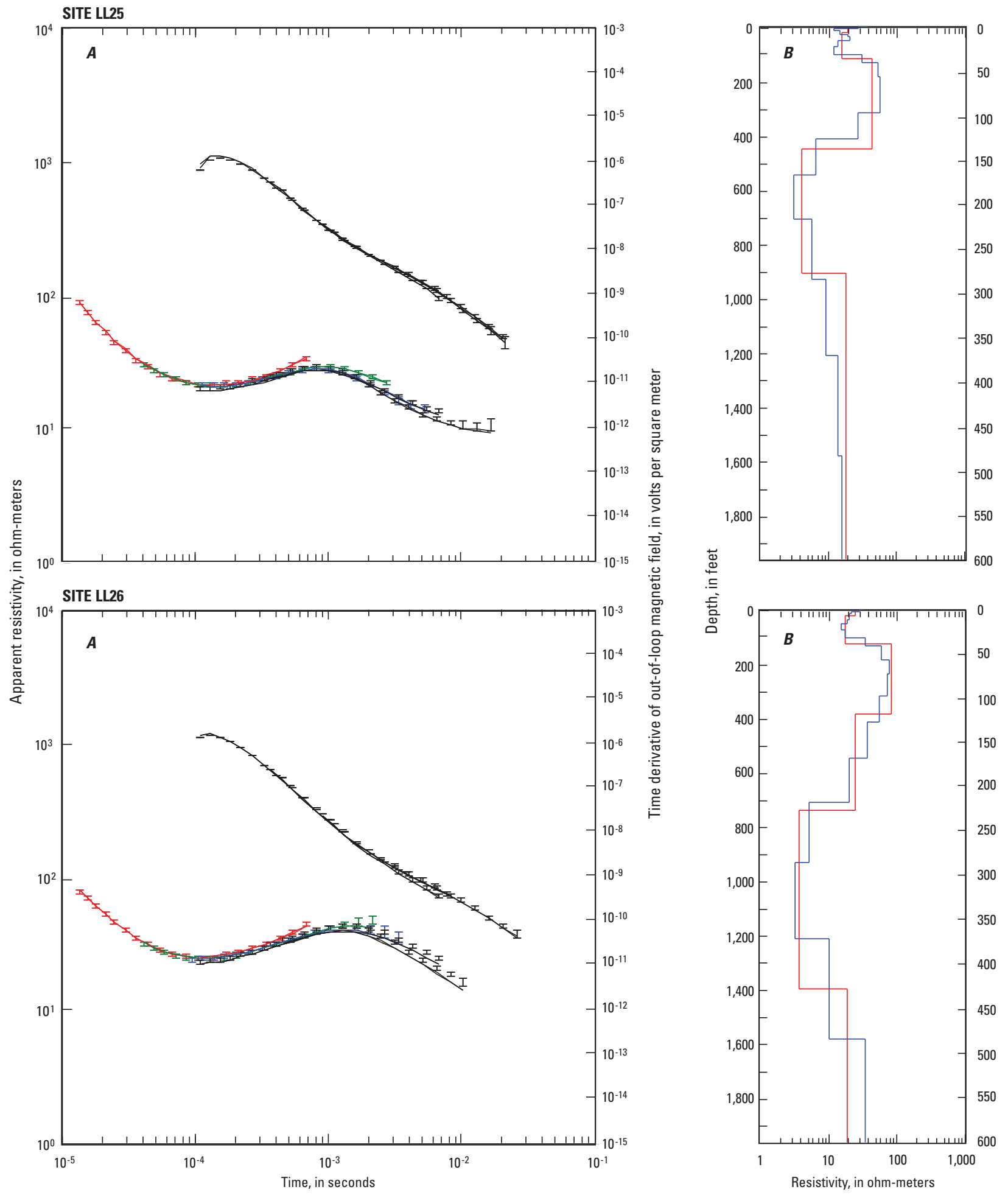

EXPLANATION

EXPLANATION

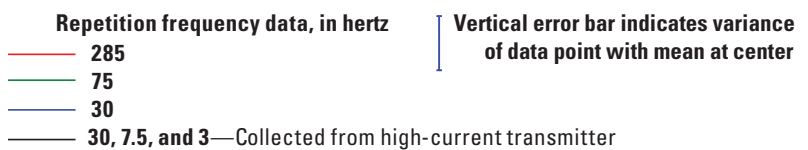

— Best-fit minimum-layer model Best-fit smooth inverse model

Figure 34. Relations between $A$, central-loop resistivity, out-of-loop vertical magnetic field (upper set of curves time-derivative, right axis), and time elapsed after primary current turnoff; and $B$, depth below land surface and subsurface resistivity modeled from time-domain electromagnetic sounding for sites LL25 and LL26. 

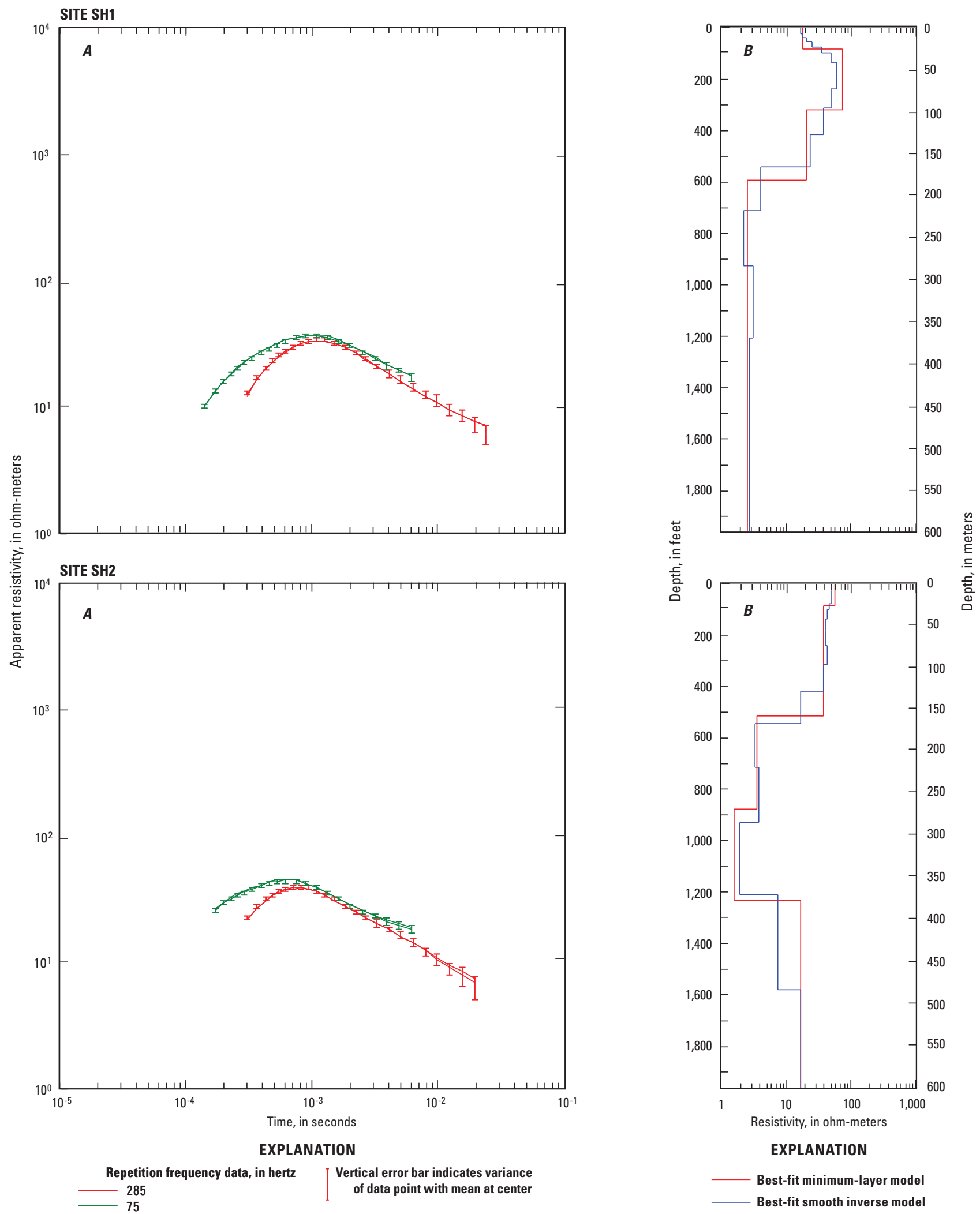

Figure 35. Relations between $A$, central-loop resistivity and time elapsed after primary current turnoff; and $B$, depth below land surface and subsurface resistivity modeled from time-domain electromagnetic sounding for sites SH1 and SH2. 

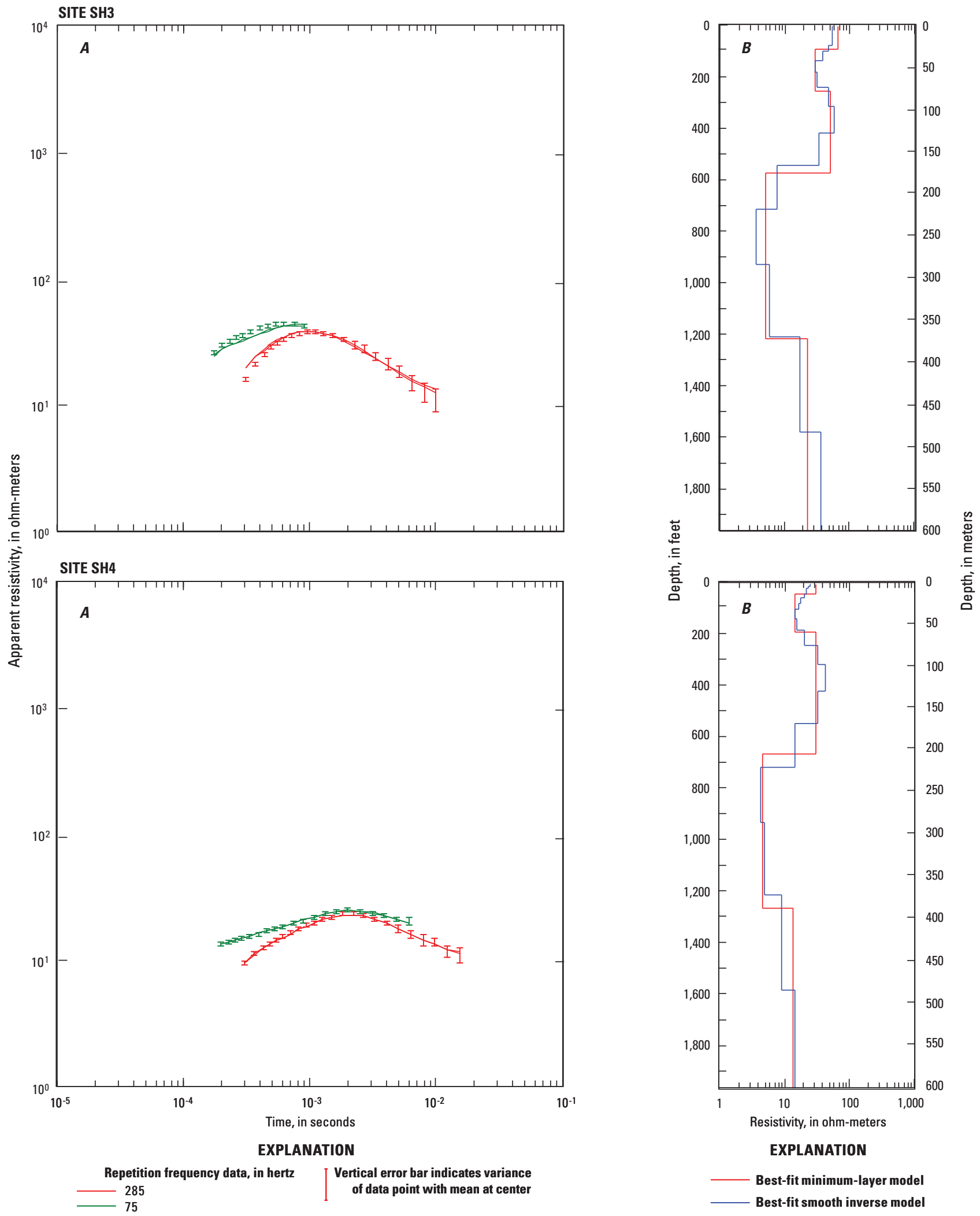

Figure 36. Relations between $A$, central-loop resistivity and time elapsed after primary current turnoff; and $B$, depth below land surface and subsurface resistivity modeled from time-domain electromagnetic sounding for sites $\mathrm{SH} 3$ and $\mathrm{SH} 4$. 

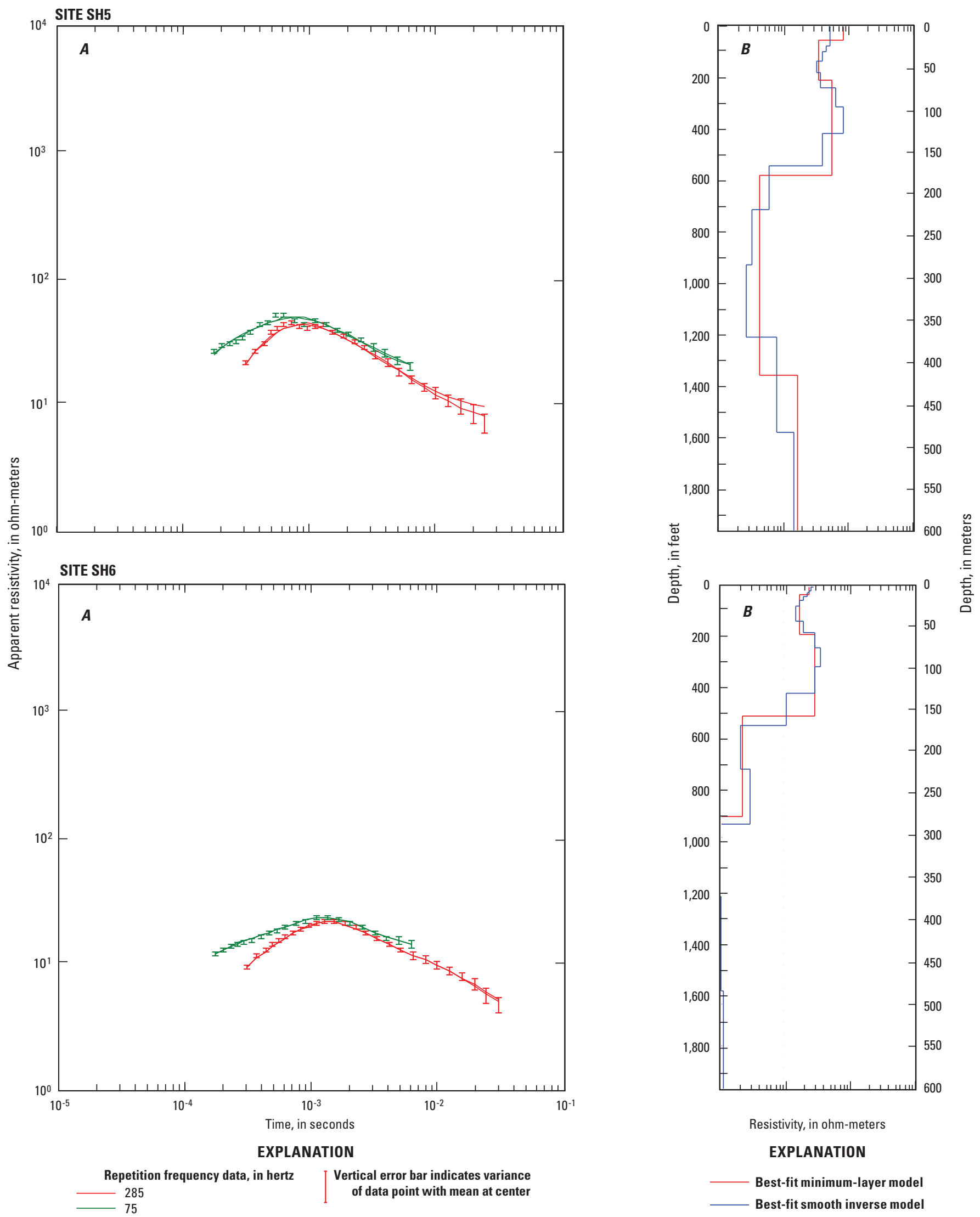

Figure 37. Relations between $A$, central-loop resistivity and time elapsed after primary current turnoff; and $B$, depth below land surface and subsurface resistivity modeled from time-domain electromagnetic sounding for sites SH5 and SH6. 
SITE SH7

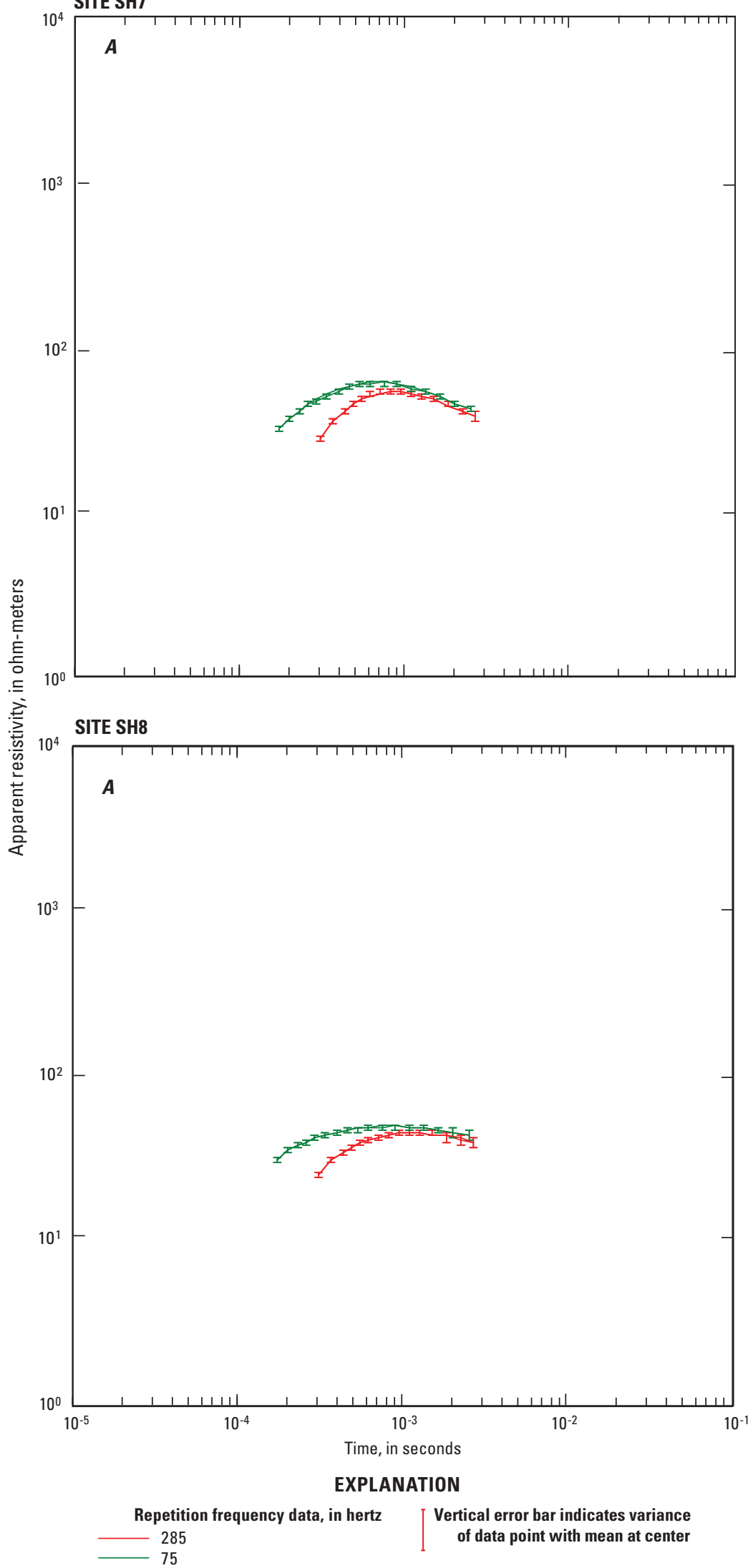

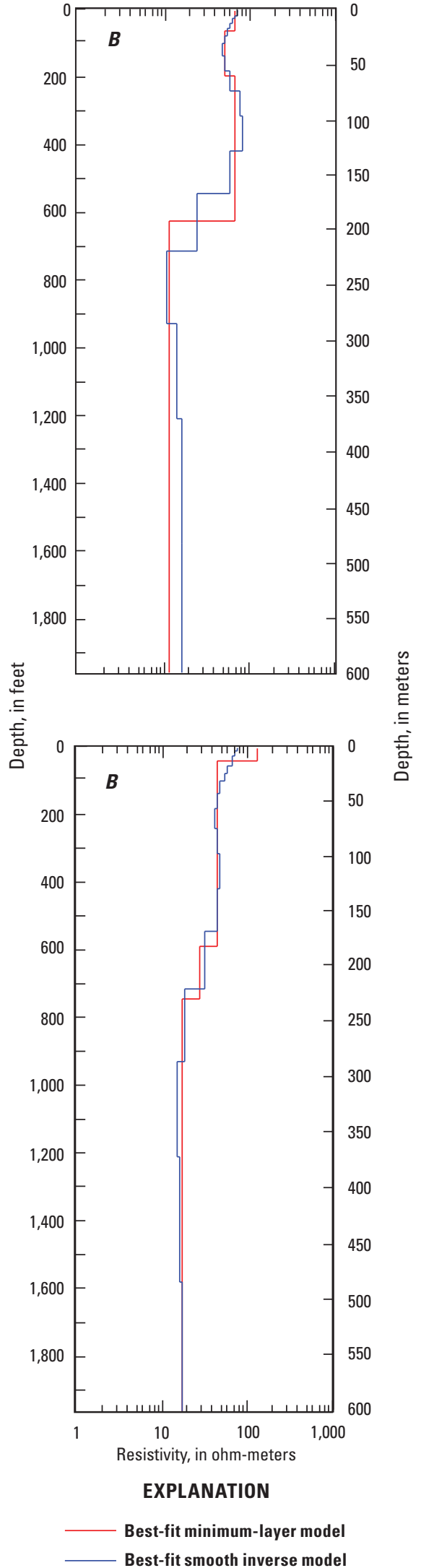

Figure 38. Relations between $A$, central-loop resistivity and time elapsed after primary current turnoff; and $B$, depth below land surface and subsurface resistivity modeled from time-domain electromagnetic sounding for sites $\mathrm{SH7}$ and SH8. 


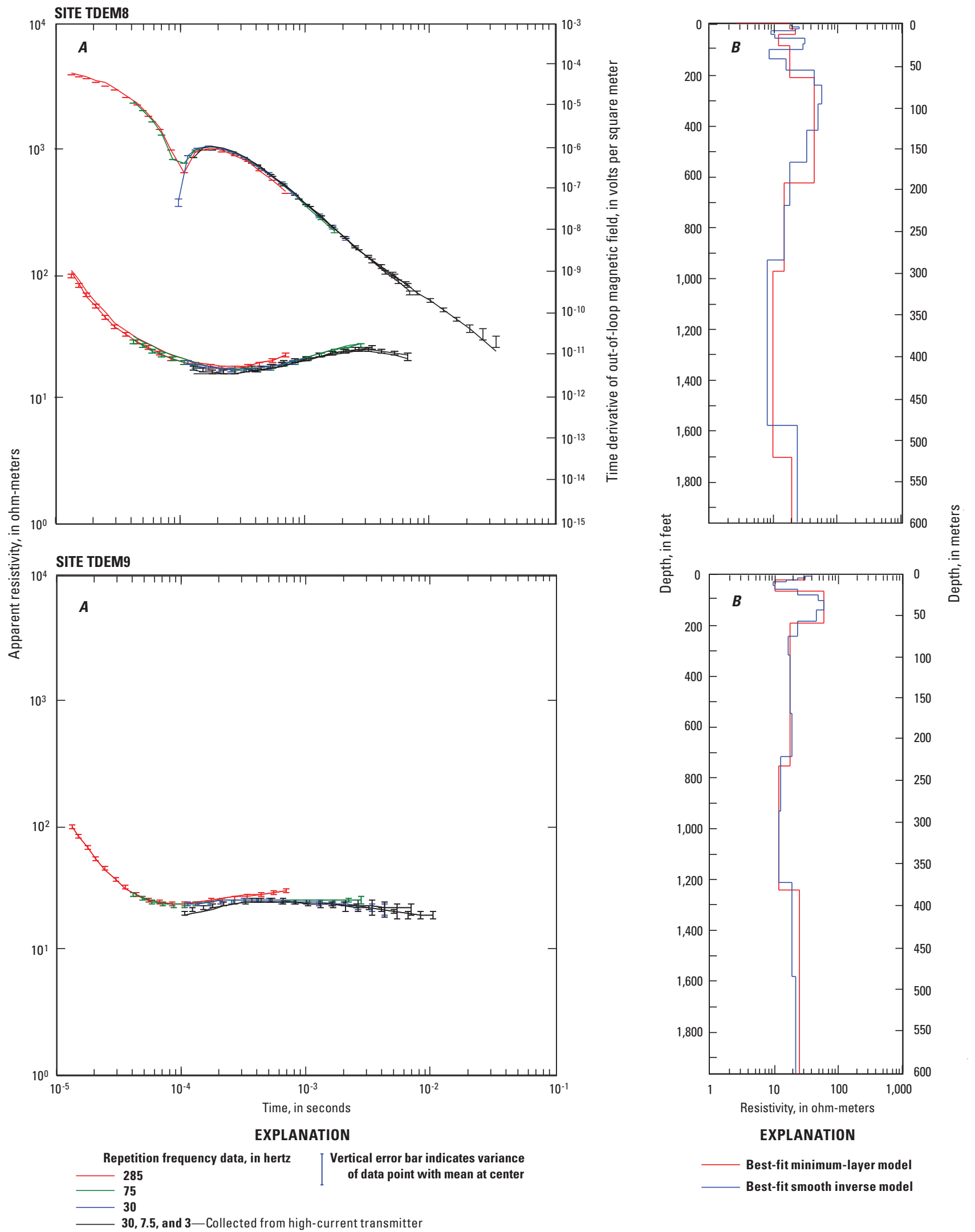

Figure 39. Relations between $A$, central-loop resistivity, out-of-loop vertical magnetic field (upper set of curves time-derivative, right axis for site TDEM8), and time elapsed after primary current turnoff; and $B$, depth below land surface and subsurface resistivity modeled from time-domain electromagnetic sounding for sites TDEM8 and TDEM9. 

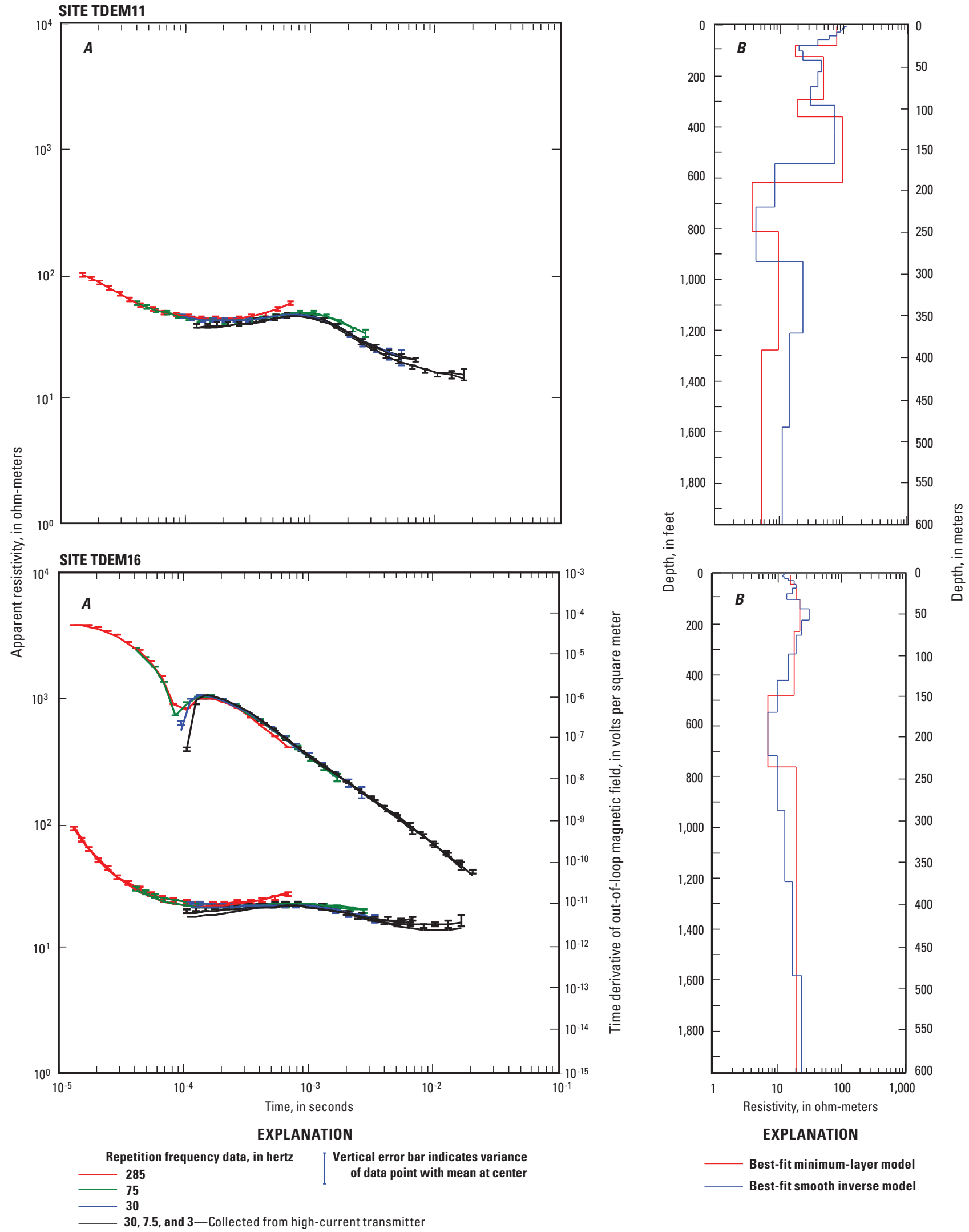

Figure 40. Relations between $A$, central-loop resistivity, out-of-loop vertical magnetic field (upper set of curves time-derivative, right axis for site TDEM16), and time elapsed after primary current turnoff; and $B$, depth below land surface and subsurface resistivity modeled from time-domain electromagnetic sounding for sites TDEM11 and TDEM16. 

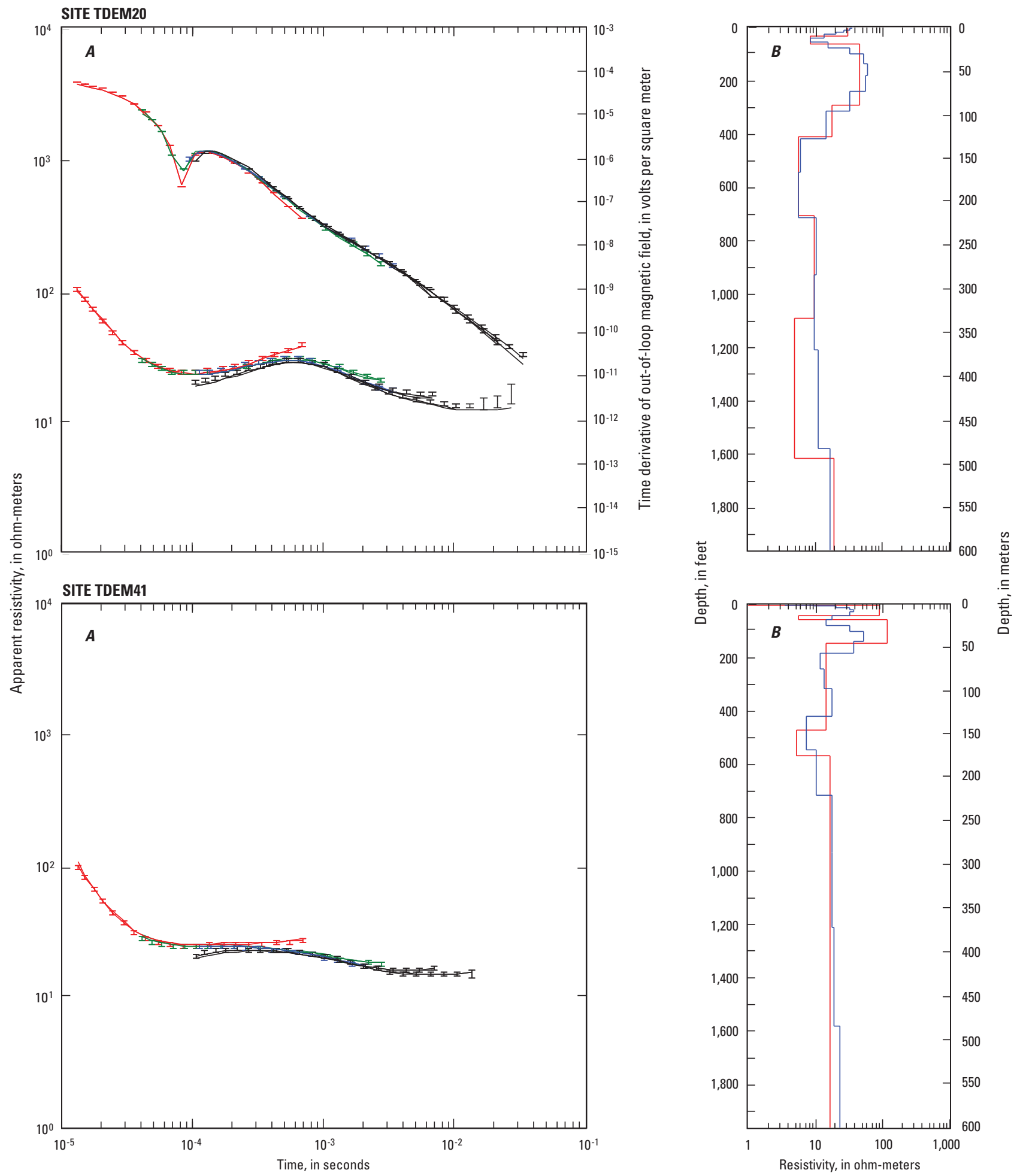

EXPLANATION

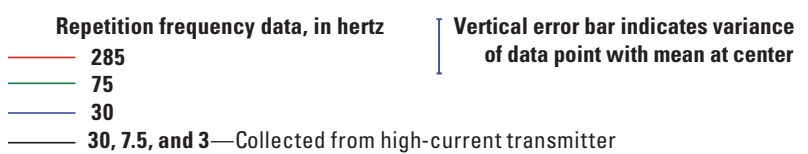

EXPLANATION

_ Best-fit minimum-layer model

__ Best-fit smooth inverse model

Figure 41. Relations between $A$, central-loop resistivity, out-of-loop vertical magnetic field (upper set of curves time-derivative, right axis for site TDEM20), and time elapsed after primary current turnoff; and $B$, depth below land surface and subsurface resistivity modeled from time-domain electromagnetic sounding for sites TDEM20 and TDEM41. 

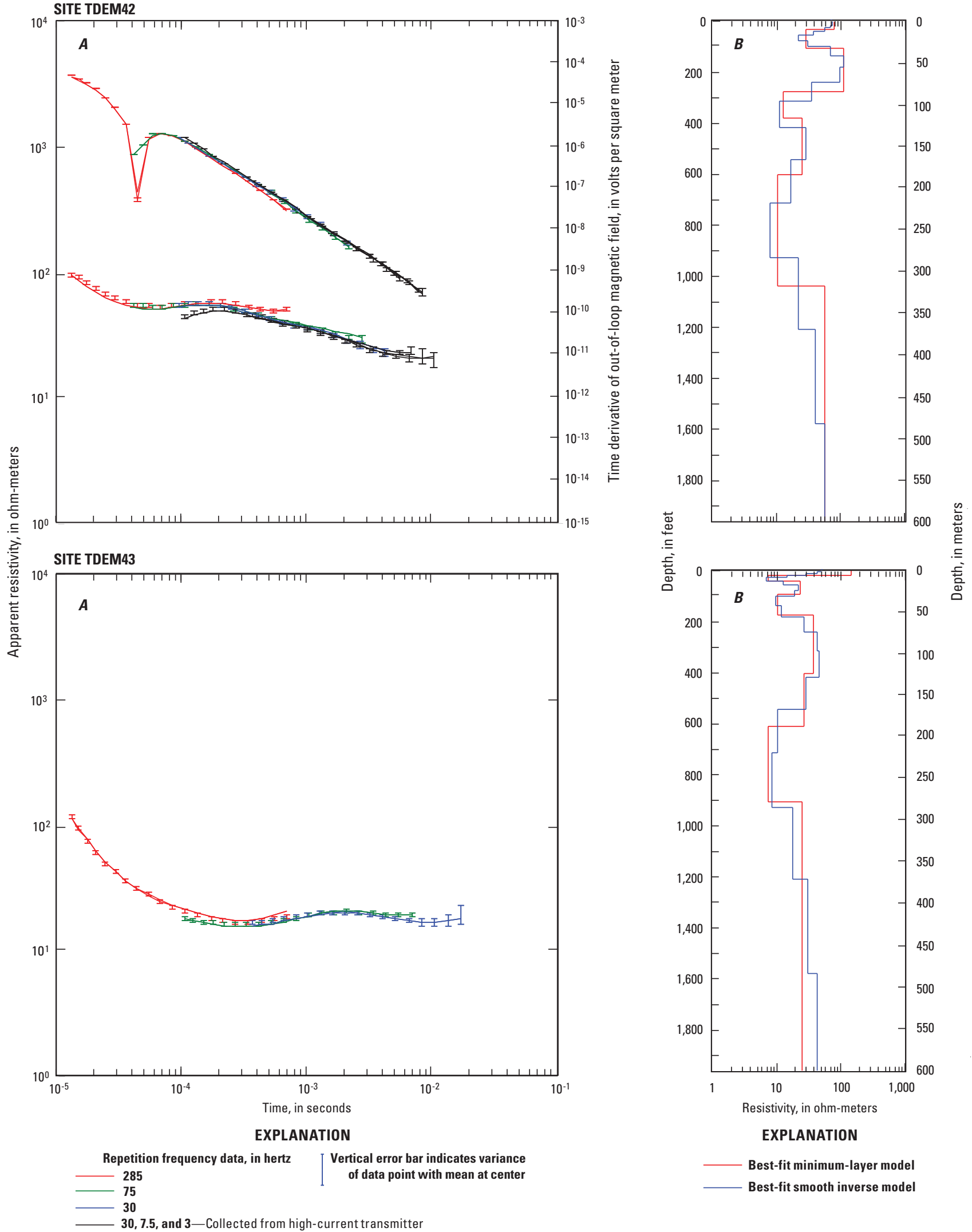

Figure 42. Relations between $A$, central-loop resistivity, out-of-loop vertical magnetic field (upper set of curves time-derivative, right axis for site TDEM42), and time elapsed after primary current turnoff; and $B$, depth below land surface and subsurface resistivity modeled from time-domain electromagnetic sounding for sites TDEM42 and TDEM43. 

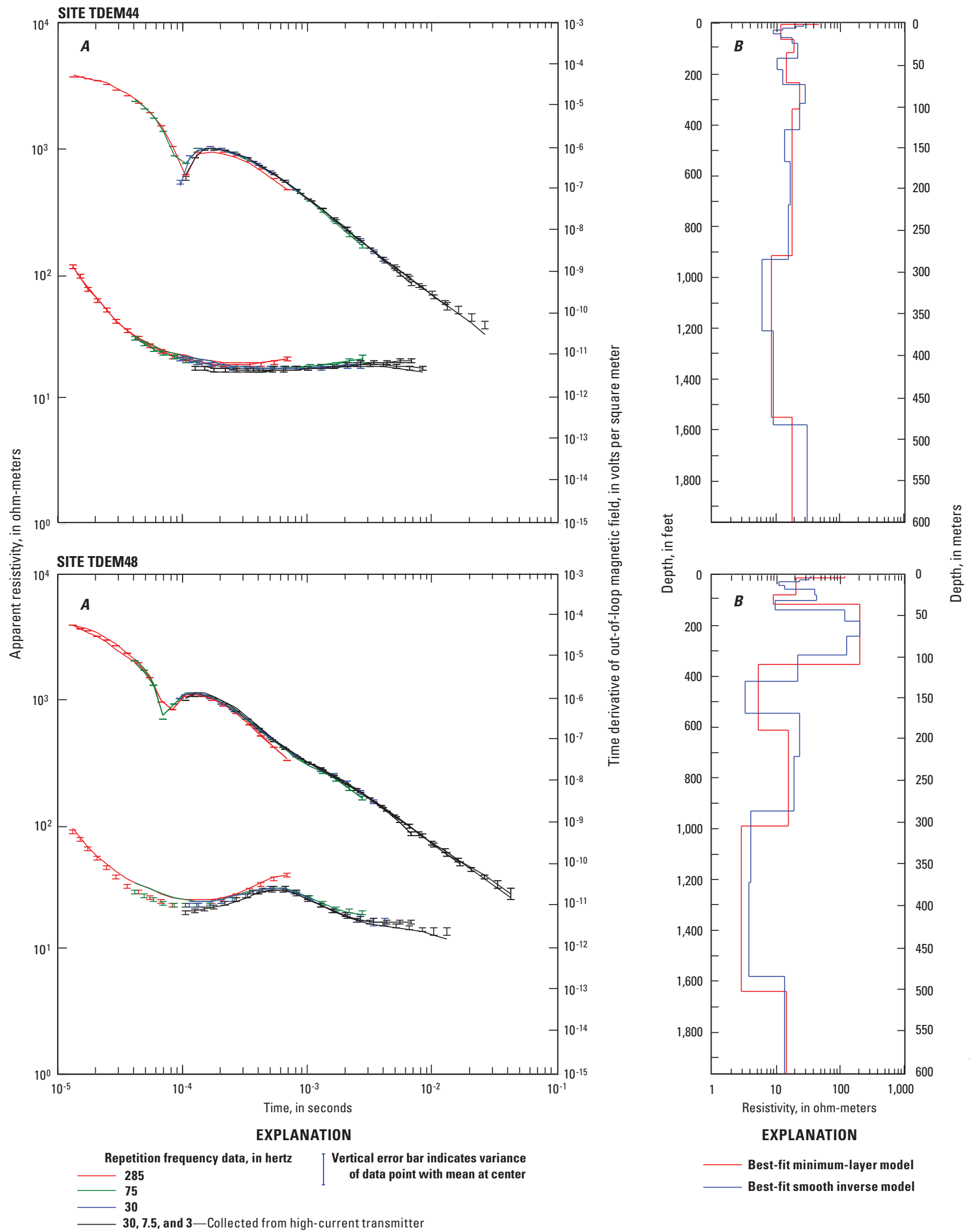

Figure 43. Relations between $A$, central-loop resistivity, out-of-loop vertical magnetic field (upper set of curves time-derivative, right axis), and time elapsed after primary current turnoff; and $B$, depth below land surface and subsurface resistivity modeled from time-domain electromagnetic sounding for sites TDEM44 and TDEM48. 
SITE TDEM49

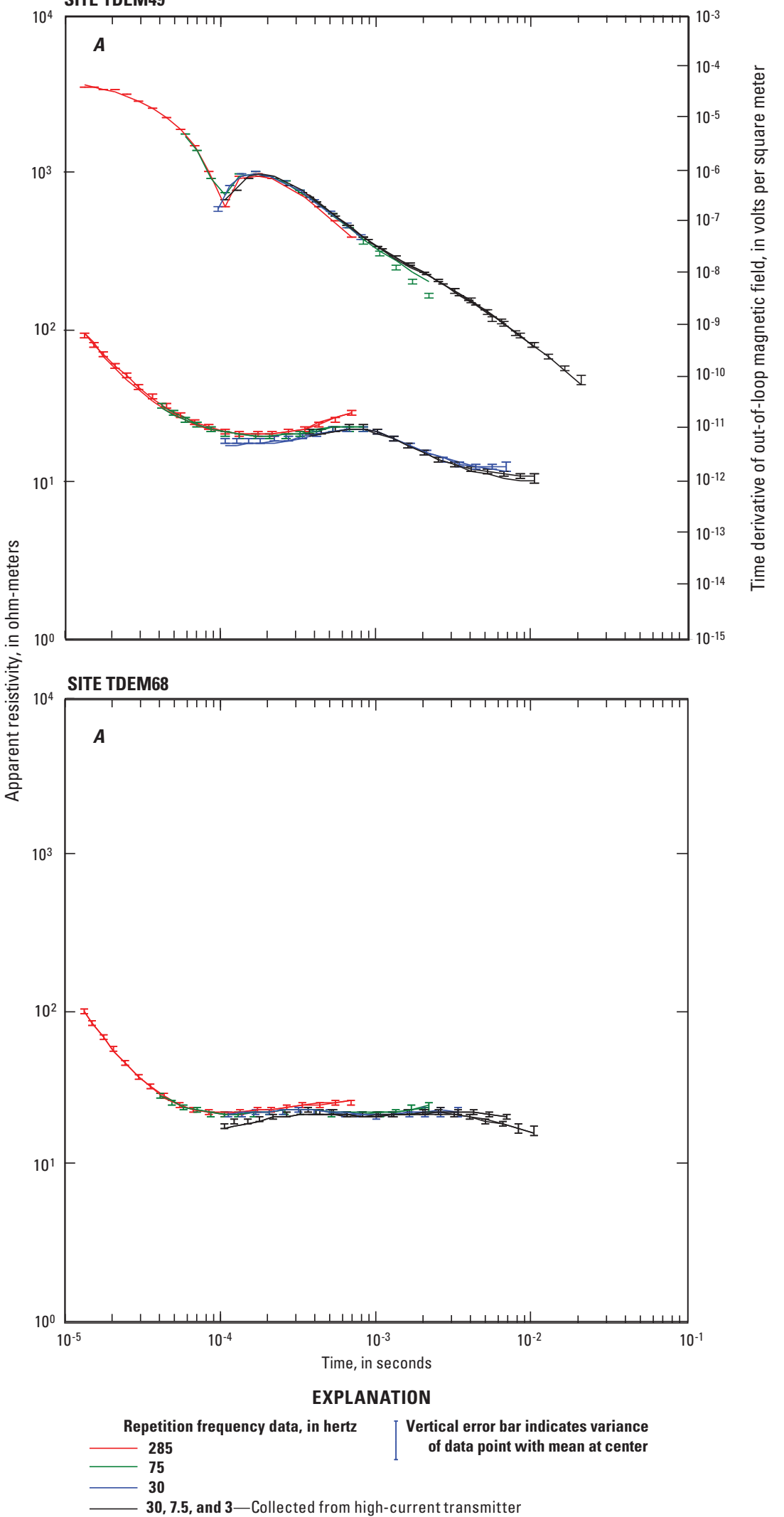

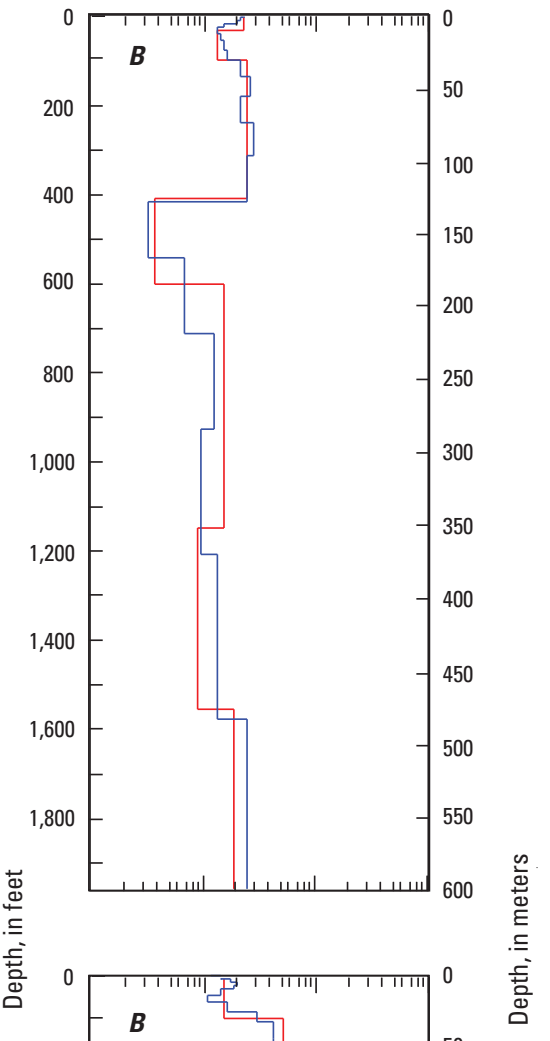

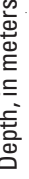
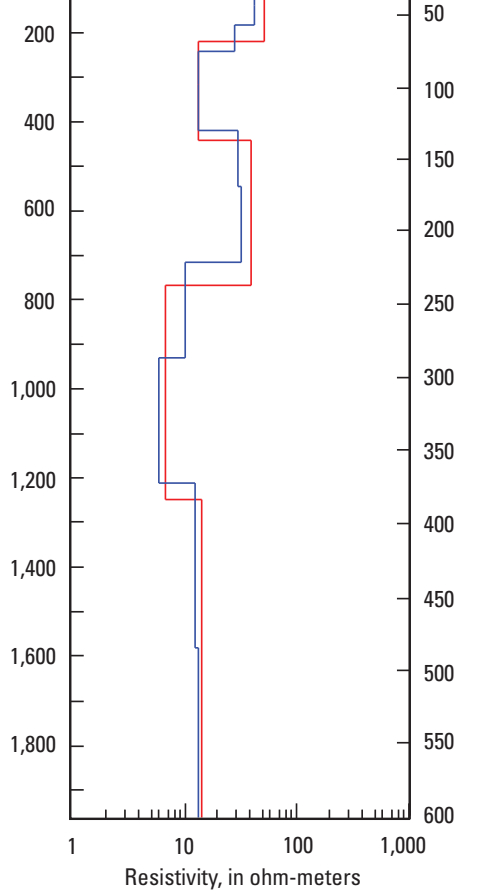

EXPLANATION

- Best-fit minimum-layer model Best-fit smooth inverse model

Figure 44. Relations between $A$, central-loop resistivity, out-of-loop vertical magnetic field (upper set of curves time-derivative, right axis for site TDEM49), and time elapsed after primary current turnoff; and $B$, depth below land surface and subsurface resistivity modeled from time-domain electromagnetic sounding for sites TDEM49 and TDEM68. 

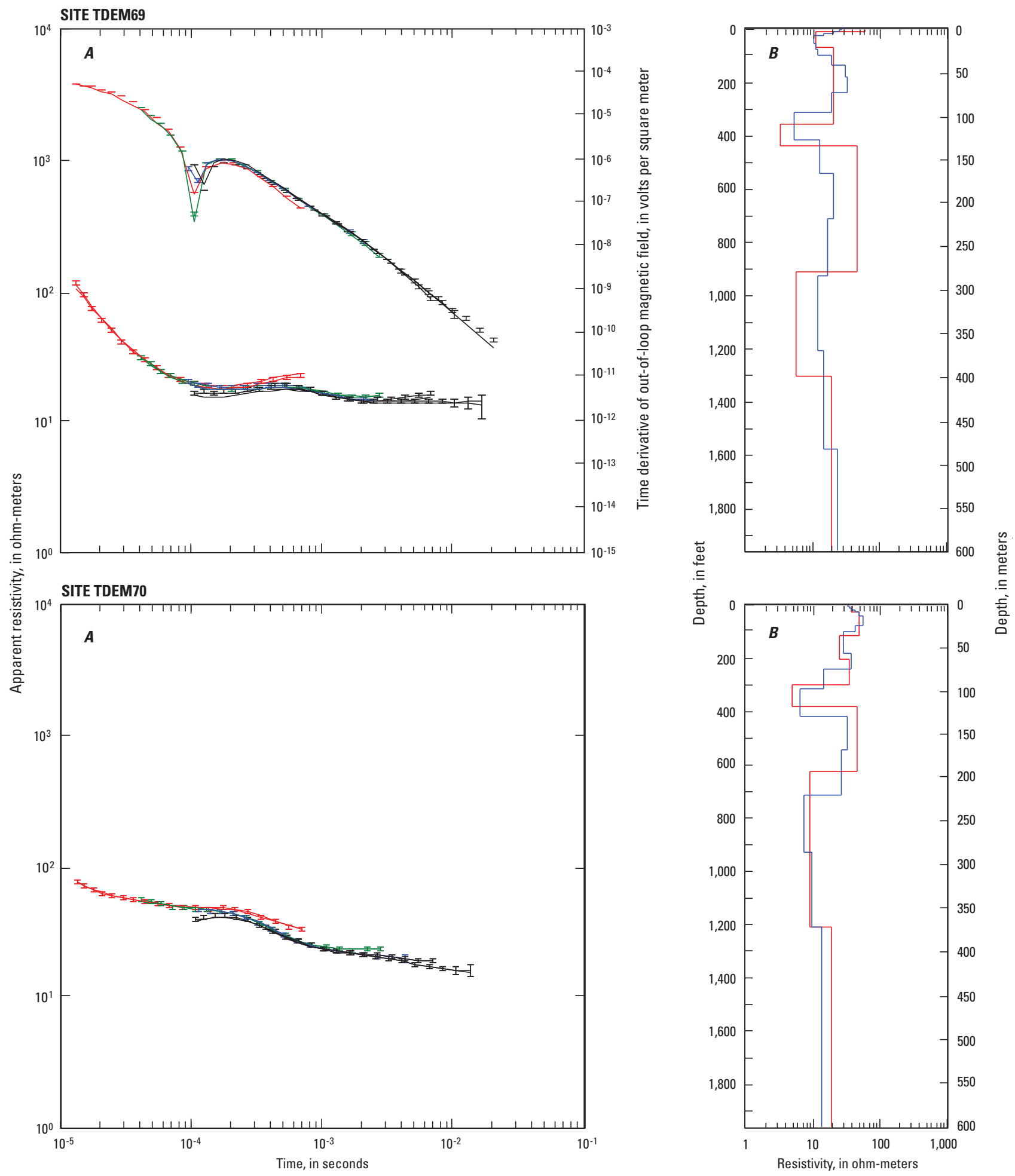

EXPLANATION

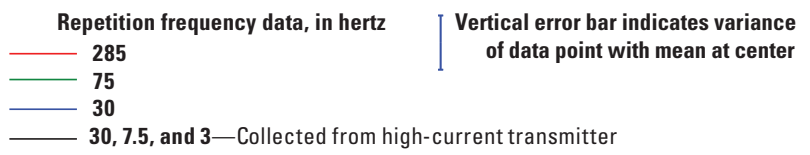

EXPLANATION

Best-fit minimum-layer model Best-fit smooth inverse model

Figure 45. Relations between $A$, central-loop resistivity, out-of-loop vertical magnetic field (upper set of curves time-derivative, right axis for site TDEM69), and time elapsed after primary current turnoff; and $B$, depth below land surface and subsurface resistivity modeled from time-domain electromagnetic sounding for sites TDEM69 and TDEM70. 

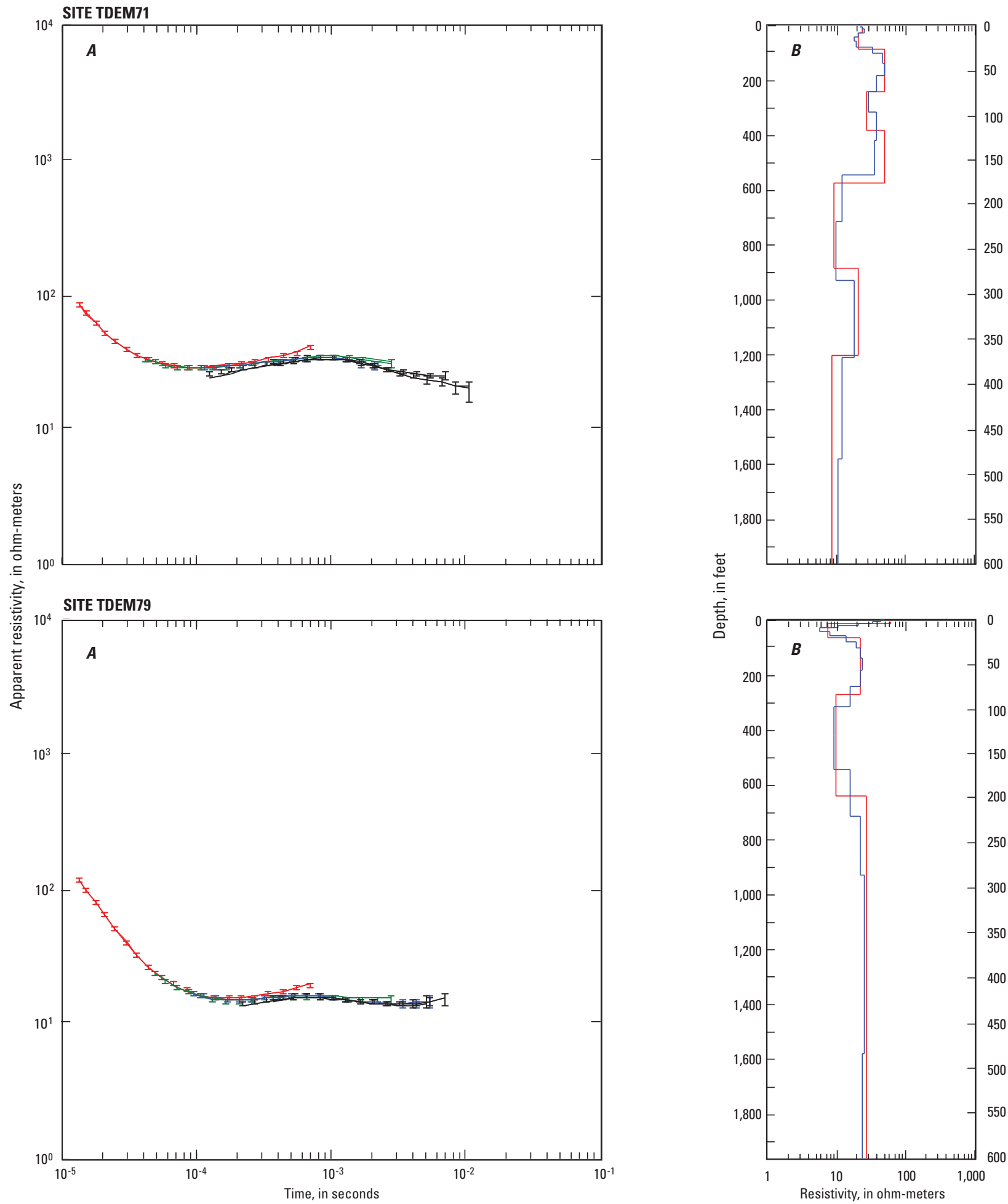

EXPLANATION

EXPLANATION

Repetition frequency data, in hertz [ Vertical error bar indicates variance 285

of data point with mean at center

Best-fit minimum-layer model Best-fit smooth inverse model

30, 7.5, and 3-Collected from high-current transmitter

Figure 46. Relations between $A$, central-loop resistivity and time elapsed after primary current turnoff; and $B$, depth below land surface and subsurface resistivity modeled from time-domain electromagnetic sounding for sites TDEM71 and TDEM79. 

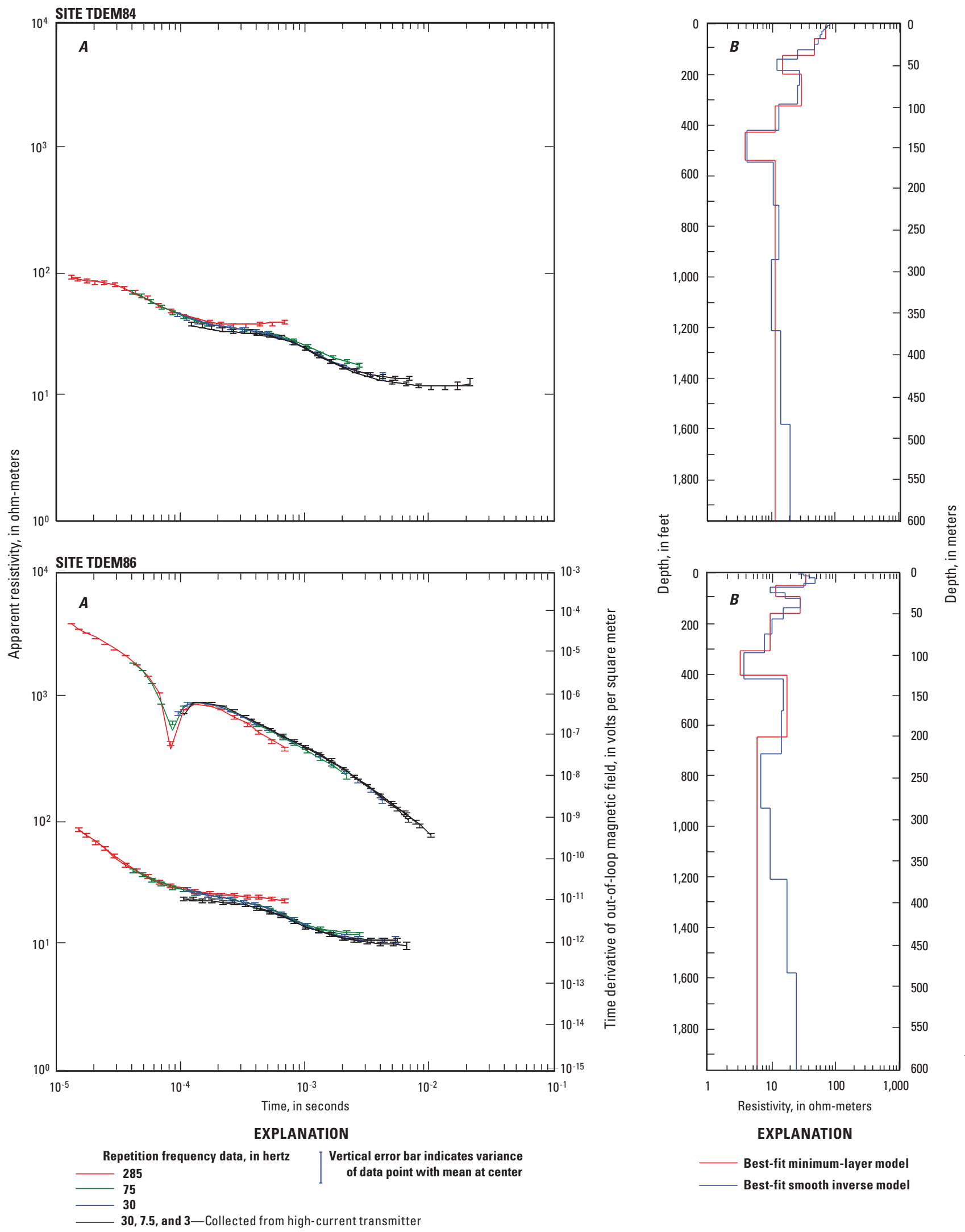

Figure 47. Relations between $A$, central-loop resistivity, out-of-loop vertical magnetic field (upper set of curves time-derivative, right axis for site TDEM86), and time elapsed after primary current turnoff; and $B$, depth below land surface and subsurface resistivity modeled from time-domain electromagnetic sounding for sites TDEM84 and TDEM86. 

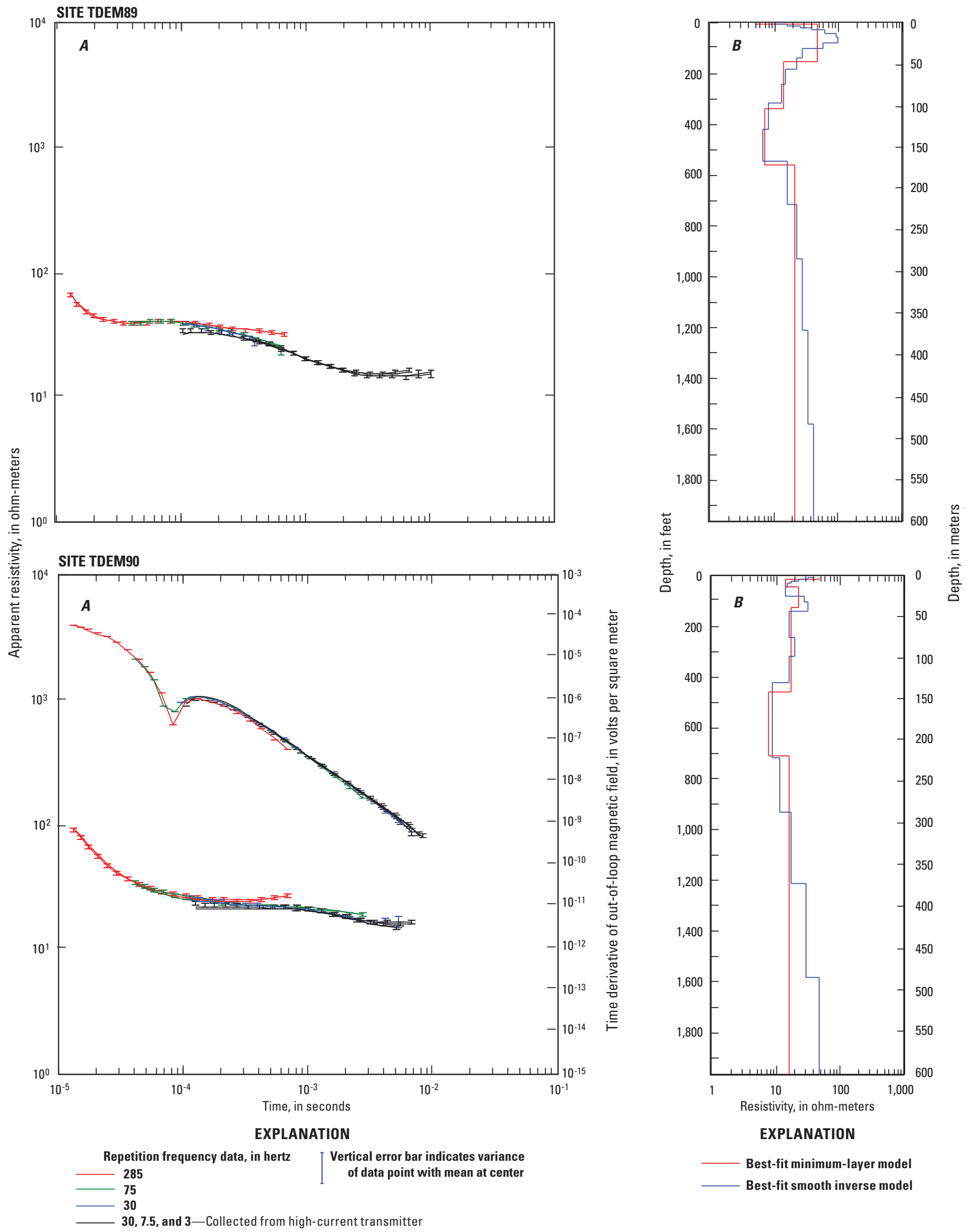

Figure 48. Relations between $A$, central-loop resistivity, out-of-loop vertical magnetic field (upper set of curves time-derivative, right axis for site TDEM90), and time elapsed after primary current turnoff; and $B$, depth below land surface and subsurface resistivity modeled from time-domain electromagnetic sounding for sites TDEM89 and TDEM90. 

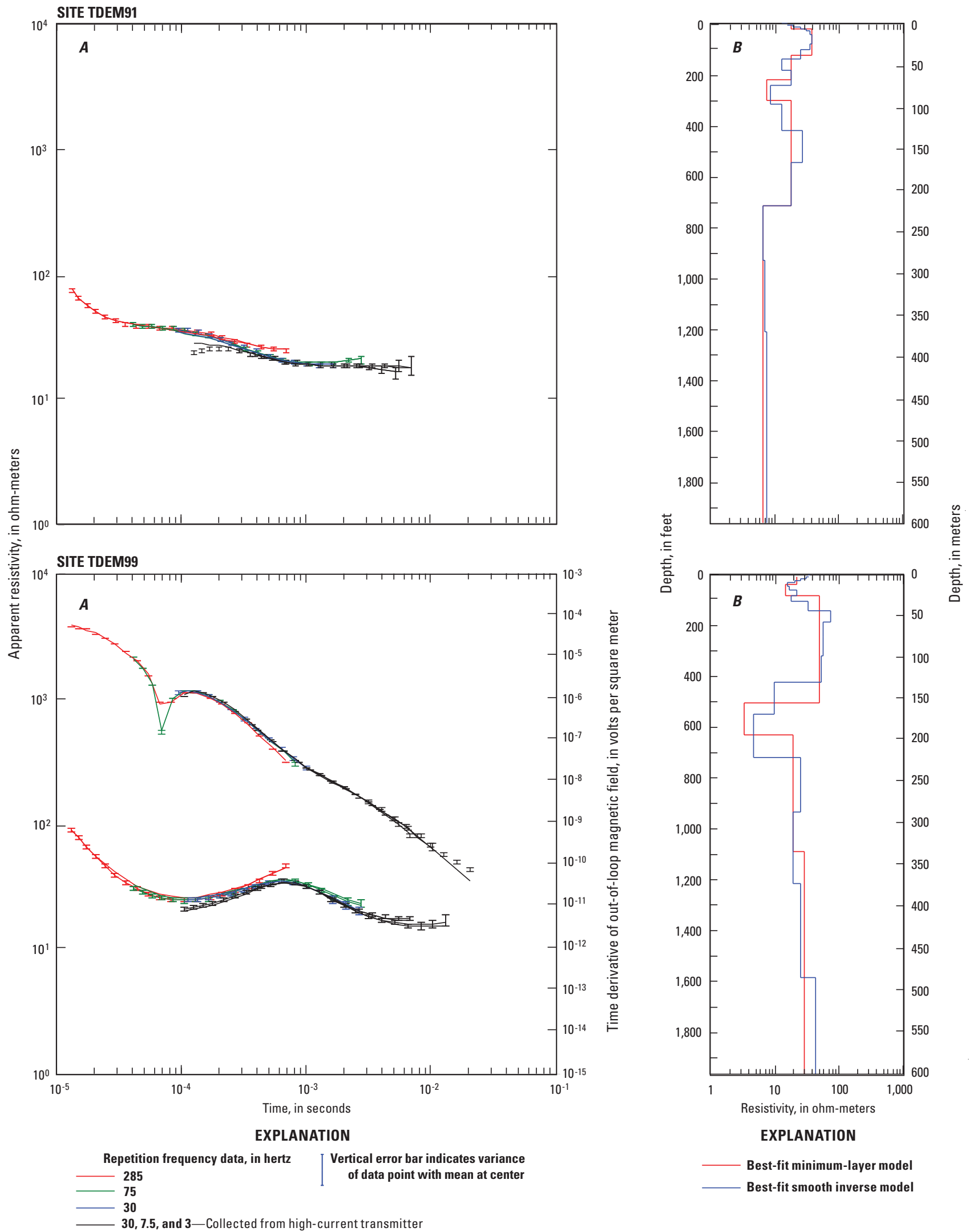

Figure 49. Relations between $A$, central-loop resistivity, out-of-loop vertical magnetic field (upper set of curves time-derivative, right axis for site TDEM99), and time elapsed after primary current turnoff; and $B$, depth below land surface and subsurface resistivity modeled from time-domain electromagnetic sounding for sites TDEM91 and TDEM99. 

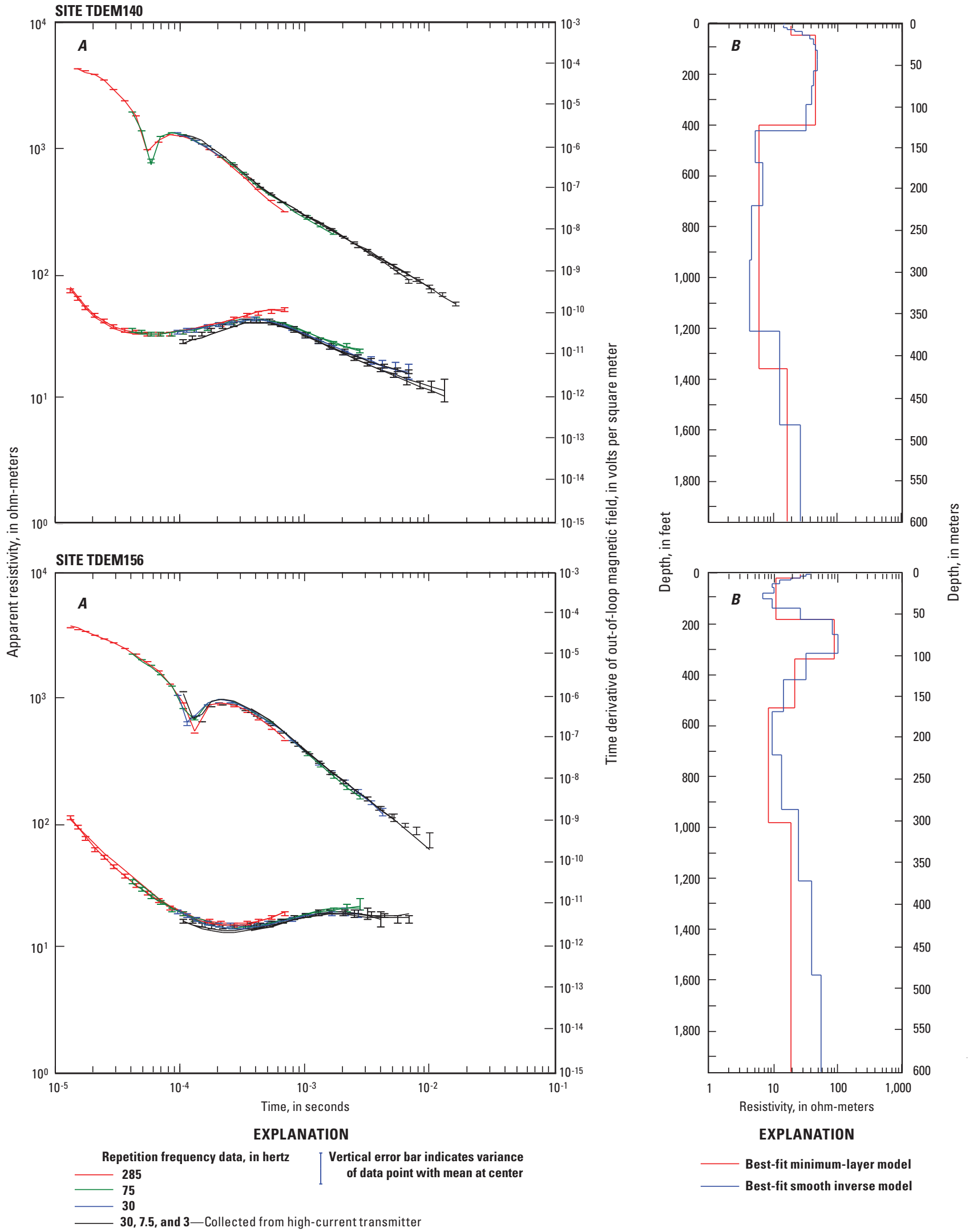

Figure 50. Relations between $A$, central-loop resistivity, out-of-loop vertical magnetic field (upper set of curves time-derivative, right axis), and time elapsed after primary current turnoff; and $B$, depth below land surface and subsurface resistivity modeled from time-domain electromagnetic sounding for sites TDEM140 and TDEM156. 


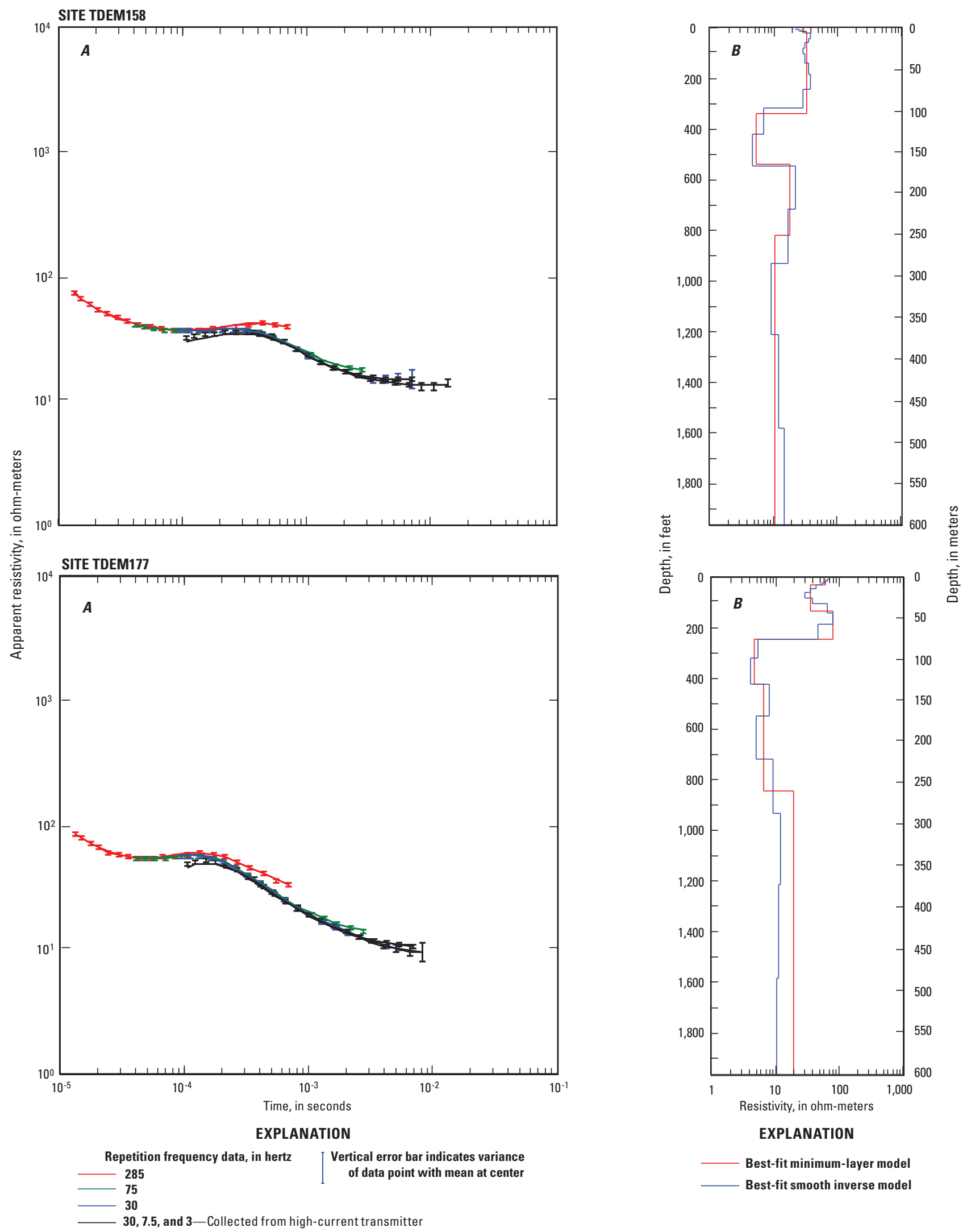

Figure 51. Relations between $A$, central-loop resistivity and time elapsed after primary current turnoff; and $B$, depth below land surface and subsurface resistivity modeled from time-domain electromagnetic sounding for sites TDEM158 and TDEM177. 

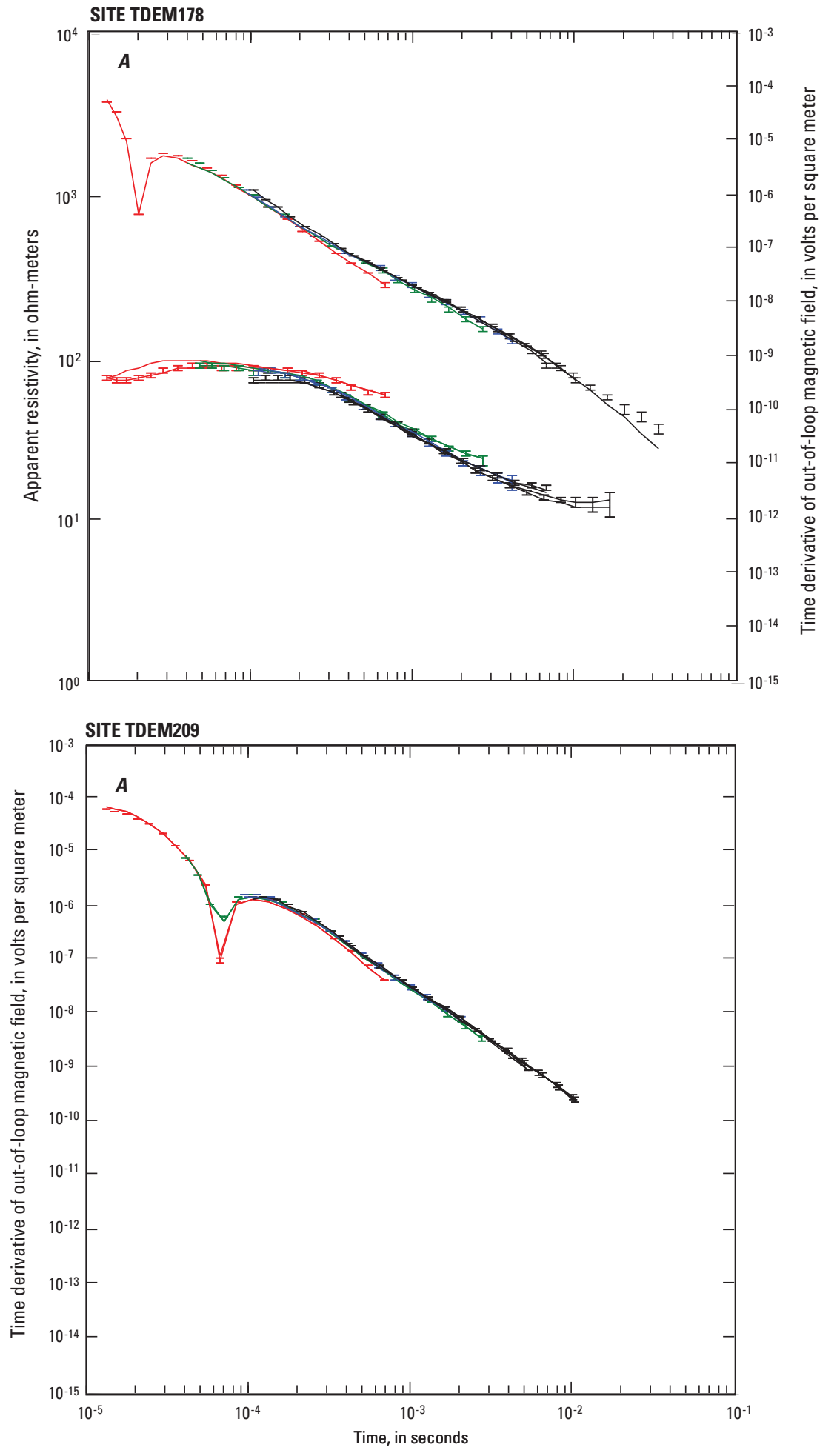

EXPLANATION
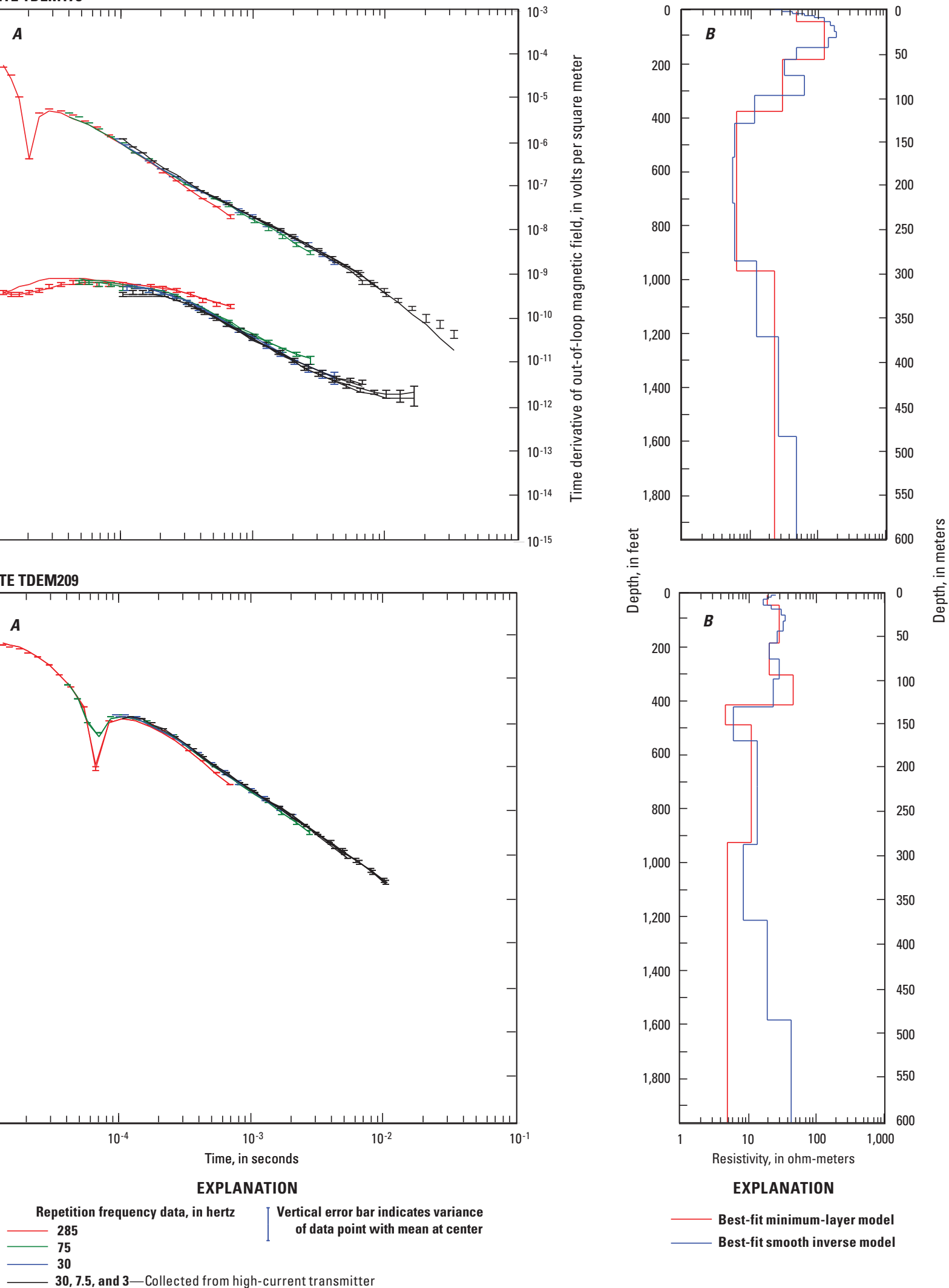

EXPLANATION

Best-fit minimum-layer model

Best-fit smooth inverse model

Figure 52. Relations between $A$, central-loop resistivity, out-of-loop vertical magnetic field (upper set of curves time-derivative, right axis), and time elapsed after primary current turnoff; and $B$, depth below land surface and subsurface resistivity modeled from time-domain electromagnetic sounding for site TDEM178. (Site TDEM209 only includes out-of-loop vertical magnetic field data in left panel.) 

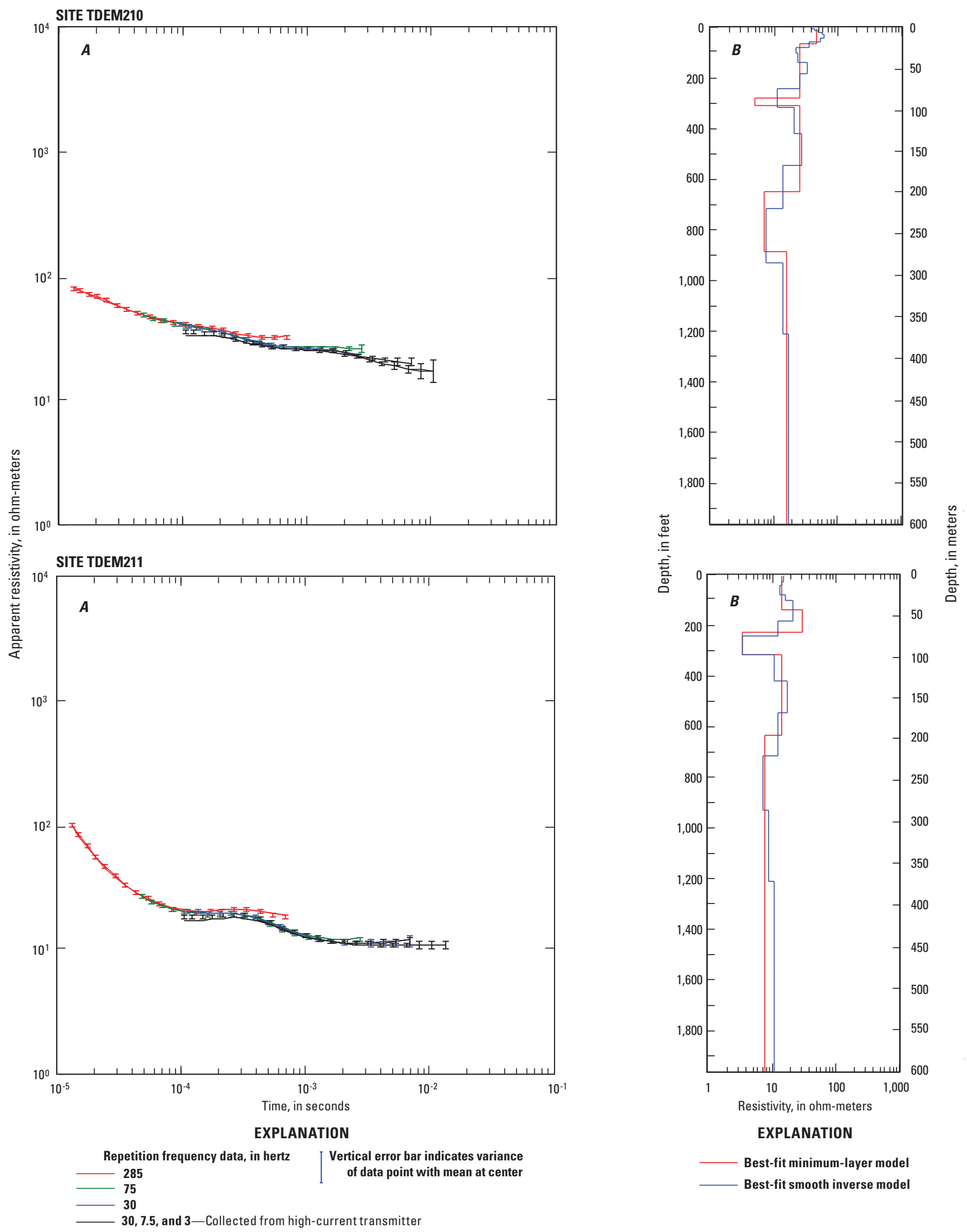

Figure 53. Relations between $A$, central-loop resistivity and time elapsed after primary current turnoff; and $B$, depth below land surface and subsurface resistivity modeled from time-domain electromagnetic sounding for sites TDEM210 and TDEM211. 
SITE TDEM212

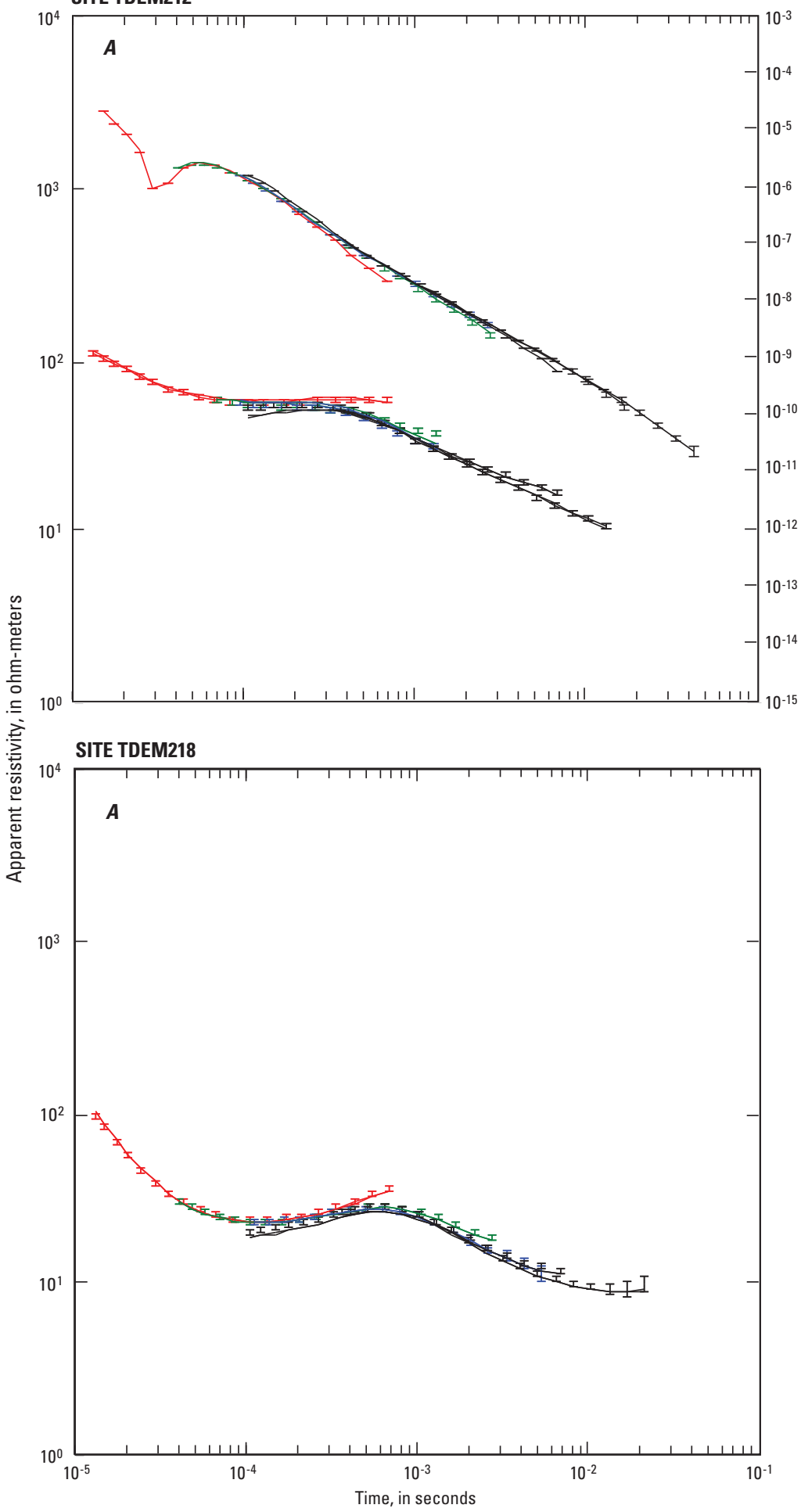

EXPLANATION

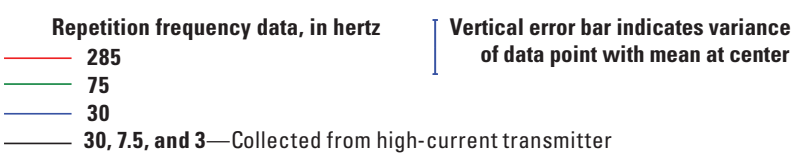

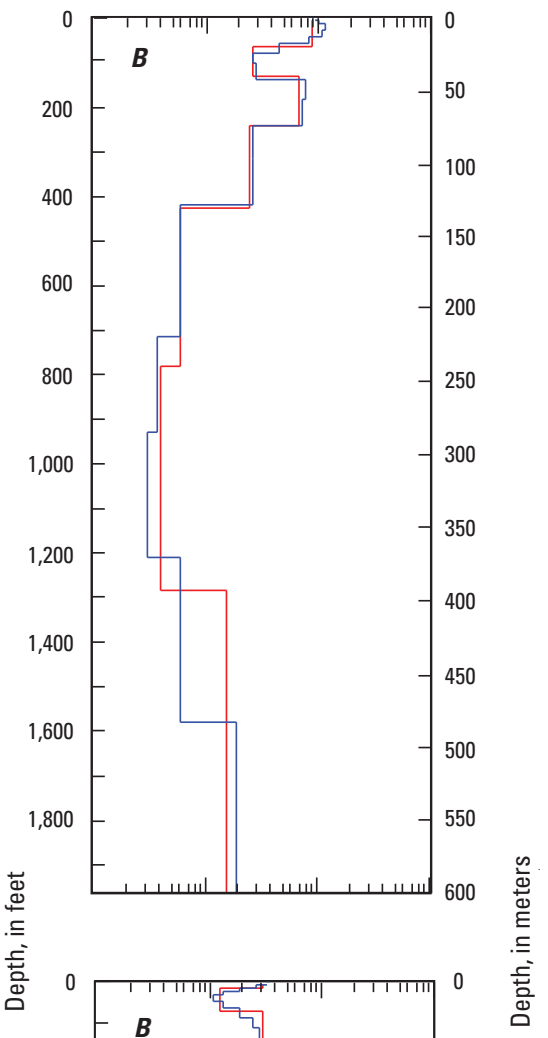

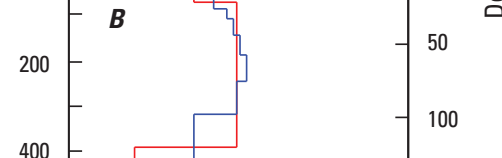

150

200

250

300

350

400

450

500

550

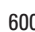

Resistivity, in ohm-meters

EXPLANATION

— Best-fit minimum-layer model Best-fit smooth inverse model

Figure 54. Relations between $A$, central-loop resistivity, out-of-loop vertical magnetic field (upper set of curves time-derivative, right axis for site TDEM212), and time elapsed after primary current turnoff; and $B$, depth below land surface and subsurface resistivity modeled from time-domain electromagnetic sounding for sites TDEM212 and TDEM218. 
SITE TDEM223

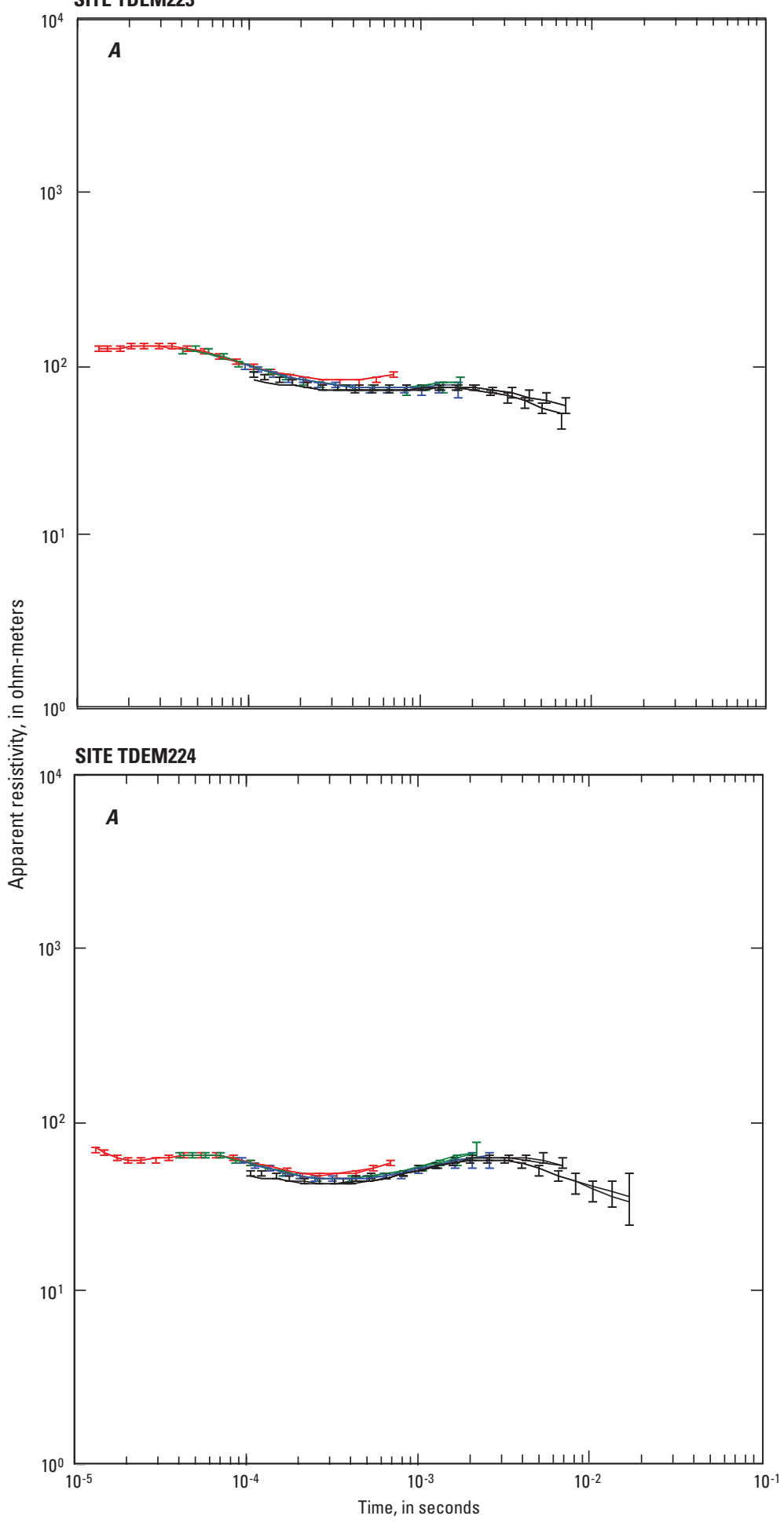

EXPLANATION

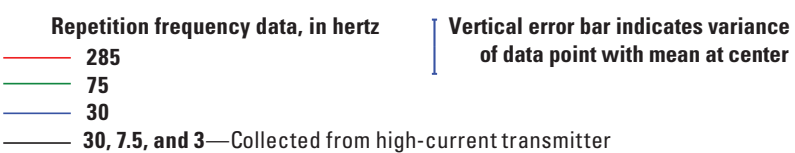

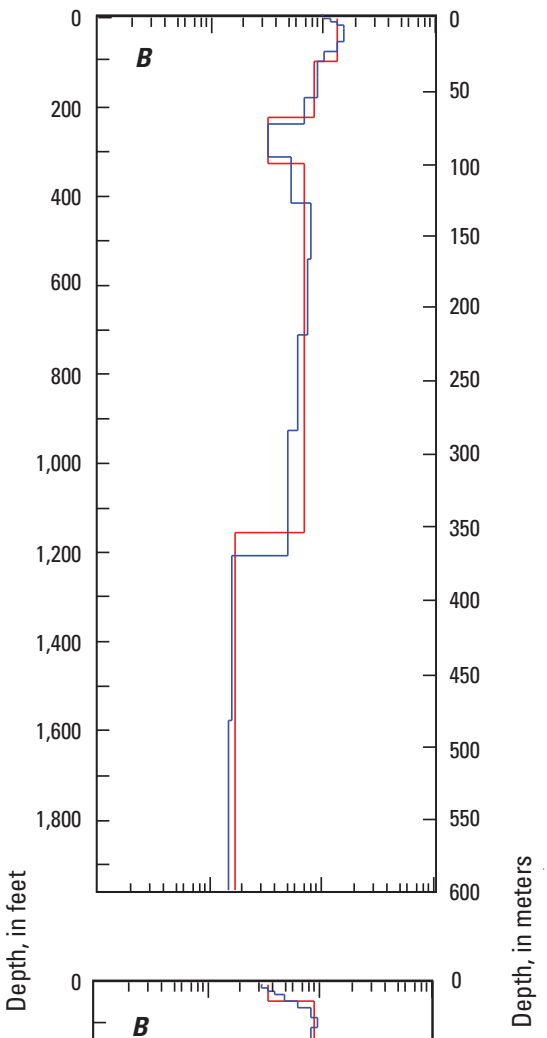
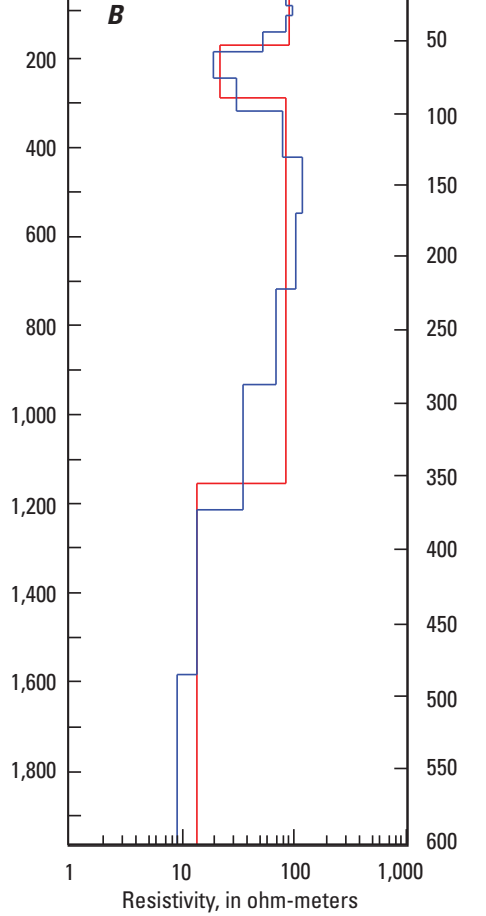

EXPLANATION

Best-fit minimum-layer model Best-fit smooth inverse model

Figure 55. Relations between $A$, central-loop resistivity and time elapsed after primary current turnoff; and $B$, depth below land surface and subsurface resistivity modeled from time-domain electromagnetic sounding for sites TDEM223 and TDEM224. 

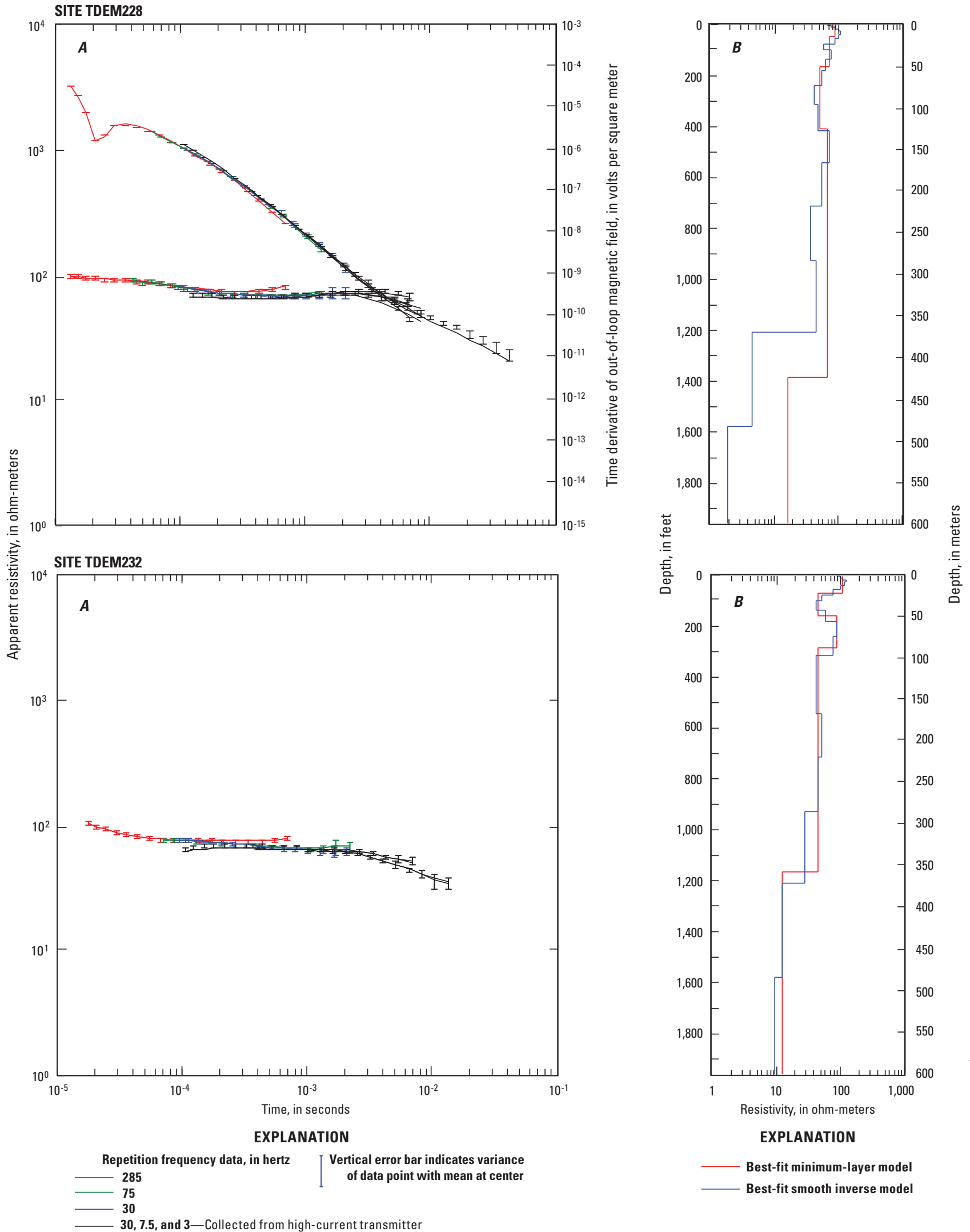

Figure 56. Relations between $A$, central-loop resistivity, out-of-loop vertical magnetic field (upper set of curves time-derivative, right axis for site TDEM228), and time elapsed after primary current turnoff; and $B$, depth below land surface and subsurface resistivity modeled from time-domain electromagnetic sounding for sites TDEM228 and TDEM232. 

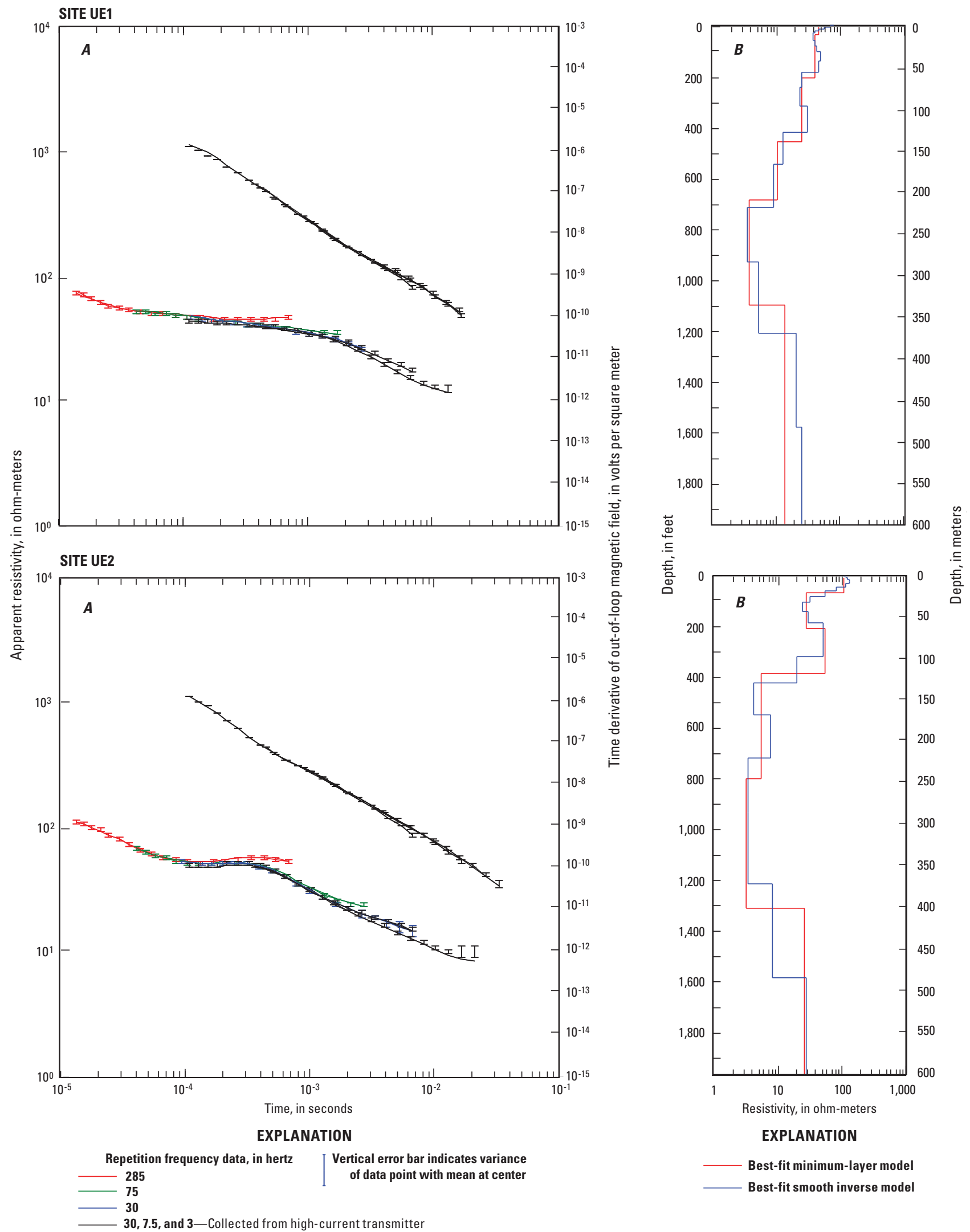

Figure 57. Relations between $A$, central-loop resistivity, out-of-loop vertical magnetic field (upper set of curves time-derivative, right axis), and time elapsed after primary current turnoff; and $B$, depth below land surface and subsurface resistivity modeled from time-domain electromagnetic sounding for sites UE1 and UE2. 

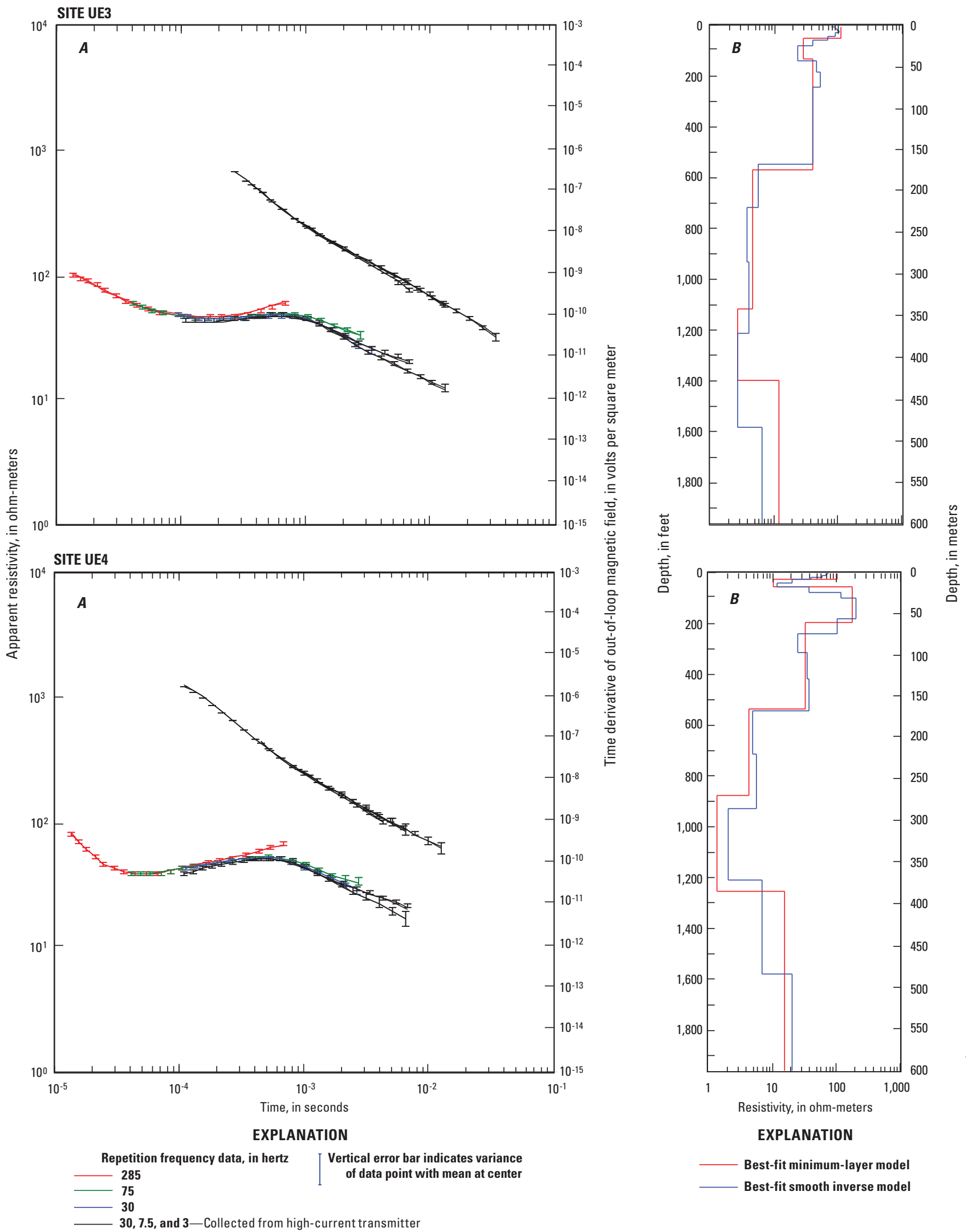

Figure 58. Relations between $A$, central-loop resistivity, out-of-loop vertical magnetic field (upper set of curves time-derivative, right axis), and time elapsed after primary current turnoff; and $B$, depth below land surface and subsurface resistivity modeled from time-domain electromagnetic sounding for sites UE3 and UE4. 

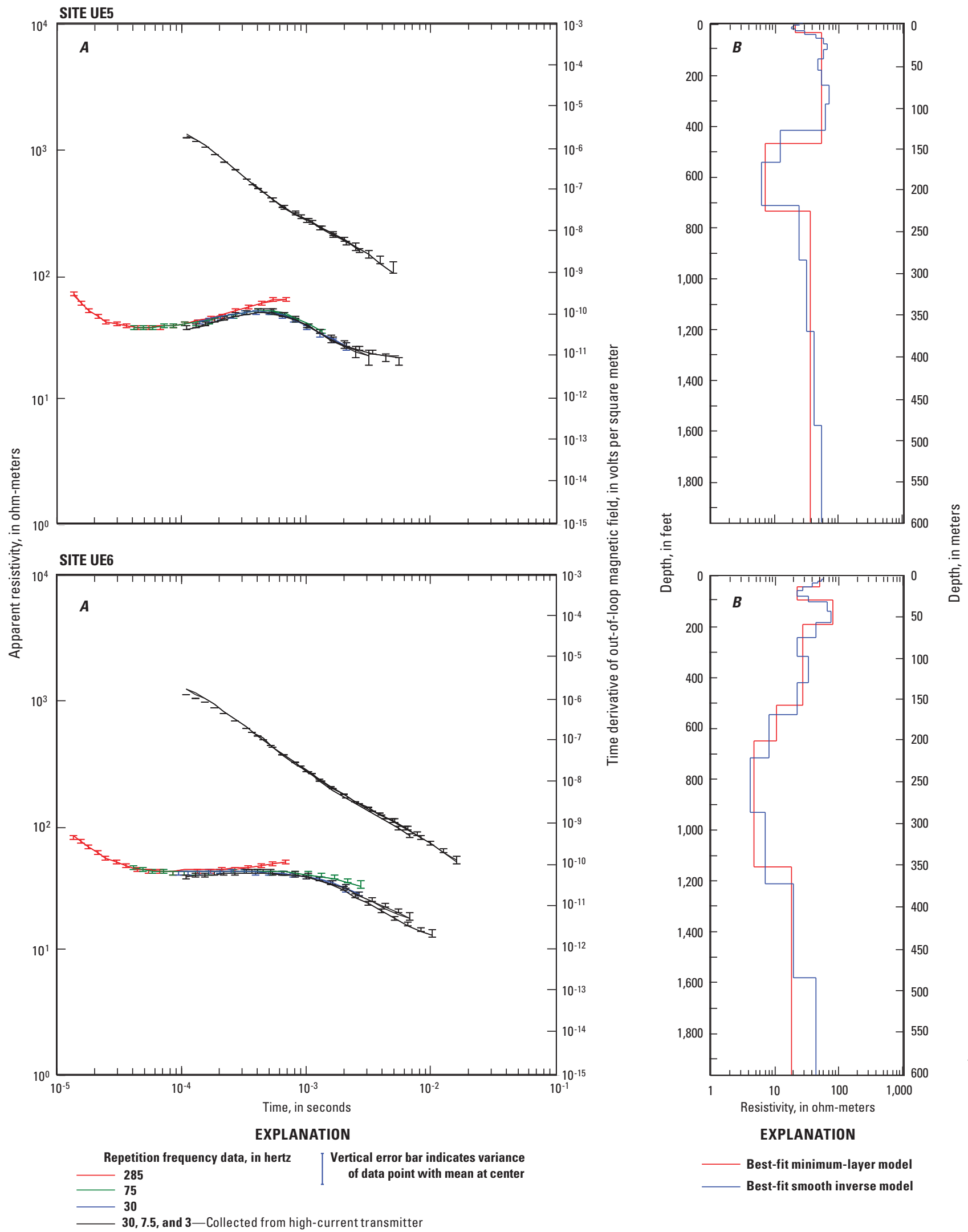

Figure 59. Relations between $A$, central-loop resistivity, out-of-loop vertical magnetic field (upper set of curves time-derivative, right axis), and time elapsed after primary current turnoff; and $B$, depth below land surface and subsurface resistivity modeled from time-domain electromagnetic sounding for sites UE5 and UE6. 
SITE UE7

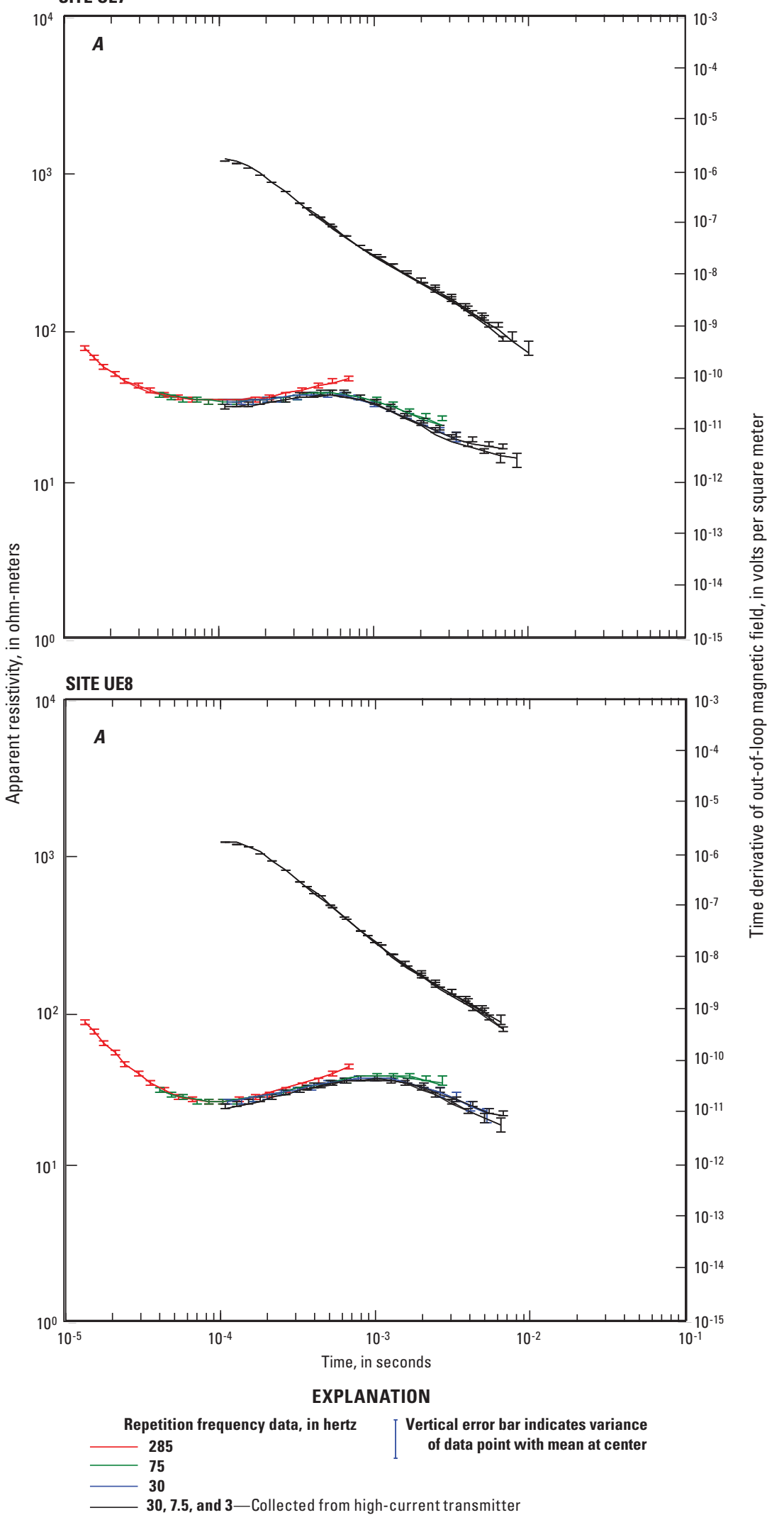

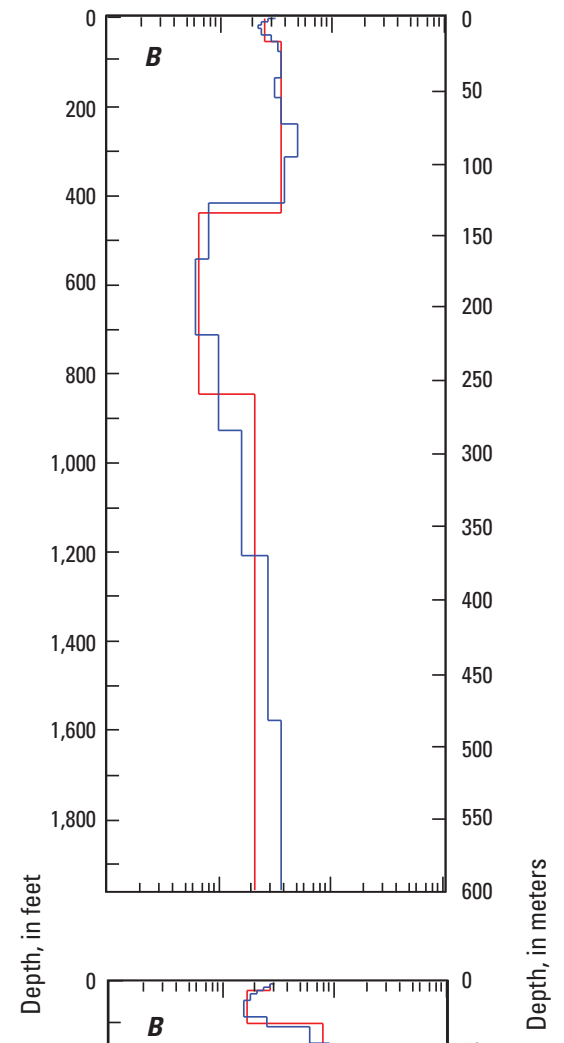

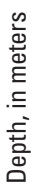

Figure 60. Relations between $A$, central-loop resistivity, out-of-loop vertical magnetic field (upper set of curves time-derivative, right axis), and time elapsed after primary current turnoff; and $B$, depth below land surface and subsurface resistivity modeled from time-domain electromagnetic sounding for sites UE7 and UE8. 

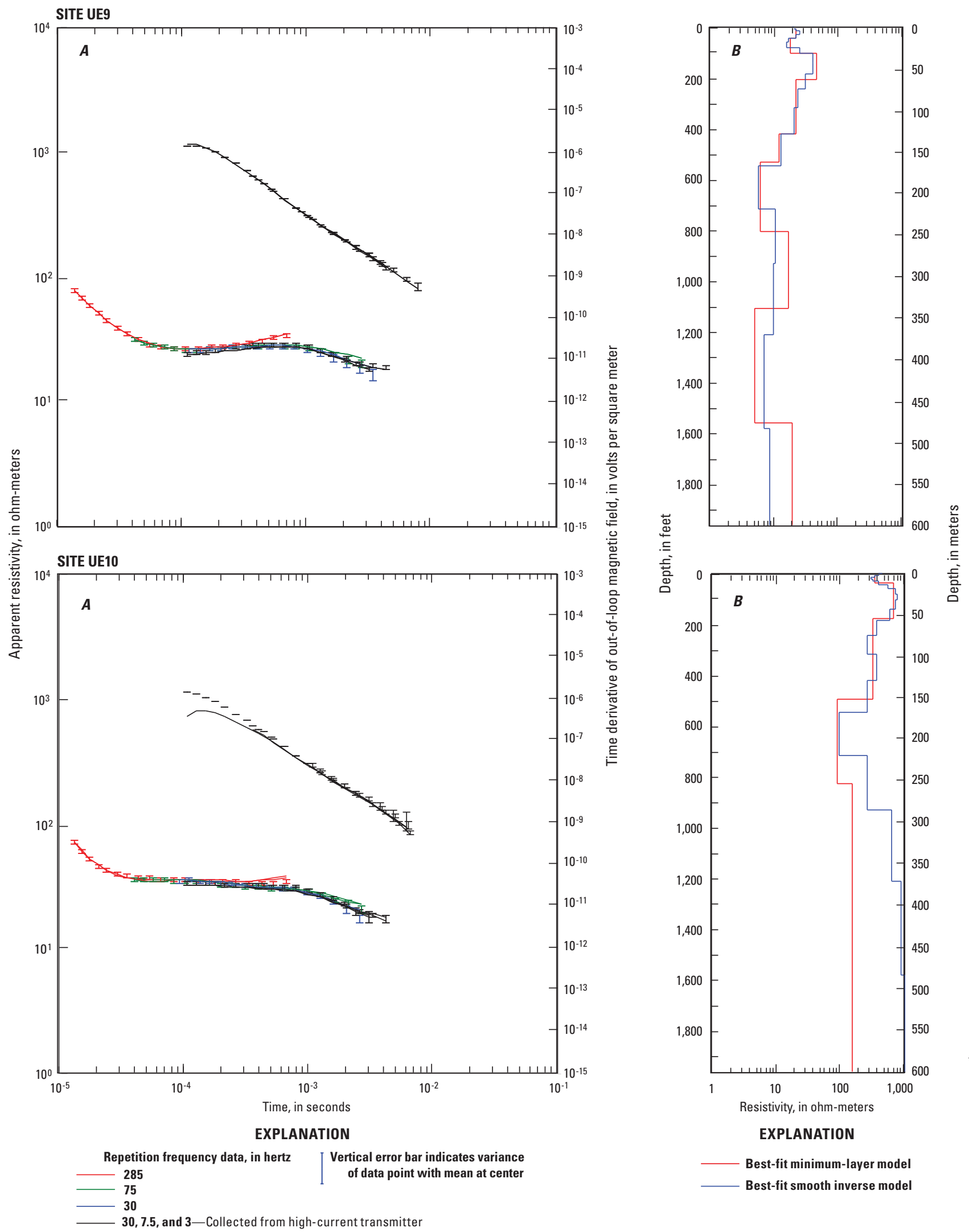

Figure 61. Relations between $A$, central-loop resistivity, out-of-loop vertical magnetic field (upper set of curves time-derivative, right axis), and time elapsed after primary current turnoff; and $B$, depth below land surface and subsurface resistivity modeled from time-domain electromagnetic sounding for sites UE9 and UE10. 
SITE UL1

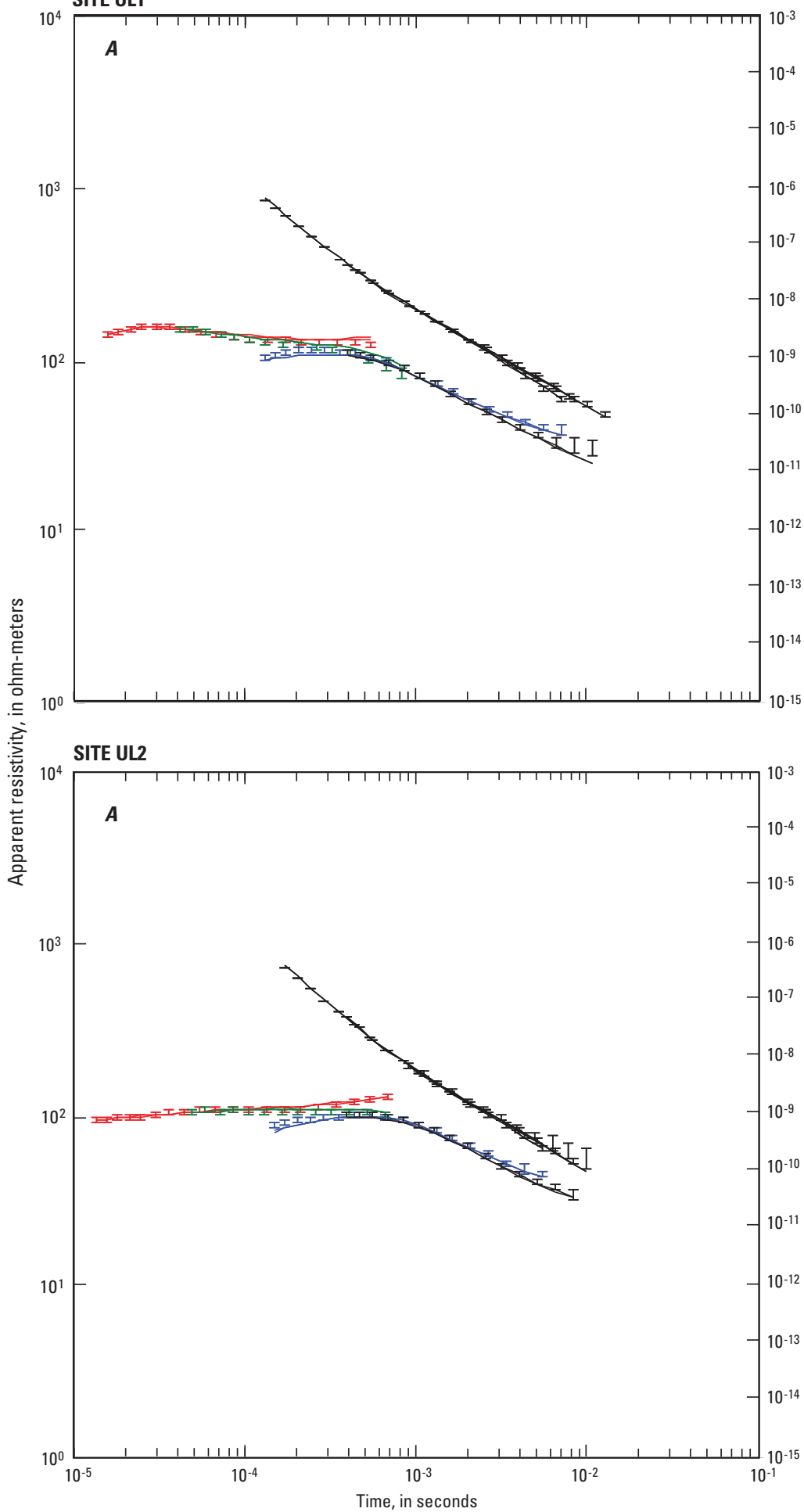

EXPLANATION

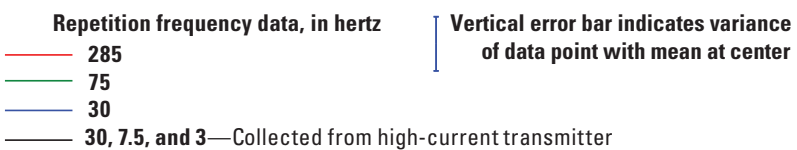

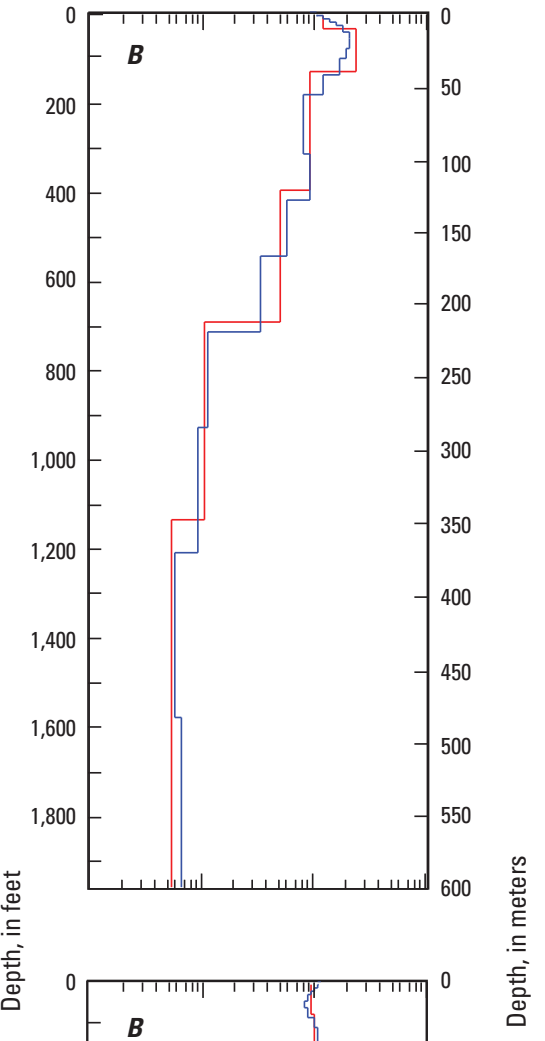

$-50$

$-100$

150

200

250

300

350

400

450

500

550

600

Resistivity, in ohm-meters

EXPLANATION

Best-fit minimum-layer model Best-fit smooth inverse model

Figure 62. Relations between $A$, central-loop resistivity, out-of-loop vertical magnetic field (upper set of curves time-derivative, right axis), and time elapsed after primary current turnoff; and $B$, depth below land surface and subsurface resistivity modeled from time-domain electromagnetic sounding for sites UL1 and UL2. 

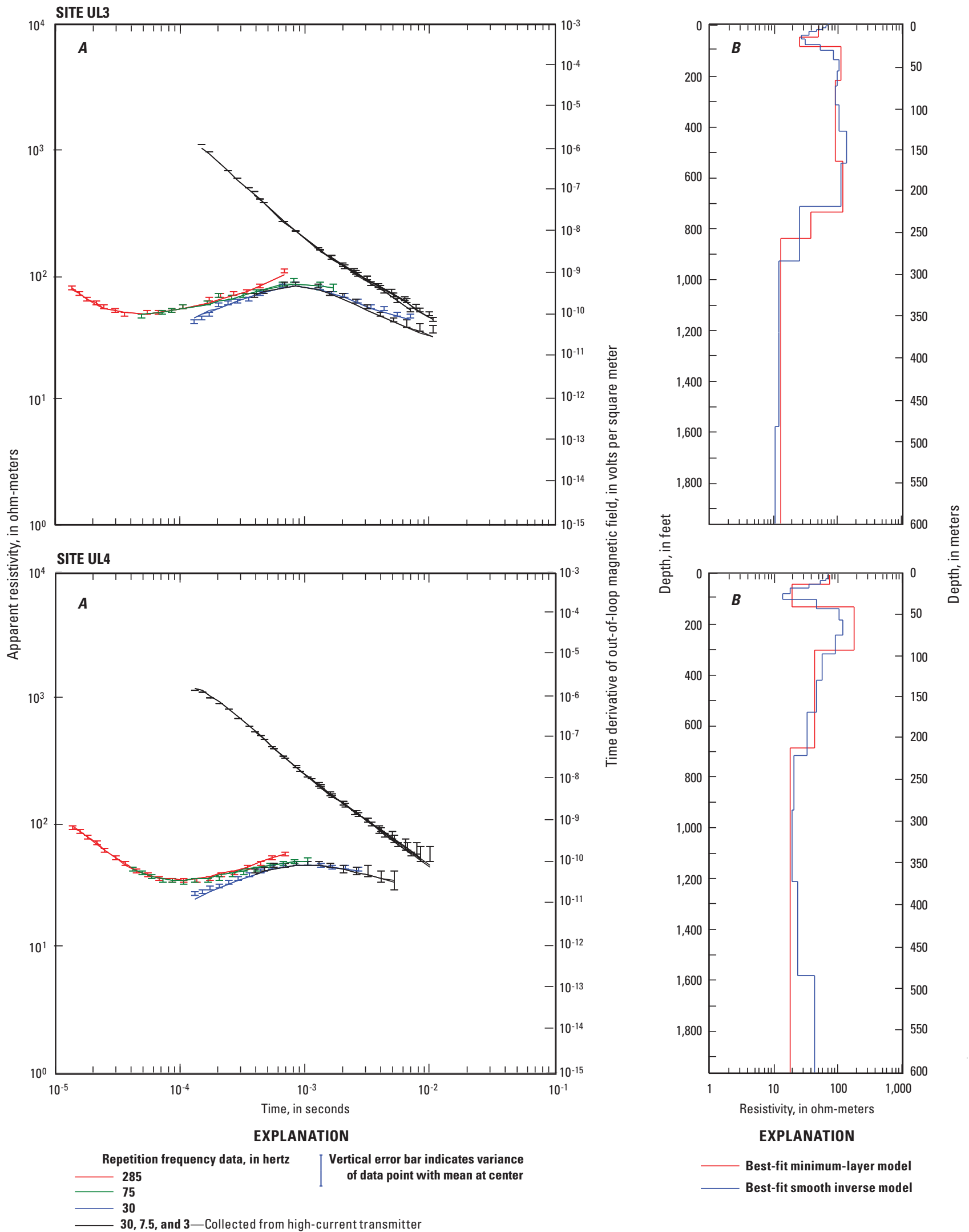

Figure 63. Relations between $A$, central-loop resistivity, out-of-loop vertical magnetic field (upper set of curves time-derivative, right axis), and time elapsed after primary current turnoff; and $B$, depth below land surface and subsurface resistivity modeled from time-domain electromagnetic sounding for sites UL3 and UL4. 


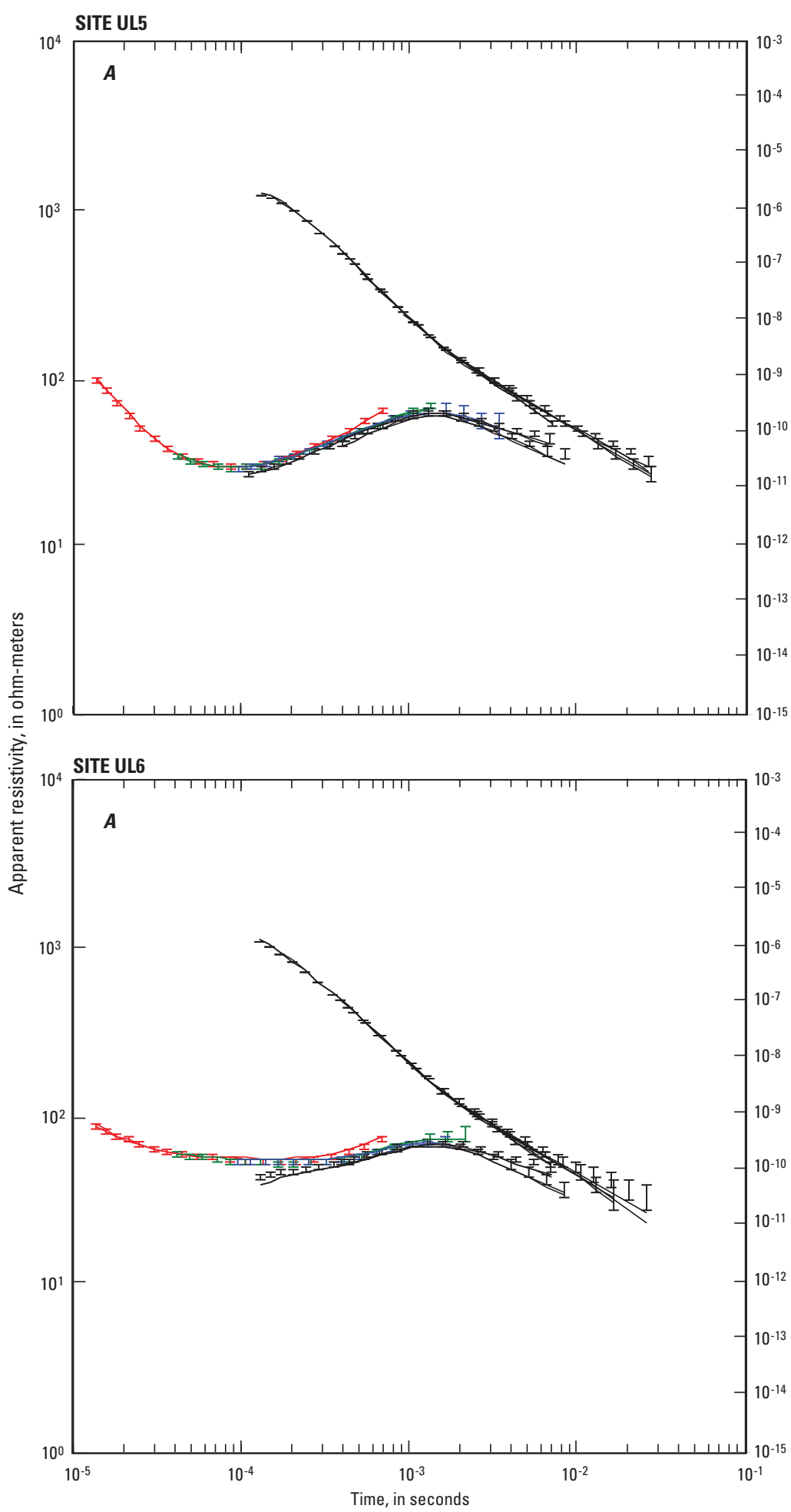

EXPLANATION

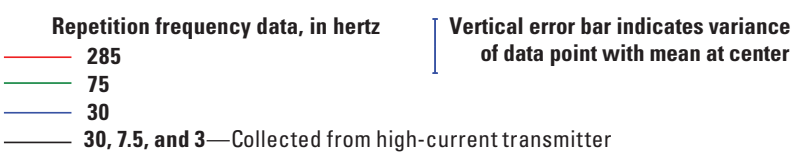

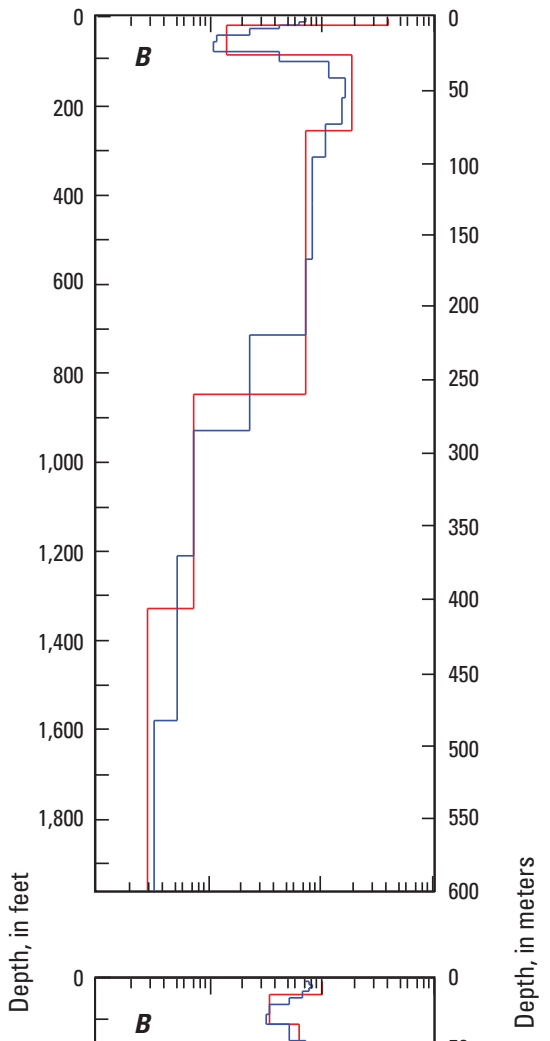

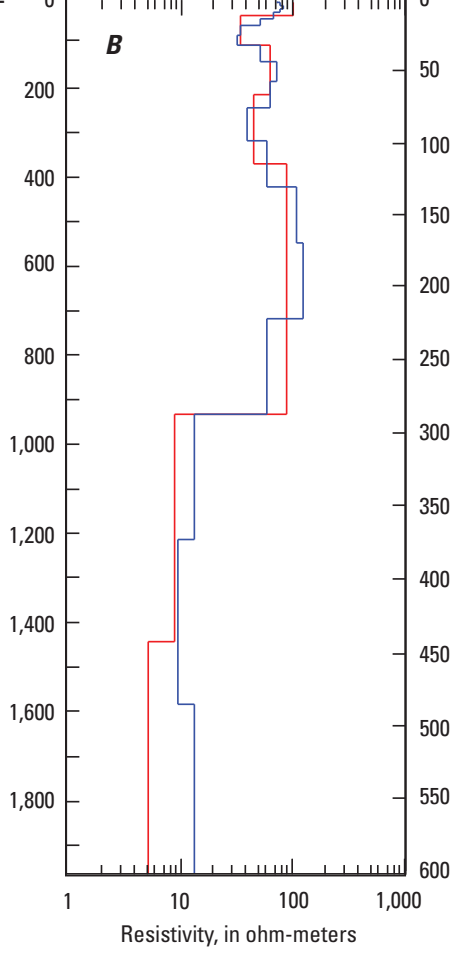

EXPLANATION

- Best-fit minimum-layer model Best-fit smooth inverse model

Figure 64. Relations between $A$, central-loop resistivity, out-of-loop vertical magnetic field (upper set of curves time-derivative, right axis), and time elapsed after primary current turnoff; and $B$, depth below land surface and subsurface resistivity modeled from time-domain electromagnetic sounding for sites UL5 and UL6. 

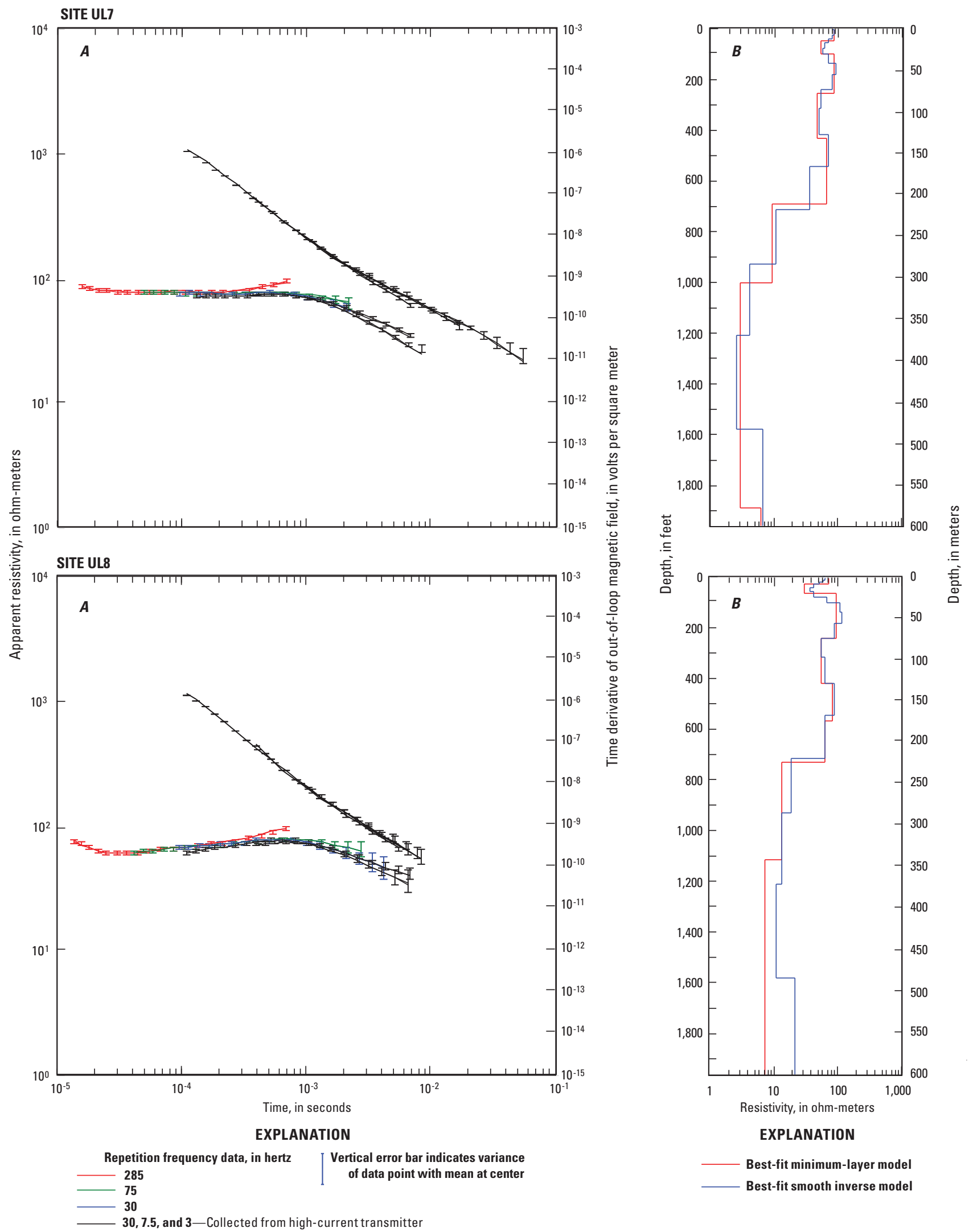

Figure 65. Relations between $A$, central-loop resistivity, out-of-loop vertical magnetic field (upper set of curves time-derivative, right axis), and time elapsed after primary current turnoff; and $B$, depth below land surface and subsurface resistivity modeled from time-domain electromagnetic sounding for sites UL7 and UL8. 

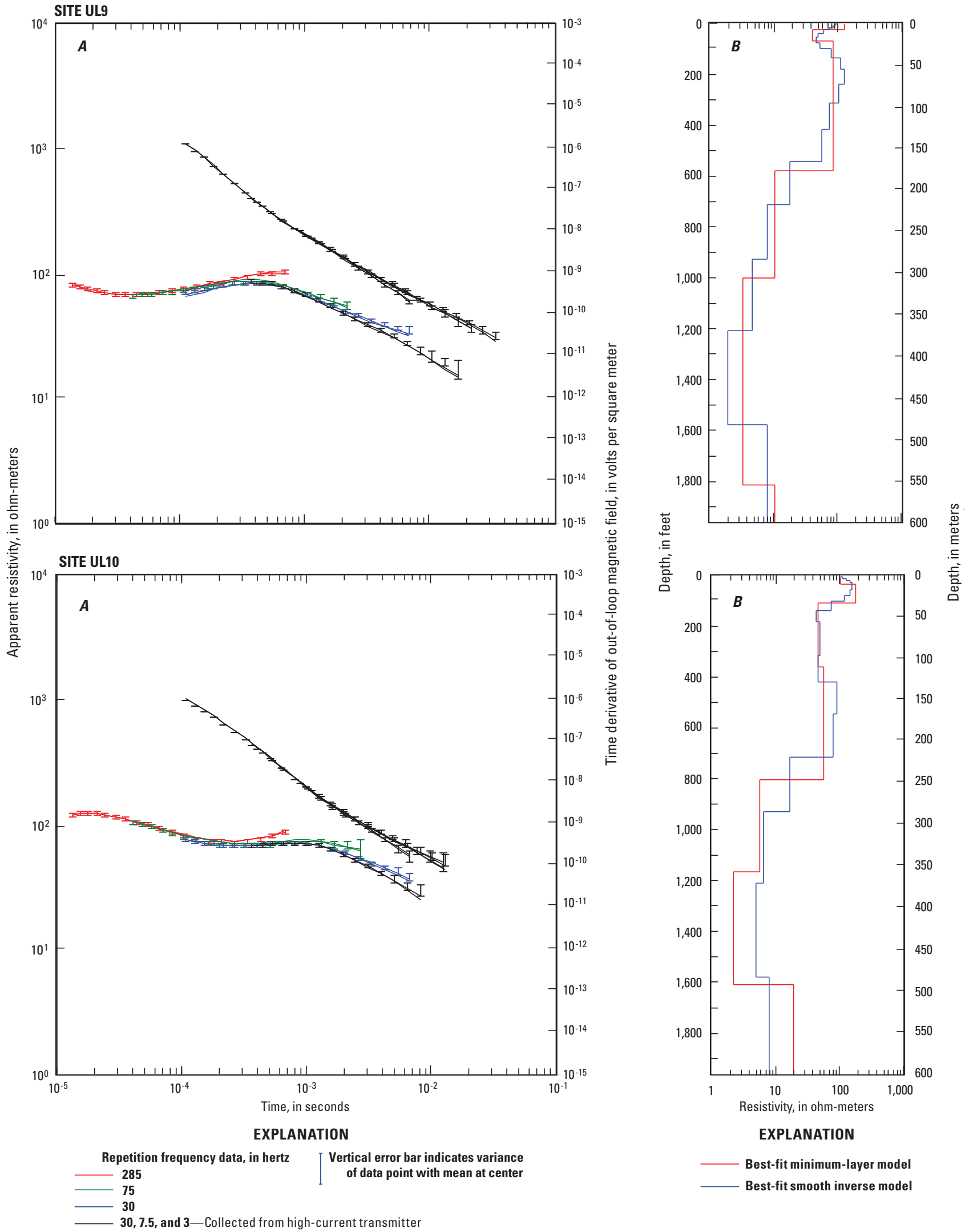

Figure 66. Relations between $A$, central-loop resistivity, out-of-loop vertical magnetic field (upper set of curves time-derivative, right axis), and time elapsed after primary current turnoff; and $B$, depth below land surface and subsurface resistivity modeled from time-domain electromagnetic sounding for sites UL9 and UL10. 

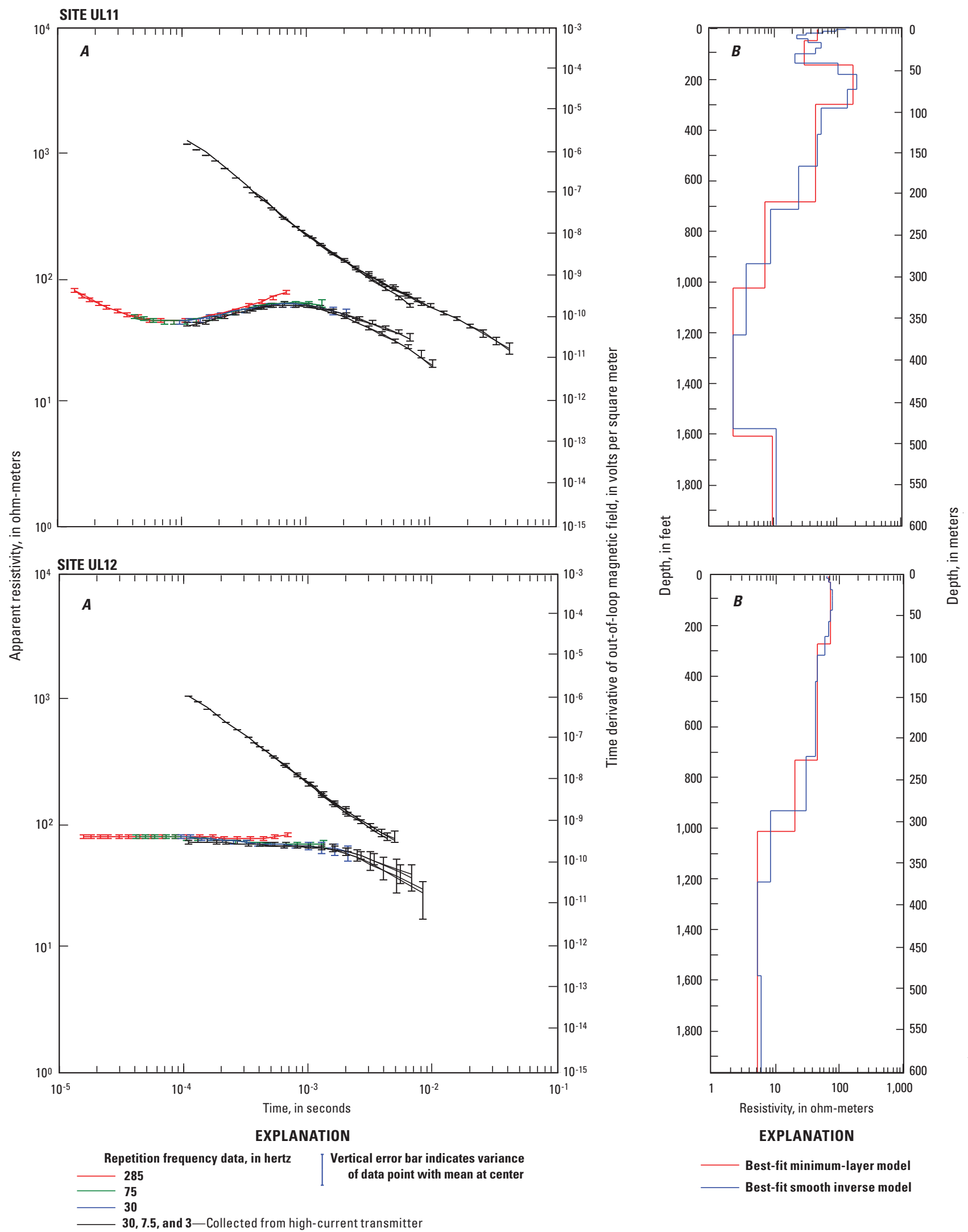

Figure 67. Relations between $A$, central-loop resistivity, out-of-loop vertical magnetic field (upper set of curves time-derivative, right axis), and time elapsed after primary current turnoff; and $B$, depth below land surface and subsurface resistivity modeled from time-domain electromagnetic sounding for sites UL11 and UL12. 

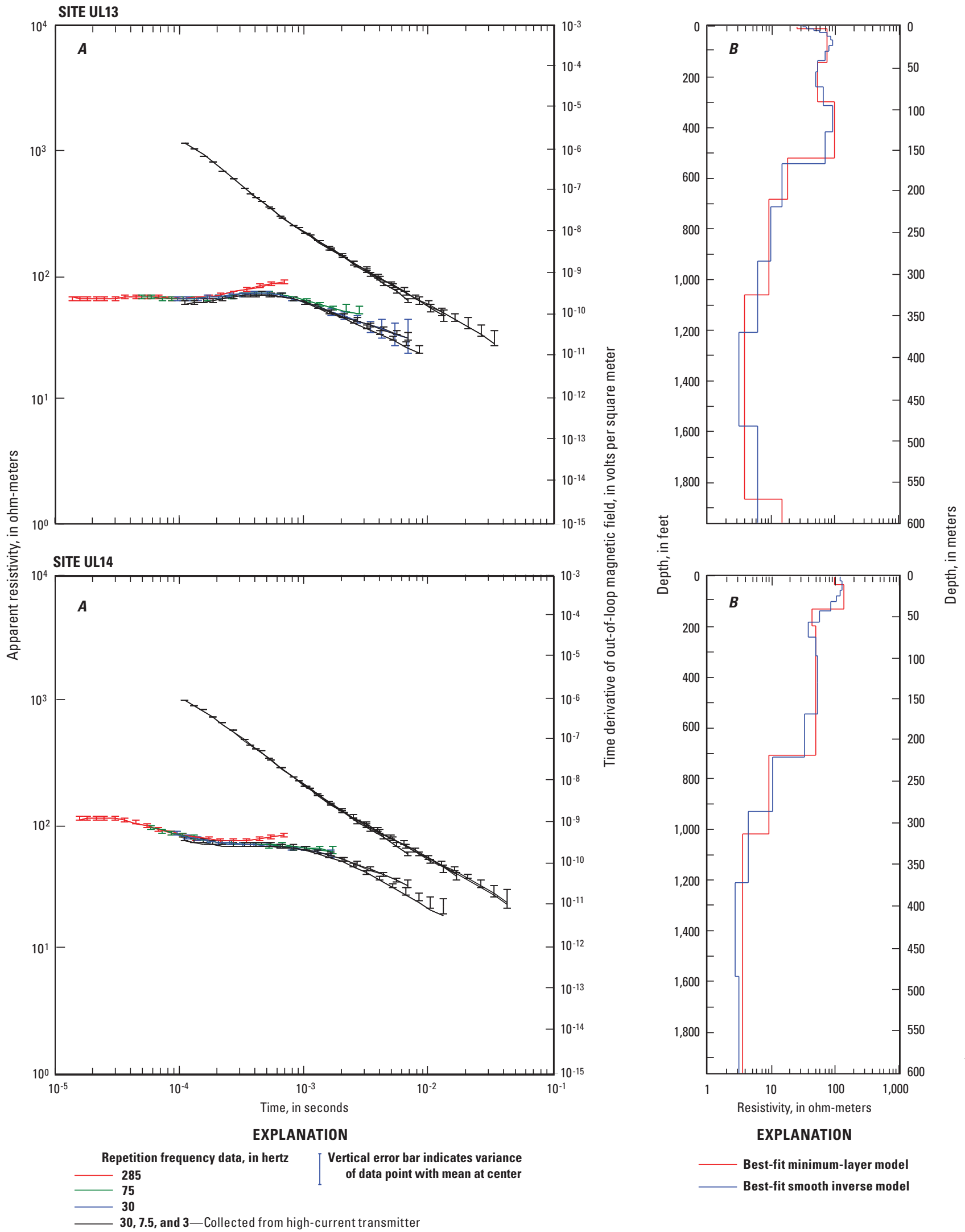

Figure 68. Relations between $A$, central-loop resistivity, out-of-loop vertical magnetic field (upper set of curves time-derivative, right axis), and time elapsed after primary current turnoff; and $B$, depth below land surface and subsurface resistivity modeled from time-domain electromagnetic sounding for sites UL13 and UL14. 

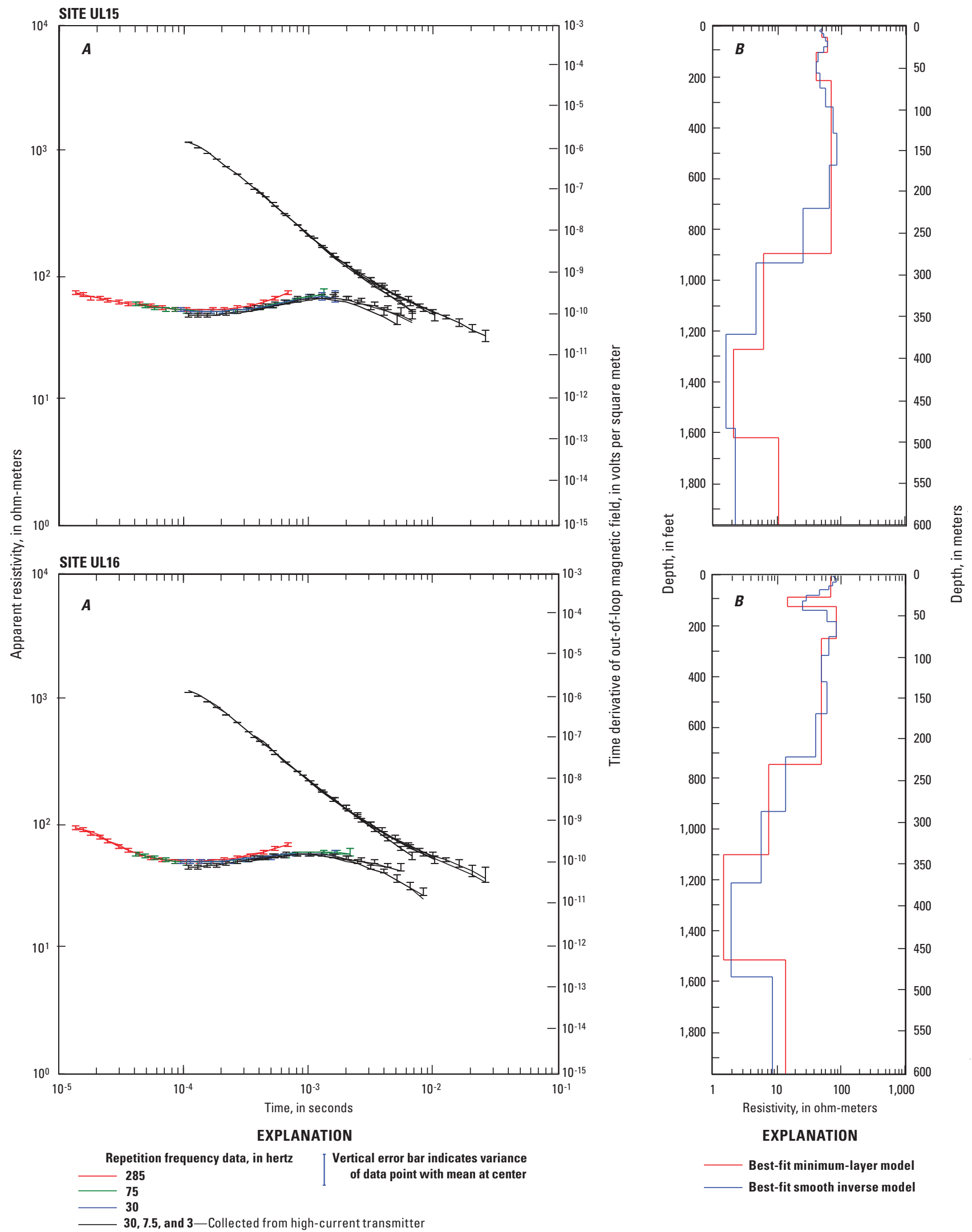

Figure 69. Relations between $A$, central-loop resistivity, out-of-loop vertical magnetic field (upper set of curves time-derivative, right axis), and time elapsed after primary current turnoff; and $B$, depth below land surface and subsurface resistivity modeled from time-domain electromagnetic sounding for sites UL15 and UL16. 

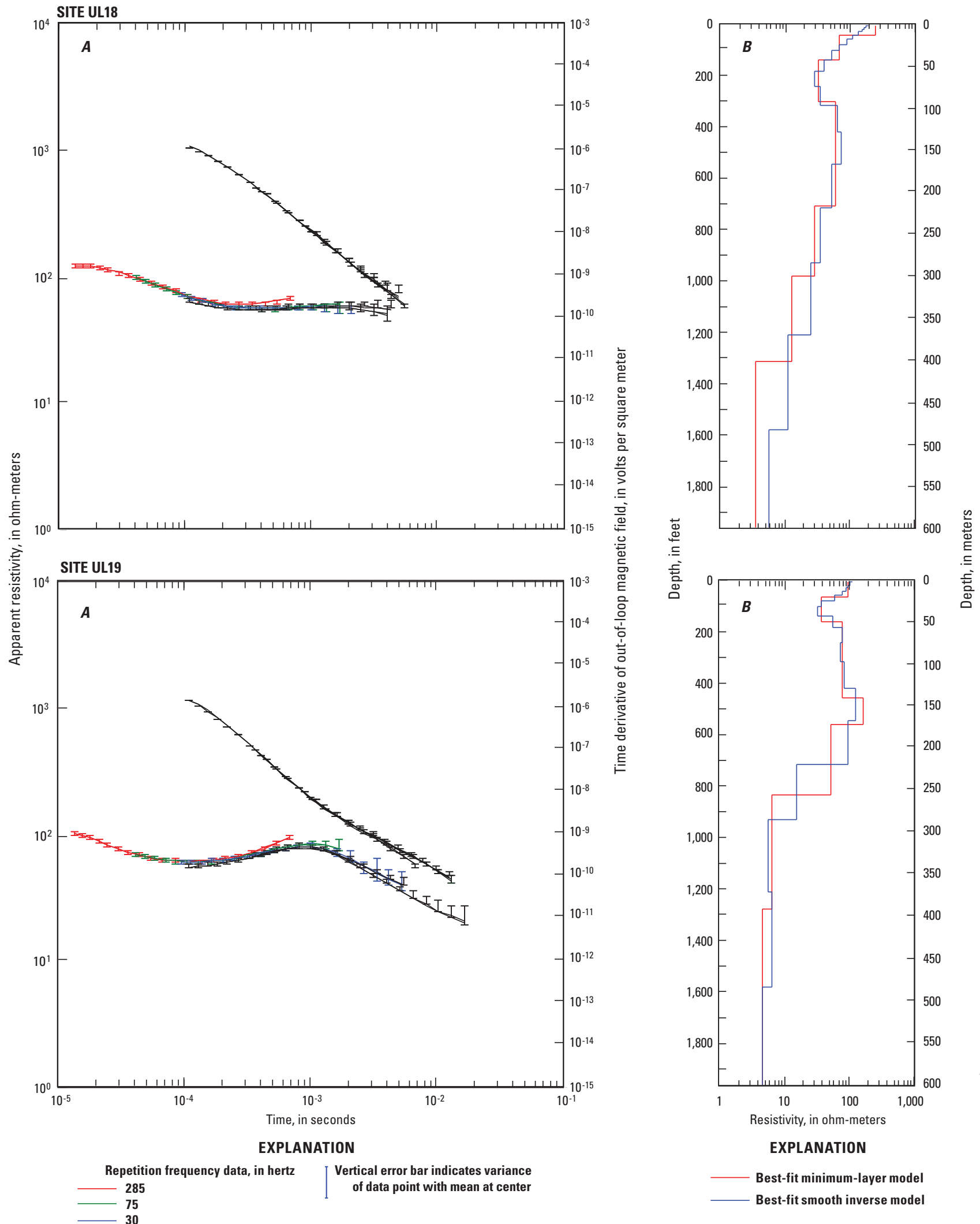

Figure 70. Relations between $A$, central-loop resistivity, out-of-loop vertical magnetic field (upper set of curves time-derivative, right axis), and time elapsed after primary current turnoff; and $B$, depth below land surface and subsurface resistivity modeled from time-domain electromagnetic sounding for sites UL18 and UL19. 
Publishing support provided by: Rolla Publishing Service Center

For more information concerning this publication, contact: Director, USGS Nebraska Water Science Center

5231 South 19th Street

Lincoln, Nebraska 68512

(402) 328-4100

Or visit the Nebraska Water Science Center Web site at: http://ne.water.usgs.gov/ 
Back cover. Photos of test-hole drilling in Custer County, Lower Loup Natural Resources District, 2010. 


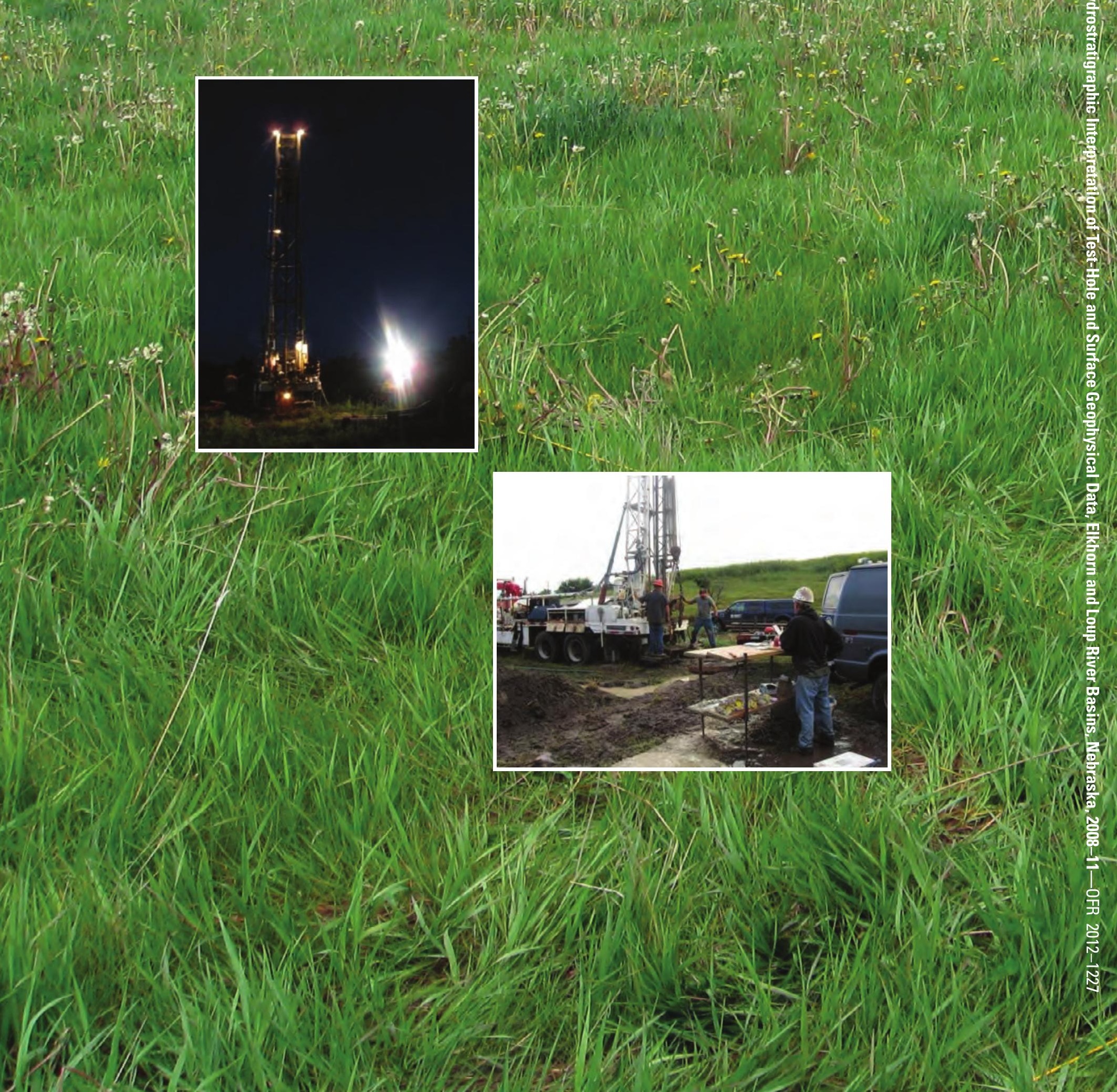

